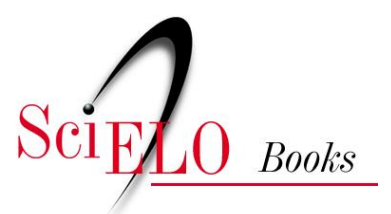

\title{
Tempo de acampamento
}

\author{
Nashieli Rangel Loera
}

LOERA, NR. Tempo de acampamento [online]. São Paulo: Editora UNESP, 2014, 231 p. ISBN 97885-68334-35-5. Available from SciELO Books $<\underline{\text { http://books.scielo.org }>\text {. }}$

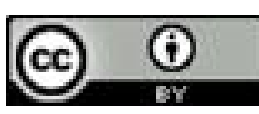

All the contents of this work, except where otherwise noted, is licensed under a Creative Commons Attribution 4.0 International license.

Todo o conteúdo deste trabalho, exceto quando houver ressalva, é publicado sob a licença Creative Commons Atribição $\underline{4.0}$.

Todo el contenido de esta obra, excepto donde se indique lo contrario, está bajo licencia de la licencia Creative Commons $\underline{\text { Reconocimento } 4.0 .}$. 


\section{Tempo \\ DE ACAMPAMENTO}




\title{
FUNDAÇÃO EDITORA DA UNESP
}

\author{
Presidente do Conselho Curador \\ Mário Sérgio Vasconcelos \\ Diretor-Presidente \\ José Castilho Marques Neto \\ Editor-Executivo \\ Jézio Hernani Bomfim Gutierre
}

Superintendente Administrativo e Financeiro

William de Souza Agostinho

Assessores Editoriais

João Luís Ceccantini

Maria Candida Soares Del Masso

Conselho Editorial Acadêmico

Áureo Busetto

Carlos Magno Castelo Branco Fortaleza

Elisabete Maniglia

Henrique Nunes de Oliveira

João Francisco Galera Monico

José Leonardo do Nascimento

Lourenço Chacon Jurado Filho

Maria de Lourdes Ortiz Gandini Baldan

Paula da Cruz Landim

Rogério Rosenfeld

Editores-Assistentes

Anderson Nobara

Jorge Pereira Filho

Leandro Rodrigues 
NASHIELI RANGEL LOERA

\section{TeMPo \\ DE ACAMPAMENTO}


Direitos de publicação reservados à:

Fundação Editora da Unesp (FEU)

\author{
Praça da Sé, 108 \\ 01001-900 - São Paulo - SP \\ Tel.: (0xx11) 3242-7171 \\ Fax: (0xx11) 3242-7172 \\ www.editoraunesp.com.br \\ www.livrariaunesp.com.br \\ feu@editora.unesp.br
}

CIP - BRASIL. Catalogação na publicação

Sindicato Nacional dos Editores de Livros, RJ

\title{
L812t
}

Loera, Nashieli Rangel

Tempo de acampamento / Nashieli Rangel Loera. São Paulo: Edito-

ra Unesp Digital, 2014.

Recurso digital

Formato: epdf

Requisitos do sistema: Adobe Acrobat Reader

Modo de acesso: World Wide Web

ISBN 978-85-68334-35-5 (recurso eletrônico)

1. Antropologia social. 2. Livros eletrônicos. I. Título.

$15-20474$

CDD: 306

CDU: 316.7

Este livro é publicado pelo projeto Edição de Textos de Docentes e Pós-Graduados da UNESP - Pró-Reitoria de Pós-Graduação da UNESP (PROPG) / Fundação Editora da Unesp (FEU)

Editora afiliada:

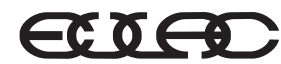

Asociación de Editoriales Universitarias de América Latina y el Caribe

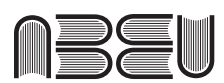

Associação Brasileira de Editoras Universitárias 
a Lygia Sigaud

(in memoriam) 


\section{Agradecimentos}

Em 2002, apenas meses depois da minha chegada ao Brasil, tive a fortuna de conhecer Lygia Sigaud. Naquela ocasião, durante meu primeiro congresso da Associação Brasileira de Antropologia, participei como ouvinte do grupo de trabalho que Lygia coordenava. Foi a partir dali que realizei minhas primeiras incursões à forma acampamento. Encantei-me. A proposta de Lygia era para mim uma novidade. Fui para o campo com aquilo na cabeça. Em 2003 Lygia aceitou participar da minha qualificação de mestrado e a partir desse momento ela se tornou uma interlocutora fundamental e sempre presente nas minhas reflexões. No ano seguinte tive a honra de tê-la na minha defesa de mestrado e, dois anos mais tarde, ela escreveria a orelha do meu primeiro livro. Lygia sempre generosa dedicou longas horas do seu tempo a debater questões de meu trabalho. A última vez que a vi foi no final de 2007, por ocasião da minha qualificação do doutorado, em que mais uma vez Lygia me presenteou com contribuições inestimáveis. Lygia não viu este trabalho terminado, mas seus ensinamentos e uma pequena parte do seu legado estão aqui. Ela foi e sempre será uma grande inspiração. A ela um profundo agradecimento. Este livro é uma modesta homenagem a ela.

Devo agradecer também a presença sempre constante e generosa da minha orientadora do mestrado e do doutorado, Emília 
Pietrafesa de Godoi, que facilitou minha chegada a Campinas e foi a primeira a me acolher na Unicamp. Emília generosamente me cedeu, sempre que precisei, horas preciosas do seu tempo, um bem, hoje em dia, raro no mundo acadêmico. Este trabalho é o fruto desse investimento de tempo e reflexões em conjunto, dialogando, debatendo, questionando. A ela devo muito anos de aprendizado, de carinho e de diálogo frutífero.

A Fernando Lourenço, um excelente sociólogo com alma de antropólogo. Fernando acompanha desde o mestrado meu percurso de pesquisa. E nesse caminho, pude me beneficiar dos seus comentários sempre atinados e pertinentes. A ele "mil gracias" pela leitura sempre minuciosa, cuidadosa e carinhosa do meu trabalho.

Sou imensamente grata a Marcelo Rosa, Mauro Almeida e John Comerford que juntamente com Emília e Fernando avaliaram a tese que dá origem a este livro, muitos dos seus comentários e sugestões estão aqui incorporados.

No decorrer do meu doutorado que deu fruto a este trabalho, tive excelentes professores, dentre eles Mauro Almeida, Omar Ribeiro Thomaz, Suely Kofes, John Monteiro, Heloisa Pontes, Bela F. Bianco, Vanessa Lea, e muito do que aprendi com eles está nestas páginas.

Durante o doutorado, contei com uma bolsa concedida pelo Consejo Nacional de Ciencia y Tecnología do México (CONACYT). Graças a esse suporte, pude me dedicar de maneira integral à pesquisa.

Desde 2010 disponho do auxílio Jovem Pesquisador Fapesp para desenvolver o projeto de pesquisa "Formas de acampamento". Com esse apoio, pude dar continuidade às minhas pesquisas pelo mundo das ocupações de terra.

Agradeço a meus colegas e amigos do Ceres, que durante anos compartilharam minhas descobertas e angústias da pesquisa e sempre propiciaram espaços de discussão.

A meus alunos Elis, Cauê, Murilo e Carla que iniciaram comigo a nova empreitada de pesquisa das "formas de acampamento". Nossos campos "em coletivo" e nossas discussões foram um grande incentivo para retomar o tempo de acampamento. 
Agradeço aos amigos que sempre me fizeram "sentir em casa" e se tornaram parte fundamental da minha vida: Andréia Galvão, Marcos Novelli, Gustavo Rossi, Marília Giesbretch, Eliana e Domingos Creado, Raquel Wiggers, Gabor Basch, Dani Araújo, Chris Tambascia, Verena Sevá e Vilton Costa.

Agradeço especialmente a Gustavo que ao longo da escrita deste trabalho fez uma leitura cuidadosa e debateu comigo questões fundamentais da pesquisa.

Minha mãe, Cecilia, e seus insights de antropóloga autodidata foram maravilhosos para meu trabalho. Ela, muitas vezes, me reconfortou na distância e, muitas outras, acompanhou de perto minhas descobertas e vicissitudes. Na última aventura de trabalho de campo "debaixo da lona preta" contei com sua companhia e, mesmo sob um calor de quase 40 graus, o sorriso permaneceu em seu rosto; cuidou com afinco dos seus netos, e sua alegria pela vida continuou se refletindo a cada minuto.

A meus interlocutores: acampados, assentados, autoridades, dirigentes e militantes do mundo das ocupações de terra que compartilharam comigo segredos, dificuldades, histórias e barracos. Ao longo da pesquisa me dei conta da importância que tinha, para a maioria dos meus interlocutores, conversar com alguém interessado em conhecer suas histórias, aventuras e desventuras. Assim, não só perguntar sobre sua vida e experiência nos acampamentos, mas, principalmente, colocar essas experiências no papel já é uma forma de reconhecimento. É uma forma de tornar visíveis pessoas e circunstâncias da vida que elas consideram importantes e que de outra forma continuariam no anonimato. Vocês fazem uma bela luta!

A meus queridos Cleusa, Alfredo, Edesmaria e seus filhos e netos que me permitiram entrar na vida de vocês, construindo assim vínculos fortes de carinho, amizade e cumplicidade. Este trabalho é também de vocês, é minha pequena homenagem à sua luta.

A publicação deste livro somente se tornou possível graças ao edital PROPG da Unesp, que recentemente me acolheu como professora da casa. 
E finalmente meu agradecimento para mis gueritos: Bertrand, inúmeras vezes me acompanhou ao campo junto com nossos filhos, para que, assim, as saudades não tomassem conta de mim. Sem ele, este trabalho simplesmente não teria sido possível. A Sofia e Gael, que cresceram acompanhando minhas andanças pelo mundo das ocupações de terra, muitas vezes fazendo parte delas, e outras vezes encarando com muita tranquilidade e paciência meu tempo de acampamento. Amo vocês! 


\section{SUMÁRIO}

Lista de siglas 13

Prefácio 15

Introdução: o mundo das ocupações de terra 21

Preâmbulo 31

1 Tempo de barraco 47

2 Tempo de luta 113

3 Tempo de reforma 155

Considerações finais: tempo de acampamento 191 Apêndice 205

Anexos 217

Referências bibliográficas 223 


\section{LISTA DE SIGLAS}

ATST Associação dos Trabalhadores Sem-Terra de São Paulo

GNBB Confederação Nacional dos Bispos do Brasil

CPT Comissão Pastoral da Terra

CUT Central Única de Trabalhadores

Fetag/RJ Federação dos Trabalhadores da Agricultura do Estado do Rio de Janeiro

Fetape Federação dos Trabalhadores na Agricultura de Pernambuco

Fetaemg Federação dos Trabalhadores na Agricultura do Estado de Minas Gerais

Incra Instituto Nacional de Colonização e Reforma Agrária

Mast Movimento dos Agricultores Sem-Terra

MLT Movimento de Luta pela Terra

MNP Movimento Nacional de Produtores

MTL Movimento Terra, Trabalho e Liberdade

MTR Movimento do Trabalhador Rural

MTR Movimentos dos Trabalhadores Rurais 
MTRSB Movimento do Trabalhador Rural Sem-Terra do Brasil

MST Movimento dos Trabalhadores Rurais Sem-Terra

OLG Organização de Luta no Campo

OLPT Organização de Luta pela Terra

PCdoB Partido Comunista do Brasil

PDT Partido Democrático Trabalhista

PRP Partido Republicano Progressista

PR Partido da República

PTB Partido Trabalhista Brasileiro

PT Partido dos Trabalhadores

PSC Partido Social Cristão

PV Partido Verde

Sintraf Sindicato dos Trabalhadores da Agricultura Familiar de Andradina

TSM Acampamento Terra sem Males

Uniterra União dos Trabalhadores Sem-Terra 


\section{Prefácio \\ A SAGA DAS OCUPAÇÕES DE TERRA E SUAS MÚLTIPLAS TEMPORALIDADES}

Tempo de acampamento é o segundo livro de Nashieli Rangel Loera a tratar da experiência de homens e mulheres no "mundo das ocupações de terra"; um mundo com sua gramática própria e suas temporalidades. ${ }^{1}$ Nashieli Loera vai conduzindo o leitor através do mundo das ocupações de terra desfiando as meadas do tempo vivido por seus interlocutores em campo. Mas, de fato, o leitor se sente conduzido não somente pela autora, mas por Edesmaria, Cleusa, Alfredo e seus filhos, pelos membros das famílias Reis e Cerqueira, pois é acompanhando a trajetória dessas duas famílias, como opção metodológica, que Nashieli vai adentrar nesse mundo e seus tempos.

Tempo de acampamento, como nativamente homens e mulheres conceituam a sua vivência, envolve múltiplas temporalidades também percebidas e conceituadas nativamente como tempo de barraco, tempo de luta e tempo de reforma. Partir das categorias nativas e levá-las a sério para acessar o significado que homens e mulheres conferem às suas próprias experiências neste mundo, é uma escolha muito acertada e uma lição de antropologia.

1 O primeiro livro ao qual me refiro é A espiral das ocupações de terra. São Paulo. Campinas: Polis: Ceres, Unicamp, 2006. 
Nashieli acompanha muitos dos seus interlocutores no período compreendido entre 2002 e 2009, desde os seus primeiros acampamentos, passando pelo assentamento - a entrada na terra - de alguns membros das famílias Reis e Cerqueira no final de 2005. Ao final do seu trabalho de campo, muitos dos seus interlocutores ainda continuavam a vida peregrina pelos acampamentos de sem-terra. Uma das primeiras questões postas pela autora é sobre o que leva homens e mulheres a ingressarem no mundo das ocupações. É certo que o desejo e o projeto de "pegar um pedaço de terra" é um dos motivos, mas essa não é toda a resposta. O desejo de "manter os filhos junto deles e principalmente de tirá-los da violência da cidade", e para muitos a busca de um novo sentido para a vida esgarçada e a possibilidade de reconstruí-la, é o que os leva a passar um tempo sempre incerto no mundo das ocupações. Um tempo que pode ir de meses a anos. O que leva muitos dos acampados entre as várias mudanças de acampamentos a "voltarem para a cidade" cansados como dizem "de tanto sofrimento, de tanto acampamento", mas também a retornar, ao final de poucos meses, na busca de uma existência mais digna que vislumbram com a conquista de um lote de terra livres das incertezas de um trabalho precário nas periferias das grandes cidades. Assim como as trajetórias de indivíduos e famílias não são lineares, o tempo vivido, compreendido e expresso por eles através de categorias específicas também não é. Na contabilidade do Tempo de acampamento entram o sofrimento, as perdas, as obrigações cumpridas e outros fatores que escapam a uma medida cronológica. É um cálculo complexo e que se faz mediado pelas relações que vinculam as pessoas no mundo das ocupações.

A autora, contando com os próprios acampados a vida nos acampamentos, vai mostrando a sua complexidade e a multiplicidade e heterogeneidade dos grupos neles existentes. São "andorinhas, moradores, apoios, acampados, militantes, militantes dos acampamentos, dirigentes, velhos acampados, novos e novatos". Atentem que todas essas são categorias próprias do mundo das ocupações e remetem à existência de "grupos de diferenciação e de status", como mostra a autora, que, por sua vez, "vivenciam e 
significam de maneira diferenciada seu tempo de acampamento". Esse universo torna-se ainda mais complexo, quando um mesmo acampamento se fissiona entre vários movimentos. Para comentar somente um dos casos observados, um acampamento com pouco mais de 170 famílias se dividiu em três movimentos - MST, MTR e Sintraf - com diferentes regras, organização e formas de atuação. Se existe uma "forma acampamento", como quer Sigaud (2000), essas fissões vêm evidenciar que há variações nessa forma, como nos mostra a pesquisa que sustenta este livro. Essas variações vão incidir sobre a organização do acampamento e as obrigações dos acampados, dentre outros aspectos, isso quer dizer que incide também no Tempo de acampamento.

A autora faz uma bela e eloquente análise do Tempo de barraco, e como ela mesma mostrou no seu primeiro livro A espiral das ocupações de terra (2006) "o tempo passado debaixo da lona faz parte da lógica do merecimento associada a um discurso do sofrimento", que legitima a pretensão a um lote de terra. $\mathrm{O}$ barraco objetiva esse tempo de acampamento porque o inscreve no espaço.

No Tempo de barraco vemos o tempo se espacializar e o espaço se temporalizar. Essa temporalidade do barraco entra na contabilidade do Tempo de acampamento, que ganha novos significados e duração. Nashieli Loera fala-nos de um acampamento instalado na beira da estrada há mais de seis anos, e conta-nos que havia acampados que literalmente tinham montado "uma casa no barraco, com móveis, jardim, sacada, garagem, e o acampado era identificado como morador, mas, principalmente, como alguém que tinha tempo de acampamento ou tempo de barraco. E uma outra acampada conta orgulhosa "o quanto ela se dedicava a seu barraco, o que incluía a varanda, a área, sua horta e seu quintal”. Para falar do tempo objetivado no barraco, além de trazer uma descrição detalhada, Nashieli Loera traz um registro fotográfico muito eloquente, que nos diz que o Tempo de barraco reporta não somente ao barraco, mas também aos "espaços ao redor dele [...]: a área, a varanda, o quintal, o curral, o galinheiro, a horta". O leitor tem na leitura desse Tempo uma belíssima etnografia do barraco, mostrando que o mundo da lona preta não é nada homogêneo, como um olhar rápido pode sugerir. 
Se o Tempo de barraco objetiva e legitima a pretensão a uma terra, ele não é suficiente, e como mostra-nos Nashieli Loera é preciso ter Tempo de luta: "participação nas marchas, ocupações, passeatas, congressos, entre outros eventos e performances coletivas organizadas pelo movimento". Mas não é só o número que conta nessa complexa contabilidade, mas também as "dificuldades, os recursos mobilizados - nas correrias, que consiste na busca por recursos geralmente feita nas cidades - e os recursos investidos". Como nos mostra a autora com muita perspicácia analítica, "acredita-se que aqueles que arriscaram mais e passam mais dificuldade, de alguma forma acabam acumulando mais tempo de luta". Por fim, o tempo de reforma como expressão de uma temporalidade vivenciada "na maioria das vezes, por velhos assentados" é também uma "categoria utilizada por militantes dos movimentos [...] como uma forma de relembrar as obrigações para com o movimento" cumpridas sobretudo com a participação em novos acampamentos. Já em A espiral das ocupações de terra (2006), a autora havia mostrado que a saga dos acampados não termina com o assentamento, pois "quando uma pessoa ou uma família é assentada, muitas vezes se inicia uma cadeia de compromissos e lealdades para com o movimento que possibilitou a obtenção de um lote de terra". Assim, o tempo de reforma, de alguma maneira abarca todos os outros tempos se se considerar que a primeira ocupação de terras "é o ponto de partida do tempo de reforma" vivido e significado, como nos mostra a autora.

O Tempo de acampamento não é, pois, vivido de forma homogênea por todos os participantes do mundo das ocupações de terra e vai variar, conforme sofrimento, investimento, perdas, condição e posição das pessoas. No mundo das ocupações de terra é o tempo de barraco, de luta, enfim, de acampamento, que leva as pessoas a "entrar na terra", pois legitima e confere reconhecimento a esta pretensão, mas, além disso, como em qualquer mundo social, também no mundo das ocupações de terra, o tempo permite, como mostra Nashieli Loera com muita densidade analítica, o acesso a "bens preciosos como nome, reconhecimento, prestígio, visibilidade, status com ação sobre este mundo". 
Nestas considerações feitas à guisa de apresentação ao livro de Nashieli Loera, penso que merece ainda uma consideração quanto ao uso da expressão "mundo das ocupações de terra". Ao lançar mão dessa expressão, isto é, ao falar de "mundo", a autora está insistindo que a existência e a dinâmica das ocupações de terra não podem ser explicadas por "vontades individuais", apenas por incitações de lideranças, mas está remetendo o leitor a um universo feito de relações em um contexto e em circunstâncias sociais determinadas, que ela vai examinar com acuidade.

Por fim, não é demais lembrar que embora há mais de duas décadas a ocupação com acampamento seja a linguagem adequada, pela eloquência e inteligibilidade que tem para as partes, de demandar terras, ou como preferem muitos autores, de demandar reforma agrária ao Estado, os acampamentos têm sido pouco estudados. O que encontramos mais frequentemente são estudos sobre assentamentos e sobre as organizações que promovem as ocupações como o MST (Movimento dos Trabalhadores Rurais Sem-Terra), Movimento dos Agricultores Sem-Terra (Mast), Movimento do Trabalhador Rural Sem-Terra do Brasil (MTRSB), Movimento Terra, Trabalho e Liberdade (MTL), Movimento do Trabalhador Rural (MTR), Movimento de Luta pela Terra (MLT), e as federações de trabalhadores rurais estaduais, dentre outras. Contudo, não só da escassez dos estudos sobre acampamentos resulta a importância desta publicação, mas, sobretudo, do fato de trazer uma análise fina e sensível que dá ao/à leitor/a o acesso aos significados que este mundo das ocupações de terra tem para os homens e as mulheres que o fazem - aspecto este de interesse para um público mais amplo e não só para os estudiosos do tema. E ainda, ao desenovelar a tessitura de relações sociais que constituem o Tempo de acampamento, Nashieli Loera traz contribuições importantes e indispensáveis para os estudiosos preocupados em entender a dinâmica e os mecanismos sociais das ocupações de terra no Brasil. 


\section{INTRODUÇÃO: \\ O MUNDO DAS OCUPAÇÕES DE TERRA}

Desde o final da década de 1980, no Brasil, começaram a surgir pesquisas sobre os assentamentos da reforma agrária. ${ }^{1}$ Naquela época o modelo de assentamento derivado da desapropriação por ocupações massivas de terra era recente. Os resultados desses estudos nos fornecem dados de extrema importância, que tomam como ponto de partida a organização dos assentados, ou tratam das vantagens ou das desvantagens do modelo assentamento, dos impactos socioeconômicos, da organização social e das relações de poder e conflitos entre os assentados, dentre eles Rapchan, 1993; Lechat, 1993; Medeiros et al., 1994; Bergamasco, 1996; Ferrante, 1999; e ainda estudos mais recentes, como Feix, 2001; Caume, 2002; Bergamasco, 2003; Bergamasco et al., 2003; Martins, 2003; Sparovek, 2003; Leite et al., 2004, entre outros. No entanto, a maioria desses estudos não descreve os processos de formação dos assentamentos, ou seja, as etapas que os precederam: as ocupações e os acampamentos. ${ }^{2}$

1 Na literatura nacional em ciências sociais sobre o tema, assentamento é o nome genérico dado às novas unidades de produção agrícola criadas pelo Estado em benefício dos demandantes de terra.

2 Dos trabalhos anteriormente citados, somente no de Caume (2002) se descreve de maneira detalhada o processo de formação dos acampamentos e a organização social dos acampados que derivaram nos assentamentos por ele estudados no Rio Grande do Sul e em Goiás. 
As ocupações de terra com montagem de acampamentos organizados e mediados pelos chamados movimentos constituem um fato recente na história da luta pela terra no Brasil. ${ }^{3}$ Desde os anos 1990, a fórmula ocupação-acampamento se tornou uma das formas "adequadas" de demandar reforma agrária ao Estado brasileiro, ou seja, para que as demandas das organizações de trabalhadores rurais (movimentos) sejam atendidas, deve existir ocupação e, sobretudo, um acampamento (Rosa, 2009a). ${ }^{4}$ Aqueles que desejam um pedaço de terra devem então ocupar a terra, montar um acampamento organizado por um movimento e, a partir desse momento, fazer suas demandas ao Estado. ${ }^{5}$

3 Movimento é o termo usado por representantes do Estado, por dirigentes das organizações de trabalhadores rurais e pelos próprios trabalhadores que participam dos acampamentos, para se referirem às organizações que promovem as ocupações. Outros termos e frases nativos apareceram também em itálico.

4 Essa forma de demanda ao Estado e a relação entre ocupações de terra e organizações de trabalhadores rurais é o que Rosa (2009a) chama de a "forma movimento".

5 De maneira geral, as principais etapas do processo de reforma agrária ligado à montagem dos acampamentos são as seguintes: uma vez que uma propriedade foi ocupada e um acampamento foi montado, o Instituto Nacional de Colonização e Reforma Agrária (Incra), órgão do governo federal encarregado das desapropriações de terras, classifica a terra ocupada como uma "área de conflito” e inicia-se o processo de vistoria, isto é, a propriedade ocupada é examinada por técnicos do Incra que avaliam a produtividade da terra de acordo com um nível mínimo de rendimento por hectare. Caso a terra seja improdutiva, o valor dela é avaliado e o resultado é encaminhado ao Incra em Brasília, para que o decreto de desapropriação seja assinado pelo presidente. Uma vez que o decreto é assinado, a terra pode ser liberada para assentamento. Esse processo geralmente demora vários anos, não só porque o proprietário da terra ocupada pode pedir a reintegração de posse e os ocupantes acabam, na maioria das vezes, saindo da propriedade e reocupando um tempo depois para iniciar outro processo. Mas também porque o próprio processo da vistoria técnica e envio do resultado é demorado. Desde 2001, uma medida provisória (MP n. 2.183) foi baixada pelo governo federal e proíbe que áreas invadidas sejam vistoriadas pelo Incra por dois anos. Para as lideranças dos movimentos que promovem as ocupações, essa medida tem como objetivo frear a empreitada de ocupações e evitar o pipocar de acampamentos. No entanto, os movimentos conseguem em ocasiões "driblar" essa medida, ocupando e montando acampamentos na beira das propriedades e não dentro delas. Para uma discussão mais apurada sobre as mudanças na legislação brasileira sobre o procedimento de distribuição de terras e sua relação com o MST e o Estado, ver Meszaros (2000). 
É somente no final da década de 1990 que começam a surgir algumas referências sobre a dinâmica das ocupações de terra. Um exemplo são os trabalhos publicados por Fernandes (1998 e 1999) e Stédile e Fernandes (1999). Em estudos mais recentes, especialistas em movimentos sociais têm focalizado suas análises nas organizações que promovem as ocupações, de maneira especial o MST (Movimento dos Trabalhadores Rurais Sem-Terra), entre eles estão Fernandes, 2000; Meszaros, 2000; Veltmeyer e Petras, 2002; Navarro, 2002, 2005; Wolford, 2003; Branford e Rocha, 2004; Ondetti, 2006; Giarracca et al., 2006; Baletti et al., 2008; Vergara-Camus, 2009. No entanto, hoje em dia, existem no Brasil inúmeras organizações de trabalhadores rurais que promovem ocupações de terras e organizam "acampamentos de lona preta", entre elas o Movimento dos Trabalhadores Rurais Sem-Terra (MST), Movimento dos Agricultores Sem-Terra (Mast), Associação dos Trabalhadores Sem-Terra de São Paulo (ATST), Movimento do Trabalhador Rural Sem-Terra do Brasil (MTRSB), União dos Trabalhadores Sem-Terra (Uniterra), Organização de Luta no Campo (OLC), Movimento Terra, Trabalho e Liberdade (MTL), Movimento do Trabalhador Rural (MTR), Movimento de Luta pela Terra (MLT), Comissão Pastoral da Terra (CPT) e as federações de trabalhadores rurais estaduais (Fetape, Fetag/RJ, Fetaemg, entre outras) e demais organizações que surgiram ao longo dos últimos anos. Os participantes das ocupações, sem importar a organização que as promoveu, são chamados genericamente sem-terra; de fato, esse termo é, hoje em dia, uma categoria social. ${ }^{6}$

6 Como mostra Rosa (2009b), sem-terra é uma categoria historicamente construída que, porém, não existe enquanto categoria autônoma em relação ao Estado. Surge no Rio Grande do Sul, no contexto do governo Brizola (19591963) com o sentido de orientar políticas de governo para pequenos agricultores, tendo sido apropriada e seu significado modificado depois por movimentos e organizações de trabalhadores rurais. E tendo sido o MST o movimento que "consagrou a categoria social 'sem-terra' como uma forma social de reconhecimento público” (Rosa, 2009b, p.197). 
São recentes os estudos que tomam as ocupações e os acampamentos como objeto de investigação, privilegiando principalmente o ponto de vista dos homens e das mulheres de carne e osso, que fazem possíveis as ocupações de terras e que vivem o dia a dia dos acampamentos. ${ }^{7}$ Entre eles encontram-se Sigaud 2000, 2002, 2004; L'Estoile e Sigaud, 2006; Sigaud, Rosa e Macedo, 2008; Smircic, 2000; Macedo, 2003, 2005; Rosa, 2004, 2005, 2009, 2011; Loera, 2006, 2009, 2010; Barra, 2007. Esses estudos exploram a diversidade de casos específicos encontrados em diversos lugares do Brasil e formulam hipóteses a respeito das condições sociais que têm contribuído para a reprodução ampliada de um fenômeno social recente: os acampamentos da reforma agrária. ${ }^{8}$

A demanda por reforma agrária, nos últimos 30 anos, tem tomado uma forma social particular, que se distingue das lutas e demandas anteriores. ${ }^{9}$ Como menciona Rosa, "sociologicamente, não é possível estabelecer rupturas entre os acontecimentos passados - como as ligas camponesas e as lutas de posseiros e as atuais ocupações de terra. A diferença está no fato de que, hoje, as ocupações capturam para si um conjunto inédito de símbolos e procedimentos, além de mudanças na forma de reivindicação" (2004, p.74).

Hoje em dia, a forma acampamento, como demonstrado por Sigaud (2000), é uma linguagem social, uma forma de reivindicar demandas sociais ao Estado, políticas públicas, nesse caso, desapropriação de terras para fins de reforma agrária.

7 Na mídia brasileira e por vezes entre funcionários governamentais, as ocupações de terra são tratadas como "invasões"; no meu trabalho privilegio o termo nativo ocupações, usado pelos indivíduos que as realizam.

8 Outros trabalhos nessa direção, que analisam o caso das organizações de piqueteros na Argentina, são Quirós, 2006 e Manzano, 2007; e ainda para um estudo comparativo, recente, sobre movimentos sociais no Brasil e na Argentina, ver Grimberg, Fernández e Rosa (2009).

9 Principalmente a partir da constituição de 1988. Desde então as propriedades que não cumprem com a sua função social podem ser desapropriadas. A partir desse momento, organizações, como o Movimento dos Trabalhadores Rurais Sem-Terra (MST), começam também seu processo de expansão em nível nacional. Para mais detalhes sobre a formação do MST no Brasil, ver Fernandes (2000). 
Segundo Sigaud (2000), a forma acampamento se reproduz instaurando uma espécie de linguagem simbólica. Para os participantes das ocupações, o ato de montar uma barraca num acampamento de sem-terra é a forma de dizer que se é candidato à reforma agrária, e, para os sem-terra em geral, o ato de instalar um acampamento é a forma apropriada de dizer que é essa a terra ou o espaço físico que se pretende que seja desapropriado. Para Macedo, os acampamentos constituem-se como uma linguagem social, que têm seus próprios processos de constituição e que variam de acordo com as conjunturas específicas: "possuem as lonas (que cobrem as barracas) e as bandeiras (que indicam a instituição que organiza o acampamento) como principais símbolos e um modelo de organização social próprio, que vem se transformando ao longo do tempo e também comporta variações dessa representação social de caso para caso" (2003, p.5).

Segundo Loera (2006), a forma acampamento é reproduzida em espiral, um acampamento sempre está vinculado a outro em formação ou já formado e este por sua vez se encontra vinculado a um assentamento. Segundo a autora, são os indivíduos, os ocupantes desses espaços, que, cumprindo com uma série de obrigações e compromissos para com o movimento que organiza a ocupação, convidam outros para formarem novos acampamentos e, mais, eles mesmos participam de novas ocupações, mostrando para os novos acampados a tecnologia de montagem e organização da "forma acampamento".

Como demonstram Sigaud, Rosa e Macedo (2008), a sociogênese dessa forma de reivindicação data dos primórdios dos anos 1960, no Rio Grande do Sul, sendo depois socializada e expandida para outros estados do Brasil. Naqueles anos, ainda seguindo o argumento dos autores, a ideia de ocupar para forçar a distribuição de terras já figurava no horizonte dos possíveis e começava a ser forjado um novo tipo de relação entre demandantes de terra e Estado.

No entanto, nos últimos 30 anos, principalmente após a Constituição de 1988, no contexto pós-ditadura militar, a "forma acampamento" como linguagem social sofreu um processo de expansão 
e principalmente de institucionalização. Segundo os autores anteriormente citados, "a linguagem só começou a se esboçar antes de 1964 e pôde-se consolidar a partir da década de 1990, porque houve escuta por parte do Estado brasileiro" (Sigaud et al., 2008, p.136).

A partir desse momento, diversos atores sociais (principalmente organizações de trabalhadores rurais) foram entrando em cena, deu-se outro tipo de intervenção e atuação do Estado, e outros códigos sociais e outros valores pareciam ser compartilhados ao ocupar uma terra.

Hoje em dia, a chamada reforma agrária parece ter novos sentidos: estar na reforma, para aqueles que realizam as ocupações e se instalam em acampamentos, corresponde a participar de uma ocupação e acampar, reivindicando uma terra para si ou para outros.

Contudo, estar acampado ou manter uma barraca em um acampamento e participar das tarefas do movimento que o organiza pode significar também uma chance de ascensão social e de obtenção de outros bens preciosos e inseparáveis entre si: nome, reconhecimento, prestígio, visibilidade, significação social. Conformando-se, assim, no mundo das ocupações de terra, grupos de status (Bourdieu, 1998), isto é, grupos de indivíduos que ocupam posições de prestígio. ${ }^{10}$

Entendo o prestígio - tomando como inspiração as considerações de Elias (2005) - mais como chances de poder, numa hierarquia tensa, de determinada figuração social, através de elementos conversíveis em moeda de troca nas relações de status, e menos como uma qualidade que se porta ou acumula pela reunião de certas qualidades. ${ }^{11}$ Já para Bourdieu, "são os grupos de status que impõem aos que neles desejam participar, além de modelos de com-

10 Bourdieu inspira-se em Weber para mostrar a diferença entre classes e grupos de status, estes últimos seriam "conjuntos de homens definidos por uma certa posição na hierarquia da honra e do prestígio” (1998, p.14), que se estabelecem por critérios de diferenciação e distinção numa determinada estrutura social. Critérios estes determinados por um sistema de valores.

11 Para Elias (2005), uma figuração social é uma formação social de indivíduos, seu tamanho pode variar, pode ser os jogadores de um jogo de cartas, um grupo escolar, um povoado, uma cidade ou uma nação, onde os indivíduos 
portamentos, modelos da modalidade dos comportamentos, ou seja, regras convencionais que definem a maneira justa de executar os modelos" (1998, p.16).

Ainda, ter certo status no mundo das ocupações também passa pelo tempo de acampamento. Essa expressão não é só uma forma de quantificar o tempo que se passa num acampamento, mas também o número de ocupações, acampamentos e mobilizações nos quais já se participou, o quanto já se sofreu, o número de famílias que se conseguiu levar para a terra, e essa expressão também traduz as relações tecidas com outros acampados, com lideranças e militantes dos acampamentos, as alianças e relações estabelecidas com outros movimentos, com representantes do Estado e com políticos locais e, mais, essa expressão diz respeito ao conjunto de relações e ações ligadas ao nível de comprometimento, ao tempo de participação e dedicação ao barraco, ao acampamento e ao movimento e ao cumprimento de certas obrigações.

Nesse sentido, atualmente, a expressão nativa tempo de acampamento é um código social dentro do mundo das ocupações de terra, tendo em vista que, além de uma medida cronológica, é principalmente um demarcador de prestígio, de status, um princípio organizador e ordenador das relações sociais e um dos requisitos para conquistar a terra, tanto para os participantes das ocupações e dos acampamentos como para dirigentes das organizações que promovem as ocupações e para as autoridades encarregadas das desapropriações de terra, conformando assim uma fórmula social entendida e compartilhada por todos aqueles que fazem parte desse mundo social particular, o das ocupações de terra.

Retomo a expressão "fórmula social" inspirada na bela etnografia Tempo de Brasília, de Antonádia Borges (2003). Essa autora

estão ligados uns com os outros por um modo específico de dependências recíprocas e sua reprodução supõe um equilíbrio móbil de tensões. Ver também Federico Neiburg e Leopoldo Waizbort (Orgs.), Norbert Elias. Escritos $\mathcal{E}$ ensaios. Rio de Janeiro: Jorge Zahar, 2006, v. I - Estado, processo, opinião pública. 
descreve certas "fórmulas mágicas" ou equações cunhadas pelo governo, que servem para classificar a quem venderá ou doará suas terras. Cada fórmula, segundo a autora, "apresenta um conjunto de variáveis que se pretendem as mais precisas para calcular o grau de merecimento da população em face dos bens (raros) a ela disponibilizados pelo Estado" (Borges, 2003, p.165). Ainda Borges nos mostra como essas fórmulas "foram destacadas do repertório classificatório nativo para figurar em uma fórmula mágica estatal, tornando-se logo em seguida, categorias legais de referência para a população" (2003, p.165). No caso aqui apresentado, o tempo de acampamento tem se tornado também um mecanismo classificatório para distribuição de terras entre representantes dos órgãos públicos estaduais encarregados das desapropriações. ${ }^{12}$

No entanto, o tempo de acampamento no mundo social das ocupações de terra pode ter diversos significados, todos eles referidos ao contexto, à situação e à condição do indivíduo, assim como às posições que as pessoas ocupam nesse mundo social particular. Assim sendo, ainda que os participantes do mundo das ocupações façam referência às expressões nativas, tempo de barraco, tempo de luta e tempo de reforma, como expressões homônimas ao tempo de acampamento, descrevem, na maioria das vezes, uma diversidade de significados, ações e situações.

Leach (1971), na sua análise da categoria tabu entre os clãs trobriandeses, demonstra que há vários significados de tabu, significados que seriam acidentalmente nomeados com um mesmo termo, no entanto, tabu seria uma categoria de relações e seu significado varia de acordo com o contexto, a idade, o status e a posição genealógica do indivíduo dentro de um sistema de parentesco.

Em nosso caso, a expressão nativa tempo de acampamento traduz distintos significados e principalmente distintas temporalidades vivenciadas por indivíduos que ocupam diversas posições no mundo das ocupações de terra. Contudo, se as palavras, como Malinowski

12 Para uma análise etnográfica deste mecanismo classificatório no caso de um acampamento no estado de São Paulo ver Loera, 2011. 
(2002) nos disse, "têm o poder fatal de engendrar ação", então as expressões anteriores fariam referência também a determinadas situações e práticas sociais. Malinowski ([1965] 2002) na sua "teoria etnográfica da linguagem”, adendo do seu Coral Gardens, nos inspira a analisar os termos dos grupos que estudamos, no seu contexto, em situação. Para esse autor, certas palavras nativas só podem ser definidas quando analisadas em situação. Só assim poderemos saber o que esses termos significam para os nativos. Na proposta dele é imprescindível estudar um mesmo termo num grande número de situações, para elucidar seus significados.

Assim sendo, o tempo de barraco, por exemplo, tanto para os acampados como para lideranças dos movimentos, faz referência ao tempo que de fato uma pessoa passa debaixo da lona preta num acampamento, ${ }^{13}$ mas também para os acampados refere-se à dedicação ao seu barraco e às tarefas do acampamento em geral; os acampados acreditam que a vida no acampamento é sofrida e também se faz referência ao tempo de barraco como uma forma de medida do sofrimento debaixo da lona. Já o tempo de luta é importante para novos e velhos acampados que mantêm barraca principalmente em acampamentos do MST e, sobretudo, para coordenadores e militantes que organizam e dirigem os acampamentos. ${ }^{14}$ Através do tempo de luta se contabiliza a participação em mobilizações ou jornadas organizadas pelo movimento (ocupações, marchas, atos, caminhadas e outras formas de protesto) e também é uma forma de medir a capacidade de mobilização individual e de certos grupos do

13 Ficar debaixo da lona é uma expressão comum entre os participantes dos acampamentos. Muitas vezes é usada em situações nas quais os acampados querem mostrar ou fazer explícitas as penúrias e dificuldades pelas quais passam no acampamento e está relacionada à noção de sofrimento (Loera, 2006 e Loera, 2009b).

14 Como assinalado por Rosa (2009), o termo militante é usado principalmente por indivíduos ligados ao MST e participantes dos acampamentos promovidos por esse movimento. Para outros casos se faz referência a dirigentes ou lideranças. Ocasionalmente também pode ser usado o termo militante para lideranças que não fazem parte dos quadros do MST. Farei referência a esses diferentes termos respeitando então a lógica nativa. 
movimento. E, por último, o tempo de luta também expressa o tempo de dedicação ao movimento e a capacidade de negociação que se tem, assim como o capital de relações acumulado, que pode ser mobilizado em beneficio dos acampados e do movimento.

E finalmente o tempo de reforma é uma expressão utilizada por militantes dos movimentos e, na maioria das vezes, por velhos assentados. O tempo de reforma parece equacionar os dois tempos anteriores como uma forma de relembrar o cumprimento de obrigações para com o movimento, é também uma forma de contabilizar os ganhos e as perdas dessa incursão pelo mundo das ocupações de terra; e finalmente o tempo de reforma também evidencia, dependendo do contexto da situação, a posição que as pessoas ocupam nesse mundo social.

Desse modo, neste trabalho retomo o tempo de acampamento como fio condutor e tento, além de tornar evidentes seus vários significados, descrever como os participantes do mundo das ocupações de terra vivenciam, na prática, esses diversos tempos. 


\section{PreÂmbulo}

Antes de iniciarmos o percurso pelo mundo das ocupações de terra, remeto a alguns contextos, métodos, lugares e pessoas que ajudarão o leitor a compreender as diferentes escolhas, argumentos e hipóteses deste trabalho, assim como a situar as condições sociais de produção da pesquisa.

A estratégia metodológica da pesquisa consistiu em seguir o percurso de uma família extensa, a família Reis-Cerqueira (consanguíneos e afins) desde os primeiros acampamentos nos quais estiveram até - alguns membros da família - serem assentados no final de 2005 e o processo vivido durante quase três anos, já como assentados da reforma agrária. Também acompanhei o percurso de membros dessa família extensa que até começo de 2009 continuavam na peregrinação entre acampamentos de sem-terra.

Através do percurso de uma família pelo mundo das ocupações de terra, meu objetivo é o de mostrar o que esse caminho permite revelar desse mundo social e das suas particularidades; com isso, quero dizer que minha ênfase não está numa história de vida ou numa trajetória individual ou familiar. ${ }^{1}$ Por outro lado, nesse ca-

1 Remeto ao leitor para a existência do item "Interlocutores" em "Apêndice", em que de maneira resumida e em ordem alfabética apresento as pessoas com 
minho, privilegio o ponto de vista dos homens e das mulheres que vivenciam o cotidiano dos acampamentos.

\section{A família extensa Reis-Cerqueira²}

Cleusa e Alfredo dos Reis são casados há mais de 30 anos. Eles se conheceram, como eles gostam de dizer, "na estrada", quando Alfredo era caminhoneiro. Ele, filho único, foi criado na roça, onde ficou até os 23 anos trabalhando na terra do pai, um pequeno produtor do interior do estado de São Paulo. Alfredo saiu da roça para trabalhar numa linha de leite na cidade; dois anos mais tarde dedicou-se à profissão de que ele mais gosta, a de caminhoneiro. Alfredo é viúvo da sua primeira esposa com a qual teve cinco filhos. Ele conheceu Cleusa quando sua esposa ainda era viva, mas já estava bastante doente. Com Cleusa têm três filhos: Tiago, Marcos e Junior.

Cleusa é originária do Recife e filha de pequenos produtores rurais. Também foi criada na roça. Casou-se muito jovem e teve um filho, cuja guarda, depois da separação do seu primeiro marido, foi ganha pela avó paterna. ${ }^{3}$ Cleusa trabalhou como empregada doméstica na cidade do Recife e só saiu de lá quando conheceu Alfredo, que era caminhoneiro e estava de passagem por Recife indo

as quais dialogo ao longo do texto. Mais do que uma pequena biografia de cada uma delas, a ênfase está na posição ou no percurso delas pelo mundo das ocupações de terras. Por outro lado, no texto, adoto duas estratégias com o objetivo de respeitar a vontade de alguns dos meus interlocutores, principalmente de militantes do MST e de autoridades e representantes do governo, de manter sua identidade preservada: 1) usar um termo genérico, dependendo da posição da pessoa como autoridade ou militante, dirigente ou coordenador; ou

2) trocar o nome da pessoa e os nomes de alguns lugares onde foi levado a cabo o trabalho de campo.

2 O percurso dessa família encontra-se indicado no Mapa 1 em "Anexos". Algumas informações acerca da trajetória dos membros dessa família encontram-se em Loera, 2006 e 2010.

3 Cleusa ficou mais de 25 anos sem ter notícias desse filho e foi só em 2008 que o filho conseguiu localizá-la por intermédio de uma vizinha de Sumaré (SP), a cidade onde morava antes de acampar. 
em direção a São Paulo. Cleusa decidiu ir com ele, com a expectativa de conseguir um bom emprego e poder recuperar seu filho. No entanto, como ela me disse, desde então "a gente não se descolou mais”. Depois de morarem em vários lugares do interior de São Paulo e de trabalharem como caseiros, cuidando de um sítio, eles se instalaram para morar numa casa comprada na periferia de Sumaré, município localizado a 100 quilômetros da cidade de São Paulo, onde moravam quando receberam o convite "para ir para a terra". Eles participaram pela primeira vez de uma ocupação de terras em abril de 2002, foram convidados por um conhecido de Sumaré, para irem juntar-se a um contingente de pessoas que se preparava para realizar uma grande ocupação na região de Bragança Paulista (SP). Aquela primeira ocupação deu vida ao acampamento Terra Sem Males (TSM), ${ }^{4}$ organizado pela militância da Regional de Campinas do MST. ${ }^{5}$ Cleusa e Alfredo aceitaram o convite para ir acampar. Um dos motivos mais fortes que os levaram a aceitar esse convite foi não só o desejo de pegar um pedaço de terra, mas de manter os filhos junto deles e principalmente de tirá-los da violência da cidade e do envolvimento com "pessoas que não prestavam".

Em 2002 Cleusa (43) e Alfredo (65) acampavam com Tiago, o filho mais velho, que estava com 18 anos, e Júnior, o caçula de 13 anos. Em abril de 2003, um ano depois, eles já haviam passado por várias ocupações, haviam ficado fora do acampamento durante dois meses e haviam voltado novamente para o TSM, que, depois de ter sofrido alguns despejos, havia sido montado em Cajamar, a 30 quilômetros da cidade de São Paulo, em conjunto com famílias do acampamento Irmã Alberta, organizado pela militância da Regional de São Paulo do MST. ${ }^{6}$ De fato, as famílias do TSM, por iniciativa dos militantes

4 Daqui em diante irei fazer referência a esse acampamento como TSM.

5 Os militantes do MST de São Paulo organizam eventos e mobilizações dos escritórios do movimento montados nas principais cidades desse estado. Escritórios são chamados de Regionais. Os militantes, no entanto, também estão divididos em Direção Nacional, Coordenações Estaduais e Regionais.

6 Para mais detalhes sobre a organização social e montagem desses acampamentos ver Loera, 2006. 
de Campinas, haviam ido ajudar as famílias do acampamento Irmã Alberta, "fazendo a massa", isto é, fazendo número para conseguir criar o efeito desejado de qualquer ocupação, o de uma grande massa de acampados e barracas de lona. Foi em Cajamar que Tiago, filho mais velho de Cleusa e Alfredo, se casou com Tina, uma moça de 19 anos originária da Bahia, que havia chegado para acampar com sua mãe Edesmaria (47) e seu irmão Sino (18). Sino também conheceu a sua esposa no acampamento, Márcia (18). Márcia acampava com os pais, mas eles ficaram pouco tempo acampando e acabaram voltando para a cidade onde moravam antes de ir para o acampamento.

Edesmaria nasceu em Bom Jesus da Lapa (BA), no seio de uma família numerosa. Seu pai dedicava-se à pesca e à agricultura, e sua mãe, também de origem rural, dedicava-se ao trabalho na roça e a cuidar dos filhos. Edes passou sua infância à beira do rio São Francisco, numa pequena comunidade rural localizada no município de Serra do Ramalho, no sertão baiano. Edes, como o resto dos seus irmãos, ajudava seus pais no trabalho da roça. Desde muito cedo aprendeu, como ela diz, "a pegar na enxada". Com 15 anos, Edes saiu da sua comunidade de origem para tentar sorte "na Lapa" (na cidade de Bom Jesus da Lapa). ${ }^{7}$ Ela gosta de dizer que a partir daí ela teve de "se virar sozinha". Ela passou por vários empregos na cidade, inclusive, como ela relata, foi "mulher da vida alegre". Foi nesse momento, no começo dos anos 1980, que nasceu a filha de Edes, Tina. Quando Tina tinha 6 meses de idade, Edes casou-se com um moço que a frequentava e que, nas palavras dela, "a tirou dessa vida”. Seu marido registrou a filha de Edes como dele, e menos de um ano depois nasceu Sino. Desse casamento nasceram mais quatro filhos. Edes mudou-se com sua família e se instalou para morar nas proximidades de Feira de Santana, uma das maiores cidades do estado da Bahia. Foi somente no começo dos anos 1990

7 Edesmaria engravidou aos 15 anos e teve um filho que acabou sendo criado por sua mãe, que na época também estava com um filho recém-nascido. Para Edes, o estatuto de mãe solteira dentro da sua comunidade lhe trouxe algumas dificuldades e, por conselho da sua mãe, acabou saindo da sua comunidade e se instalou em casa de parentes na cidade de Bom Jesus (BA). 
que Edes conheceu o movimento (MST). Sua sogra havia sido convidada para acampar num acampamento recém-montado, próximo à cidade de Feira de Santana. Edes, que a acompanhava, acabou-se envolvendo nas tarefas do movimento, realizando o que ela chama de "trabalho nos acampamentos". No entanto, como será descrito no decorrer do texto, Edes acabou não só saindo do movimento, mas também da Bahia. Edes, vivendo um momento emocional difícil ao se separar do marido, decidiu tentar sorte em São Paulo, levando consigo só dois dos seus filhos, Tina e Sino. Edes morou um tempo em Santo André (SP), na região metropolitana de São Paulo, na casa do seu irmão, e depois foi convidada pela sua irmã para passar um tempo com ela no assentamento onde mora no interior de São Paulo, no município de Sorocaba. Foi nesse momento que se lhe apresentou a oportunidade para acampar no acampamento Terra Sem Males, montado em Cajamar. Assim, em janeiro de 2003 Edes estava novamente entre os sem-terra.

Em julho de 2003, a família extensa Reis-Cerqueira (Cleusa. Alfredo, Junior, Tiago, Tina, Edesmaria, Sino e Márcia) saiu de Cajamar, em um ônibus fretado pelo movimento, com outras 50 famílias do acampamento. A promessa que havia circulado entre militantes e acampados por ocasião da mudança era que os acampados que saíssem do TSM, naquele ônibus, seriam assentados na região de Araçatuba, onde ganhariam aproximadamente 6 alqueires de terra para cada família. Assim, percorreram mais de 600 quilômetros para se instalar em outro acampamento, o Dom Hélder Câmara, que montaram no município de Birigui no noroeste do estado de São Paulo.

Do Dom Hélder Câmara, eles passaram por mais dois acampamentos naquela região, um organizado por lideranças vinculadas à Central Única dos Trabalhadores (CUT) e outro organizado pelo MST. Entre essas mudanças de acampamentos, que durou quase dois anos, Cleusa, Alfredo, seus filhos e Tina, sua nora, "voltaram para a cidade" ou, como eles costumam dizer, "cansaram de tanto sofrimento", "de tanto acampamento" e se instalaram na periferia de uma pequena cidade localizada a poucos quilômetros da fron- 
teira com Mato Grosso do Sul. Alguns meses mais tarde voltaram a acampar, dessa vez na Fazenda Capim distante poucos quilômetros da cidade onde haviam se instalado. Finalmente quando surgiu uma vaga num assentamento novo da região, no final de 2005, foram assentados. Por outro lado, Edesmaria, Sino e Márcia não seguiram o mesmo percurso que a família Reis. Depois de ter saído do acampamento Dom Hélder, passaram também pelo acampamento da CUT e finalmente se separaram da família Reis e continuaram a peregrinação por vários outros acampamentos, na região noroeste do estado. Como mencionei anteriormente, Edesmaria já havia participado, na Bahia, de vários outros acampamentos, especificamente na região de Feira de Santana; portanto, havia chegado a São Paulo com um capital de conhecimentos sobre a arte da ocupação de terras. Assim, Edesmaria, estando num acampamento do MST a convite de um sindicalista da região, mudou para um acampamento da CUT e de lá saiu com 12 famílias para outro acampamento no município de Andradina, onde ela liderava o grupo de acampados. ${ }^{8} \mathrm{O}$ acampamento liderado por ela não durou muito tempo; em menos de três meses, ela, com seu filho, sua nora e várias outras famílias, acabaram-se instalando num acampamento do MST montado numa fazenda a 40 quilômetros da fronteira com o estado de Mato Grosso do Sul. No final de 2005, Sino, o filho de Edesmaria, e sua nora decidiram sair do acampamento. Em março de 2006, Edes decidiu sair também e retornou para sua terra natal na Bahia. Meses depois ela decidiu voltar novamente para o acampamento onde ficou até meados de 2008. Edes depois se instalou em um "acampamento de José Rainha", 9 na região de Araçatuba. Finalmente, em agosto de 2009 ela foi assentada, ou, como ela me disse, "entrou na terra" ${ }^{10}$

8 Para uma análise etnográfica dessas mudanças e inserção de Edes no mundo das ocupações de terra ver Loera, 2010.

9 Militante do MST que "rachou" com outras lideranças fortes desse movimento em São Paulo e começou a organizar acampamentos por iniciativa própria.

10 Conhecia Edesmaria como Maria, é assim que as pessoas se referiam a ela quando estava no Terra Sem Males. Quando voltou da Bahia, ela mesma começou a se apresentar como Edes; quando estive com ela naquele estado, 


\section{Caracterização dos lugares de pesquisa}

Seguir o percurso anteriormente descrito me permitiu realizar trabalho de campo em diversos acampamentos do estado de São Paulo e ter uma perspectiva, em diferentes tempos e espaços, do mundo das ocupações de terra.

Antes de descrever brevemente as características dos acampamentos que fazem parte desse percurso, parece-me importante esclarecer que existe uma diferença entre ocupação e acampamento. O primeiro termo se refere ao momento da entrada na propriedade e os primeiros dias nos quais novos acampados e principalmente os velhos de acampamento e assentados ficam na propriedade ocupada, apoiando o movimento e mostrando para os novatos a tecnologia de montagem do acampamento. Acampamento é o termo usado uma vez que as barracas são montadas, a bandeira do movimento é colocada e famílias novas começam a se instalar debaixo da lona. Não necessariamente as famílias acampadas participam da ocupação que cria o acampamento, algumas, a convite de outras famílias assentadas ou acampadas, se instalam dias, meses ou inclusive anos depois num acampamento já constituído. Também não necessariamente um acampamento se constitui a partir de uma ocupação, no interior de São Paulo, muitas vezes os acampamentos são simplesmente montados e novas famílias e barracos vão se agregando.

Segundo Navarro (2002), os acampamentos estariam constituídos pelo lumpesinato, uma categoria na qual ele aglomera os pobres do meio rural. No entanto, como identificado por Macedo (2003), Ondetti (2006), Wolford (2006) e Loera (2006), os acampamentos são constituídos por pessoas de origens diversas e por uma heterogeneidade de perfis socioeconômicos, o que põe em questão argumentos como o de Navarro, isto é, "a crença de que os acampa-

dei-me conta de que é por esse nome que seus parentes e amigos da Bahia a conhecem. Nesta ocasião não analisarei esse aspecto, mas estou ciente de que o nome, como menciona Pina Cabral (2007), está intimamente ligado à constituição social das pessoas. Os nomes, para esse autor, funcionam como marcas de relações afetivas. 
mentos sejam constituídos por pessoas com perfis socioeconômicos homogêneos, a ponto de poderem ser enquadradas em categorias determinadas" (Macedo, 2003, p.5).

Os acampamentos são instalados em diferentes espaços e podem ser organizados por diferentes movimentos; no entanto, há certos elementos que se repetem: são montados em lugares estratégicos, para que sejam visíveis de longe; são instalados o que os acampados chamam de barracos ou barracas de lona, uma estrutura feita com paus de bambu ou madeira e coberta com plástico preto ou colorido, que é chamado de lona.

Alguns acampados, principalmente os novatos, ao se instalarem debaixo da lona, levam consigo muitos pertences, inclusive móveis, como fogão, armários, camas etc., e acabam montando praticamente uma casa dentro do barraco. Já os velhos acampados, com experiência na arte de acampar, geralmente carregam o mínimo de coisas possível, pois sabem que é melhor assim, em caso de um despejo, ou de ter que mudar de acampamento ou sair para realizar uma nova ocupação.

$\mathrm{Na}$ maioria das ocupações e quando o acampamento começa a ser montado, as barracas são divididas em blocos ou grupos de famílias, segundo parentesco, afinidade ou conforme ordem de chegada. Uma vez que o acampamento está montado, dirigentes do acampamento dividem uma série de tarefas, que devem ser compartilhadas pelos acampados; na maioria dos acampamentos organizados pelo MST, essas tarefas se realizam por meio de núcleos, setores, grupos, comissões, brigadas, equipes etc.

A maioria dos acampamentos recebe doações em roupa, alimento, lona, que são divididas entre as famílias, e, muitas vezes, recebe uma cesta básica, ${ }^{11}$ mas, na realidade, o que realmente sustenta os acampamentos são, por um lado, os chamados bicos, ou seja, traba-

11 Em conversa pessoal com um funcionário do Instituto de Terras do Estado de São Paulo, ele mencionou que dentre as categorias que têm prioridade no recebimento da cesta básica estão: acampados, moradores de rua, quilombolas e indígenas. 
lhos eventuais que os acampados realizam nas cidades ou fazendas próximas; o recebimento da aposentadoria ${ }^{12}$ e outros benefícios de programas do governo, como o bolsa-família; ${ }^{13}$ assim como a ajuda de parentes ou dos acampados conhecidos como andorinhas. Em pesquisa recente realizada em acampamentos do oeste do estado de São Paulo, percebi que os andorinhas são fundamentais para a continuidade e manutenção dos acampamentos, porque eles mantêm com os moradores relações de interdependência e, nesse processo, reatualizam a lógica dos compromissos e obrigações, não só pela troca de favores e serviços e outros bens materiais e imateriais, como informações, notícias e afetos, fazendo com que a vida debaixo da lona preta se torne possível (Loera, 2013). ${ }^{14}$

Por outro lado, na maioria dos acampamentos organizados pelo MST, é obrigatório o cumprimento da chamada disciplina, o que significa, entre outras coisas, cumprir certas tarefas coletivas, seja no setor de educação, segurança, agricultura, saúde, seja no de comunicação. Como assinalado por Ondetti (2006), em acampamentos organizados por outros movimentos que não o MST, a disciplina não é tão cobrada; no entanto, como revelou a pesquisa de campo, há casos nos quais nos próprios acampamentos organizados por militantes do MST a disciplina é inexistente. A divisão de tarefas, segundo Stédile e Fernandes, é o segundo princípio organizativo do MST, pois "permite à organização crescer e trazer para dentro dela aptidões pessoais” (1999, p.41). No entanto, como menciona

12 Corresponde aproximadamente a 70\% do salário, dependendo do tipo de aposentadoria (por idade, por invalidez, por tipo de contribuição, especial). $\mathrm{O}$ benefício pago não pode ser menor do que um salário mínimo por mês.

13 O Programa Bolsa-Família (PBF) faz parte do programa federal Fome Zero, implementado pelo governo de Luiz Inácio Lula da Silva em 2004. É um programa de transferência direta de renda com condicionalidades, que beneficia famílias em situação de pobreza e extrema pobreza. Os valores pagos pelo Programa Bolsa-Família variam de acordo com a renda mensal por pessoa da família e o número de crianças e adolescentes até 17 anos.

14 Esta pesquisa "Formas de acampamento" (2010-2015) compõe parte do auxílio Jovem Pesquisador financiado pela Fundação de Amparo à Pesquisa do Estado de São Paulo (processo 2010/02331-6). 
Loera, nos acampamentos "esse princípio organizativo funciona melhor entre os jovens, mas, entre outros acampados, funciona porque faz parte das obrigações de acampados, faz parte da disciplina" (2006, p.107). Ainda segundo a autora, "são principalmente os adultos homens que participam de setores como segurança, saúde e almoxarifado. Os jovens e mulheres adultas do acampamento parecem gostar mais do setor de educação, realizando desde o planejamento até a implementação das atividades com as crianças de diferentes idades" (Loera, 2006, p.107).

Em alguns acampamentos do MST os acampados têm também a obrigação de participar das mobilizações organizadas pelo movimento. Como especificado no regimento interno de dois acampamentos: "É um dever de todos os acampados, contribuir e participar das atividades coletivas e do bem comum: lutas, marchas e ocupações, reuniões dos grupos e setores, participar das assembleias e dos trabalhos do acampamento". ${ }^{15}$

Apesar de os acampamentos seguirem um modelo de organização, existem particularidades que dependem do movimento que organiza o acampamento, das trajetórias sociais dos militantes e dirigentes envolvidos com a organização deles, da origem e das características socioeconômicas das famílias que se instalam debaixo da lona e das características da região onde os acampamentos são montados.

\section{O acampamento Terra Sem Males (TSM) ${ }^{16}$}

O TSM ganhou vida em abril de 2002, no município de Bragança Paulista, com a ocupação da Fazenda Capuava, que reuniu mais de 400 famílias entre novos e velhos acampados e assentados. A ocu-

15 Regimento Interno dos Acampamentos Terra Sem Males e Irmã Alberta, 2003.

16 O trabalho de campo nesse acampamento foi realizado em diversas datas. Em abril de 2002, de abril a julho de 2003, em setembro de 2003 e em fevereiro de 2004. 
pação foi uma de tantas organizadas em todo o território nacional pelo Movimento dos Trabalhadores Rurais Sem-Terra (MST), para lembrar a morte de 19 trabalhadores rurais ocorrida em 1996 no Eldorado dos Carajás no estado do Pará. ${ }^{17}$

A maioria das famílias acampadas era originária da região de Campinas, no interior de São Paulo, e dos municípios próximos, e tinham sido convidadas para participar da ocupação por conhecidos ou parentes que já eram assentados ou faziam parte de outros acampamentos. Alguns deles também estavam participando da ocupação.

O acampamento TSM ficou aproximadamente cinco meses nas terras da Fazenda Capuava. Em Junho de 2002, um juiz de Bragança Paulista decretou que as famílias acampadas poderiam ficar só 60 dias naquelas terras. Quando o prazo se cumpriu, as famílias foram despejadas e o acampamento foi instalado no município de Franco da Rocha, na região metropolitana (RM) de São Paulo, e menos de um mês depois as famílias mudaram novamente e o acampamento foi montado no município de Cajamar, ainda na região metropolitana (RM-SP). ${ }^{18}$ As famílias do TSM ocuparam, com outras famílias que depois conformariam o acampamento Irmã Alberta, uma propriedade na periferia da pequena cidade de Polvilho. Em julho de 2003, um contingente de 50 famílias de ambos os acampamentos saiu de Cajamar para ir se instalar em outro acampamento, o Dom Hélder Câmara, no município de Birigui, ao noroeste do estado de São Paulo.

Em outubro de 2003, as famílias do TSM que ficaram acampadas em Cajamar saíram de lá para se instalar temporariamente em

17 Para mais detalhes sobre a relação entre o massacre de Eldorado dos Carajás, o Estado e a intensificação das ocupações de terra organizadas pelo MST a partir de 1995, ver Ondetti (2006).

18 Utilizou-se a terminologia "oficial”, que divide o estado de São Paulo em municípios dentro de regiões administrativas (RA), algumas destas inseridas em regiões metropolitanas $(\mathrm{RM})$. Na terminologia nativa também se faz referência a regiões que, como mencionei anteriormente, se referem aos escritórios nos quais a militância do MST está dividida, constituindo as chamadas Regionais. 
terras do assentamento Sumaré II, a 100 quilômetros da capital do estado. Naquela ocasião contaram com o apoio dos próprios assentados, que cederam uma área de 2 hectares de terra para a instalação do acampamento. Em fevereiro de 2004, as famílias do acampamento saíram do Sumaré e ocuparam uma fazenda em Americana. As famílias do TSM mudaram novamente e montaram o acampamento no município de Itu e depois foram para a região de Ribeirão Preto, a 300 quilômetros ao norte da capital do estado de São Paulo.

É importante mencionar que nesse percurso muitas famílias, como no caso da dos Reis e Cerqueira, decidiram sair do TSM e ir para outros acampamentos, outras simplesmente desistiram de ficar acampando ou foram expulsas e outras continuaram nesse acampamento, com famílias novas que foram se instalando debaixo da lona. ${ }^{19}$

\section{O acampamento Dom Hélder Câmara ${ }^{20}$}

Cinquenta famílias de acampados do TSM saíram de Cajamar no começo de junho de 2003, com a expectativa de serem assentadas na região de Araçatuba, e ocuparam a Fazenda Santa Rosa perto da cidade de Araçatuba, e dois dias depois foram despejadas. Depois ocuparam a Fazenda Araçá, também em Araçatuba, onde ficaram uma semana e também foram despejados. Finalmente ocuparam a beira da pista ao lado da Fazenda Pau d'Alho, no município de Birigui, a mais de 500 quilômetros ao noroeste da cidade de São Paulo. Foi ali que o acampamento Dom Hélder Câmara foi constituído. As barracas foram montadas perto de uma pequena reserva de mata, na beira da fazenda. O nome do acampamento foi decidido em assembleia e sugerido pelos militantes do MST que

19 As expulsões de acampados se dão, na maioria das vezes, quando o comportamento do acampado dentro do acampamento é considerado inadequado.

20 O trabalho de campo nesse acampamento foi realizado em julho de $2003 \mathrm{e} \mathrm{em}$ novembro desse mesmo ano. 
acompanhavam as famílias de acampados e coordenavam a organização do novo acampamento. Durante vários meses o acampamento esteve ocupado só pelas famílias vindas do TSM e da região de Campinas e São Paulo. E foram essas mesmas famílias que, em conjunto com militantes da região, realizaram trabalho de base em cidades e bairros rurais próximos ao acampamento, convidando novas famílias para irem instalar-se no Dom Hélder. ${ }^{21} \mathrm{O}$ acampamento ficou nesse local mais de um ano e meio, de junho de 2003 até começo de 2005. Durante esse tempo, várias famílias desistiram e saíram do acampamento, as que ficaram realizaram outras mobilizações, e, finalmente, em abril de 2005, o acampamento Dom Hélder foi desmanchado e as famílias ocuparam a Fazenda Macali a 40 quilômetros da fronteira com Mato Grosso do Sul, montando um acampamento com famílias de moradores da fazenda que já estavam no local e famílias vindas de cidades próximas. No final de 2005, a fazenda foi finalmente liberada para reforma agrária e as famílias foram assentadas.

\section{Acampamento Família Unidas ${ }^{22}$}

Devo lembrar que a família extensa Reis-Cerqueira foi uma das famílias que saíram do acampamento Dom Hélder Câmara. A convite de um sindicalista da região, foram acampar num acam-

21 Trabalho de base é o termo nativo que designa o convite que é feito em bairros, periferias das cidades e bairros rurais, para que as pessoas, moradores nesses lugares, participem de uma ocupação de terra ou instalem uma barraca de lona num acampamento já existente.

22 O trabalho de campo nesse acampamento foi realizado em julho de 2006, em agosto de 2007 e em janeiro de 2009. Em julho de 2007 e janeiro de 2009, também foi realizado trabalho de campo em cidades próximas ao acampamento, com autoridades locais e com famílias que estavam acampadas, mas passavam os finais de semana nas suas casas na cidade, assim como também com outras famílias que já haviam estado acampadas, mas haviam desistido do acampamento. Também foram realizadas entrevistas com militantes do MST pertencentes às Regionais do MST. 
pamento organizado pela CUT, especificamente por dirigentes vinculados ao Sindicato dos Trabalhadores da Agricultura Familiar de Andradina (Sintraf) que estava montado na Fazenda Cafeeira na região no interior do estado conhecida como Pontal. Foi ali que a família se dividiu, Cleusa, Alfredo, os filhos e a nora decidiram sair do acampamento e foram morar na cidade de Castilho próxima a Andradina. ${ }^{23}$ Já Edesmaria, seu filho e a nora continuaram acampados na Cafeeira, de lá Edesmaria com outras 12 famílias saíram e montaram um pequeno acampamento na Fazenda Santa Cruz, num local conhecido como Três Pontes, no município de Andradina; lá ficaram menos de três meses e depois se instalaram no acampamento Famílias Unidas, localizado na mesma região.

O acampamento Famílias Unidas foi montado após uma grande ocupação em dezembro de 2003. ${ }^{24}$ A maioria das famílias que participou da ocupação era originária de outros acampamentos próximos. A ocupação e a montagem desse acampamento, tal como o da Cafeeira, foram originalmente organizadas por membros do sindicato (Sintraf). Um grupo de famílias novas que estavam acampadas sentiu que a atuação do sindicato na organização e gerenciamento do acampamento deixava muito a desejar e decidiram procurar representantes do MST da região, ou, como o coordenador do acampamento disse, decidiram caçar um movimento. Militantes do MST decidiram apoiar as famílias e foi organizada uma nova ocupação na mesma Fazenda, onde participaram famílias novas convidadas em trabalho de base feito por militantes do MST e por famílias

23 Devo ressaltar que a família Reis ficou quase um ano fora dos acampamentos; depois, a convite de um militante do MST, essa família voltaria novamente a acampar, dessa vez em terras da Fazenda Capim, no município de Castilho. De lá, foram indicados para ser assentados na Fazenda Macali juntamente com famílias do acampamento Dom Hélder Câmara e que conheciam desde o TSM.

24 Este acampamento diferentemente do Terra Sem Males e do Dom Hélder ficou montado no mesmo lugar, próximo à cidade de Andradina por quase 6 anos. Para detalhes sobre o percurso desses dois primeiros acampamentos, ver o Mapa 2 em "Anexos". 
de acampados que preferiam ter o MST ao Sintraf organizando o acampamento.

No começo de 2006, o acampamento foi dividido em dois movimentos, MST e MTR. Uma das razões da divisão foi uma briga entre acampados, que não concordavam com o fato de a militância do MST permitir os moradores de final de semana no acampamento. Em outubro de 2008, o acampamento se dividiu mais uma vez, e assim um grupo de acampados decidiu ficar sob a bandeira do Sintraf e escolheu um velho acampado como coordenador. Uma das principais razões da briga foi que alguns acampados que ainda continuavam sob a bandeira do MST não concordavam com a exigência desse movimento de participar das chamadas jornadas ou mobilizações (isto é, marchas, passeatas, ocupações de terras, ocupações de prédios públicos, bloqueios de estrada).

Em 2009 o acampamento tinha pouco mais de 170 famílias divididas em três movimentos: MST, MTR e Sintraf com diferentes regras, organização e formas de atuação dos movimentos.

\section{Assentamento Macali}

Esse assentamento foi criado em novembro de 2005 numa área de quase 3 mil hectares de terra localizada ao noroeste do estado de São Paulo. Desde 2004 um grupo de 120 famílias de antigos moradores da fazenda e famílias de novos acampados mantinha, sob a bandeira do MST, um acampamento nessas terras. Um grupo de 14 famílias do acampamento Dom Hélder Câmara saiu de Birigui no começo de 2005 e se juntou a esse contingente de acampados da Macali. No decorrer de menos de um ano, outras famílias de acampados, vindas de diversos acampamentos da região e de outros instalados em municípios não tão próximos, foram indicadas por militantes do MST para se juntarem ao acampamento da Macali. Quando a propriedade foi liberada para assentamento, foram repartidos mais de 160 lotes de pouco mais de 5 hectares cada um. Quando as famílias entraram nas terras, a propriedade estava plan- 
tada com cana. Lideranças que representavam os antigos acampados do Dom Hélder começaram uma mobilização entre assentados, Incra e empresas privadas, para recuperar o dinheiro da cana, isto é, o dinheiro que seria pago pela venda da cana removida de cada lote. Foi nesse contexto que começou uma série de disputas entre os diferentes grupos de assentados pela legitimidade do seu tempo de acampamento.

A família Reis foi uma das famílias escolhidas pelo MST para ter uma vaga no assentamento. A indicação de famílias, por parte do movimento, foi também um marco de disputa no qual o tempo de acampamento figurou como elemento central. 


\section{1 \\ TEMPO DE BARRACO}

No mundo das ocupações de terra, aqueles que participam de uma ocupação e subsequentemente de um acampamento devem seguir uma etiqueta particular: montar um barraco e se instalar debaixo da lona preta. Essa é a forma apropriada de proceder e de "dizer" que se quer terra e que se "pertence" a determinado acampamento. Essa linguagem é entendida e compartilhada pelos trabalhadores, ${ }^{1}$ pelas lideranças e militantes dos movimentos e pelos representantes do Estado encarregados das desapropriações de terras. O barraco de lona se torna, então, uma espécie de inscrição, sinaliza a partici-

1 A pesquisa em campo mostrou que o termo "trabalhador rural" é usado, principalmente, pelas lideranças dos movimentos que organizam as ocupações e acampamentos para designar de maneira geral a população que se instala debaixo da lona; é usado também pelos representantes do Incra, na mídia e no senso comum; por exemplo, ao afirmar que todos os acampados seriam "trabalhadores rurais", ou teriam uma origem rural ou camponesa, no entanto, em acampamentos do estado de São Paulo encontramos uma população diversa, também de origem urbana, que não se considera como "trabalhador rural" e se autodesigna como acampado ou simplesmente como trabalhador. Portanto, atrevo-me a sugerir que "trabalhador rural" se tornou, hoje em dia, uma categoria política, no sentido em que é acionado principalmente pelos movimentos para explicitar o vínculo dos acampados com a demanda por terra. 
pação em um acampamento e é uma forma de marcar a entrada no mundo das ocupações de terra. Conforme Sigaud:

Ao montar sua barraca o trabalhador diz que quer a terra. Esta afirmação está dirigida ao Incra, que no momento de selecionar os futuros beneficiários irá contabilizar os que se encontram debaixo da lona preta; ao movimento que o incluirá em suas listas a serem apresentadas ao Incra; e aos demais que se encontram no acampamento que irão reconhecê-lo como alguém que quer a terra. A barraca legitima a pretensão a pegar terra; é a prova do interesse em ser contemplado pela redistribuição das terras. (2004, p.19-20)

Em alguns acampamentos é possível montar uma barraca e não morar nela, em outros, a barraca não é suficiente para ser considerada como parte do acampamento, para isso é necessário, de fato, morar no acampamento. ${ }^{2}$ No entanto, em ambos os casos os trabalhadores compartilham uma crença, nas palavras de Sigaud (2005), a de que um futuro melhor passa pela lona preta. Ainda, segundo essa autora, a lona preta começa a fazer parte de um repertório dos possíveis para melhorar de vida, figurando como mais uma alternativa dentro de um horizonte de possibilidades.

Desse modo, no mundo das ocupações de terra, o tempo de lona ou tempo de barraco ao qual se faz referência também como tempo de acampamento se torna um requisito incontornável para quem pretende ser beneficiário da reforma agrária, e a barraca de lona se torna uma prova, uma amostra desse "tempo". Em outras palavras, o tempo de acampamento pode tornar-se visível através do barraco.

No mundo das ocupações de terra, a barraca de lona é um bem precioso, é objeto de negociações, trocas e disputas, tornando-se

2 Nos acampamentos encontramos uma diversidade de situações: há quem não acampa, mas tem um representante, isto é, um parente ou amigo que fica acampado no lugar, há quem fica debaixo da lona só alguns dias durante a semana e há quem mora no acampamento e monta "literalmente" sua casa dentro do barraco. Essas especificidades serão abordadas ao longo do texto. 
um elemento central na compreensão da dinâmica e constituição social dos acampamentos.

Borges (2003), na sua etnografia sobre o Recanto das Emas, uma cidade satélite de Brasília, descreve situações vivenciadas por moradoras do lugar, situações que evidenciam relações de status que giram em torno do "barraco" (categoria nativa usada para descrever um tipo de moradia daquele lugar). A autora identificou entre os moradores do Recanto certos atributos e hierarquias associados ao barraco. Atributos que passam pelo modo de vida das pessoas que nele vivem, e hierarquias que passam pelo tipo e localização dos barracos e lotes no espaço do lugar. O barraco, para essa autora, revelou-se como um lugar-evento privilegiado para compreender significados e valores do modo de vida dos moradores do lugar. Do mesmo modo, no mundo das ocupações de terra, o barraco é uma porta de entrada para identificar aqueles participantes desse mundo social associados às categorias nativas: velhos, novatos $\mathrm{e}$ novos acampados, moradores e apoios ou andorinhas; assim como as diferentes percepções do tempo de barraco, por parte dos indivíduos associados a essas categorias.

\section{Novos, novatos e velhos acampados}

Geralmente quando uma pessoa chega em um acampamento para se instalar debaixo da lona, o coordenador designa um lugar para ela dentro do acampamento; logo, espera-se que o acampado tenha respeitado o procedimento de entrada, ou seja, falar com o coordenador e pedir uma vaga. ${ }^{3}$ Para o caso dos acampamentos da Mata Sul Pernambucana, Sigaud menciona que o uso do termo vaga "não é neutro: indica que a entrada no acampamento é representada a partir do modelo da 'entrada' em um emprego" (2000, p.89).

3 Como será tratado adiante, em alguns acampamentos, antes de montar um barraco é necessário primeiro negociar uma vaga. 
Muitas vezes a "entrada" de um novo acampado no acampamento é precedida de uma investigação por parte do coordenador. Quem é? De onde vem? E como ficou sabendo do acampamento? Essa investigação como critério de acesso é parecido também com o critério de entrada nos acampamentos da Mata Pernambucana, como identificado por L'Estoîle e Pinheiro (2006). Para esses autores, o "conhecimento" prévio da pessoa era um critério nos acampamentos organizados pelos sindicatos rurais para aceitar a "entrada" de novas pessoas. No caso da acampada Edesmaria, por exemplo, o fato da irmã dela ser assentada e conhecer parentes do coordenador do acampamento facilitou sua "entrada" no Terra Sem Males.

No TSM, depois que o coordenador dava a vaga, os novos eram instalados nos últimos grupos de barracas formados, e na barraca recém-montada era colocado o número do grupo e do barraco. ${ }^{4}$ Para os coordenadores, essa era uma forma de ter um controle das "entradas" e "saídas" de acampados; e, pela própria numeração das barracas, os acampados já podiam saber quem era novo no acampamento. Uma vez instalados, os novos podiam optar por mudar de grupo, trocando de lugar com outra pessoa e se instalando numa barraca já montada ou desmontar seu barraco e montá-lo em outro lugar. Mas, na chegada, devia ser respeitada a ordem dos barracos e o lugar designado.

O procedimento de entrada pode variar um pouco de um acampamento para outro, mas o pedido de vaga e a instalação da barraca como ato de inscrição é um denominador comum. Zélia, acampada no acampamento Famílias Unidas, relatava o processo de entrada num acampamento montado em Aracanguá, no município de Araçatuba (SP). Ela, antes de acampar no acampamento Famílias Unidas, morava em uma pequena vila a 11 quilômetros desse acampamento. Zélia e seu marido Cido, no começo de 2008, foram

4 Como tratado por Loera (2006), o acampamento Terra Sem Males, quando estava montado no município de Cajamar, estava dividido em 11 grupos de barracas. Cada grupo estava composto por cinco ou seis famílias, que, muitas vezes, estavam vinculadas entre si por laços de parentesco. 
convidados por outra acampada para visitar um acampamento em Aracanguá. Segundo Zélia, "Cido adora pescar e ficou doido quando soube que o acampamento era na beira do rio". Eles foram de carro até o acampamento e, conhecendo o procedimento, chegando ao local foram conversar com a coordenadora; ela os levou para conhecer o acampamento, mostrando a forma de funcionamento e indicando "onde poderiam instalar o barraco". Ainda segundo Zélia, no acampamento estava "tudo muito apertado", e "os barracos dos novos ficavam num canto mais apertadinho ainda", o acampamento estava longe da cidade e não tinha transporte para as crianças irem à escola, isso, entre outras coisas, fez Zélia desistir da sua decisão de mudar de acampamento.

As pessoas que pretendem instalar-se debaixo da lona geralmente não escolhem participar de um movimento, e sim de um acampamento. Essa decisão não só depende dos laços de amizade ou parentesco que se tem com pessoas que já estão acampadas, mas também depende do contexto e das situações vividas anteriormente e das expectativas para o futuro que cada acampado tem. A proximidade com as cidades, nos acampamentos do estado de São Paulo, é hoje em dia um dos critérios de escolha para os que vão mudar de acampamento ou aqueles que irão instalar-se pela primeira vez debaixo da lona.

A pesquisa de campo também revelou que militantes e dirigentes dos movimentos preferem atuar em acampamentos próximos às cidades, já que facilita a mobilização de recursos e apoios para os acampamentos, assim como facilita os deslocamentos no caso de uma mobilização.

As cidades têm uma importância fundamental na dinâmica socioeconômica dos próprios acampamentos, já que não é só onde muitos dos acampados trabalham, compram alimento, fazem uso dos serviços de saúde, ou fazem algum trâmite, mas também, muitas vezes, são lugares onde trocas e negociações acontecem: entre acampados, acampados e militantes ou lideranças dos movimentos e autoridades locais. A cidade, e seus serviços, é também um lugar de distração ou espaço de lazer para os acampados, principalmente 
para os jovens que moram nos acampamentos, que, durante os finais de semana, se deslocam para fazer compras e reunir-se com outros jovens. De fato, existe uma crença que circula entre os acampados, de que um acampamento perdura mais e os acampados acabam desistindo menos quando o acampamento fica perto de uma cidade ou vila, por menor que esta seja.

No TSM, um novo acampado podia ser identificado não só pela numeração e localização do seu barraco no espaço do acampamento, mas também a inexperiência no mundo das ocupações podia ser identificada e medida pelos velhos acampados pelo número de pertences que se levava ao acampamento e se encontravam no barraco. Para os acampados que detêm o estatuto de velhos acampados ou velhos de acampamento, aquele que chega com mudança é identificado, na maioria das vezes, como novato.

Edesmaria, velha de acampamento, me explicava que geralmente os novos "não sabem como funciona" [o mundo das ocupações de terra]; segundo ela, "ganhar terra é algo demorado", e, no caso de um despejo ou de ter que mudar de acampamento ou sair para realizar uma nova ocupação, era melhor carregar o mínimo de coisas possível, e, caso a saída fosse temporária (por participar de uma ocupação e abrir um acampamento), ${ }^{5}$ era melhor não ter muita coisa dentro do barraco, pois não era raro pessoas do mesmo acampamento aproveitarem a saída de alguns para se apropriarem das coisas alheias. ${ }^{6}$

5 Abrir acampamento é uma expressão usada entre participantes dos acampamentos e significa realizar uma ocupação que irá fundar um acampamento, diferentemente de uma ocupação que é realizada sabendo, a priori, que irão ocupar, mas logo deverão desmanchar os barracos e sair do local. Em contextos rurais, "abrir um lugar", uma roça, por exemplo, significa abrir um espaço de vida. Essa observação vai ganhar sentido adiante no item "Barracos e barracos", também voltarei a tratar sobre essa expressão de maneira mais detalhada no capítulo "Tempo de luta".

6 Como mostrado em Loera (2006), no TSM existia um regulamento interno que fazia parte da disciplina socializada pela militância do MST. Segundo o regulamento, "era proibido se apropriar de qualquer objeto alheio"; no 
Cleusa, que já havia cumprido mais de um ano de acampamento, lembrava sua chegada como novata na Capuava, a fazenda onde foi realizada a ocupação que deu vida ao Terra Sem Males:

Foi pelo dia 3 de abril [de 2002] que o Alfredo [seu marido] participou das reunião do movimento, só que dali foi logo no começo da ocupação. Ele ficou uma semana, foi de sábado para domingo a ocupação e nós ia desistir, ele não queria vim no começo, não queria de jeito nenhum; ali veio uma turma do assentamento [Sumaré II], aí voltaram... Nossa, mais é bonito lá! Porque as terras vão ser lá mesmo! É porque no começo falava que ia ficar lá mesmo, né, aí ele ficou doido, "agora eu vou, agora eu vou"; aí, quando passou uma semana que foi... a data eu não lembro, aí, vinha uma caminhonete de lá, era dona Cida mesmo [assentada de Sumaré], que mandou avisar que quem tivesse ido na ocupação que uma caminhonete vinha para trazer as coisas: colchão, essas coisas. Daí, nós viemos, ele ficou duas semanas, ali ele já voltou... "Porque vou vender a casa, porque vou embora, porque as terras vai sair lá"; e eu: "Não, você não vai vender essa casa" [...]. Aí, vinha todo mundo, todos os novos [acampados] de lá [de Sumaré] com seu carrinho, aí nós viemos, veio eu e o Júnior, fez um ano já. [...] aí, [quando chegamos] em Atibaia, eram uma 5 horas, 6 da manhã na Capuava, mas chegamos lá, tudo escuro; ali olhava assim pro alto e falava para seu Carlitos: "Meu Deus do céu! Esse que é o lugar? Ah! não sei se vou ficar aqui, não". Aí, seu Carlito, que já era velho de acampamento, falava assim: "Você vai ver, você vai gostar". Aí ficou; aí no outro dia cedo, eu achei bonito mesmo. Aí peguei e falei assim: "O quê! Eu não volto mais para Sumaré de jeito nenhum”. Aí eu falei assim: "Ah, o Alfredo que se vire lá, que venda a casa, porque lá eu não vou voltar mais, não"; aí fiquei duas semanas, aí seu Adelmar, que estava indo para esses lados, lá, aí eu mandei o recado, falei: "Fala pro Alfredo vender a casa lá, dar um jeito que não vou mais, não"; aí ele foi e eu mandei trazer umas coisas para mim, eu já tinha

entanto, as regras muitas vezes eram quebradas e, dentro de certo limite, um desrespeito à disciplina era tolerado. 
deixado separado roupa, tudo, umas bolsas, aí passou aqueles dias e não voltei mais, aí o Alfredo vendeu a casa lá pra esse homem e a turma falando que ia ficar ali, que ia ficar ali [na Capuava]. Alfredo vendeu tudo lá [em Sumaré] e veio com aquela mudança! (Cleusa, TSM, Cajamar, maio de 2003)

A chegada de Noé como novato no acampamento Dom Hélder Câmara, em junho de 2003, foi muito parecida com o relatado por Cleusa. Ele foi participar primeiro da ocupação e depois, quando o acampamento estava montado, chegou sua esposa com seus dois filhos. Eles venderam a casa que tinham em Viracopos, na região de Campinas, e percorreram mais de 600 quilômetros até Birigui; como ele me disse: "Fizemos toda uma mudança, deixando a casa e a vida ruim pra trás". Betinho também chegou como novato para se instalar no Dom Hélder Câmara. Ele e sua esposa Cida moravam em Araçatuba e haviam visto na TV local uma matéria sobre os acampamentos instalados na região, pouco tempo depois ouviram que no bairro estavam fazendo "trabalho de base para ir para a terra”. Eles chegaram no Dom Hélder no final de 2003, levando consigo também a mudança.

A maioria dos novatos ao se dirigirem às terras ocupadas o fazem deixando toda uma vida para trás e com a expectativa de que rapidamente irão se fixar num lugar e terão a possibilidade num futuro próximo de reconstruir suas vidas ao ganharem um lote de terra, quando isso não acontece no tempo e da maneira como esperavam mencionam sentir-se enganados ou traídos por aqueles que os convidaram para acampar.

Devo mencionar que, nos acampamentos nos quais foi realizada a maior parte do trabalho de campo, nem todos os que levavam mudança e montavam sua casa no barraco eram novatos, nem todos aqueles que só tinham montado seu barraco e levavam poucos pertences eram velhos acampados. Muitas vezes, novos acampados que se instalam num acampamento próximo a seus lugares de origem se deslocam com poucos pertences, muitos deles inclusive mantêm uma casa na cidade. Esse foi o caso, por exemplo, de Zefa e Zé, um 
casal que acampou pela primeira vez em 2004, no Dom Hélder Câmara. Hoje em dia são assentados e, durante todo o tempo em que estiveram acampados (quase quatro anos), mantiveram sua casa fechada na cidade de Andradina, e só quando as terras saíram começaram a levar todos os móveis e pertences da casa de Andradina para o assentamento.

Contudo, no TSM e no Dom Hélder Câmara, a maioria dos novatos, principalmente famílias que foram se instalando no acampamento quando já estava montado, se encontravam na mesma situação de Noé, Cleusa e Alfredo e Betinho e Cida; haviam chegado com a mudança, alguns, inclusive, como assinalado em Loera (2006), montaram sua casa no barraco. Segundo a autora:

É comum encontrar essas diferenças dentro das barracas dos sem-terra: alguns deles, quando vão fazer ocupação, só carregam alguns pertences e montam a barraca com pouca coisa; geralmente são os que já passaram por outros acampamentos; outros, geralmente "novos" acampados, voltam para suas cidades e vão trazendo aos poucos todos os seus pertences e praticamente montam uma "casa" dentro da barraca, com fogão a gás, camas, armários, móveis, etc. (Loera, 2006, p.76)

Cleusa aprendera, com mais de um ano de acampamento, que "sem-terras levam vida de ciganos, não dá para se apegar a nada".

Edinéia do TSM, que acampava com sua mãe, também relacionou seu tempo de acampamento com a itinerância. Ela lembrou que, depois de um ano de acampamento, haviam perdido várias coisas, entre panelas, louça e objetos pessoais, e depois de tanta mudança haviam aprendido a ficar com um mínimo de coisas dentro do barraco, inclusive, ela mencionou que "sequer tinham fogão a gás", haviam aprendido que "nessa vida de acampado" era melhor ter fogão a lenha. Ela não se considerava como novata, mas tampouco como velha acampada. Segundo ela, o seu "tempo de barraco" ainda era pouco, tomando como referência outros acampados do TSM, que tinham três, quatro ou mais anos de acampamento. 
Esse era o caso de acampadas como Geni e Gracilda, que, se fizéssemos uma contagem cronológica do tempo de barraco de ambas, poderíamos contar mais de 15 anos de acampamento.

Geni, velha acampada acostumada com as contínuas mudanças de acampamento, quase não tinha móveis no seu barraco, guardava sua roupa em sacolas de plástico e tinha um mínimo de pertences. Inclusive em 2005, quando a encontrei novamente no TSM, que na época estava montado próximo à cidade de Itu (SP), sua filha e seu genro haviam decidido também ir acampar. Para eles, Geni e seu marido haviam montado uma pequena barraquinha de lona em forma de barraca de camping ao lado do seu barraco, na qual só tinha um colchão. Como velhos de acampamento, sabiam que o importante era montar um barraco que pudesse ser montado e desmontado com facilidade e com o mínimo de pertences possível.

Como vemos nos casos relatados, o tempo de acampamento tem a ver com o tempo que de fato se passa debaixo da lona nos acampamentos e também com um know-how, com um saber, ou, em palavras nativas, com um conhecimento do modo como funciona o mundo das ocupações de terra.

Uma breve descrição da trajetória de Edesmaria no mundo das ocupações de terra talvez nos sirva para esclarecer melhor esse argumento.

Edesmaria chegou com uma leva de novos acampados no TSM, no começo de 2003. Rapidamente passou de nova a ser considerada uma das mais velhas de acampamento. Essa acampada, na sua chegada ao TSM, havia sido colocada no último grupo de barracas, com outros novos acampados; ela, tentando se diferenciar dos novatos, gostava de deixar explícito seu tempo de acampamento e repetir, em reuniões entre acampados e nas conversas cotidianas, que já tinha " $x$ anos de acampamento". A referência aos seus anos de acampamento sempre vinha acompanhada de relatos de aventuras, acontecimentos e dificuldades vivenciadas durante o tempo de acampamento.

Edes, em seu estado natal, Bahia, conforme mencionado no "Preâmbulo", havia passado por vários acampamentos organiza- 
dos pelo MST e instalados perto da cidade de Feira de Santana. Ela teve o primeiro contato com esse movimento por meio de parentes e conhecidos, que a convidaram para visitar pela primeira vez um acampamento.

Foi um dia de domingo, e, quando eu cheguei [no acampamento], eu vi que algumas pessoas ali precisava de mim; sabe quando você chega e vê: "Putz, essas pessoas precisam de mim". Aí comecei indo, comecei a me aprontar e a direção [do MST] chegou, e o pessoal me apresentou, né, e o pessoal de lá me apresentou como uma líder; e por aí começou, eu era a que coordenava para fazer arrecadação, para fazer a farmácia; e aí [...] minha vida era essa, mas nunca morei num acampamento.

(Edesmaria, Serra do Ramalho (BA), abril de 2006) ${ }^{7}$

Edesmaria se interessava sim por ganhar um pedaço de terra, mas não foi só esse desejo que a levou a começar uma peregrinação pelo mundo das ocupações de terra. Ela perambulou por vários acampamentos na Bahia, do Rosadinho para a Fazenda Asa Branca, depois para a Fazenda Santa Cruz e depois para Santa Lúcia realizando tarefas para o movimento (MST), como arrecadação, coordenação de grupos, trabalho de base. No entanto, naquela época, sua vida familiar havia se tornado, como ela me disse, um transtorno, e acabou desistindo do que ela chama o trabalho nos acampamentos. ${ }^{8}$ Todavia, a dedicação aos acampamentos lhe havia permitido se relacionar com políticos locais, deixando-lhe um ca-

7 Arrecadação é o termo nativo usado para descrever o trabalho que fazem os participantes dos acampamentos e militantes, cumprindo com suas obrigações, de ir para as ruas das cidades, para lojas, supermercados e instâncias de governo, pedindo principalmente alimentos para levar aos acampamentos.

8 Por causa da sua participação nos acampamentos e nas tarefas do movimento, Edes dedicava menos tempo à sua família, isso foi causa de brigas e desentendimentos com seu marido. É essa situação à qual Edes faz referência como transtorno. Para um aprofundamento da trajetória desta acampada e seu tempo de acampamento, ver Loera, 2010. 
pital de relações e permitindo-lhe então conseguir um trabalho em época de política. ${ }^{9}$ Porém esse emprego na política não resolveu, como ela pensava, seus problemas pessoais, muito pelo contrário, acabou sendo mais um complicador nas relações familiares. ${ }^{10}$

Depois que eu saí [do movimento], aquela confusão toda, aí eu comecei a trabalhar com o deputado José Assunção, que hoje é o prefeito da cidade, e meu ex-marido achou que eu tinha outro homem, porque eu trabalhava bem naquela época [...], eu trabalhava, era [...] época de política, eles compram cestas [básicas] [...]; e, [com] a seca no sertão, então o povo precisa de comida, e era doação; então pegava e levava pro sertão, eu [além do salário] tinha as diárias ainda; então ganhava muito bem, aí ele achava que eu tinha outro homem, até que um dia ele me deu um tapa e eu não pude descontar e larguei ele, saí de casa com 3 reais, e até hoje ele nunca mais me viu. (Edesmaria, Serra do Ramalho (BA), abril de 2006) ${ }^{11}$

A separação levou Edes a tentar a sorte em São Paulo, especificamente em São Bernardo, onde, havia vários anos, moravam alguns parentes que tinham encontrado, na migração para o sul, uma maneira de melhorar de vida. ${ }^{12}$ Alguns anos atrás, ela havia anima-

9 Como já foi tratado por Borges (2003) e Palmeira (2006), a "política” não constitui um domínio à parte, mas é vivida e pensada pelos agentes sociais como parte da vida social.

10 Nos acampamentos da reforma agrária, o "trabalho na política" não é uma expressão estranha, pelo contrário, faz parte do cotidiano das pessoas. Como menciona Barra, "é comum vereadores e deputados simpáticos ao MST contratarem acampados, assentados e militantes para trabalharem em suas campanhas e, até mesmo, executando trabalho de base para sua candidatura" (2007, p.21).

11 Edes separou-se em 1997 e, segundo os cálculos que ela mesma fez, dois ou três anos antes da separação, começou a participar nos acampamentos na Bahia.

12 Edes tem a mãe, uma irmã e um irmão morando em Bom Jesus (BA), o restante (quatro irmãos e uma irmã) mora no estado de São Paulo. Para uma discussão sobre as condições sociais que levam indivíduos a fazer investimentos materiais e psicológicos que tais deslocamentos exigem, ver Garcia Jr. (1990). 
do sua sobrinha e sua irmã para se instalarem num acampamento de sem-terra. Anos depois, o convite para ocupar lhe havia sido retribuído pela sua irmã. Edes passou alguns meses na casa de um irmão e depois na casa da irmã assentada em Sarapuí, no interior do estado. Foi então que surgiu a possibilidade de acampar novamente. A irmã falou com Roger, que era o coordenador do TSM, e pediu vaga para Edes no acampamento.

Para Edes, nesse momento, instalar-se debaixo da lona representou uma saída a curto prazo de uma situação emocional e econômica difícil, porém, por outro lado, também era a oportunidade de não depender mais dos parentes.

Sinceramente, na cidade não dá, você tem que ajudar a pagar água, pagar o telefone, o gás, então você fica [...], não tem como, é uma coisa muito difícil para você [...], na minha idade que eu estou hoje, não dá para você arrumar um trabalho decente, e na roça, não; eu só vim [para o acampamento] porque vou trabalhar, criar gado, plantar, aí vou ter com que me sustentar. (Acampamento TSM, Cajamar, abril de 2003)

Edes, tentando "sair" da cadeia de interdependências familiares, dependeu da sua irmã para entrar no acampamento, contraindo assim novas obrigações e inserindo-se em outra teia de interdependências dentro do acampamento. Para Elias (2005), a liberdade que cada indivíduo tem de fazer ou de decidir depende do tecido de interdependências (figuração) na qual está inserido. O indivíduo, para esse autor, acha uma margem de escolha individual, margem que, ao mesmo tempo, impõe limites à sua liberdade de escolha.

No TSM, Edes começou rapidamente a assumir algumas tarefas de responsabilidade dentro do acampamento, como coordenação de grupos e representante do grupo de mulheres, que era conformado por mulheres do acampamento que se reuniam uma ou duas vezes por semana para conversar sobre "a luta", e eram feitas outras atividades, como bordado e crochê. Como demonstra Comerford (1999), o termo luta pode adquirir diversos significados. Nesse 
contexto, de reunião de acampadas, "a luta" se referia especificamente a estar acampado.

Apesar de Edes ter participado em tarefas de coordenação em outros acampamentos da Bahia, foi só na sua chegada ao TSM, em São Paulo, que se deu conta de que seu tempo de acampamento podia render outros frutos que não só a terra.

Para Edesmaria, sua reinserção no mundo das ocupações de terra poderia criar as condições de possibilidade de fazer algo de que gostava: "trabalhar com o povo, mexer com o povo".

A dedicação ao acampamento (participação em atividades do movimento, levar famílias para novas ocupações, negociação para conseguir cestas e doações) abria-se então como uma alternativa de vida dentro do seu universo de opções.

Nos acampamentos, os velhos acampados, como Geni ou Edesmaria, geralmente são valorizados pelos novatos e muitas vezes os procuram para pedir conselhos, para consertar barracos e inclusive até para mediar negociações e brigas entre outros acampados. A partir dessas trocas e ajudas, consolidam-se relações de amizade e confiança e surgem outros vínculos fortes. ${ }^{13}$ Alguns acampados inclusive se sentem protegidos quando podem contar com alguém que tem mais tempo de acampamento.

Ilma, acampada no acampamento Famílias Unidas e amiga de Edesmaria, mencionava que era graças a Edes que ela continuava acampada. Ilma costumava ficar só nos finais de semana, no acampamento, e era Donizete, seu marido, quem de fato ficava acampado. Segundo ela, "à força de muita conversa", teria sido Edes quem a teria convencido de ficar, "de morar debaixo da lona”. Segundo Ilma, Edes é uma pessoa em que ela acredita e confia, pois tem "bastante tempo de acampamento".

Macedo (2005) mostra a importância da circulação de informações sobre a própria experiência da ocupação entre assentados

13 Ajuda é o termo nativo para designar as trocas que acontecem entre parentes e amigos que estão em outros estados do país, mas também aqueles que são assentados ou acampados. 
e acampados potenciais. Para o autor, essa circulação de informações se torna fundamental para mobilizar novas famílias que irão instalar-se debaixo da lona. Porém a circulação de informações e a troca de experiências sobre a vida nos acampamentos, entre velhos e novos acampados, são também fundamentais para que os novatos não só fiquem de fato nos acampamentos, mas aprendam o funcionamento do mundo das ocupações de terra e por sua vez o reproduzam. É graças a essa troca de experiências, em palavras nativas, de ensinamentos que também se consolidam laços de amizade, lealdade e confiança, criando-se as condições sociais necessárias para a continuidade dos acampamentos.

O caso de Zé Antônio é também esclarecedor a esse respeito. Conheci Zé Antônio no TSM em 2003, era um dos mais ativos nas tarefas de organização e coordenação da Secretaria do acampamento. E era também conhecido, entre os militantes da Regional de Campinas, por sempre levar bastante gente para os acampamentos. Ele, antes de acampar nesse acampamento, participou de outras ocupações da região, de fato, foi um dos que iniciaram o trabalho de base que criaria o TSM. Ele entrou no mundo das ocupações convidado por pessoas (militantes do MST) que conheceu no sindicato dos trabalhadores rurais de Limeira (SP). Em 2003 ele mencionava que, ao todo soma "mais de doze anos de acampamento". Nesses anos todos, Zé Antônio acampou em mais de dez acampamentos diferentes no estado de São Paulo. Como ele me disse, o objetivo dele não é ganhar terra para ele, mas assentar suas filhas. Para ele, o acampamento "é uma coisa de paixão mesmo".

Zé Antônio se considera militante do MST, no entanto, pelo que pude perceber, as pessoas que eram reconhecidas como militantes do MST pelos acampados eram as que atuavam diretamente na Regional de Campinas, militantes que por sua vez consideravam pessoas como Zé Antônio ou Edesmaria apoios do acampamento. Outras vezes, esses apoios eram chamados pelos acampados de militantes do acampamento, fazendo uma distinção com os militantes do MST, que para os acampados tinham um vínculo com a Direção Estadual ou Nacional do movimento. No caso específico do Zé An- 
tônio e inclusive da própria Edesmaria, eles eram conhecidos por alguns acampados do TSM como velhos de acampamento.

No caso particular de Zé Antônio, seus anos de acampamento lhe conferiam um status particular entre os acampados e era procurado pelos vizinhos de barraco e por novatos instalados em outros grupos de barracas para resolver todo tipo de situação. Ele me dera, um dia, um exemplo de um conselho dado a uns vizinhos que queriam melhorar seu barraco:

Falei: "Oh, gente, é o seguinte, é assim, assim e assim, lona preta, não tem jeito de fazer um barraquinho de madeira e tal?", não, porque é o seguinte: de repente nós está dentro do barraco e tem que desocupar ele ou ir para outra área, então, se você comprou madeira, você vai perder $80 \%$ do que você colocou lá. (TSM, Cajamar, junho de 2003)

Zé Antônio se orgulhava dos seus anos de acampamento, inclusive me relatou com orgulho que muitas famílias só continuavam acampadas por causa dele.

Seu Arlindo só veio para o acampamento porque eu vim; outro dia ele era para mudar para cá, mudou para outro barraco, aí recebeu a proposta do Chicão, e falou: "Não, recebi a proposta dos sem-terra e só quando seu Zé sair daqui e for para outro acampamento eu vou com ele para outro acampamento também". (TSM, Cajamar, julho de 2003) $)^{14}$

Zé Antônio, por ocasião da mudança de 50 famílias que sairiam do TSM para um acampamento na região de Andradina, fazia

14 A "proposta do Chicão", à qual Zé Antônio faz referência, era a proposta de formar outro acampamento dentro do próprio TSM. Proposta que partiu de um grupo de acampados, dentre eles um acampado chamado Chicão, que não concordava com o projeto da Comuna da Terra, modelo de assentamento para o TSM proposto pela militância do MST. Essa "proposta" foi tratada com detalhe em Loera (2006). 
questão de mencionar o quanto seus ensinamentos eram valorizados entre esses acampados: "O povo que foi [para Andradina] queria me levar junto para trabalhar com serviço lá, para estar ensinando eles porque não queriam outro mandando neles". Zé Antônio, inúmeras vezes também se fez de mediador entre as demandas de acampados e a militância do MST, principalmente quando havia problemas com a disciplina de alguns acampados e as formas de organização de tarefas no acampamento. ${ }^{15}$

O saber, a experiência dele acumulada no mundo das ocupações de terra, ou em palavras nativas, o tempo de acampamento colocavam Zé Antônio numa posição de destaque diante de outros acampados.

No entanto, os velhos acampados nem sempre são bem-vistos nos acampamentos. Para um militante do MST de Andradina, é difícil lidar com os vícios dos velhos acampados, para ele, é mais fácil trabalhar com os novatos, por isso prefere dar aos novatos cargos de responsabilidade no acampamento. Segundo esse militante, há velhos acampados que driblam a luta ou acabam se sentindo donos do acampamento. Em todo caso, para alguns militantes, os velhos acampados podem representar concorrência.

Para exemplificar essa afirmação, retomarei uma situação acontecida em 2003, no acampamento Dom Hélder Câmara.

Esse acampamento foi constituído por 50 famílias originárias do TSM e por novas famílias que tinham sido organizadas e convidadas em trabalho de base por militantes que haviam sido transferidos de uma regional para outra e tinham como tarefa principal coordenar o acampamento recém-formado e criar uma nova Regional do MST.

Diferentemente do TSM, o Dom Hélder Câmara, com mais de seis meses de existência, não havia recebido nenhuma visita de "fora" do acampamento e nem havia sido organizada nenhuma

15 Como já foi explicado anteriormente, na maioria dos acampamentos organizados pelo MST é obrigatório o cumprimento da chamada disciplina, o que significa cumprir certas tarefas coletivas dentro dos acampamentos e participar também das mobilizações organizadas pelo movimento, mas também tem a ver com um comportamento considerado adequado dentro dos acampamentos. 
mobilização; inclusive os próprios coordenadores do acampamento raramente apareciam, já que, segundo os acampados, dedicavam mais tempo à Regional do que ao próprio acampamento. Por essas e outras razões, os acampados mencionavam sentir-se isolados naquele acampamento. Os conflitos entre os acampados e as acusações de má coordenação não se fizeram esperar e o trabalho dos militantes começou a ser questionado.

Na percepção da maioria dos velhos acampados originários do TSM, não estava tendo o mesmo investimento físico e intelectual da militância para levar à frente esse acampamento, segundo eles, no Dom Hélder estavam parados. Essa expressão não só fazia referência ao fato de sentir que as negociações com o Incra para serem assentados não andavam, mas também porque não havia tantas atividades, tarefas, reuniões nesse acampamento, como acontecia no TSM.

Os acampados discutiam constantemente entre eles sobre como deveria ser a organização do acampamento. Aqueles que já tinham tempo de acampamento (ou seja, haviam estado acampados em outros acampamentos, haviam feito trabalho de base, participado de mobilizações e participado de grupos de coordenação e tarefas em outros acampamentos) concordavam que o Dom Hélder não estava funcionando como deveria e teriam que impor uma disciplina. Por outro lado, existiam novatos que não estavam dispostos a seguir a disciplina e a realizar certas tarefas dentro do acampamento.

Os conflitos e brigas entre velhos acampados e coordenadores no Dom Hélder eram cada vez mais recorrentes e com o acirramento dos conflitos também as relações entre os próprios acampados foram se deteriorando.

O grupo de acampados que discordava dos coordenadores do acampamento pediu a intervenção de militantes de outra regional não só para tentar mediar os conflitos, mas para repreender os coordenadores e tentar impor a disciplina no acampamento. Dois dirigentes da estadual do MST atenderam o chamado dos acampados e depois de uma reunião realizada em Castilho, com alguns velhos acampados, dentre eles Edesmaria, que haviam sido escolhidos 
como representantes do acampamento, os coordenadores deixaram a coordenação do Dom Hélder.

Como relata a própria Edes:

Tivemos um encontro em Castilho, e o Mário [coordenador do acampamento] queria brigar com nós; nós brigamos com Laís [militante da estadual], aí nós fizemos maior revolta dentro do acampamento, a gente apoiou o Tonho [outro militante] e me apoiaram também, ele era um cara legal, depois foi expulso do movimento, depois que eu fui embora, não sei por quê. E a gente fez uma revolução muito grande, né, porque o que é certo tem que ser certo, né; aí expulsamos, nós conseguimos expulsar Darlene e Mário e tirar do movimento, porque eu sei que alguém até hoje vai achar que eu sou muito faladeira e tudo mais [...], o MST mostrou que realmente é um movimento sério, que nem Laís, ela pode ter seus erros, tudo bem, mas é uma menina muito legal, e Laís foi lá com outro rapaz e expulsaram, tiraram eles do acampamento. (Bom Jesus da Lapa (BA), abril de 2006)

Outros militantes foram enviados para assumirem a coordenação do acampamento, mas nunca ficaram muito tempo. $\mathrm{O}$ acampamento chegou a permanecer meses sem militantes. Inclusive, nesse período, um grupo de velhos acampados chegou a assumir a coordenação do acampamento. Como uma das acampadas me disse: "quando o acampamento ficou sem dono, nós assumimos a coordenação".

Eles tentaram reproduzir a divisão de tarefas e disciplina aprendida no TSM e em outros acampamentos onde estiveram, e inclusive também tentaram marcar reuniões com representantes do Incra da região, para saber da situação da fazenda, mas foram desacreditados, inclusive por outros velhos acampados, que não só desejavam participar da coordenação do acampamento, mas também desejavam ter "verdadeiros militantes" no comando do acampamento.

O depoimento da Luzia, que era do grupo dos velhos acampados que coordenava o acampamento, é esclarecedor a esse respeito: 
Quando ficamos na coordenação [do Dom Hélder], teve um grupo que apoiou e teve um que não, o mineirinho, companheiro nosso, foi contra: "Por que o movimento escolheu nós?" Queria ele sozinho mandar, o movimento falou: "Não é assim". Nós trabalha é com grupo, né, o Tonho falou para ele: "Para de ser bobo, menino, não é assim que trabalha, nós trabalha em equipe”. [...] ele queria ser militante, e ele sozinho mandar [...], e o povo falava na cara nossa: "Esses não são militantes". (Acampamento Dom Helder Câmara, 2003)

Macedo (2003) relata uma conjuntura parecida à vivida no Dom Hélder, no caso estudado por ele, o acampamento Zé Pureza no estado do Rio de Janeiro. Segundo o autor, quando o acampamento completava um ano, "os sentimentos de falta de perspectiva, de informações e abandono por parte dos militantes tomaram conta dos acampados [...], o clima era de desânimo, e, ao mesmo tempo, nervosismo. Esse cenário de incertezas contribui decisivamente para a deterioração das relações pessoais e para o acirramento das disputas por espaços de poder no acampamento" (Macedo, 2003, p.121).

Os acontecimentos do Dom Hélder Câmara revelam a existência de relações de concorrência dentro do acampamento e também a complexidade da vida nos acampamentos, a importância dos velhos acampados na regulação dos conflitos e, principalmente, na reprodução da "forma acampamento".

Por outro lado, como já foi tratado por Rosa (2009 e 2011), um acampamento sem "movimento" é desacreditado pelos próprios representantes do Estado. Para fazer demandas ao Estado, é preciso não só ter um acampamento, mas um acampamento representado por um "movimento". No entanto, como vimos, também para os próprios acampados é necessária a presença nos acampamentos de dirigentes ou representantes de um movimento, eles não só se sentem protegidos, como também sentem que sendo representados por um movimento, estarão sendo "ouvidos" pelo Estado. 


\section{Moradores, acampados e apoios}

Tal como no TSM e no Dom Hélder Câmara, os velhos acampados do acampamento Famílias Unidas tiveram um papel fundamental na reprodução de tarefas e atividades no acampamento; no entanto, o tempo de barraco nesse acampamento vivenciava-se de maneira diferenciada e era de fato medido e contabilizado dependendo da condição e situação dos indivíduos no acampamento.

Para entender o argumento anterior, é preciso remontarmos ao processo de constituição e conformação desse acampamento, assim como aos principais acontecimentos que resultaram em uma divisão das famílias e de uma forma particular de organização.

A ocupação que deu vida a esse acampamento foi realizada em dezembro de 2003 na região de Andradina (SP), na qual participaram mais de 80 famílias organizadas por lideranças do Sindicato dos Trabalhadores da Agricultura Familiar de Andradina (Sintraf). Algumas dessas famílias provinham de outros acampamentos, outras eram famílias de novatos originárias de fazendas, pequenas vilas rurais ou de cidades próximas. ${ }^{16}$ Segundo depoimentos de acampados e dos coordenadores do acampamento, algumas famílias, após meses de acampamento, estavam insatisfeitas com a maneira como o acampamento estava sendo organizado pelas lideranças do Sintraf. Essas famílias, conforme me relataram, foram caçar um movimento, ou seja, decidiram conversar com militantes do MST da região para que os apoiassem e levassem à frente o acampamento. Daí surgiu o primeiro racha. Algumas famílias ficaram acampando sob a bandeira do Sintraf, outras passaram a acampar sob a bandeira do MST. Nas palavras de uma acampada, "ficaram dois Sintraf", ou seja, dois movimentos dentro do acampamento. ${ }^{17}$

16 Segundo relatos de velhos acampados que participaram da ocupação da Fazenda, mais da metade das famílias provinham de outros acampamentos da região, o restante eram novos acampados.

17 Foge dos objetivos deste trabalho reconstruir de maneira detalhada e problematizar aquele primeiro racha do acampamento, mas, apoiando-me nos relatos dos acampados, posso inferir que as diferentes famílias que compunham o 
Depois de alguns meses, alguns acampados que contavam já com certo tempo de acampamento ficaram à frente da organização das famílias que ainda estavam sob a bandeira do Sintraf e, como um acampado me disse: "não aceitaram mais a bandeira deles" e decidiram adotar outra sigla, OLPT (Organização de Luta pela Terra). ${ }^{18}$

O acampamento, um ano depois da sua fundação, encontrava-se dividido em duas bandeiras, OLPT e MST, e havia dobrado seu tamanho, outras famílias das imediações e de cidades próximas passaram a se instalar "na Fazenda". Devo mencionar que a dinâmica do acampamento Famílias Unidas em relação às entradas e saídas de novos e velhos acampados não era diferente de outros acampamentos do estado. Havia uma grande circulação e renovação de pessoas. Desde sua criação, em dezembro de 2003, inúmeras famílias saíram e novas se integraram, mas, nesse acampamento em particular, por causa principalmente da sua proximidade com as cidades de Castilho e Andradina, a circulação de pessoas no dia a dia entre acampamento e cidade era maior do que em outros acampamentos, como o Dom Hélder, por exemplo, que se encontrava a mais de 40 quilômetros da cidade mais próxima, o que dificultava a circulação cotidiana dos acampados entre acampamento e cidade. Muitas das famílias que se instalavam no acampamento Famílias Unidas montavam um barraco, mas não moravam no acampamento, já que trabalhavam e mantinham uma casa em cidades próxi-

acampamento decidiram ficar sob uma ou outra bandeira (Sintraf ou MST), obedecendo a uma série de lealdades e compromissos com aqueles que lideravam ambos os grupos. Outras situações semelhantes foram analisadas com detalhe por Brenneisen (2003) e Loera (2006).

18 Nino, anos atrás, havia sido assentado na região de Andradina, na Fazenda Timboré, separou-se da esposa e ambos decidiram vender o lote. Meses depois ele foi acampar novamente. Durante os anos de acampamento, antes de ser assentado, Nino havia participado de maneira ativa com militantes do MST. Segundo ele, por conhecer e não concordar com as formas de atuação da militância desse movimento decidiu, no contexto do racha do acampamento Famílias Unidas, acampar sob outra bandeira que não a do MST. 
mas. Essas famílias geralmente iam para o acampamento durante os finais de semana ou a cada 15 dias, quando aconteciam as assembleias. Esse tipo de acampado intermitente é chamado de andorinha. Essa categoria de acampados foi também identificada por outros autores (Macedo, 2003; Barra, 2007) nos acampamentos por eles estudados.

A presença dos chamados andorinhas sempre havia sido tolerada no acampamento, inclusive, a maioria dessas famílias intermitentes, como uma forma de compensar o tempo que não passavam no acampamento, dava o chamado apoio de barraco para manter a vaga no acampamento. ${ }^{19}$

$\mathrm{Na}$ maioria dos acampamentos, não se pode montar uma barraca sem ter negociado ou pedido antes uma vaga. São duas coisas separadas: ou se negocia ou se pede uma vaga. Podia acontecer de, antes de negociar a vaga, conseguir ou comprar um barraco de alguma pessoa que desistiu ou mudou do acampamento; no entanto, não se pode simplesmente instalar-se nele sem antes ter sido liberada uma vaga.

No final de 2005, com a chegada ao acampamento de um grupo de "novos velhos acampados", dentre os quais se encontrava Edes, a forma de organização e de gestão do acampamento começou a ser questionada.

Esses acampados contavam com um currículo de ocupações e acampamentos e desqualificavam a prática do apoio de barra-

19 Segundo relatos de acampados que passaram por vários outros acampamentos da região, o pagamento de apoio de barraco começou num acampamento montado vários anos atrás, na Fazenda Cafeeira, organizado por pessoas vinculadas ao Sintraf. No entanto, essa prática foi difundida nos acampamentos da região organizados por outros movimentos. Não consegui saber com exatidão qual era o critério da variação do pagamento do apoio de barraco, alguns acampados só mencionaram de maneira geral que os mais antigos pagavam menos. $O$ apoio de barraco como veremos adiante também era conhecido como taxa ou apoio, o que permitia ter uma espécie de fundo de gestão para administrar as despesas dos acampamentos e viagens de representantes dos acampados a entidades como Incra e ITESP em outras cidades e capital do estado. 
co, argumentando precisamente sobre a importância do tempo de acampamento. Para esse grupo, a presença do acampado ou de algum representante do acampado na barraca era indispensável para legitimar a pretensão de terra. Afinal é o barraco que "indica" a "pertença" ao acampamento e é por meio dele que sé é candidato à reforma agrária. A ênfase, como menciona Smircic (2000), é a importância atribuída ao ato de acampar. Como mostra Loera (2006), não só a barraca simboliza o "pertencimento" ao acampamento, mas, para a maioria dos acampados, o tempo passado debaixo da lona faz parte da "lógica do merecimento" associada a um discurso do sofrimento. ${ }^{20}$ Aquele que passa mais tempo debaixo da lona -e, portanto, sofre mais - considera sua luta mais legítima com respeito àqueles que têm menos tempo de lona preta.

Algumas pessoas, do grupo dos "novos velhos acampados", para o desgosto de lideranças do MST do acampamento, se deram à tarefa de realizar uma espécie de trabalho de base dentro do próprio acampamento, ou seja, um trabalho de convencimento para que as famílias ficassem debaixo da lona. Para as lideranças do MST, ao impor a obrigação de morar, as pessoas iriam desistir do acampamento e este se veria esvaziado. Lembremos que, tanto para acampados como para dirigentes dos movimentos, o número de acampados é proporcional à pressão que se exerce para obter as terras demandadas ou outros benefícios públicos outorgados pelo Estado.

Edes, por causa do trabalho realizado, relatava com orgulho o fato de ter convencido várias famílias para que realmente acampassem. Ilma foi uma das que passaram a morar no acampamento, ela acionava a "lógica do merecimento" para justificar sua decisão:

20 Brenneisen (2003) identificou em um assentamento no oeste do Paraná o que ela chama de "pedagogia do sofrimento". Já Macedo (2003) faz menção a uma "ética do sofrimento". Caume, por outro lado, identificou no assentamento, lócus da sua pesquisa no Rio grande do Sul, a existência de um discurso do sofrimento, "os acampados utilizam como arma discursiva o relato da luta e do sofrimento no período de acampamento para afirmar o assentamento como conquista do acampamento" (2002, p.174). 
“Esse negócio de cobrar apoio... eu não acho justo as pessoas cobrarem para não ir no barraco; se quiser a terra, tem que também sofrer no barraco". Nesse contexto, a maioria dos andorinhas, vendo sua vaga no acampamento ameaçada, começou a fazer uma série de acusações e qualificar como morcegos aqueles que ficavam debaixo da lona. Nessa conjuntura, muitos dos acampados intermitentes que estavam sob a bandeira do OLPT passaram para o grupo do MST, em que não se exigia morar no acampamento.

Macedo (2003), na sua etnografia sobre o acampamento Zé Pureza, mostra como muitas das disputas e dos rachas nesse acampamento aconteciam entre residentes e andorinhas e tinham como pano de fundo certos critérios de legitimidade, dentre eles uma ética do sofrimento, que em maior ou menor grau, é o que consideravam, dava mais legitimidade àquele que de fato ficava no acampamento. Já Barra descreve o caso de famílias do TSM, que mudaram para um acampamento na região de Ribeirão Preto (SP), no qual já existia outro acampamento também do MST, o Mário Lago, e chama a atenção para o surgimento de problemáticas nas relações interpessoais, na medida em que os acampados não só vivenciam uma mudança espacial, mas têm que conviver de um dia para outro com novas regras de organização do espaço e das relações, e ainda têm que lidar com a separação do grupo com o qual convivia fazia anos e enfrentar outro grupo, "possuidor de uma outra história que habitava aquele espaço há mais tempo com sua maneira de pensar o movimento e a si mesmo" (2007, p.10).

Segundo o coordenador do MST do acampamento Famílias Unidas, Nino, coordenador do grupo da OLPT, foi um dos responsáveis pelo racha, por ter-se posicionado a favor da exigência de morar debaixo da lona. Para esse militante, "O Nino quebrou o acampamento, fez a luta diminuir, ele colocou a regra de morar, de que não podia trabalhar. Foi nesse momento que o povo todo veio pro meu lado [do MST]". Segundo ele, as pessoas que trabalhavam na cidade não podiam ficar todos os dias no acampamento e foi a razão principal de terem saído "do grupo do Nino". 
O grupo dos "novos velhos acampados" teve um papel fundamental na criação de uma nova forma de organização e configuração do acampamento. Nesse contexto de disputa por legitimidade e merecimento, surgiu uma nova divisão das famílias: moradores ou acampados versus andorinhas, que começaram a ser chamados de apoios em referência ao pagamento do apoio de barraco.

Nino e o grupo de acampados próximos a ele, dentre eles os "novos velhos acampados" decidiram mudar o nome do movimento de OLPT para MTR (Movimento do Trabalhador Rural), um dos motivos da mudança deveu-se à inconformidade dos acampados com o nome do grupo; segundo Nino, "o povo não aceitava OLPT... queriam que fosse movimento". Como foi mencionado anteriormente, os acampados estão cientes da importância de serem representados por um movimento. No caso particular de um grupo de famílias do acampamento Famílias Unidas, os acampados interpretaram essa necessidade inclusive de maneira literal; para eles, uma "organização" não tem a mesma legitimidade perante o Estado que um "movimento". O grupo adotou então a sigla MTR. Segundo Nino, ele teve a ideia de mudar, pois viu na internet que esse movimento havia nascido "lá no nordeste, em Pernambuco", e que era "bastante conhecido". ${ }^{21}$

$21 \mathrm{Na}$ internet há um movimento que aparece com a mesma sigla do MTR, o Movimento dos Trabalhadores Rurais, no plural. Entretanto, não há nenhuma referência sobre a origem no estado de Pernambuco. No entanto, o MTR, no plural, aparece como um dos movimentos que realizam mais ocupações no estado do Paraná. Também outro MTR está referenciado na página do Movimento Nacional de Produtores (MNP), <www.mnp.org.br>, em que aparece uma lista de 20 "áreas invadidas" por esse movimento desde 1999 até 2001, a maioria delas em municípios de Mato Grosso do Sul (agradeço ao professor Fernando Lourenço por ter me alertado sobre a existência dessa informação). Nino, coordenador do MTR do acampamento Famílias Unidas, não tinha conhecimento de outras áreas ocupadas sob a sigla do MTR na região (lembremos que esse acampamento estava localizado em São Paulo, a tão somente 40 quilômetros da fronteira sul mato-grossense), o que me leva a argumentar que o MTR do Mato Grosso do Sul é outro movimento. 
Figura 1 - Acampamento Famílias Unidas: três siglas (Sintraf, OLPT e MTR) indicam mudanças de nome impressas em um mesmo barraco ${ }^{22}$

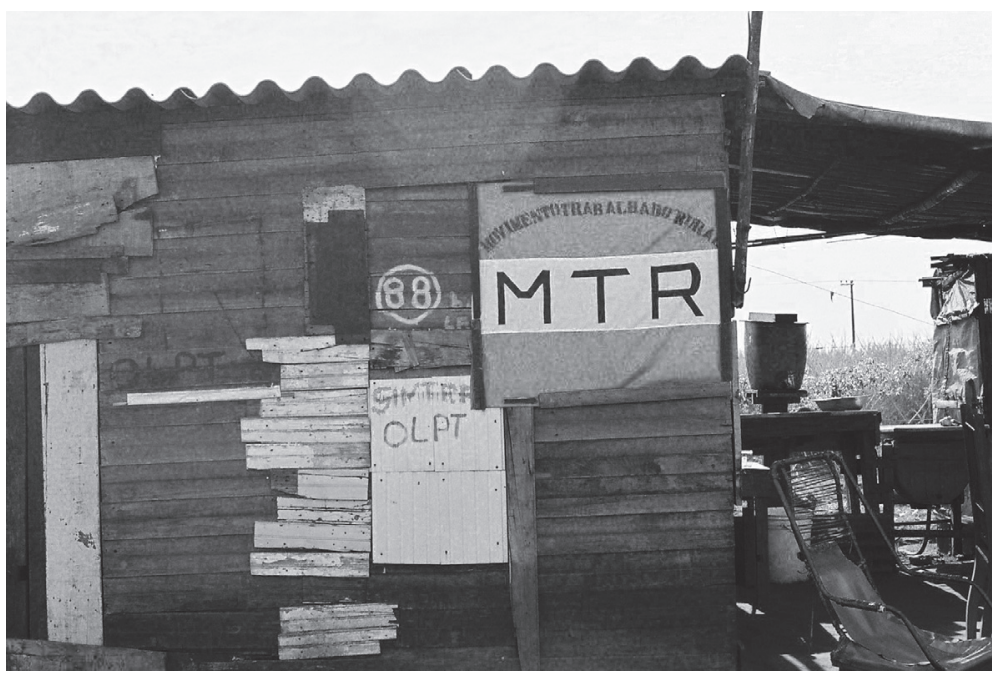

Foto: agosto de 2007

A mudança de siglas veio acompanhada com uma mudança de regras e com outra maneira de organizar o acampamento.

Por um lado, para Nino, que se tornou coordenador do MTR, morar no acampamento converteu-se numa regra para todo aquele que quisesse montar uma barraca sob a bandeira desse movimento; já, para o coordenador do MST, morar no acampamento continuava sem ser uma obrigação, mas foi estipulado que aquele que desejasse ser candidato à reforma agrária e não pudesse morar no acampamento devia cumprir regra de dois, três ou quatro dias. $\mathrm{Ou}$ seja, aquele que conseguisse uma vaga no MST, no acampamento, devia especificar quantos dias da semana poderia ficar nele.

Para os novatos, a vaga para montar barraca devia ser negociada com Nino, coordenador do MTR, ou com o coordenador do MST,

22 Todas as fotos que aparecem no texto foram tiradas por mim em diferentes lugares e datas, que estarão especificados ao pé da foto. 
dependendo do tipo de vaga que se quer: de morador ou de apoio. Em geral o acampamento Famílias Unidas era bastante procurado por pessoas que desejavam ter barraco nesse acampamento, como morador ou de apoio; toda semana havia pessoas que passavam perguntando se tinha vaga. Segundo Nino, o acampamento era procurado por causa da sua localização, perto da cidade. Ele me explicava que, muitas vezes, os novatos, sem conhecer como funciona o acampamento e achando que a vaga se dava de maneira automática, negociavam primeiro um barraco. Ele me relatou uma ocasião que a irmã de um que já estava acampado, desesperada para ter uma vaga para morar, acabou comprando um barraco, mas Nino não tinha mais vaga e falou para ela: "caça uma vaga nem que for do MST, porque senão vai ficar difícil você ficar”.

Algumas pessoas argumentavam que preferiam instalar seu barraco do lado do MST, já que tinha a opção de não morar e portanto não passavam pelo "sofrimento" debaixo da lona e, por outro lado, acreditavam que, estando do lado do MST, poderiam conseguir as terras mais rapidamente, pois circulava uma crença entre acampados e futuros acampados de que o MST era mais organizado e mais influente e, por ser um movimento mais (re)conhecido, seus dirigentes podiam conseguir mais rapidamente a desapropriação das terras. ${ }^{23}$ De fato, no caso específico do acampamento Famílias Unidas, havia acampados que esperavam meses antes de conseguir uma vaga do MST.

Esse foi o caso de Teresa, que esperou mais de seis meses. Teresa, em 2009 fazia quase dois anos que estava acampada com seus dois filhos. Ela era casada e morava na cidade de Castilho. Os pais dela, Joaquim e Luzia, já contavam com mais de três anos de acampamento. Teresa decidiu acampar também, depois que se separou

23 Faço referência à crença como conceito sociológico. Partilho o argumento de autores como Weber (1992) e Bourdieu (2004), para os quais a crença é socialmente produzida. 
do marido, mas teve que esperar por uma vaga do lado do MST. A vaga foi aberta na ocasião de uma reocupação da Fazenda, em novembro de 2007. Apesar de ter tido a oportunidade de conseguir uma vaga do Nino, ela queria estar junto dos pais, que acampam do lado do Biro (MST). Teresa não havia acampado antes, mas, por relatos de assentados e outros acampados com quem tinha contato na cidade, inclusive antes de seus pais acamparem, tinha ouvido que os acampamentos do MST eram bem organizados, e mais, preferia uma vaga do MST, pois era o movimento do qual já tinha uma referência.

Devo mencionar que os dois coordenadores (do MTR e do MST) fizeram o que eles chamavam de um acordo de cavalheiros depois da última reocupação da Fazenda, para não abrir novas vagas no acampamento, pois, segundo Biro, quando a fazenda fosse desapropriada, "haveria lotes para no máximo 170 famílias". Mais ou menos o número de famílias acampadas no acampamento Famílias Unidas em 2009. No acordo também foi combinado que se houvesse vagas remanescentes no assentamento estas seriam divididas em partes iguais entre os movimentos e só poderiam ser indicadas para essas vagas pessoas que, de fato, estavam acampadas no momento da indicação. ${ }^{24}$

Portanto, com esse acordo de cavalheiros, as vagas eram dadas somente em caso de desistência de outro acampado. Também, por causa desse limite de vagas, havia pessoas na fila, esperando alguma vaga ser liberada. Esse foi o caso de dona Leo, por exemplo, que esperou um pouco mais de três meses em outro acampamento, na Fazenda Brinco de Ouro, até abrir uma vaga no acampamento Famílias Unidas.

Uma vez que a vaga é dada, a pessoa instala seu barraco, podendo então ser acampado ou "manter barraca no acampamento". É importante mencionar que hoje em dia, em vários acampamentos

24 A prática da indicação será tratada com detalhe no último capítulo. 
do estado de São Paulo, o termo acampado é usado para designar exclusivamente aqueles que, de fato, moram no acampamento. ${ }^{25}$

Algumas famílias que desejavam ter uma barraca do lado do MST, no acampamento, encontraram um mecanismo para não ficar na fila, esperando uma vaga. Se primeiro era liberada uma vaga do MTR, o acampado pedia a vaga e instalava a barraca sob a bandeira do MTR, ficava um ou dois meses acampando e, quando abria uma vaga do lado do MST, mudava. Nino, coordenador do MTR, para evitar esse tipo de situação, decidiu tomar algumas providências e pôr várias regras no papel: para começar, aquele acampado (do MTR) que decidisse sair do acampamento devia assinar um papel-padrão, declarando que estava saindo voluntariamente do acampamento, isso para ter uma prova de que o acampado saiu sem nenhum tipo de constrangimento ou coação por parte do coordenador, e também porque, ao assinar, o acampado aceita que não poderá concorrer a um lote na fazenda em disputa. Por outro lado, os novos acampados também tinham que assinar um papel se comprometendo a não mudar para o grupo do MST e, caso o fizessem, era preciso conseguir uma vaga do MST.

Veja cópia dos formulários que deviam ser preenchidos:

25 O termo acampado se tornou uma categoria oficial nos cadastros do Incra e designa todos aqueles que têm barraco num acampamento como candidatos a um lote de terra. No entanto, durante a pesquisa percebi que, em alguns acampamentos, nem todo mundo que tem barraca é considerado acampado. Conforme mencionado, em acampamentos do oeste do estado de São Paulo, o acampado é somente aquele que, de fato, mora no acampamento e não é considerado dessa maneira, por exemplo, o "morador de final de semana", ou andorinha. Feito esse esclarecimento, no decorrer do texto, ao fazer referência de maneira geral aos participantes dos acampamentos, usarei o termo acampados (sem itálico) e, quando fizer referência ao termo nativo, que faz referência aos que de fato moram nos acampamentos, deixarei o termo em itálico. 


\section{ACAMPAMENTO FAMÍLIAS UNIDAS DA FAZENDA}

Fundando Em 21/12/2003

Portador da Cédula (a) de identidade, RG sob o
número
e inscrito (a) no CPF, sob o $\mathrm{n}^{\circ}$

Estou desistindo de livre espontânea vontade do Acampamento Famílias

Unidas , da fazenda localizada na rodovia S.P.V- - no $\mathrm{Km}$ no município de estado de São Paulo. Filiado pelo M.T.R (Movimento Trabalhador Rural).

Declaro para os devidos fins de direitos e efeitos legais que não posso concorrer a um Lote na Fazenda por motivos de estar abandonando o Acampamento.

Por estar de pleno acordo, afirmo presente ao coordenador e duas testemunhas.

\section{Coordenador}

Testemunha

\section{Testemunha}

de de 


\title{
ACAMPAMENTO FAMILIAS UNIDAS DA FAZENDA
}

\author{
PENDENGO - CASTILHO - SP
}

FUNDADO EM 21/12/2003

\section{DECLARACÃO}

Eu

Portador da cédula de identidade sob o $n^{\circ}$ e inscrito no CPF sob o ${ }^{\circ}$

Afirmo que estou de livre espontânea vontade de ficar acampado no Acampamento Famílias Unidas da Pendengo.

Filiados pelo M.T.R (Movimento Trabalhador Rural) na qual não posso mudar para o grupo do M.S.T .

Caso eu queira passar para o grupo do M.S.T tem, que ser numa vaga deles, pois a minha vaga no M.T.R será colocada uma outra família, estando de pleno acordo Afirmo Presente.

ACAMPADO

COORDENADOR

TESTEMUNHAS

TESTEMUNHAS

Castilho, de de 200 
No acampamento Famílias Unidas e, independentemente sob que bandeira que se tinha uma barraca, o tempo que o morador ou o apoio passava no acampamento era medido pelo caderno de pontos: um caderno no qual em todas as folhas era colocado o nome da pessoa e a regra, ou seja, os dias que essa pessoa devia ficar no acampamento. Assim, aqueles, por exemplo, que cumpriam regra de dois dias por semana ou eram moradores de final de semana deviam acumular em um mês um total de oito assinaturas no caderno, aqueles que cumpriam regra de três dias deviam contabilizar no final do mês um total de doze assinaturas, e assim por diante. No final do mês, o coordenador dava uma olhada no caderno e dessa forma ficava sabendo quem estava e quem não estava cumprindo regra. ${ }^{26} \mathrm{O}$ caderno de pontos do MST ficava nas mãos de alguém de confiança do coordenador, geralmente um morador. Os que cumpriam regra passavam no barraco daquele que estava com o caderno e assinavam. Segundo o coordenador do MST, que não morava no acampamento, ele não gostava de deixar o caderno muito tempo com a mesma pessoa e fazia "rodízio do caderno de pontos" com o objetivo de evitar vícios entre acampados, por exemplo, acordos que podiam ser estabelecidos para driblar o cumprimento efetivo da regra. Ele também gostava de delegar esse tipo de responsabilidade aos novatos; segundo ele, era uma estratégia para fazer as pessoas participarem de alguma atividade que atinja o coletivo, "a ideia é sempre delegar tarefa, dar responsabilidade, que assim a pessoa entra na luta”.

Já o caderno de pontos do MTR ficava nas mãos dos coordenadores Nino e Maria (sua esposa), que morava no acampamento. Nesse caso, os acampados sob a bandeira do MTR deviam ter um mínimo de quatro assinaturas por semana, mas o desejado é que assinassem todos os dias. Uma das tarefas cotidianas dos coordenadores era visitar os acampados para coletar as assinaturas ou, como pude também observar, esperar no barraco da coordenação, para que as pessoas assinassem. É claro que, como em qualquer mundo

26 Os apoios que mantinham barraco também eram chamados pelos moradores de os que cumprem regra. 
social, há exceções à regra e havia acampados que não cumpriam com o mínimo de quatro dias. No entanto, estabeleciam acordos com os coordenadores e compensavam o tempo de barraco de outra maneira. Nino, por exemplo, estabeleceu um acordo com quatro famílias do acampamento. Segundo ele, essas famílias fundadoras do acampamento, velhas de acampamento, estavam numa situação econômica difícil e queriam ficar fora do acampamento durante alguns meses para poder trabalhar, mas não queriam perder sua vaga. Como compensação pelo "tempo" que ficariam fora do acampamento, essas famílias colaborariam com uma taxa mensal de despesas de todas as famílias do acampamento (60 famílias do MTR) (5 reais por família). Tomando como inspiração o clássico Malinowski (2003), diríamos que as regras, nesse caso, se adaptaram à vida.

Assim, o controle da presença dos acampados era plasmada no caderno de pontos, um dispositivo que serve para levar um controle do tempo, mas não de um tempo qualquer, do tempo que se passa no barraco e especificamente no acampamento. Os acampados acreditam que o cumprimento da regra e o tempo de barraco contabilizado no caderno de pontos, de alguma forma, contaria na hora de pleitear uma vaga num assentamento.

Outros autores (Borges, 2003; Macedo, 2003; Quirós, 2006) observaram em outros contextos etnográficos a existência de dispositivos (listas) que servem para indicar quem receberá benefícios por parte do Estado. Essas listas, além de enumerar ou classificar quem receberá os benefícios, revelam também a existência de uma hierarquia, de um status diferenciado no interior dos grupos estudados. As listas identificadas por Borges entre os moradores de uma cidade satélite de Brasília são dispositivos que mostram a relação que se tem com o Estado, no sentido de quem é mais apto para se tornar beneficiário dos bens disponibilizados, entre eles, o de maior valor é o lote. No acampamento estudado por Macedo, no Rio de Janeiro, foi estabelecida uma série de critérios "que consistiam num sistema de classificação das famílias acampadas que estabelecia uma ordenação para o assentamento, caso não houvesse parcelas de terra para todas as famílias em um primeiro momento" (2003, p.143). Nas listas que ficavam afixadas numa barraca localizada no centro do acampamen- 
to, era plasmada uma hierarquia das famílias, já que eram ordenadas segundo o cumprimento dos critérios. Já Quirós, na sua etnografia sobre participantes dos movimentos de desocupados em Buenos Aires, menciona a existência de listas nas sedes dos movimentos que classificam as pessoas segundo o número de mobilizações nas quais participam e os benefícios recebidos em forma de cestas básicas disponibilizadas pelo Estado, proporcionais à participação.

Esses dispositivos e principalmente aqueles indivíduos que por meio deles têm o controle da distribuição dos bens, sejam lotes, créditos, cestas básicas etc., podem ganhar um status diferenciado no acampamento, no movimento, no bairro, na cidade, em suma, nos universos sociais por onde circulam.

Rosa (2009) retoma a trajetória de Fernando, uma liderança do mundo das ocupações de terra em Pernambuco. A inserção de Fernando no mundo dos movimentos lhe permitiu vincular-se a partidos e políticos locais, assim como a representantes do Incra. Fernando, como relatado pelo autor, foi escolhido pelo Incra para distribuir cestas básicas aos trabalhadores rurais da sua cidade, na época de entressafra. Essa tarefa o colocou numa posição diferenciada, de destaque na sua cidade e conferiu-lhe "um tipo específico de poder, o de incluir pessoas nas demandas por terras e cestas básicas" (Rosa, 2009, p.173).

No caso do acampamento Famílias Unidas, o caderno de pontos era um dispositivo local que servia para classificar - tendo como critério o tempo de barraco - os concorrentes a um lote de terra, mas também mostrava a heterogeneidade de grupos e categorias de acampados: os que cumprem regra, moradores de final se semana, apoios, acampados ou moradores. Por outro lado, o caderno de pontos confere certo prestígio, status para o seu guardião, principalmente entre os acampados sob a bandeira do MST - o portador do caderno se tornava uma espécie de guardião do tempo dos outros, é aquele que ao final do mês poderia dizer se o tempo de barraco foi cumprido e por quem foi cumprido. O guardião do caderno era também alguém que se diferenciava de outros acampados por ter a confiança do coordenador e, principalmente, por saber escrever, um conhecimento também valorizado entre os acampados, um elemento de distinção. 
Feix (2001), no seu estudo sobre trabalhadores rurais assentados no Mato Grosso, menciona que "o domínio das letras é um recurso social fundamental" para o MST atingir um dos seus objetivos principais: "a formação técnica e política dos trabalhadores" (2001, p.169), objetivo difícil de conseguir sem esse recurso. ${ }^{27}$

\section{Barracos e barracos}

O barraco é um símbolo de extrema importância entre os acampados e sempre surge como tema nas conversas cotidianas: fulano quer mudar de barraco, o barraco rasgou, fulano fez outro cômodo no barraco, fulano desmanchou o barraco, o barraco de fulano é bom; e, sempre, o barraco aparece como prova das aventuras e dificuldades de uma ocupação ou do tempo passado num acampamento.

Zé Antônio, do TSM, guardava com zelo um álbum de fotografias dos diversos acampamentos onde esteve e orgulhoso fazia questão de comentar aquelas fotografias em que aparecia montando a estrutura de um barraco.

Já dona Leo, acampada no Famílias Unidas, não só gostava de mostrar a cada convidado que chegava para visitá-la todos os remendos feitos no barraco, mas também não se cansava de relatar com todos os detalhes eventos trágicos que tinham marcado sua vida no acampamento, eventos nos quais o barraco era o protagonista central. ${ }^{28}$

Em um dos relatos de dona Leo, ela descreve o dia em que a maioria dos acampados estava participando de uma mobilização e, como havia ficado no acampamento, viu, sem poder fazer nada, "como um vento fortíssimo levava embora os barracos dos vizinhos". O outro evento relatado por dona Leo é a tragédia do barraco do seu filho. Ela

27 Feix (2001) analisa indicadores socioeconômicos para tentar estabelecer um perfil dos assentados. Um desses indicadores é o grau de escolaridade. Segundo o autor, quase $80 \%$ dos trabalhadores se situam na faixa entre nenhuma escolaridade e conclusão da 5 a série.

28 Como veremos adiante, o tempo de barraco também se demonstra com a dedicação ao barraco. Os remendos de dona Leo são uma prova desse "tempo". 
relatava com emoção a solidariedade do coordenador e dos vizinhos do acampamento "quando o barraco pegou fogo" e seu filho "perdeu tudo o que tinha". Segundo ela, [os vizinhos e os coordenadores] "correram atrás de colchão, de roupa para as crianças, até cama conseguiram, montaram um barraco novinho”. Tempo depois descobriram que o incêndio tinha sido provocado pela sua nora, que, de acordo com ela, "não se conformava com o que tinha, queria ganhar tudo novinho".

Já uma vizinha de barraco de dona Leo, que fazia parte dos apoios e cumpria regra de três dias, discutia com sua vizinha o descuido do seu barraco e justificava que, apesar de não ser um dia de cumprir regra, estava ali no acampamento precisamente para arrumar e concertar o barraco. As vidas são narradas através do barraco.

É precisamente por causa dessa importância dada ao barraco que alguns acampados conseguem acumular certo capital simbólico, principalmente por terem um tipo específico de conhecimento, também bastante valorizado no mundo das ocupações de terra: saber montar barraco.

No acampamento Famílias Unidas, esse tipo de conhecimento era um bem precioso, inclusive um acampado podia, como mencionavam alguns, "ganhar o pão com esse serviço", montando barracos.

Zélia, acampada desse acampamento, me relatava que, assim que chegou ao acampamento, contratou um acampado "bom de fazer barraco", para que montasse o dela.

O preço cobrado por montar barraco podia variar e parecia depender principalmente: de para quem é feito o serviço, ou seja, se é amigo, parente, conhecido; e, de que aquele que faz o serviço seja reconhecido.

A habilidade e reputação como bom de fazer barraco, acreditava-se, não só tem a ver com uma característica própria da pessoa, de ter destreza ou de "levar jeito" para realizar esse tipo de tarefa, mas adquiria-se com o tempo de barraco, com a experiência acumulada debaixo da lona. ${ }^{29}$

29 Para buscar exemplos em outros contextos etnográficos sobre a relação entre conhecimento e reputação, ver Haviland (1977) ou ainda Comerford (2003). 
Maranhão, acampado também no Famílias Unidas, me explicava que só podia ser bom de fazer barraco aquele que já havia passado "um bom tempo debaixo da lona", para ele, somente com o tempo de barraco se aprendia, por exemplo, que tipo de material é melhor. "A madeira", explicava-me, "dura mais do que o bambu, o bambu a gente cata em qualquer lugar, no mato, a madeira não, a gente tem que comprar". No entanto, na hora de mudar [de lugar, de acampamento], o bambu é mais difícil de desmontar. "O jeito de botar a lona”, segundo ele, também era fundamental para um barraco suportar chuva e vento forte.

Para esse acampado, não só o conhecimento sobre o material que deve ser utilizado era importante na hora de fazer barraco, mas também "o jeito de montá-lo".

Um barraco podia, então, ter mais valor do que outro não só pelo material com o qual foi construído, mas também pela maneira como foi construído e por quem. Em outras palavras, barracos estariam "impregnados" de um saber particular, do conhecimento do bom de fazer barraco ${ }^{30}$ Essa particularidade e distinção entre barracos era explicitada pelo próprio Maranhão, que mencionava: "Aqui no acampamento têm barracos e barracos".

Como explicitado em Loera (2006), os barracos são percebidos como tendo donos e são objeto de transações entre vizinhos, parentes e amigos no acampamento. Mas, hoje em dia, no mundo das ocupações de terra, o barraco representa também um capital para o acampado. Dependendo do acampamento, os acampados podem investir um pouco mais num barraco bem-feito, com materiais melhores, sabendo que, caso decidam sair ou mudar de acampamento, um barraco bem-feitinho pode ter mais valor e, como consequência, pode ser mais bem vendido.

Por outro lado, há barracos que podem valer mais e serem vendidos mais caros, não só porque o "dono do barraco" investiu mais

30 Essa afirmação é inspirada na análise realizada por Mauss (2003) da noção maori de hau. $\mathrm{Na}$ interpretação desse autor, na troca, as coisas trocadas não teriam valor por si sós, mas carregariam o espírito do doador, que permanece na coisa dada. 
dinheiro nele, ou porque foram construídos com certo material, de certa maneira ou por certa pessoa, mas também porque o proprietário investiu mais tempo nele, dedicou-se mais.

Edesmaria, no começo de 2008, saiu do acampamento Famílias Unidas para se instalar em outro acampamento na região de Araçatuba. Pouco antes de mudar, pôs à venda seu barraco. Edes, durante seu tempo no acampamento havia melhorado seu barraco aos poucos. Não só construiu mais um cômodo, mas melhorou o visual dele, plantando mais flores e também havia se dedicado à sua horta. De acordo com Ilma, vizinha de barraco de Edes, em conversa com outra vizinha mencionara que Edes havia conseguido vender o barraco por 100 reais; segundo ela, havia feito uma boa transação por causa da estrutura de madeira e os dois cômodos grandes, mas principalmente porque o barraco, "Edes cuidava bem, estava bem arrumadinho", inclusive, até, tinha deixado uma pequena hortinha. Essa dedicação, do ponto de vista de Ilma, justificava o valor do barraco e a boa venda.

Figura 2 - Acampamento Famílias Unidas: na frente do barraco de Edesmaria, o pequeno jardim que ela plantou; a parte branca (à esquerda) é o cômodo adicionado ao barraco

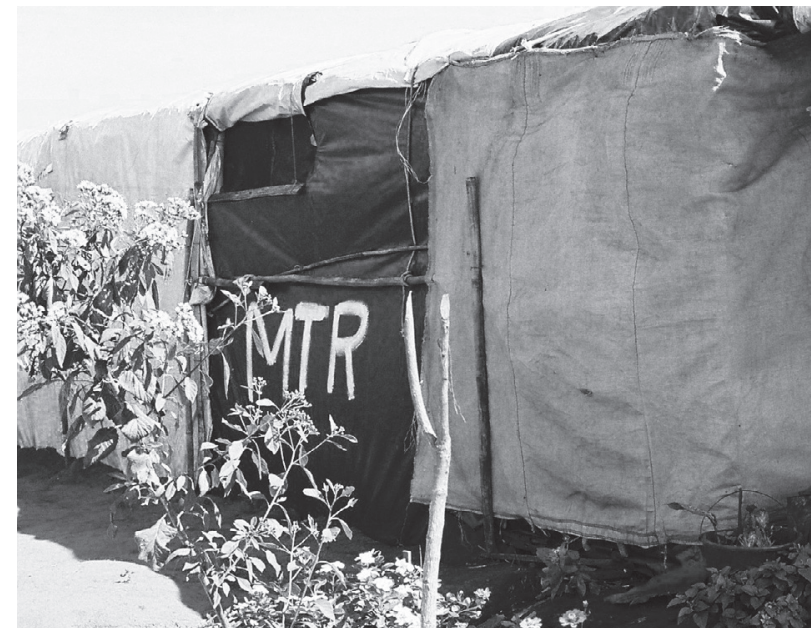

Foto: agosto de 2007 
Esses investimentos de tempo e dedicação nos barracos geralmente acontecem em acampamentos que têm muito tempo no mesmo lugar, como é o caso do Famílias Unidas, ou seja, depende dentre outras coisas das características do próprio acampamento onde é montado o barraco, em outras palavras, depende das formas de acampamento (Loera, 2010a e 2011). ${ }^{31}$

Como mencionei anteriormente, no TSM e no Dom Hélder, aquele que montava uma casa no seu barraco, com móveis, utensílios e muitos pertences, era considerado, na maioria das vezes, como inexperiente ou como novato no mundo das ocupações de terra e o tempo de acampamento nesses espaços estaria mais relacionado com um saber particular, com um know-how do mundo das ocupações. Essa concepção do tempo de acampamento também foi encontrada entre os acampados do Famílias Unidas, mas, nesse acampamento, tinha também outros significados. Diferentemente dos outros acampamentos, este último estava montado no mesmo local, na beira da estrada, fazia mais de seis anos, e o acampado que literalmente tinha montada uma casa no barraco, com móveis, jardim, sacada, garagem, era identificado como morador, mas, principalmente, como alguém que tinha tempo de acampamento ou tempo de barraco. ${ }^{32}$ Essa expressão é a mesma usada na contabilidade do

31 Como demonstrado por Loera (2010, 2011 e 2013), apesar de os acampamentos seguirem um modelo de organização determinado, uma forma acampamento (Sigaud, 2000) e determinados mecanismos de reprodução social, estariam constituídos por características próprias que conformariam variações desse modelo e que dependem do movimento que organiza o acampamento, das trajetórias sociais dos militantes e dirigentes envolvidos com a organização deles, da origem e das características socioeconômicas das famílias que se instalam debaixo da lona e das características da região onde os acampamentos são montados, pois isso também informa o perfil dos acampamentos constituídos por aqueles que moram e aqueles que não moram nos acampamentos. Essas variações ou características diferenciadas dos acampamentos constituiriam formas de acampamento, fórmula nativa que traduz essa diversidade da constituição social dos acampamentos.

32 Os acampados, ao longo de seis anos, fizeram duas ocupações dentro da Fazenda, levando consigo só poucos pertences e deixando os barracos montados na beira da estrada. 
tempo cronológico no acampamento, cujo controle, como vimos, se leva a cabo por meio do caderno de pontos e também é a mesma que se usa para fazer referência à experiência que se tem na arte de acampar, mas, como veremos no acampamento Famílias Unidas, parecia ter mais um significado: a dedicação ao barraco e ao acampamento.

Apoiada em algumas imagens, tentarei mostrar essa variante do tempo de barraco como percebido por alguns acampados.

\section{O barraco de Ilma e Donizete}

Figura 3 - Acampamento Famílias Unidas

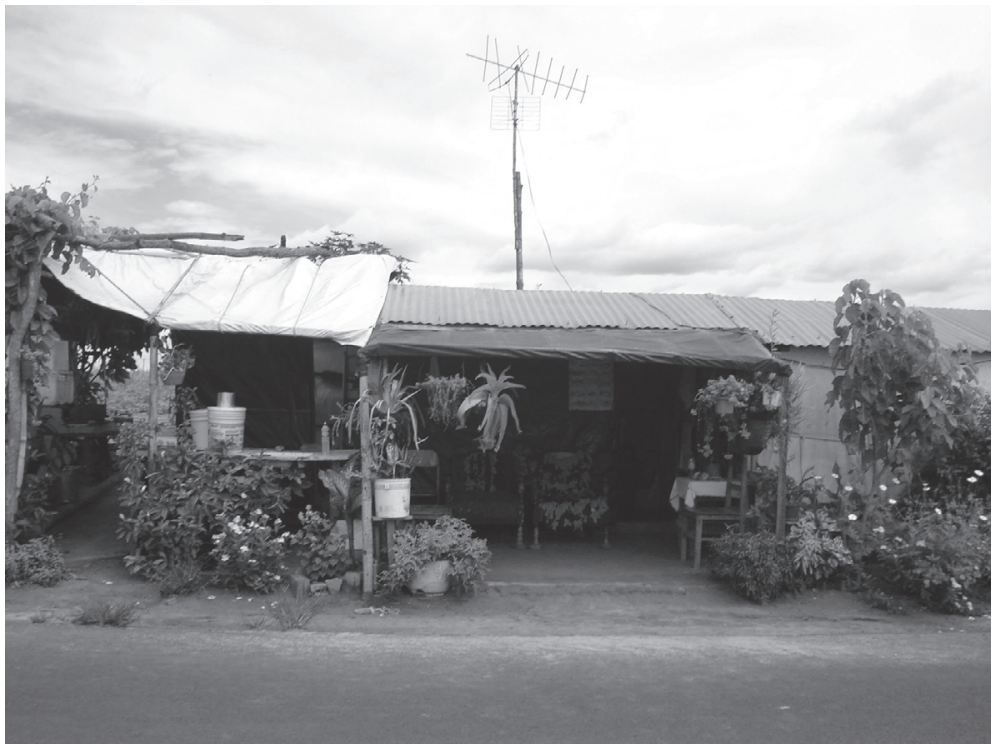

Foto: janeiro de 2009

Essa é a frente do barraco de Ilma e Donizete, ao lado das cadeiras que estão na varanda, é a entrada principal. Entrando logo à esquerda, a cozinha, e do lado direito um quarto com uma cama de casal e, no pé da cama, uma cama de solteiro, que era usada pelos netos do casal. Ao lado da cama uma penteadeira. Na parede, pen- 
duradas e bem arrumadas, variadas ferramentas de Donizete. Do lado esquerdo, coberto pelo teto de lona branco, estava a ducha e em frente a ela, a pia. O barraco, como vemos, estava coberto por plantas e flores que Ilma plantou ao longo de cinco anos. Atrás da primeira cadeira que vemos do lado esquerdo, está uma mesinha, onde Ilma costumava colocar um galão de água que ficava à disposição dos convidados. O teto do barraco foi coberto por lâmina, para tentar conter o calor. Esse barraco era dos poucos no acampamento que tinha uma antena de televisão instalada. Atrás do barraco Ilma guardava mudas de árvores frutíferas, dentre elas maçã, abacate, goiaba, maracujá e outras. Segundo Ilma, além de não ter mais lugar para plantar ao redor do barraco, as plantas aguardavam, em saquinhos, uma morada permanente. Alguns acampados mencionavam não plantar árvores frutíferas, já que viam o acampamento como um lugar de passagem e, para eles, essas árvores, pelo tempo que demoram a dar os frutos, representam permanência.

Figura 4 - Acampamento Famílias Unidas

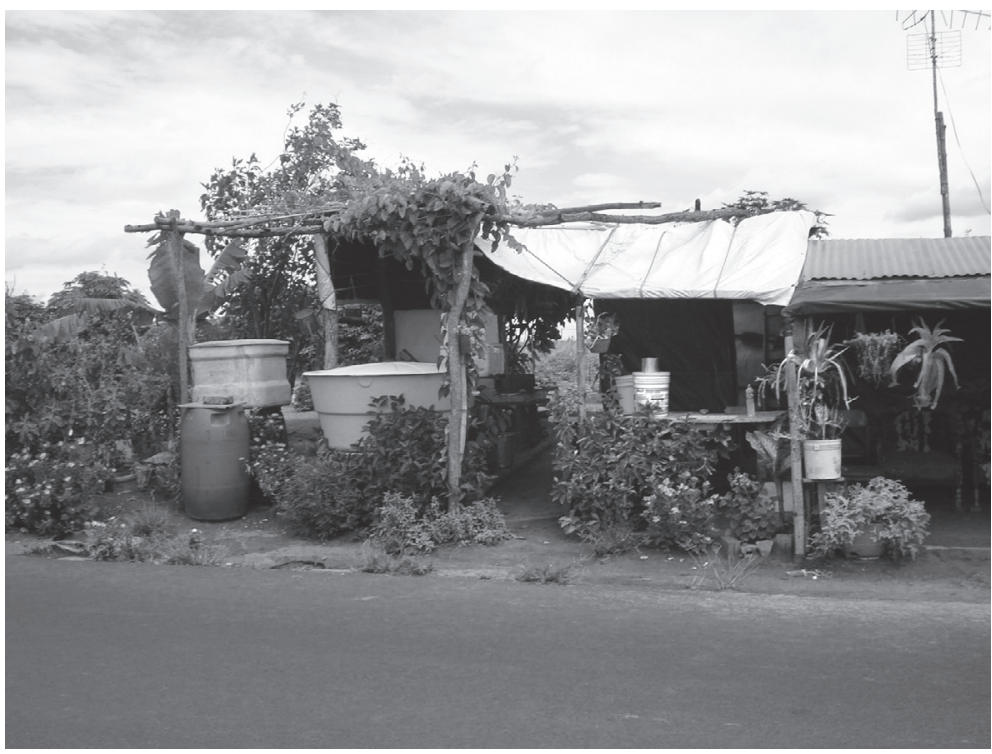

Foto: janeiro de 2009 
Fotos 5 e 6 - Acampamento Famílias Unidas
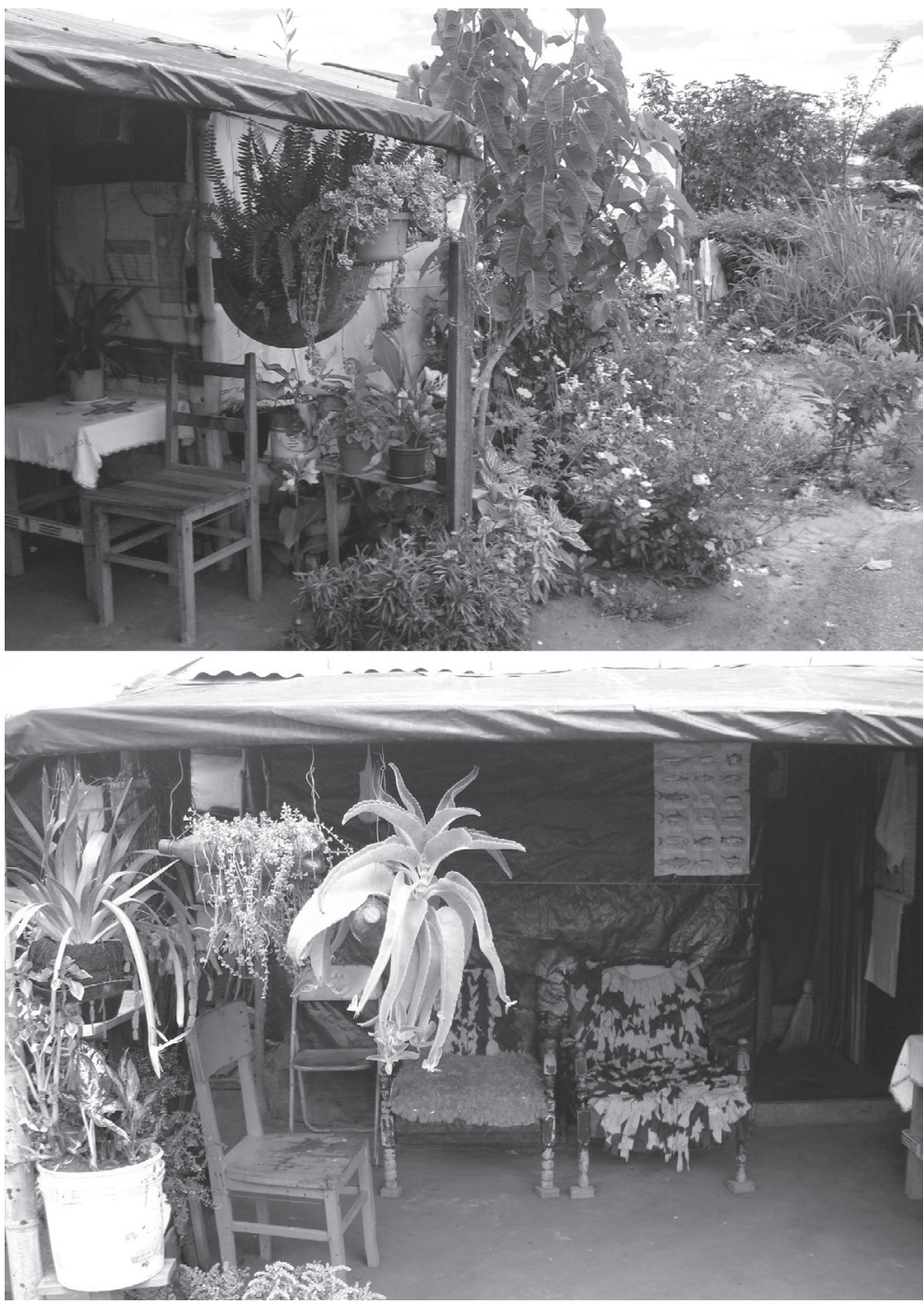

Foto: janeiro de 2009

No cantinho de Ilma e Donizete, como Ilma costumava referir-se a seu barraco, na Foto 4, totalmente do lado esquerdo, vemos uma estrutura de madeira coberta por uma trepadeira. Esse espaço 
costumava ser chamado de área, que, entre outras coisas, diferenciava o barraco de alguns moradores do restante dos acampados. Tal como a varanda, que vemos nas Fotos 5 e 6, a área era um lugar onde os donos do barraco costumavam sentar-se no final da tarde, para conversar ou receber as visitas. Segundo Donizete, era o lugar mais fresco do barraco. Do lado esquerdo na Foto 4, vê-se uma bananeira e outras árvores frutíferas no quintal, árvores que também foram plantadas por Ilma. Uma novidade encontrada nesse acampamento em específico foram as caixas de água instaladas nos barracos dos moradores ou dos que passavam mais tempo no acampamento. Outros acampados usavam só tonéis, que geralmente eram enchidos por pipas enviadas pela Prefeitura duas vezes por semana, como se vê na foto seguinte:

Figura 7 - Acampamento Famílias Unidas: um dia de pipa

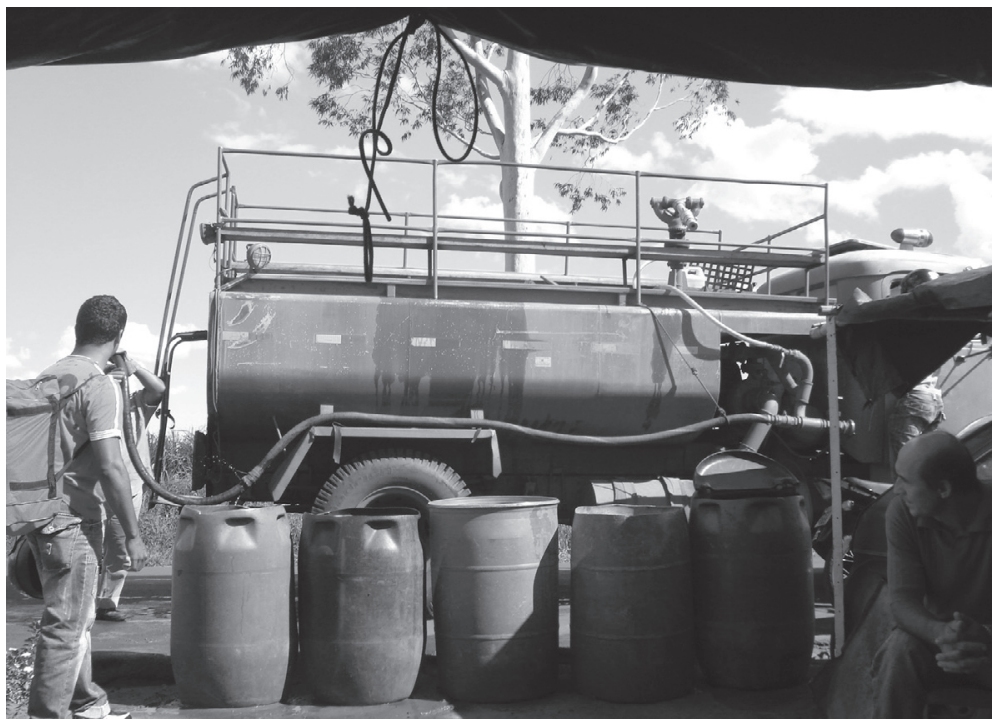

Foto: agosto de 2007

Os apoios ou os que cumprem regra de dois ou três dias normalmente têm um ou dois tonéis, que, de fato, muitas vezes acabavam ficando vazios, pois, muitas vezes, os dias de pipa não correspon- 
diam com os dias em que se cumpria regra, ou seja, com os dias que ficavam no acampamento. Esses apoios acabavam então pedindo água para moradores vizinhos de barraco ou outras vezes pediam para um vizinho de confiança para que a pipa enchesse seus tonéis.

Voltando ao barraco de Ilma e Donizete, vemos atrás da caixa de água, ainda na Foto 4, um isopor, onde se guardavam garrafas de água e outras bebidas, como refrigerantes, e também alimentos perecíveis. Nas Fotos 5 e 6, na varanda, sobressaem as plantinhas penduradas em vasos improvisados com pneu, garrafas, balde, latinhas etc. Esses utensílios, como as garrafas PET, de fato, adquirem bastante valor entre os moradores, mas principalmente entre os moradores dedicados a seu barraco. Ainda na varanda vemos um pôster colado na lona, que mostra diferentes tipos de peixes, que diz respeito a um dos hobbies preferidos de Donizete e, aliás, de muitos outros moradores da região: a pesca.

A estrutura do barraco, feita em maior parte de madeira, foi construída pelo próprio Donizete, ajudado pelo genro e outros vizinhos do acampamento. A estrutura de madeira, e não de bambu, também diferencia aquele que capricha no barraco daquele que não.

No quintal, na parte de trás do barraco, Ilma e Donizete tinham seus animais de criação e estimação, dentre eles três porcos, várias galinhas e um cachorro.

Figuras 8 e 9 - Acampamento Famílias Unidas: é comum novos e velhos acampados criarem animais de estimação que, na maioria das vezes, acabam acompanhando seus donos no percurso pelo mundo das ocupações de terra
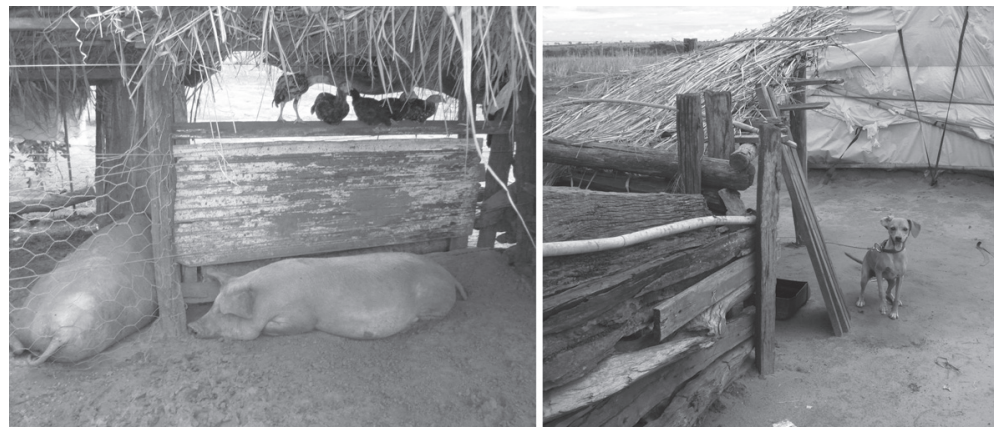

Foto: janeiro de 2009 
O casal comprou os porcos em 2007, quando Ilma decidiu morar no acampamento e começou a ficar inclusive até os finais de semana. O cachorro que ficava na casa deles em Andradina também se mudou para o acampamento. São esses animais os que, entre outras coisas, nas palavras de Ilma, "os prendiam ao acampamento".

Como mencionado anteriormente, Ilma e Donizete acampavam sob a bandeira do MTR, que, como já foi explicitado, para manter barraca sob essa bandeira, devia cumprir-se a regra de morar no acampamento. Donizete pegou uma vaga no acampamento, no final de 2005. Naquela época ele acampava sozinho em representação do genro, que, por trabalhar durante a semana, não podia ficar acampando. Ilma ficava na sua casa em Andradina e só de vez em quando ia para o acampamento. Donizete em 2009 contava com 53 anos e tinha parado de trabalhar com 47, depois de sofrer dois infartos num período de menos de um ano, o último deles aconteceu enquanto operava uma máquina dentro da empresa onde trabalhava em Andradina. Segundo ele, "a empresa o aposentou" e ele entrou em depressão. Tentou encontrar trabalho em vários lugares, preenchia todos os requisitos, mas, quando chegava ao exame médico, era barrado. Ele se questionava o seguinte: "como um cara novo que nem eu não ia fazer nada”. Segundo Ilma, "a situação era insuportável", ele "ficava aborrecido de ficar dentro de casa". Assim, a opção de ir para o acampamento mostrou-se como uma alternativa para estar ocupado, sentir-se útil, o acampamento deu um novo sentido à vida dele.

Depois do racha que já foi tratado anteriormente, entre apoios e moradores, Ilma passou a ficar mais tempo no acampamento, dois ou três dias por semana e, em 2007, ela passou a morar definitivamente no acampamento. ${ }^{33}$ Dessa maneira, Ilma e Donizete decidiram fazer um cadastro próprio. ${ }^{34}$ Ilma contava orgulhosa o

33 Ilma mantinha sua casa em Andradina ocupada por seu neto e a esposa dele.

34 Todos aqueles que montam um barraco devem fazer um cadastro com o coordenador do acampamento, que repassa a lista de acampados para o Incra. O cadastro é então uma maneira de formalizar a situação do acampado como candidato a um lote de terra. 
quanto ela se dedicava a seu barraco, o que incluía a varanda, a área, sua horta e seu quintal. Anteriormente, como relatado por Ilma, o acampamento não era para ela o lugar de morada ao qual devia dedicar muito tempo, era mais uma espécie de "sítio de final de semana". No entanto, a "dedicação" ao acampamento, e principalmente ao seu barraco, se tornou naquele momento uma das coisas que conferiam sentido à sua vida.

Figura 10 - Acampamento Famílias Unidas

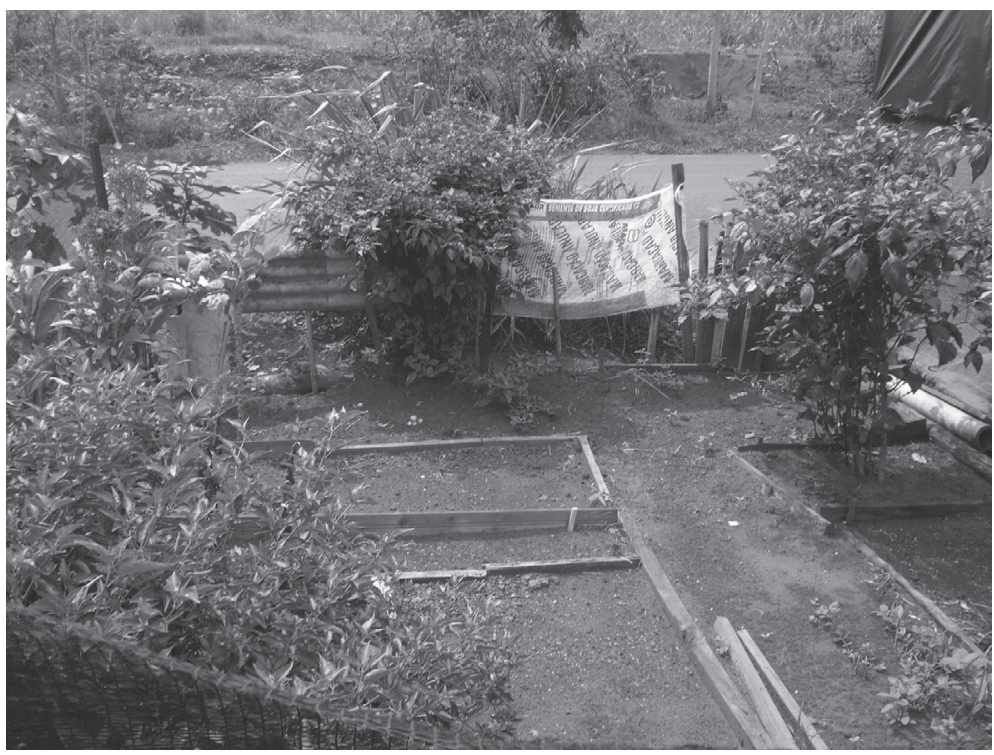

Foto: janeiro de 2009

Ilma plantou ao lado do seu barraco uma pequena horta de temperos, que ela usava diariamente para cozinhar, ou, muitas vezes, dava para suas vizinhas, quando precisavam. Conforme Loera:

$\mathrm{O}$ fato de ter e estar em uma barraca também dá direito de ter um espaço para plantar uma horta ou de ter criação [...]. Esses animais não servem de alimento para os acampados, mas, são objeto de troca ou são alimentados e cuidados esperando-se que no futuro, 
quando os acampados estiverem assentados, sirvam para reprodução. A barraca, portanto, indica quem é "o dono" da horta ou da criação e vice-versa. (2006, p.69)

Figuras 11 e 12 - Acampamento Famílias Unidas
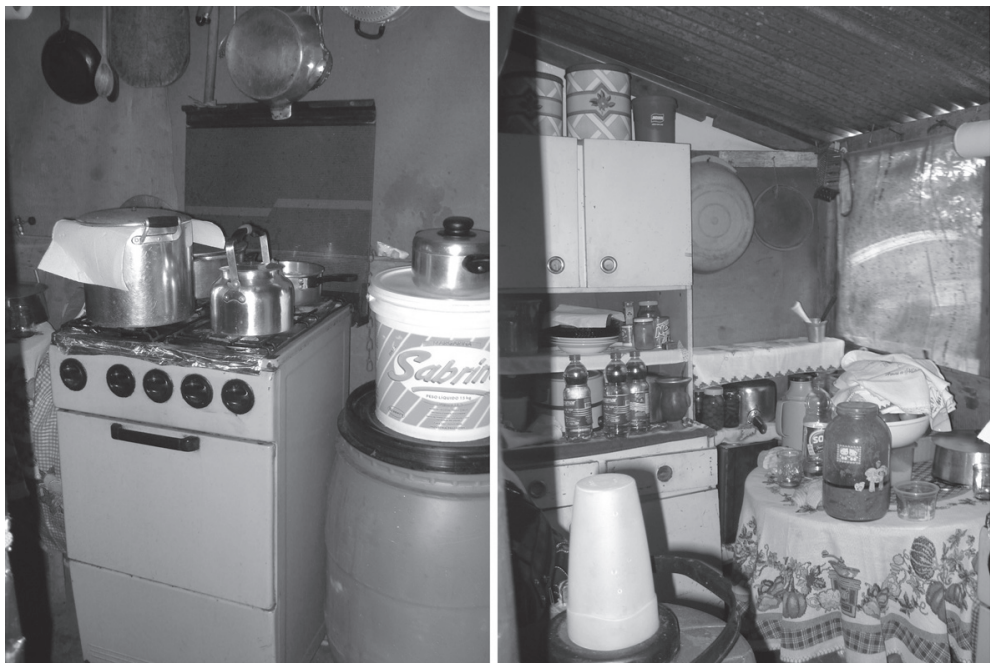

Foto: janeiro de 2009

As fotos anteriores (Figuras 11 e 12) mostram a cozinha onde Ilma preparava diariamente as refeições. Como vemos, está completamente equipada com um fogão, botijão de gás, galão de água, panelas, uma pequena mesinha e um pequeno armário, que por sinal servia também para estocar alimentos não perecíveis que recebiam na cesta básica ou compravam a cada quinze dias, quando geralmente iam fazer compra na cidade. A maioria dos móveis da cozinha também foram levados para o acampamento quando Ilma passou a morar nele. Já para Donizete, desde que Ilma virou moradora, ele pôde dedicar mais tempo às tarefas do acampamento e do movimento, principalmente prestando ajuda com o carro, quando Nino, o coordenador do MTR, precisava ir à cidade para conseguir ajuda ou para uma reunião com autoridades de governo e inclusive o levava até São Paulo quando precisava negociar apoios ou dar se- 
guimento no Incra à situação da fazenda. Em 2007, principalmente por causa desse trabalho que ele fazia para o acampamento e para o movimento, ele adicionou mais um espaço a seu barraco: uma garagem.

Figura 13 - Acampamento Famílias Unidas

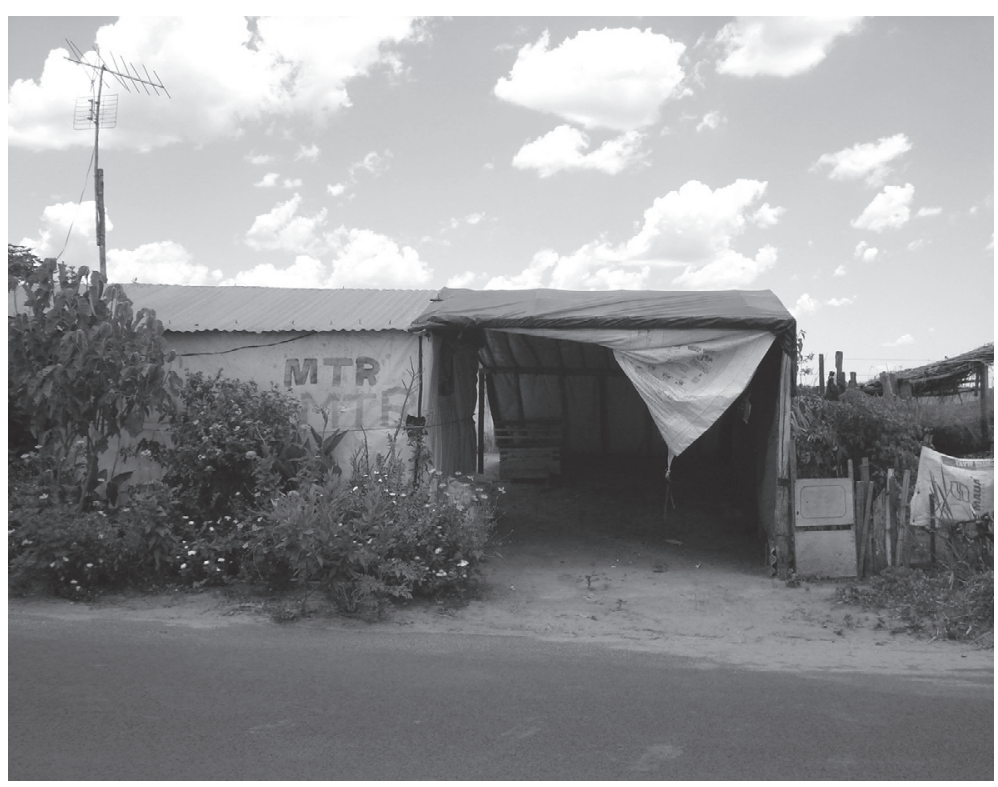

Foto: janeiro de 2009

\section{O barraco de dona Leo}

Como mencionei anteriormente, as vidas se narram através do barraco e é tema de conversas cotidianas entre acampados, personagens de aventuras e dificuldades passadas nos acampamentos e marco de entrada no mundo das ocupações, e também, como vimos no caso do barraco de Ilma e Donizete, pode ser símbolo de orgulho e de dedicação de alguns acampados. E essa dedicação é também uma forma de legitimar o tempo de acampamento. 
Figura 14 - Acampamento Famílias Unidas

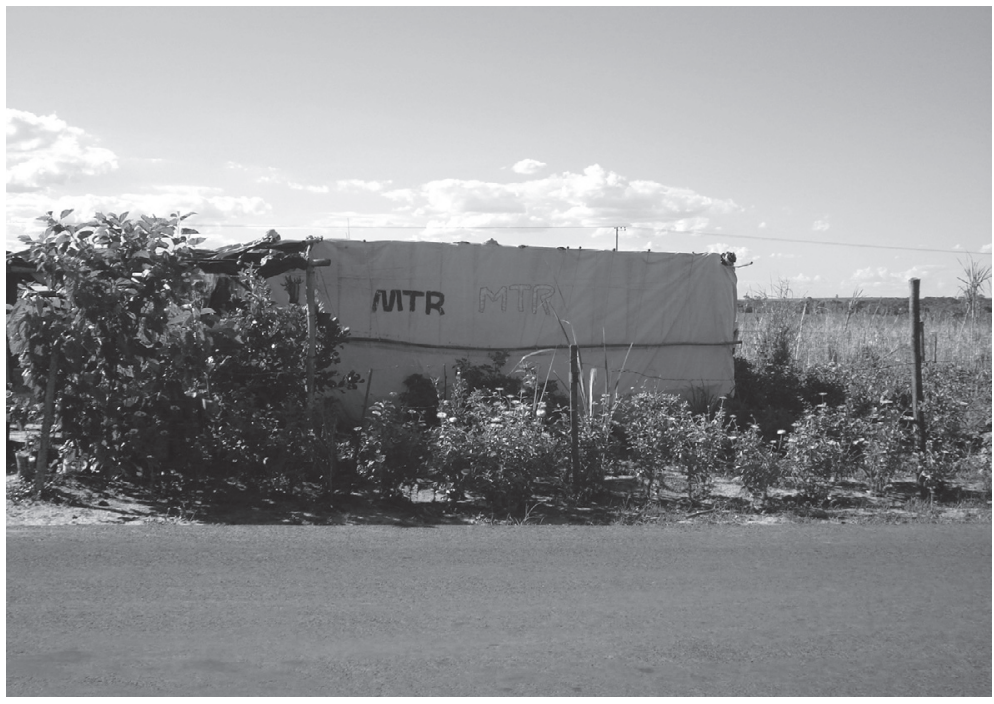

Foto: janeiro de 2009

Dona Leo ou madame, como era carinhosamente chamada pelo seu marido, estava há menos tempo no acampamento do que outros moradores, no entanto, era percebida no acampamento como alguém com tempo de barraco, como alguém dedicada.

Dona Leo chegou ao acampamento no final de 2007. Ela havia aguardado mais de três meses em outro acampamento da região, na Fazenda Brinco de Ouro, para uma vaga no acampamento Famílias Unidas. Seu filho caçula já acampava fazia vários meses sob a bandeira do MTR e foi ele quem pediu para Nino, o coordenador, uma vaga para sua mãe morar.

Apesar de ter sido o filho quem lhe conseguiu uma vaga no acampamento, foi ela que o animou a acampar. Segundo ela, seu filho ficou sem emprego e não conseguia pagar as contas e foi quando um conhecido que já estava acampado lhe informou da possibilidade de acampar. Como assinalado por Sigaud (2000), nem todos os trabalhadores se dirigem às terras ocupadas em busca de um pedaço de chão, muitos o fazem como uma saída a curto prazo, 
como uma saída para uma situação de precariedade. No entanto, "quando um indivíduo passa a fazer parte de uma ocupação [e de um acampamento] crê e aposta nas possibilidades da lona preta" (Sigaud, 2005, p.266). No entanto, a "aposta" só se torna possível graças às relações preexistentes entre organizações de trabalhadores rurais, assentados, acampados e acampados potenciais; é essa trama de relações que permite não só uma articulação de ocupações subsequentes, mas também a circulação da crença na ocupação e no acampamento como mais uma possibilidade dentro do universo das opções.

Uma das coisas que levaram dona Leo a se instalar debaixo da lona foi o desejo de ficar perto de seu filho e de seus netos que acampavam junto com ele, mas também foi uma situação econômica e emocional difícil. Seu marido trabalhou muitos anos como jornalista num jornal de Andradina, fazendo a matéria de esportes, e ela, orgulhosa, me relatava que até pouco tempo atrás ela usava "sapatinho alto e vestidinho bom" e participava de "ceias de luxo ao lado de prefeito, vereador, dos políticos”. Depois que seu marido, por causa de um derrame, não conseguiu mais trabalhar, dona Leo decidiu tentar sorte no acampamento, a lona preta apresentou-se como uma oportunidade num momento difícil da sua vida, de ter um futuro melhor. Seu marido não gostou da ideia de ir com os sem-terra, mas acabou se juntando a ela depois de alguns meses.

Dona Leo, com o consentimento de Nino, coordenador do MTR, instalou seu barraco numa área grande. Nino lhe concedeu um espaço equivalente a dois barracos. $\mathrm{Na}$ foto anterior (Foto 14) vê-se o barraco e na foto seguinte (Foto 15) vê-se o resto do espaço ocupado pelo barraco da dona Leo. Completamente do lado esquerdo, na mesma foto, está o banheiro. Do lado está o curral e dentro dele o galinheiro e o chiqueiro dos porcos. ${ }^{35}$ Dona Leo tinha três porcos, várias galinhas, três cachorros e um papagaio. Mas desses animais todos, dona Leo tinha dois preferidos: Torresmo, um

35 Curral é o termo usado para falar do espaço destinado aos animais em geral e que abriga porcos, galinhas, cabras etc. 
dos porcos, e sua cachorra de nome Duquesa, que dormia também debaixo da lona, num pequeno barraco feito para ela, que vemos do lado esquerdo, coberto por lona branca.

Figura 15 - Acampamento Famílias Unidas

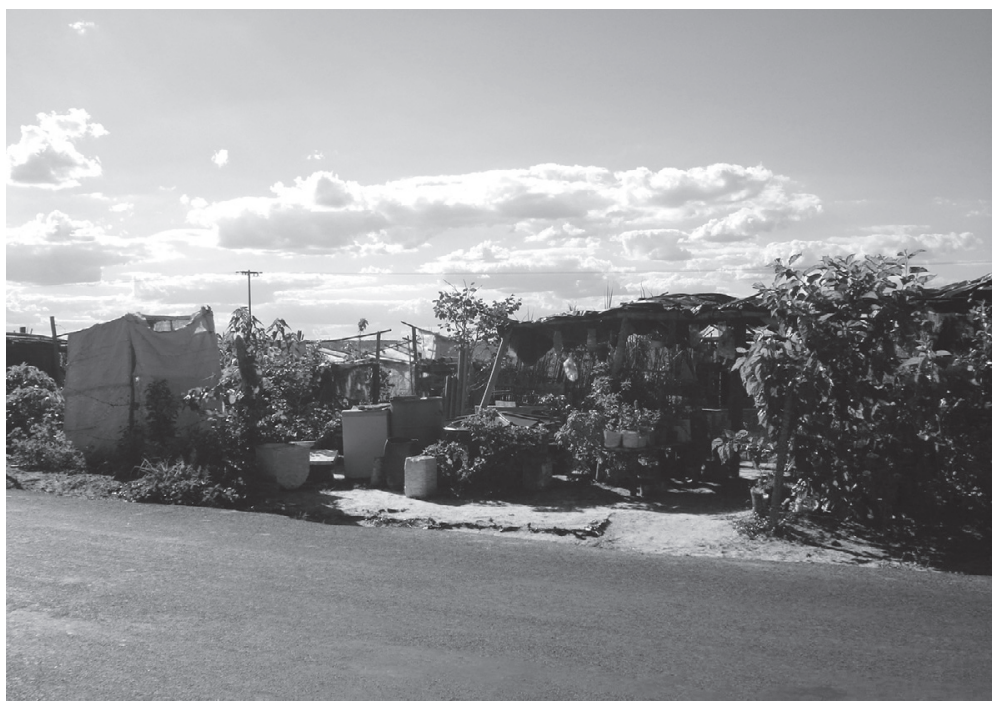

Foto: janeiro de 2009

Entre o barraco e o curral, está o que ela chamava de área. $\mathrm{Na}$ área tem uma mesa, um banco e o que resta de uma estrutura de bambu, que antes era o quartinho dos netos de dona Leo, os quais durante um tempo ficaram com ela. Depois, quando os netos foram embora, esse espaço começou a servir para guardar sementes, latas, vidros e as tão prezadas garrafas PET.

Devo mencionar que o barraco para os moradores não corresponde somente ao barraco em si, mas a todos os outros espaços ao redor dele, que são construídos e usados por esses moradores: a área, a varanda, o quintal, o curral, o galinheiro, a horta.

O barraco se estende então a todos esses espaços, que, ao longo do tempo, vão se tornando um só, reproduzindo verdadeiros pequenos "sítios" dentro do acampamento. 
Na área, como se vê na foto abaixo (Figura16), há pequenas árvores frutíferas: mamoeiro, cajueiro, goiabeira e acerola. Nos fundos, um tanque e um varal.

Figura 16 - Acampamento Famílias Unidas

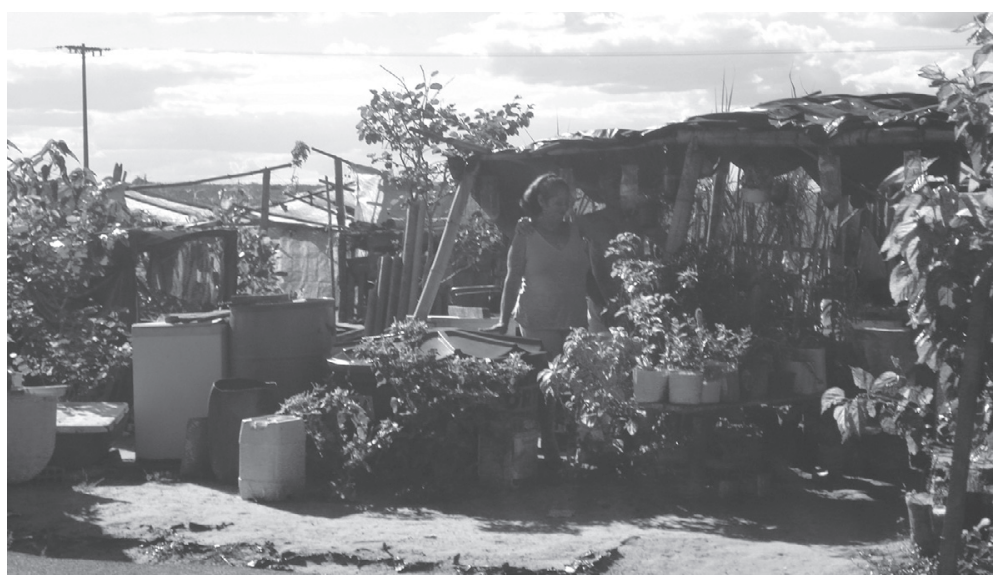

Foto: janeiro de 2009

Dona Leo era uma das que tinham mais variedade de plantas e temperos e também mudas de café, maçã, laranja e vários tipos de cactos que ela mantinha em pequenos potinhos, esperando poder replantar quando entrasse na terra. ${ }^{36}$ Dona Leo juntava todas as sementes que ia encontrando por aí e logo as plantava em pequenos potes ou garrafas. Quando a conheci, no barraco do Nino, fez questão de me levar até seu barraco para me mostrar sua pequena plantinha de café, fruto de uma semente que trouxe da cidade, quando foi para o acampamento dois anos antes. Para ela, a própria plantinha era uma prova do seu tempo de acampamento. Dona Léo também gostava de mostrar com orgulho a docilidade dos seus porquinhos, para ela de tão dóceis até "pareciam cachorros". Segundo ela "para um animal desses, acostumar com a pessoa, demora tempo".

36 Essa expressão faz referência ao momento em que acampados conseguem entrar na sua terra, já como assentados. 
Figura 17 - Acampamento Famílias Unidas: as mudas de dona Leo

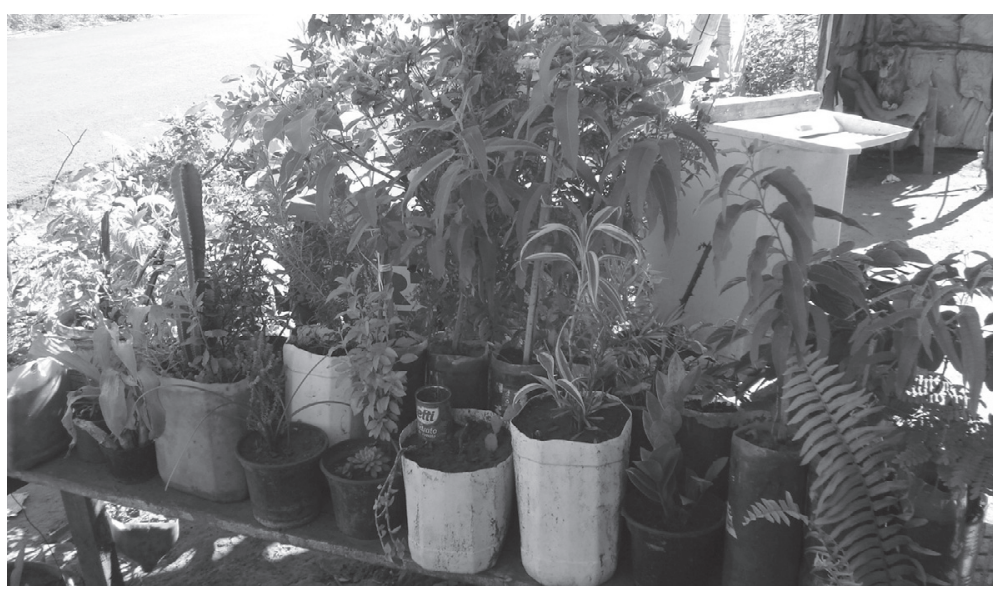

Foto: janeiro de 2009

Penduradas no teto da área, vemos garrafas PET, que serviam como regadores. Essas garrafas eram cheias de água e era feito um pequeno buraco na tampa para a água pingar aos poucos nas plantinhas. Ao fundo, vê-se o barraco da Duquesa e ela deitada em cima do seu colchão. Na foto abaixo, dona Leo mostra orgulhosa suas mudas.

Figura 18 - Acampamento Famílias Unidas: dona Leo

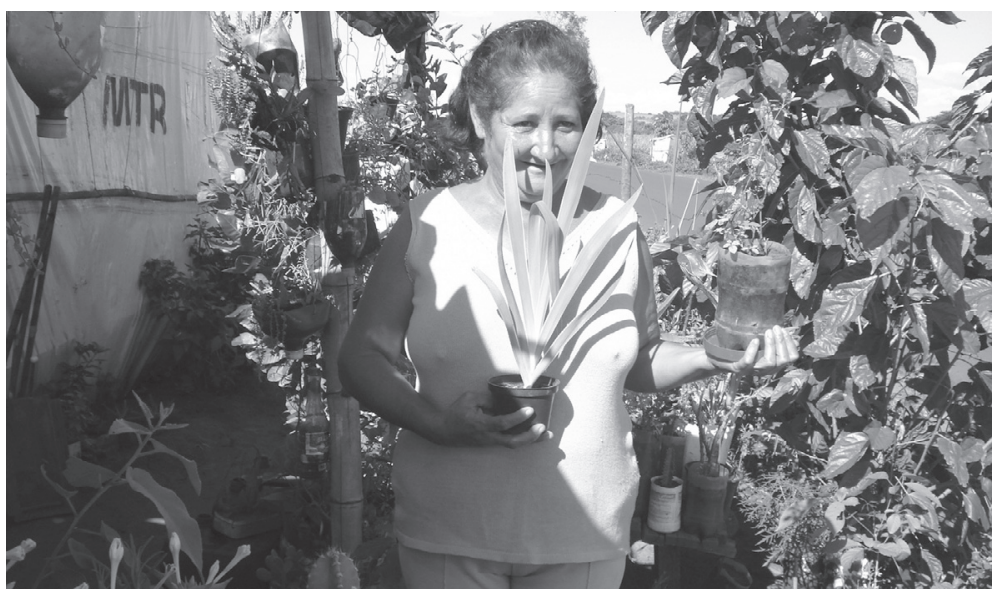

Foto: janeiro de 2009 
O barraco dela tinha dois cômodos separados por duas pequenas estantes e uma cortina de tecido (Figura 19). Num dos cômodos tinha uma cama de casal, do lado da cama, empilhadas, várias caixas de papelão cheias de roupa e outros pertences, ao lado delas, uma pequena janela. No outro cômodo estava instalada a cozinha com um armário grande, que ocupava quase todo o espaço de um lado inteiro do barraco. Vê-se também uma janela coberta por um mosquiteiro (Figura 20).

Figura 19 - Acampamento Famílias Unidas: estante que separa os dois cômodos do barraco

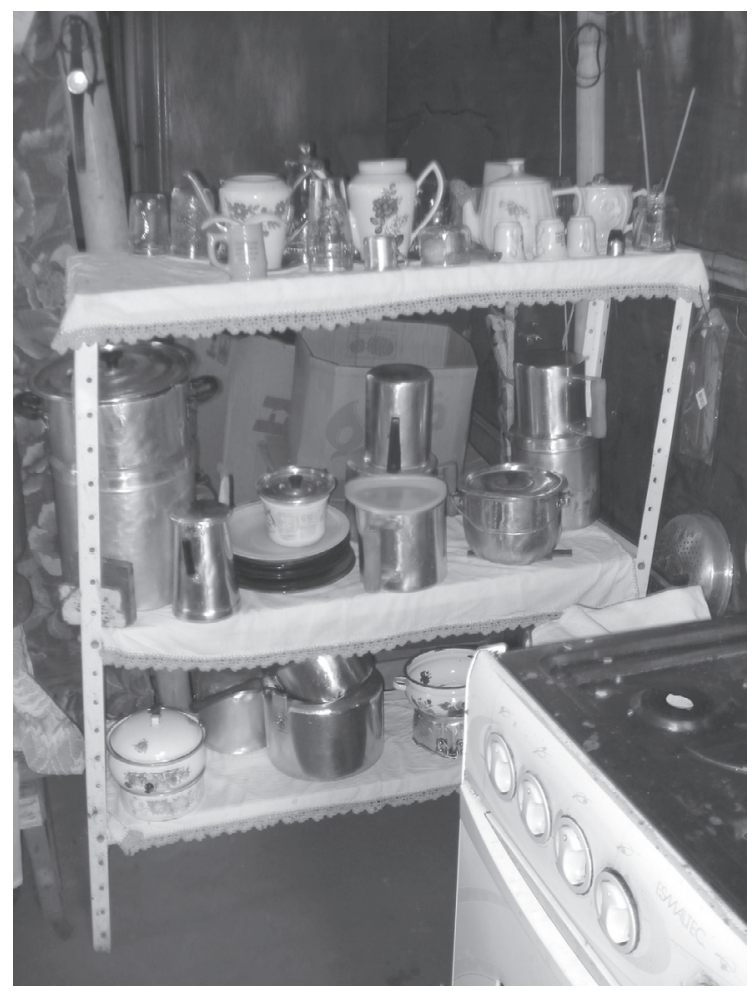

Foto: janeiro de 2009 
Figura 20 - Acampamento Famílias Unidas: cozinha de dona Leo

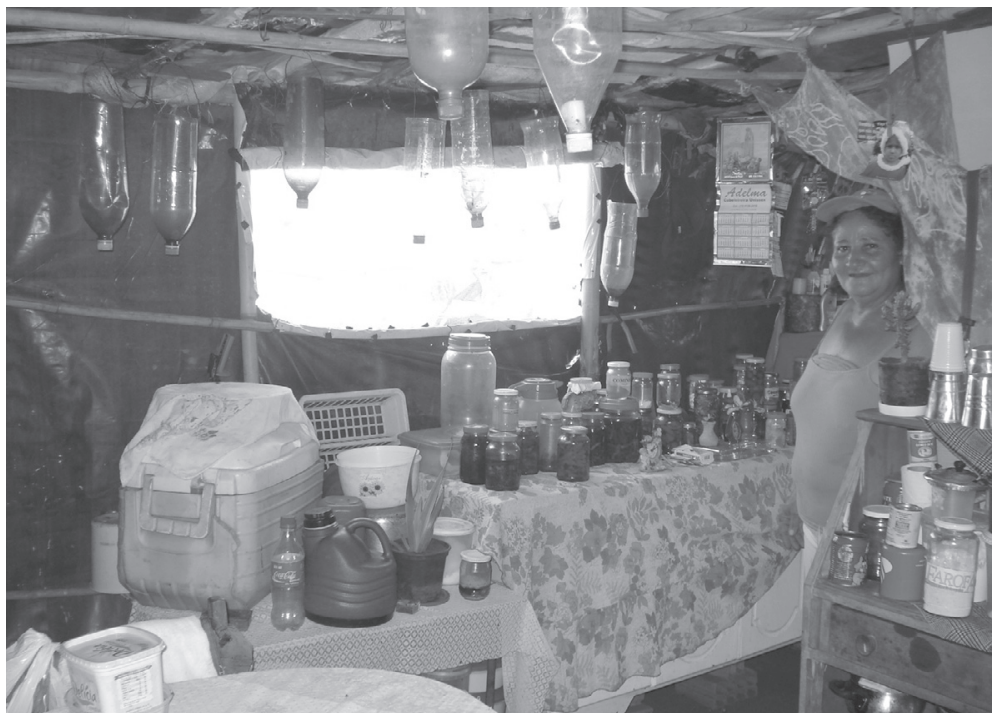

Foto: janeiro de 2009

Dona Leo, como se vê na foto anterior, tal como Ilma e outros moradores, usava um isopor para guardar água e alimentos perecíveis. As garrafas penduradas no teto do barraco serviam para armazenar a água que pingava da lona quando chovia, que depois era aproveitada para regar suas plantas. $\mathrm{O}$ marido de dona Leo empilhava garrafas vazias no quintal, que ia recolhendo por onde passava. Numa das últimas visitas, ele chegou da cidade com um saco de garrafas PET na mão, que tinha recolhido das ruas. Daí a importância que tinham as garrafas e recipientes tornando-se bens valorizados entre os moradores do acampamento. Dona Leo também tinha orgulho de mostrar todas as conservas de doces e de diferentes pimentas que ela fazia com os frutos colhidos na sua horta e no seu quintal (ver em cima da mesa na Figura 20). De alguma forma eram também prova da sua dedicação ao barraco.

Segundo dona Leo, ela deixou a casa fechada em Andradina e fez praticamente uma mudança para o acampamento, levando con- 
sigo muitos dos seus pertences. Para ela, o acampamento virou seu lugar, e seu barraco é uma prova visível do seu empenho, e é aquilo, que de alguma forma, legitima seu tempo de acampamento.

No acampamento Famílias Unidas, principalmente entre os moradores, era comum que não somente falassem sobre seus barracos e seu empenho e investimento neles, mas comparassem seu tempo de barraco ou dedicação com o dos seus vizinhos, especialmente com alguns moradores de final de semana ou apoios, que, na percepção de alguns moradores, eram aproveitadores, pois, apesar de não ficarem debaixo da lona e terem seus barracos largados, iriam ser contemplados como iguais na hora da repartição de lotes de terra.

Vejamos graficamente essa disputa através de algumas imagens de barracos de moradores e de apoios do acampamento Famílias Unidas.

\section{Barracos de moradores}

Figura 21 - Acampamento Famílias Unidas: a trepadeira tomou conta da área do barraco de um dos moradores do acampamento

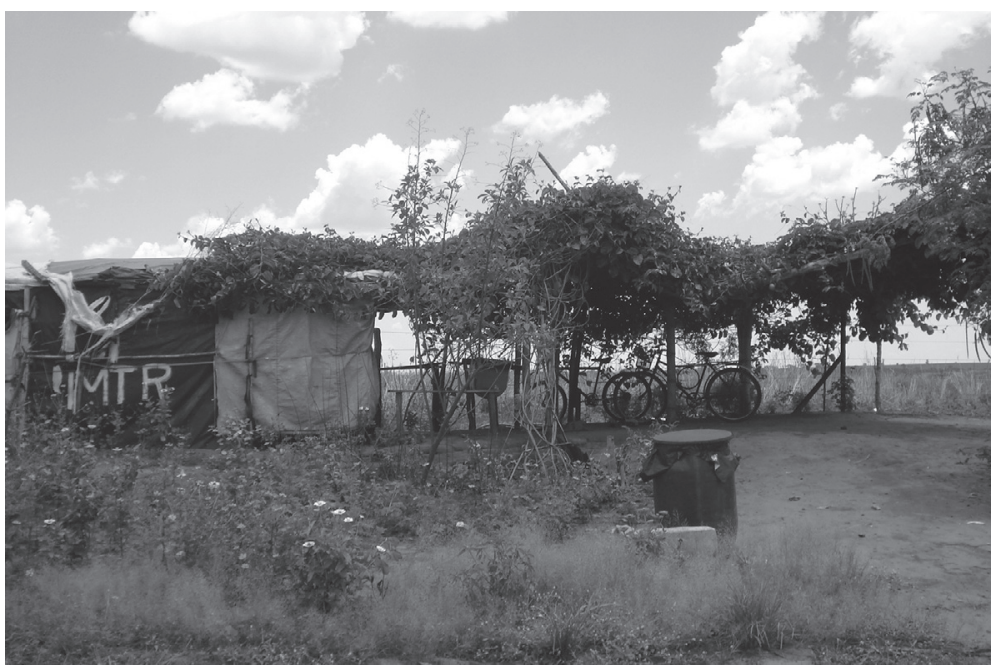

Foto: janeiro de 2009 
Figura 22 - Acampamento Famílias Unidas: o barraco original de uma das moradoras mais antigas foi coberto por uma "lona natural" de pé de maracujá (o barraco de lona branca à direita da foto é um cômodo adicionado)

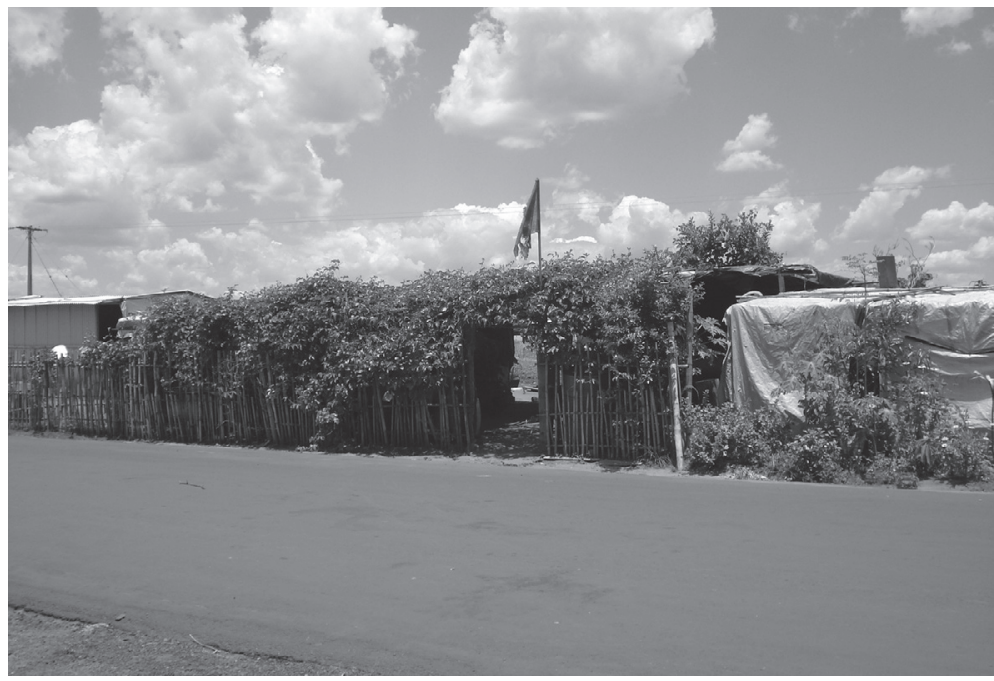

Foto: janeiro de 2009

Figuras 23 e 24 - Acampamento Famílias Unidas: plantio de abóbora e de mandioca num dos barracos de moradores.
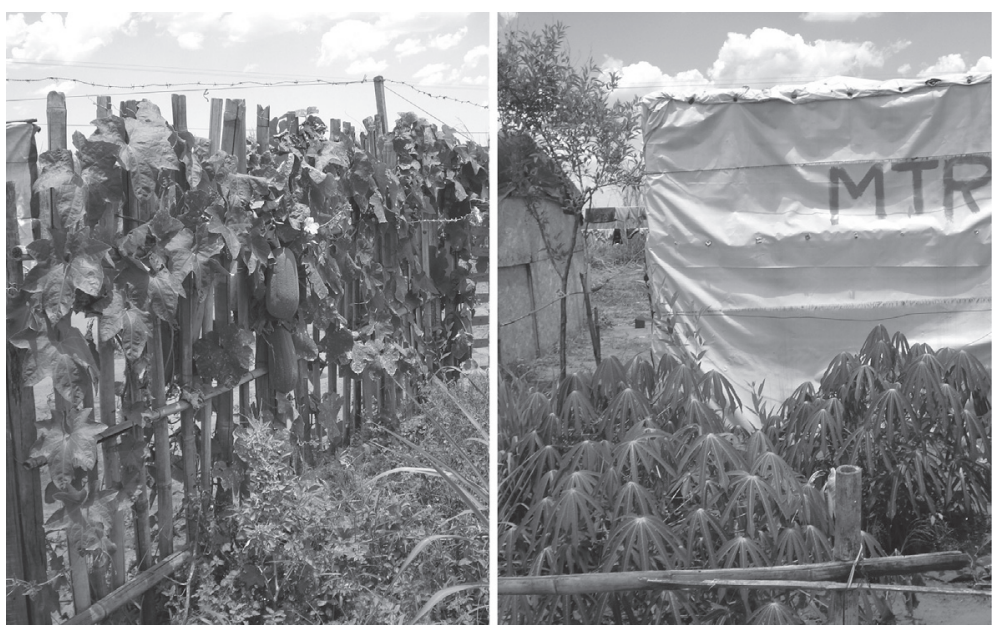

Foto: janeiro de 2009 
Figura 25 - Acampamento Famílias Unidas

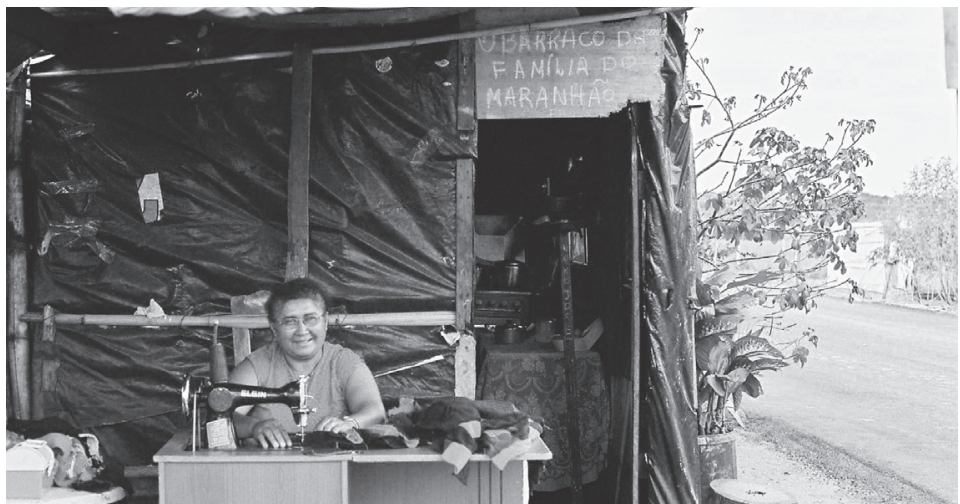

Foto: agosto de 2007

Rose tinha um ateliê de costura no seu barraco. Fazia roupa, colchas e principalmente cortinas e tapetes sob encomenda ou avulsos, que vendia para outros acampados ou para clientes da cidade, que já conheciam seu trabalho e que iam para o acampamento exclusivamente para comprar os produtos.

\section{Barracos de apoios}

Figura 26 - Acampamento Famílias Unidas

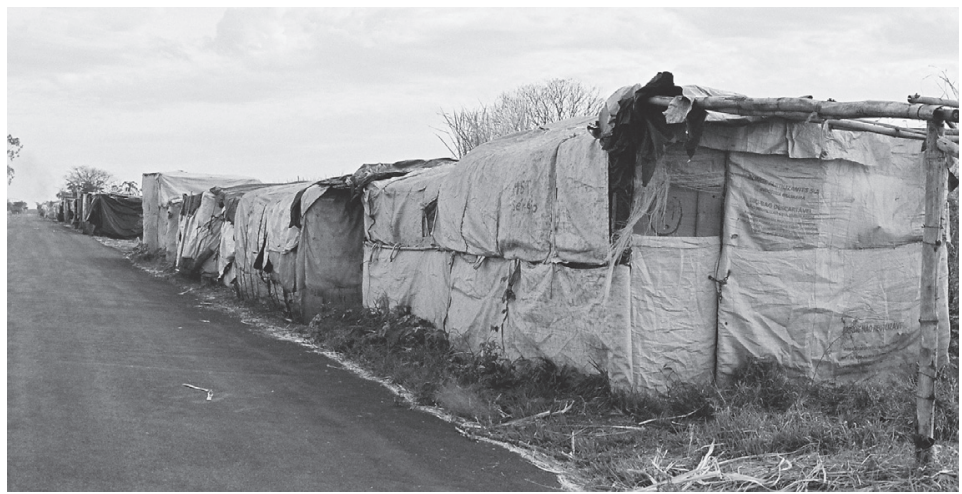

Foto: agosto de 2007 
Alguns barracos de apoios ou que cumprem regra - ligados entre si por laços de parentesco - ficavam enfileirados ao longo da estrada, uns colados aos outros. A maioria dos barracos ficavam fechados com cadeado (Figura 26), quando não era dia de cumprir regra.

Figura 27 - Acampamento Famílias Unidas

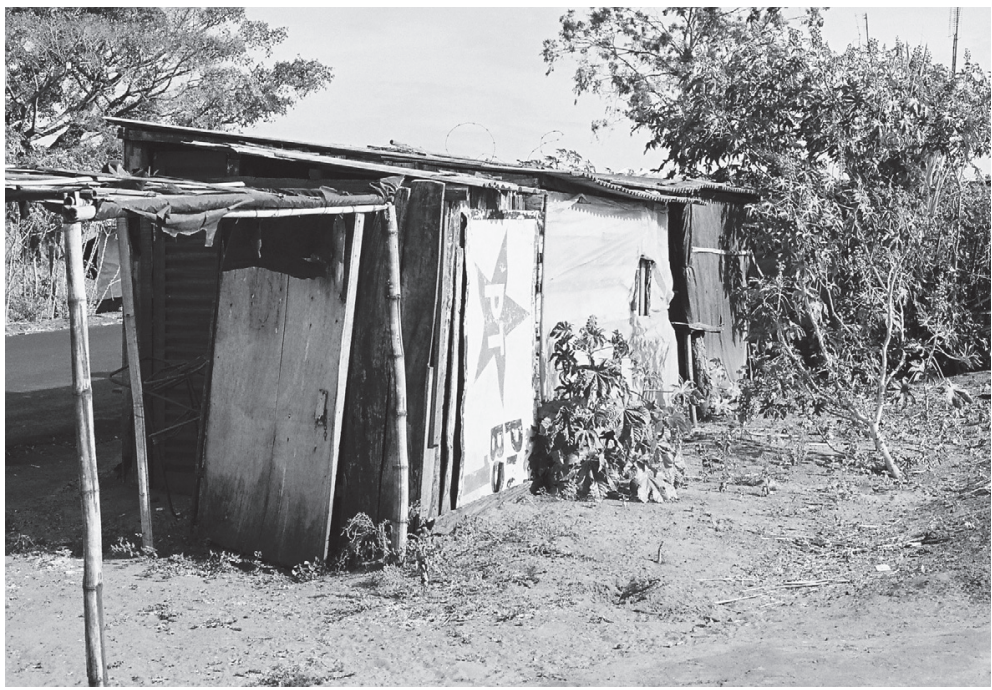

Foto: agosto de 2007

Geralmente nos barracos dos apoios, diferentemente dos barracos dos moradores, não havia horta, varanda, quintal ou área, e o espaço do barraco limitava-se ao barraco.

Como se vê nas duas fotos seguintes (Figuras 28 e 29), nos barracos dos apoios ou moradores de final de semana devia ser marcado a sigla do movimento com o qual se acampava e o nome do dono do barraco. 
Figura 28 - Acampamento Famílias Unidas

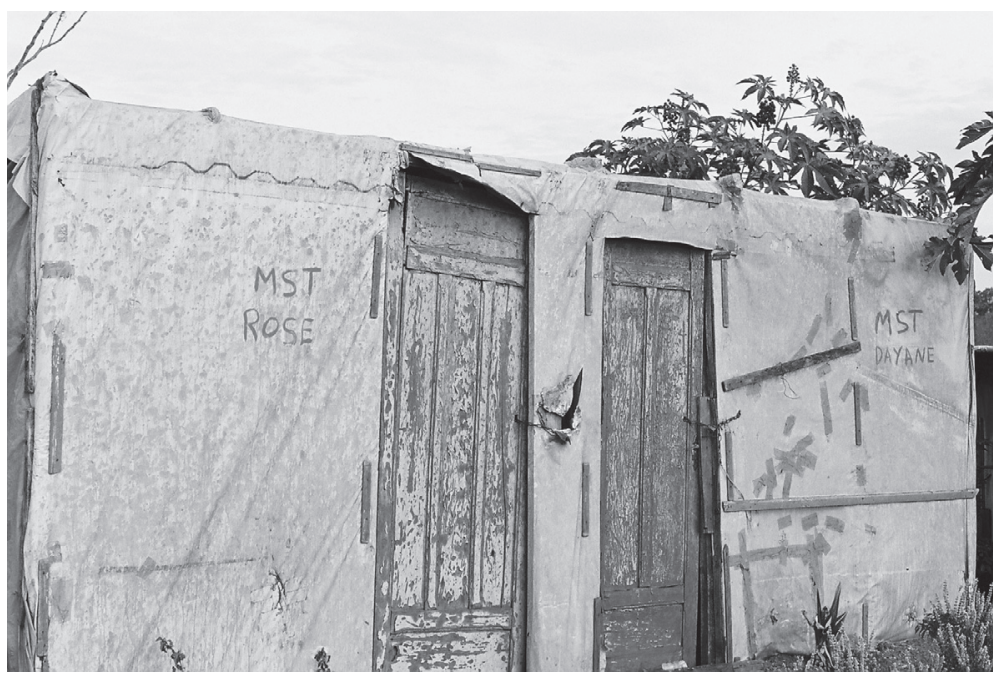

Foto: agosto de 2007

Figura 29 - Acampamento Famílias Unidas

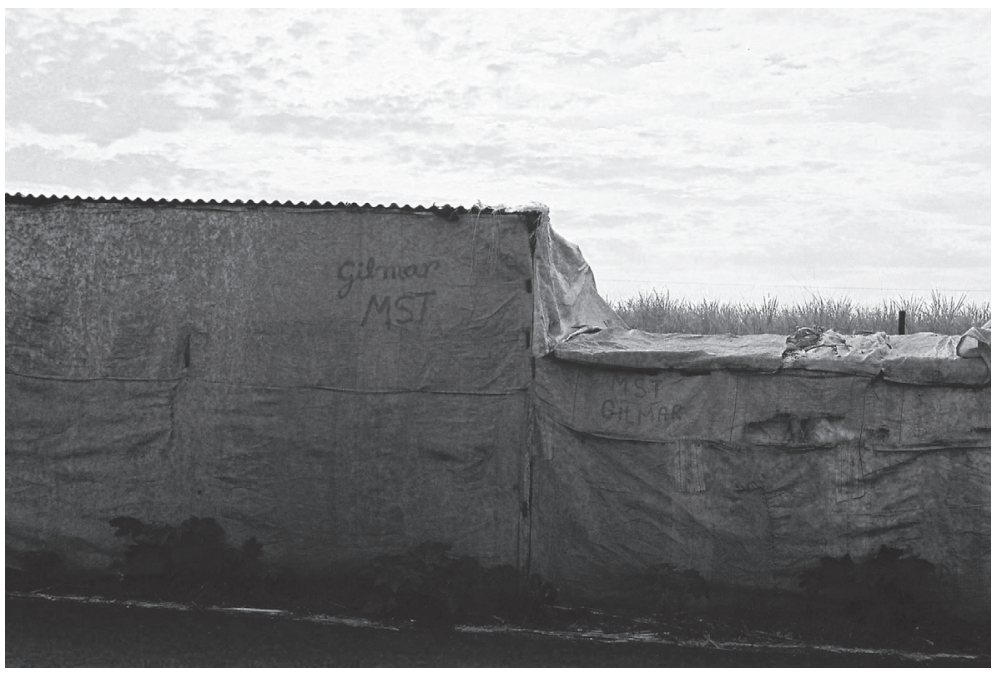

Foto: agosto de 2007 


\section{Donos do acampamento}

O bom observador terá notado que na maioria das fotos, nos barracos dos moradores, aparece a sigla MTR, e nos barracos dos apoios aparece a sigla MST. Como foi mencionado anteriormente, Nino, coordenador do MTR, colocou a regra de morar como requisito para manter barraco sob a bandeira do "seu" movimento. Já para o Biro, coordenador dos acampados pelo MST, não era obrigatório morar no acampamento, mas era obrigação, sim, passar um tempo no acampamento, cumprindo regra de dois, três, ou quatro dias, e principalmente participar de jornadas (marchas, ocupações, passeatas etc.).

Assim, o cumprimento das obrigações, morar e cumprir regra de $\mathrm{x}$ dias se dava dependendo da vaga que foi negociada, de morador ou de apoio, e dependendo com quem foi negociada, com Nino ou com Biro. Ou em palavras nativas, dependendo do dono do acampamento.

Como já foi tratado por outros autores (Sigaud, 2004; Rosa, 2011), as ocupações e os acampamentos e suas bandeiras constituem-se enquanto afirmações simbólicas, como uma maneira de dizer a qual movimento "pertencem".

Nos termos de Sigaud:

As ocupações e os acampamentos constituem uma linguagem simbólica, um modo de fazer afirmações por meio de atos, e um ato fundador de pretensões à legitimidade. Ao promover uma ocupação e um acampamento o movimento diz ao Incra que deseja a desapropriação das terras, ao proprietário que quer suas terras e aos outros movimentos que aquela ocupação tem um dono. (2004, p.19)

Os dados recolhidos em campo sugerem, no entanto, que não somente ao colocarem uma bandeira se demonstra que o acampamento pertence a determinado movimento, mas também os acampados se percebem como os donos dos seus barracos, e mais, também concebem os acampamentos como personificados, como tendo donos e se faz referência a eles pelo nome do dirigente, militante ou coordenador do acampamento. Edesmaria, por exemplo, quando mudou de acampamento no município de Araçatuba, mencionava que estava acampando em "um acampamento de Zé Rainha”. Ou seja, não 
é só o movimento, como entidade coletiva, que é visto como o dono dos acampamentos, mas são principalmente os indivíduos de carne e osso que organizam os acampamentos. Inclusive, é comum que os acampados façam referência aos acampamentos como do Nino (MTR), do Biro (MST), do Neguinho (Sintraf), do Cláudio (Sintraf, CUT) etc. Nos relatos de acampados da região sobre suas "entradas" aos acampamentos, faz-se referência a terem conseguido uma vaga do Nino, do Biro, do Luiz, do Rainha e assim por diante.

Por outro lado, assim como há um investimento por parte de alguns acampados para com seu barraco, há um investimento por parte dos donos do acampamento para com seu acampamento, impondo regras próprias, delegando tarefas, formas de gerenciar o acampamento, decidindo, por exemplo, onde são instalados os barracos, dando vagas etc. E é precisamente esse investimento, essas formas diferenciadas de administrar os acampamentos o que indicaria quem é o dono do acampamento. Em outras palavras, os acampados sabem quem é o dono, dependendo também da forma do acampamento (Loera, 2010a).

De fato, entre os interessados em se instalar debaixo da lona, um dos critérios de escolha pode ser o dono do acampamento e qual a forma de acampamento, isto é, como o acampamento é operacionalizado e organizado, por quem e quais são as regras para manter barraco. Existiriam, portanto, por parte dos interessados em participar de um acampamento, preferências por determinados acampamentos. No caso do acampamento Famílias Unidas, por exemplo, a escolha, como já foi mencionado anteriormente, passava, para alguns acampados potenciais, pelo movimento que organiza o acampamento, mas, para outros, ter a opção de cumprir regra de $\mathrm{x}$ dias ou de morar podia ser também o motivo da escolha, dependendo das necessidades daquele que pretendia montar barraco no acampamento.

Na região, ser o dono de um acampamento pode representar uma forma de capital social e simbólico: aquisição de nome, reconhecimento, prestígio e relações.

Rosa (2011) menciona, para o caso da Zona da Mata Sul Pernambucana, que, para algumas pessoas, ter um movimento próprio pode significar possuir uma posição social privilegiada em sua região, e o 
desejo de significação social encontra recepção naqueles que os rodeiam. Ainda, como assinalado por esse autor (2009b), as lideranças dos movimentos na região por ele estudada, na Zona da Mata de Pernambuco, conseguem ter um acesso a certas pessoas (representantes do Incra, autoridades e políticos locais), acesso que dificilmente conseguiriam se não fossem representando um movimento.

Na região oeste de São Paulo, não parece ser muito diferente. No caso específico do Nino, por exemplo, como coordenador de acampamento, ele não só era percebido por outros acampados como o dono de um acampamento, ou pelo menos de uma parte dele, mas era também o fundador e único dono de um movimento, o MTR.

Nino, foi militante do MST na região e chegou a ser assentado, mas nunca ocupou um posto de coordenação estadual ou nacional no MST, e foi somente a partir do momento em que se tornou coordenador do MTR do acampamento Famílias Unidas que começou a frequentar, enquanto representante dos acampados, espaços institucionais, como prefeituras, e ser recebido por autoridades locais e do Incra, inclusive de São Paulo. Ele, por exemplo, me relatou um episódio em que Edesmaria, sem avisá-lo, decidiu ir ao Incra em São Paulo para saber sobre o andamento da desapropriação da Fazenda, e naquela ocasião um funcionário de alto escalão do Incra tinha telefonado para seu celular perguntando quem era Edes, se Nino a tinha enviado e se podia dar as informações para ela. Para Nino, com esse telefonema o funcionário do Incra havia reconhecido que era ele e não outra pessoa o interlocutor com quem devia tratar dos assuntos da Fazenda em questão.

Edesmaria teve um percurso parecido com o do Nino pelo mundo das ocupações, mas, apesar de seu vasto currículo em ocupações e acampamentos, não conseguiu apoio para levar à frente um acampamento.

Edesmaria, antes de acampar no Famílias Unidas, em outubro de 2005 já havia passado por vários outros acampamentos. Ela e mais um grupo de doze famílias, depois de ter passado por acampamentos do MST e da CUT na região, haviam decidido sair da Cafeeira, a fazenda onde se encontravam acampados, e foram participar de uma ocupação na Fazenda Ipê. Nesse acampamento ela 
conheceu Donizete, com quem fez amizade. Ela, Donizete e mais um grupo de famílias acampadas ficaram menos de dois meses e saíram dali para fundar um acampamento.

Edes relata: "O Donizete, a primeira vez que eu vi ele, foi na ocupação da Fazenda Ipê e depois na Santa Cruz; nós montamos o acampamento Santa Cruz, ele é um dos fundadores do acampamento junto comigo, é como se fosse um irmão, tudo era combinado com ele, sabe, aquela pessoa de confiança".

Muitas vezes, o acampamento, como menciona Macedo (2003), pode se tornar o lugar onde homens e mulheres, considerando-se livres das submissões e das restrições morais em relação aos locais de origem, podem superar desilusões de todo tipo, ao encontrarem novos parceiros e amigos. Por outro lado, a confiança e as relações de amizade conformadas nesses espaços muitas vezes surgem por identificação, por sentir que aquela pessoa que compartilha o espaço do acampamento se encontra numa situação de vida semelhante.

Essas novas identificações e sentimentos de amizade podem ser determinantes para que os acampados tomem novos riscos fora da tutela de movimentos já consolidados e podem contribuir também para novos empreendimentos, novas mobilizações, que podem ser a base da conformação de novos grupos dentro do mundo das ocupações de terra.

Edesmaria, estando na Cafeeira, havia tido a oportunidade de ter contato com pessoas ligadas ao Sintraf, que por sua vez lhe haviam permitido ter contato com o prefeito e com os vereadores locais. Esse capital de relações, Edes começou a aproveitá-lo para beneficiar "seu acampamento". Assim, ela, Donizete e Xavier, outro acampado que conhecia "desde a Cafeeira", começaram uma empreitada entre prefeitura, vereadores locais e Incra, para conseguir apoio para seu acampamento; no entanto, o acampamento não deu certo e em menos de dois meses acabou, deram-se conta de que, para serem ouvidos, precisariam do apoio de um movimento.

Edesmaria me relatou:

[Quando] eu montei o acampamento, eu "tava" morando na Cafeeira e o pessoal falou de fazer uma ocupação na Fazenda Ipê, e de lá eu montei o acampamento, da Fazenda Santa Cruz; aí não 
deu certo, desmanchou o acampamento e eu levei doze famílias. (Acampamento Famílias Unidas, agosto de 2007)

No caso de Edes, seu tempo de acampamento a colocou numa posição de destaque diante de um pequeno grupo de acampados, e, sentindo-se confiante dessa sua posição, consegue fundar um acampamento; no entanto, suas proezas individuais e o capital social adquirido não foram suficientes para levar à frente seu projeto, para isso ela deveria ter também um movimento.

A necessidade de ter um movimento, como vimos, também foi percebido por Nino que não somente tinha um currículo de acampamentos igual a ela, mas diferentemente dela, havia acompanhado as atividades da militância do MST e o know-how da negociação e das relações nessa região, sua região de origem.

Edesmaria e as famílias que compunham seu acampamento acabaram se instalando no acampamento Famílias Unidas. Como já foi mencionado, foi Edes, junto com esse grupo de novos velhos acampados, que incentivaram a conformação de uma determinada forma de organização no acampamento. Nesse processo, algumas famílias que discordaram da nova organização saíram. De fato, a própria forma de acampamento pode ser também um dos critérios de mudança ou da saída dos acampados.

Esse foi o caso de pouco mais de 40 famílias que mantinham barraca com o Biro (MST) no próprio acampamento Famílias Unidas e que, em outubro de 2008, decidiram, algumas delas, sair do acampamento e outras mudaram de movimento, embora dentro do mesmo acampamento. Os principais motivos do racha foram, por um lado, a cobrança por parte do Biro do tempo de luta, isto é, a participação em jornadas (marchas, passeatas, ocupações de terras, ocupações de prédios públicos, bloqueios de estrada), e, por outro, a indicação, por parte do MST, desse militante, e não de outras famílias com mais tempo de acampamento, para ser assentado em uma Fazenda vizinha; 34 das 40 famílias decidiram acampar sob uma nova bandeira, a do Sintraf e escolheram Neguinho, um acampado filho de um assentado da região, como coordenador do grupo. O resto das famílias moradoras do acampamento negociaram uma vaga do Nino e passaram a acampar sob a bandeira do MTR. 


\section{2 \\ TEMPO DE LUTA}

No mundo das ocupações de terra, especificamente nos acampamentos organizados pelo MST, ter tempo de barraco não é suficiente para ser beneficiário de um lote de terra, ou, em termos nativos, não é suficiente para ser indicado para uma vaga num assentamento, também é preciso ter tempo de luta.

Comerford (1999), na sua análise sobre as reuniões de trabalhadores rurais, menciona que o termo "luta" pode ter diversos significados. Nos acampamentos da reforma agrária, tal como entre os trabalhadores rurais estudados por Comerford, o termo "luta" pode estar "intimamente associado à noção de sofrimento" (1999, p.19). Para a maioria dos novos e velhos acampados, é o sofrimento debaixo da lona o que legitima a pretensão de ter terra. No entanto, nos acampamentos de sem-terra, como apontado por Loera, o termo "luta" pode ter também outros usos e significados, que dependem do contexto e "do lugar que os agentes ocupam no ciclo da vida” (2006, p.98), e mais, depende da posição que ocupam no mundo das ocupações de terra e, especificamente, na hierarquia do movimento e/ou do acampamento, assim como também da constituição social desses espaços. No caso aqui analisado, o termo "luta", acompanhado da variável "tempo", para militantes do MST e acampados de acampamentos do MST pode 
significar também, ainda que de maneira diferenciada, a contabilidade da participação em marchas, ocupações, passeatas, congressos, entre outros eventos e performances coletivas organizadas pelo movimento.

Contudo, é importante mencionar que, para dirigentes de outros movimentos e participantes de acampamento organizados por outros movimentos que não o MST, o termo "luta" pode ter outros significados. Por exemplo, no caso do acampamento Famílias Unidas, que, como foi mencionado anteriormente estava dividido em três movimentos, MST, MTR e Sintraf, para os coordenadores e acampados sob as duas últimas bandeiras, o tempo de luta era visto como sinônimo do tempo de barraco e geralmente se referia ao tempo que se passa como morador debaixo da lona, no acampamento.

No caso dos militantes das regionais do MST e aqueles presentes nos acampamentos, o tempo de luta pode estar relacionado com o tempo dedicado ao movimento organizando ocupações, marchas e outras performances coletivas, com as pessoas e os recursos sociais que se consegue mobilizar nesses eventos e as negociações feitas em favor dos acampados perante representantes do Incra e outras autoridades dos governos locais.

Retomo a expressão "recursos sociais" inspirada na análise de Coradini (2001). Para esse autor, os recursos sociais, no contexto por ele estudado, de inserção de candidatos em posições político-eleitorais, seriam uma série de atributos sociais lidos também como "qualidades pessoais" ou de "liderança", "competência profissional, vinculação a sindicatos, exercício anterior em cargos públicos, valores morais, recortes territoriais, etc." (2001, p.7). No mundo das ocupações de terra, entre acampados e militantes, os recursos sociais estão relacionados, principalmente, com a capacidade de negociação, com a capacidade de mobilizar um capital de confiança e de relações e, no caso específico dos militantes, também com a capacidade de mobilizar acampados.

Para os novos e velhos acampados, o tempo de luta está relacionado, principalmente, com o número e tipo de mobilizações nas quais participaram, com as dificuldades que passaram e a maneira como 
participaram, assim como os recursos materiais e sociais investidos nas mobilizações e o tempo dedicado à mobilização.

Para a família dos Reis, por exemplo, a necessidade de cumprir com ou acumular tempo de luta se fez evidente logo nos primeiros meses de acampamento.

Como foi mencionado no "Preâmbulo", eles realizaram, em abril de 2002, a sua primeira ocupação na região de Bragança Paulista, na Fazenda Capuava, pertencente ao município de Atibaia, onde montaram seu barraco e passaram a ser acampados do Terra Sem Males.

Segundo Cleusa, quando acampavam "na Capuava”, ela e sua família acreditavam que seria fácil ganhar as terras, pois "achava que era só ficar debaixo do barraco"; entretanto, um primeiro episódio ocorrido duas semanas após a formação do TSM e as reações e relatos dos velhos acampados mostraram-lhe que o caminho era longo, e ainda teria que passar por muitas outras ocupações e mobilizações antes de pisar em terra própria. Ela relatava:

Um dia de noite [na Capuava], não sei o que aconteceu, um alarme falso, achando que as terra tinha sido ganho, acho que era meia-noite, a turma começava a gritar: "Essas terra é nossa! MST!". E gritou e gritou, não sei como gritava: "Aqui eu piso na minha terra!" O acampamento todinho se manifestou, estavam batendo e saindo para fora e um abraçando o outro, e "Ganhamos as terra!" Porque tinha vindo, eram umas 10h30, 11 horas, veio a Fatiminha [militante] e conversou lá e, quando ela saiu, aí falaram que tinha ganho as terras [...]. Então, aí quando foi o outro dia cedo, o capataz, que é um militante da Capuava, ali falou assim: "Mas por que a turma se manifestou desse jeito? Ganharam as terras mesmo?" Ali ele pegou e falou assim: " $50 \%$ sim, 50\% não". E todo mundo ficou feliz porque achou que ia ganhar essas terra aí, depois não falou mais nada, aí no outro dia mesmo falaram que [o alvoroço] tinha sido porque José Rainha tinha sido solto, porque ele é o cabeça mesmo dos sem-terra, né, do MST, aí eu falei: "Ah, meu Deus do céu, se fosse isso então"..., mas fizeram uma farra mesmo. (Acampamento TSM, Cajamar, maio de 2003) 
O desânimo foi uma das primeiras reações de alguns novatos, logo depois que souberam que a comemoração de alguns militantes havia sido não pela suposta liberação das terras, mas pela liberação de uma das lideranças do MST que havia sido presa uns dias antes. Já, para os velhos acampados, "a farra" e as reações dos novatos foram motivos de gozação, mas também de distinção entre experientes e inexperientes do mundo das ocupações. Gracilda, uma velha acampada, mas nova acampada do TSM, lembrava-se daquele episódio que me foi narrado por Cleusa, a qual me explicou que aquilo havia provocado risos e reações de outros velhos acampados, ao ouvirem os novatos comemorando o boato de que haviam ganhado as terras. Gracilda e outros velhos acampados sabiam que, tão somente a duas semanas de terem feito a ocupação na Capuava e montado o acampamento, era impossível entrarem nas terras. ${ }^{1}$ Ela, com quase quatro anos de acampamento, havia aprendido não só a etiqueta e/ ou o ritual seguido logo após uma ocupação: reintegração de posse, despejo, desmanche do acampamento, deslocamento das famílias e reocupação, mas também que aquela ocupação era só o começo para alguns, era uma de tantas outras; os novatos ainda teriam que acumular um tempo considerável de luta antes de serem assentados. Como ela me disse, ao relembrar aquele episódio: "[os novatos] não sabiam que ainda tinham muitas ocupações pela frente".

\section{As dificuldades}

Só no decorrer de um ano, as famílias do TSM fizeram mais três ocupações, além de participar de outros atos e protestos organizados pela militância da Regional de Campinas do MST, que foram realizados em cidades próximas de onde se encontrava o acampamento. ${ }^{2}$

1 Como anteriormente mencionado, essa expressão se refere ao momento em que acampados conseguem ser assentados.

2 Ver em Anexo, no Mapa 2, a cronologia de ocupações desse acampamento. 
Uma das mobilizações que marcou várias famílias do TSM foi a ocupação em Franco da Rocha, destino de algumas famílias depois de terem saído da Fazenda Capuava. Essas famílias, principalmente as que já contavam com tempo de acampamento, avaliaram aquela ocupação como uma das mais sofridas, sobretudo pelo tempo que passaram num lugar considerado por eles perigoso e pelas dificuldades que sofreram, especialmente para conseguir recursos básicos para sobreviver dentro do acampamento.

A própria Gracilda narrava da seguinte maneira a chegada em Franco da Rocha:

Ali [os militantes] chegaram só e não avisaram para nós nada, falaram que era em Franco da Rocha, só que eles não avisaram, falaram que a gente ia mudar, falaram que era garantido, que ninguém ia tirar, que era uma ocupação que já estava certa, Aí nos fomos sábado, aí a Prefeitura concedeu dez caminhão de mudança, aí mudou tudo bonitinho, tudo certinho, cada um arrumou no caminhão. Aí, menina, quando nós chegamos lá, um lugar feio! Porque o acampamento ficava dentro do mato, lá dentro do mato, assim, e tinha aquela pista, aquela estrada que subia pro presídio e a estradinha que entrava lá pros sem-terra [para um assentamento]. Aí, quando nós chegou lá, já tava aquele alvoroço, porque tinham matado um homem da Capuava que tinha ido lá três dias antes para ajudar a cavar um poço, porque veio uma turma antes para cavar o poço, porque não tinha água lá e o cara matou, degolando-o com um facão (TSM, Cajamar, abril de 2003).

No depoimento de Gracilda, ela enfatiza que o "feio" da ocupação em Franco da Rocha estava no fato de o acampamento ficar "dentro do mato", num local onde, além de não ter água, havia dificuldade para chegar e para sair e também no fato de ter acontecido um assassinato naquele local. Seu Marcos, um novato do TSM que, em Franco da Rocha, realizava a tarefa de vigia do acampamento mencionava como dificuldade o isolamento e a proximidade com o presídio, para ele era um lugar onde "não tinha para onde correr". 
Dias depois da ocupação em Franco da Rocha, correu o rumor de que havia três presos fugitivos do presídio próximo e que poderiam estar escondidos dentro do acampamento, disfarçados de "novos acampados". Aquilo confirmou as dificuldades dessa mobilização e o desejo dos acampados de não ficar naquele local.

As famílias do TSM ficaram só um mês e meio em Franco da Rocha; segundo relatos de vários acampados, por causa das dificuldades acima anunciadas muitas famílias desistiram da luta. As que ficaram, entre elas a família dos Reis, começaram a pressionar os militantes do MST da Regional de Campinas para que as tirassem daquele lugar.

As dificuldades vivenciadas durante as mobilizações (ocupações, marchas, passeatas) são consideradas uma forma de legitimar o tempo de luta. Acredita-se que aqueles que arriscaram mais e passam mais dificuldade, de alguma forma acabam acumulando mais tempo de luta. Por exemplo, uma marcha ou uma ocupação na qual passam penúrias, sentem fome e, muitas vezes, medo por causa de despejos, ou por outros motivos, valem mais, ou contam mais do que outras mobilizações. O comentário de um acampado do TSM é significativo a esse respeito. Beto mencionou que acreditava que algumas famílias que tinham saído do TSM para participar de uma ocupação e montar um acampamento na região noroeste de São Paulo seriam rapidamente assentadas, já que estariam passando muita dificuldade.

Por outro lado, as ocupações que acontecem de maneira pacífica, nas quais é fácil se locomover para cidades próximas e se tem acesso facilmente aos bens essenciais do mundo das ocupações, comida, água e, principalmente, lona preta e bambu, materiais básicos para montar o barraco, são menos lembradas pelos acampados, mas ainda assim são contadas na hora de fazer referência ao tempo de luta.

Na reconstrução dos fatos das mobilizações e principalmente das ocupações vivenciadas, as famílias originárias do TSM colocavam também em destaque, como parte das dificuldades, a perda de bens 
materiais. Cleusa e Antônio coincidiram em afirmar que, a cada ocupação e mudança do acampamento, os poucos bens que tinham foram-se perdendo no caminho.

A saga de ocupações que finalmente culminou na formação do acampamento Dom Hélder Câmara foi considerada pelas famílias que já tinham um tempo de acampamento uma das mobilizações mais desorganizadas das quais participaram e atribuíram as dificuldades daquela mobilização à perda de bens materiais, aos imprevistos que surgiram durante a mobilização e ao tempo que demoraram em se estabelecer num local. ${ }^{3}$ Devo especificar que não necessariamente uma ocupação corresponde a uma só mobilização, uma sucessão de ocupações num espaço curto de tempo pode ser considerada uma mobilização ou várias.

Retomemos, então, os relatos de alguns acampados que narram as dificuldades vivenciadas durante a saga de ocupações anteriormente mencionada - que durou ao todo onze dias -, desde o planejamento da mobilização até a conformação do acampamento Dom Hélder:

No Terra Sem Males, a gente teve várias reuniões, e o Jorge [militante], no Irmã Alberta [acampamento vizinho ao TSM] falou assim, que estava surgindo um acampamento lá na região de Andradina e quem quisesse vir ia começar tudo de novo, mas quem quisesse poderia vir para a região de Andradina. Jorge falava assim para mim, para mim só não, para todo mundo: "É só chegar, nós vamos acampar, fazer uma grande ocupação e, quando a gente sair dessa ocupação, nós vamos entrar já direto numa fazenda para ser assentado" (Edesmaria, acampamento Dom Hélder Câmara, julho de 2003).

O Jorge falou assim na assembleia... [no TSM], tanto quando teve assembleia na Terra Sem Males como lá na Irmã Alberta,

3 Saíram de Cajamar e fizeram ocupação na Fazenda Pau d'Alho, depois na Santa Rosa e na Araçá, todas elas no município de Araçatuba, e finalmente ocuparam uma fazenda em Brejo Alegre, próximo à cidade de Birigui. 
falou: "Quem quiser ir para Andradina vai, nós vamos ocupar uma fazenda lá, vai ser a fazenda onde vocês vai fazer a ocupação". Eles fala festa, né, "vai ser uma grande festa e vai ficar na história"; ele falou assim: "Vai ficar na história, depois dessa ocupação, dessa grande festa que vai ter, que vai acontecer, porque nos vai chegar lá e pode ser que num minuto, 15 minutos, nós já seja despejado ou até no máximo 24 horas vai ser despejado. Mas o que que vai acontecer, nós vai sair dessa fazenda e nos vai acampar em frente". Nem dentro não foi, "nós vai acampar em frente, numa fazenda que já tá desapropriada que provavelmente vai ser nossa”, ele falou desse jeito, e todo mundo que veio caiu na besteira, porque já tava falando assim: "Nós vai ser assentado". O dia 30 [de junho] nós saímos de lá de noite, da Terra Sem Males, nós saímos e era 10 horas. Até chegar esse ônibus, eu acho que era mais de 10 horas, sei lá. Com toda a bagagem, quando esse ônibus veio tava lotadinho, dava até medo. Vinha aquele ônibus, todas as gavetas lotadas, o motorista disse que não cabia uma pena de galinha dentro, veio até caixa de galinha, eu sei que demorou sair de lá, ainda contornamos aquela estrada para sair e não passar aquela balança, até chegar em Campinas, naquele ponto que... porque veio ainda sete pessoas em pé dentro daquele ônibus, para passar para outro ônibus, quando chegasse em Campinas, né; quando chegou num posto rodoviário que tinha lá, não sei aonde aí passou, e foi cortando para vir embora, chegou em Campinas. Do [acampamento] Irmã Alberta estavam nos esperando em Campinas, ah, e veio tudo junto, até os caminhão de mudança tava também esperando, chegou também tudo junto. Quando nós chegamos [na primeira fazenda] tavam [os militantes], tava um monte, "ah, que a fazenda! aqui é ótima”, nos já entrou, já tava certo, eu falei: "Tudo bem, né". O dono passou, né, cumprimento todo mundo, ficava na casa do caseiro, né, e lá, menina, sem bambu para fazer barraco, quem chegou cedo arrancou e pegou os últimos que tinha [...]. Eram [no total] 103 pessoas, famílias, fora os apoio que veio de Andradina, veio muita gente de Andradina que já foram assentadas, aí veio até um padre de lá [de Andradina], aí, quando foi de noite, fizeram uma assembleia, aí falaram que 
íamos ficar na frente de uma outra [fazenda]. Carregamos as coisas até na cabeça, aquele dia eu fiquei... falei para ele [o marido] que ia pôr fogo no barraco, que eu ia sumir de a pé, mandei ele para os quintos infernos, fiquei nervosa e aí ele falou assim: "Então vamos pôr fogo, vamos embora". Mas o Gugu militante falou assim: "Vamos carregando de pouquinho em pouquinho até nós entrar na fazenda". O que que aconteceu, ninguém seguiu as ordens [do Gugu], todo mundo se apavorou e já foi carregando e entrou e foi arrancar aquela cerca e entraram não sei quantos, aí virou aquela bagunça. [...] Tinha uns [acampados] que não prestava, só tava ali para fazer bagunça, eles [os militantes] não souberam controlar o povo, trouxeram uns [novatos] sei lá de onde, foram mobilizados pelo pessoal [militância] de Andradina. [...] Passou terça, quarta, quinta, sexta, sábado, na sexta-feira chegou a liminar e o pior é que não vai um camburão, não vai dois, três [...] Quando foi na sexta-feira, fomos lá na Câmara Municipal com o vereador e eu fui convidada para entrar junto, né. Aí eu vi o Luiz pegando a liminar assim e nós lemos, até então nós não estava sabendo, aí, quando nós viemos, já a Laís pegou e falou: "Já temos a liminar de despejo, nós temos 24 horas para sair”. Aí eles tentaram tudo quanto é jeito para ficar lá, aí não conseguiram, não souberam negociar. Aí na sexta foram para Araçatuba, para ligar pro Jorge [militante da Direção Nacional do MST]. Aí, quando foi na sexta-feira, não no sábado, foi uma assembleia, e falaram, foi na segunda-feira mesmo nos já mudamos, aí foi que veio essa turma, aí, quando foi na terça-feira cedo, teve uma assembleia, quando foi na segunda-feira de noitinha, já aí chamaram para explicar que nós ia sair; aí ele falou nós vamos sair daqui, 20 quilômetros longe da fazenda, e amanhã cedo já nós vai começar a sair, né, e começou cedo, menina do céu! Aí cedo teve outra assembleia e tinha uma fila como daqui lá naquele mato, tinha Corpo de Bombeiro, ambulâncias, tudo isso, falei: "Gente, o que que está acontecendo aqui, né". A polícia tava entrando. Aí nós fizemos o cordão assim comprido, né, com todo mundo beirando o feijão assim e nós todos de mão dada assim, na frente de todos os camburão, os policial que tava lá e todo mundo 
rezou o Pai-Nosso naquele cordão; assim, aí todo mundo desceu para arrumar suas coisas, aí, dali a pouco foi chegando o caminhão, aí foi dois caminhão para trazer os bambu e dois caminhão para carregar a mudança, porque nesses caminhão não cabia nada, não cabia nada nesses caminhão tudo pequenininho, até que por fim aí apareceu uma vereadora que nós tínhamos conversado com ela lá na Câmara Municipal, aí arrumou uma carreta, uma, mais não coube tudo, aí veio mais outro caminhão, aí veio aqueles caminhão carregando as coisas, caminhando, caminhando, carregando, carregando, tava lotado de ônibus, foi 4 ônibus, 3 para trazer as pessoas, aí um povo tinha saído, tinha ido embora, não tavam confiando mais. [...] E, quando chegamos aqui, foi aquela montoeira de coisas, ninguém sabia que era de quem, apesar que nossas coisas... o Tiago [filho] deixou para carregar bem por último e foi a justiça que ajudou, porque o Tiago falou: "Não jogue em cima de tudo, minhas coisas e as coisas do meu pai vai ser por último e tem lugar para pôr, já quebraram minha cama e agora não vão quebrar a da minha mãe". Já, quando chegou aqui, foi descarregando e, quando chegou aqui, nós separamos assim, minhas coisas lá do feijão veio na carretona. Minha bolsa sumiu com meus documentos. Aí eu falei; "Mas, se sumir coisa, meu, eu entro em tudo quanto é barraco". As pessoas falavam "aqui é tudo meu”, puxava um da mão do outro, isso aqui é meu, não sei que lá. Então nós no meio daquela bagunça, nós separando tudo lá na beirada, as minhas coisas e a do Tiago, ah, menina! Mas isso aí pra dormir lá na beira da pista, aí nós pôs a grade da cama assim no chão, joguemos e... aquela terra vermelha, sujando tudo, e nós naquela bagunça. Aí de manhã eu levantei, né, e falei: "Ah, nós vamos ficar aqui mesmo". Bem tranquila, né, quando puis o fogão, fui ver, o fogão tava tudo quebrado, quebraram tudo (Cleusa, acampamento Dom Hélder Câmara, julho de 2003).

Quando chegamos na outra fazenda [Santa Rosa], deu uma chuva de vento, uma chuva de vento que, pronto, quase levou todos os barracos, tudo mundo molhou as coisas, molhou tudo, o col- 
chão da cama, mas virou aquela coisa, pelo amor de Deus! Foi forte mesmo. Não tinha para fazer o barraco, você acredita? Aí, depois, assim no chão os colchão tudo molhado, tudo molhado, aí, quando foi no outro dia, aí desmanchou tudo de novo e aí fiz um barraquinho bem-feitinho, bem durinho, nossa! E já no outro dia, dois dias, de novo desmancha o barraco, carrega tudo de novo [...]. Tava assim de polícia, bombeiro, ambulância, motoqueiro, quando nós levantamos assim do banco do ônibus para olhar, aquilo era polícia, motoqueiro, Corpo de Bombeiro e ambulância; falei: "Gente, mais isso aqui!". Ali que eles [os militantes] se dividiram, uma parte na frente, uma parte atrás e uns poucos para os meios, sabe, mas, como nós viemos, o ônibus pegou Araçatuba, que aqui já é mais movimento, achamos que eles tinha se descartado e ido embora um pouco, né, quando nós passamos no ponto do retorno ali, saímos de Araçatuba, para entrar em Birigui, enquanto sai de em cima do ponto, enquanto você sai de em cima e sai por baixo assim, aí que nós vimos, só tinha estrada com polícia, tudo de sirena acesa e andando e andando e andando, falei: "Puta que o pariu! O que será isso?”. Nós cheguemos aqui de noite, né, escuro, era 8 horas da noite, quando nós cheguemos, aí uns veio e encostou aí mesmo, na entrada, aí falaram que não queriam que porque era no meio do mato, que não sei o que lá e não ficaram, ninguém quis ficar ali achando que era um matagal, sabe. Nós desceu ali, nessa estrada ali; dali o Gugu chamou só os homens, só os homens, as mulheres não, e falou assim: "É o seguinte, aqui não tem cachorro, tem gente, tem mulher, tem criança e todo mundo aqui é gente, tem direitos iguais". Falou para polícia, pro major: "Oh, major, se o senhor quiser me prender pode me prender agora, mas só enquanto o senhor não arrumar 120 marmita para dar comida aqui pro pessoal, nós não vai liberar o ônibus, nós vai liberar só dois. Nós vai ficar com o ônibus até a marmita chegar, porque, enquanto não chegar, nós não vai liberar o ônibus, não, vai liberar todos, mas um vai ficar". Foi tipo um sequestro e os motorista de ônibus louco, dava até dor de ver, porque eles não podia ir embora, todo mundo descarregou, a carreta descarregou tudo e eles ficou, encostou lá na beira da pista 
e, do outro lado de lá, era só polícia e polícia, aí demorou, demorou, demorou, todo mundo com fome, né, porque nós tinha feito, tinha comido era 10 horas da manhã. [...] O Gugu foi corajoso, enfrentou a polícia por nós. Ele negociou direitinho com eles. O pessoal novo [novatos] não o conheciam, mas, quando enfrentou... passaram a confiar nele. O pessoal tava desconfiado, já era muito despejo e muda para cá e muda pra lá, mas o pessoal viu que podia confiar. (Antônio, acampamento Dom Hélder Câmara, julho de 2003)

Nos depoimentos acima, relata-se não somente o processo de mobilização das pessoas e das sucessivas ocupações, mas, na percepção desses acampados, o medo, a incerteza, a desordem, a presença de agentes externos aos sem-terra, a inexperiência dos novos acampados, a falta de bens básicos do mundo das ocupações, a perda de bens materiais e o tempo passado se deslocando de um lugar para outro conformaram também as dificuldades daquela mobilização. Por outro lado, essas dificuldades foram se atenuando no momento em que se fez uso de certos recursos sociais: quando o capital de relações foi acionado com militantes da Nacional do movimento, o vereador ou a vereadora, e, também, no momento em que os militantes que acompanharam a mobilização fazendo uso das suas competências pessoais conseguiram negociar com as autoridades em favor dos acampados e quando, graças ao conjunto desses recursos mobilizados, a confiança foi restituída.

No mundo das ocupações, a capacidade de negociação dos acampados ou dos militantes e a capacidade de estabelecer vínculos com autoridades locais são vistas como algo inerente às capacidades e proezas individuais, no entanto, conforme vimos, a negociação só se torna possível quando ambas as partes estão dispostas a estabelecer um vínculo e um acordo; e só se a negociação tem sucesso é que as capacidades individuais ou proezas aparecem.

Por outro lado, se as dificuldades vivenciadas durante as mobilizações são consideradas pelos acampados uma condição sine qua non do tempo de luta, a confiança aparece como uma dádiva, como 
algo que é dado e pode ser cobrado, tornando-se um dom e contradom fundamental, para que os acampados "vão à luta".

Inclusive, também no processo de mobilização de famílias novas, a confiança é um valor fundamental. A maioria dos novatos só se instala debaixo da lona quando alguém conhecido, e em quem eles confiam, os convida ou lhes fala sobre a experiência do acampamento. No caso da formação dos acampamentos TSM e Dom Hélder, as famílias novas que constituíram esses acampamentos foram mobilizadas por militantes, assentados ou acampados das regiões onde os acampamentos foram instalados, pessoas que já se conheciam. Esses militantes, acampados ou assentados, ou já contavam com a confiança das pessoas convidadas ou essa confiança foi sendo ganha com um trabalho de base contínuo e com um grande investimento de tempo.

Sigaud, Rosa e Macedo (2008) demonstram que, nas primeiras ocupações realizadas em Pernambuco organizadas por sindicalistas, o capital de confiança acumulado em relação aos trabalhadores foi fundamental, e de fato decisivo, para que moradores dos engenhos se instalassem em acampamentos montados em terras dos patrões.

Seu Zé Antônio do TSM, por exemplo, sabia da importância da confiança para convencer pessoas a irem à luta, segundo ele, é precisamente a retribuição da confiança depositada, principalmente nos militantes, o que faz com que os acampados pensem: "a militância de lá é uma beleza, a militância de lá é isso, eu confio no movimento, confio nas pessoas que tão lá trabalhando". E de fato, muitas vezes, quando a confiança não é retribuída, a não retribuição pode se tornar uma das razões para "desistir da luta".

Esse foi o caso da própria família dos Reis. Como já foi mencionado, depois de ter ficado pouco mais de um ano acampada em Birigui no Dom Hélder Câmara, essa família, a convite de Cláudio, um sindicalista da região, aceitou participar de uma ocupação na Fazenda Cafeeira na região de Andradina. A família dos Reis e mais 22 famílias saíram do Dom Hélder pensando que logo seriam assentados. No entanto, segundo Cleusa, Cláudio "não é pessoa 
confiável", para ela, as famílias confiaram nele e nas palavras dele e acreditaram que, como ele lhes disse, a fazenda já havia sido liberada, porém, segundo ela, "ele contou mentiras", pois usou as famílias para movimentar. ${ }^{4}$ Lembremos que, muitas vezes, os acampamentos são vistos pelos acampados como se tivessem donos, e, para aqueles que assim se percebem, ter um acampamento é também uma maneira de adquirir certo prestígio. Como enunciado por Rosa (2011), no mundo das ocupações de terras há concorrência entre movimentos, e, muitas vezes, fazer uma ocupação e levantar um acampamento sob a bandeira de um determinado movimento é uma forma de marcar presença numa determinada região.

A família dos Reis acabou ficando quase um ano na Cafeeira, mas, como Cleusa mencionou, "perdeu a confiança nos dirigentes", ela fazia referência àqueles com os quais teve contato e que coordenaram as ações, as mobilizações e os acampamentos nos quais participaram. O desânimo se instalou na família, que acabou "desistindo da luta". 5

\section{Os recursos e as correrias}

Como relatado por acampados, nas mobilizações tanto os acampados quanto os militantes fazem uso de certos recursos sociais, acionando relações com parentes, prefeitos, vereadores, comerciantes e outras autoridades locais, pedindo ajudas em forma de comida, lona, transporte, para que as mobilizações aconteçam. Vimos no item anterior, tanto no depoimento de Antônio quanto no de Cleusa, em que momento e como certos recursos foram acionados. No caso do primeiro depoimento, o militante que liderava a ocupação negocia marmitas com um policial para os participantes da ocupa-

4 É comum, nos acampamentos, ouvir a expressão movimentar, para fazer referência ao fato de mobilizar pessoas para participarem de uma ocupação, marcha ou qualquer outra forma de protesto. Também se usa "criar movimento".

5 Esse episódio será tratado com detalhe no próximo capítulo. 
ção e, no caso do segundo, o contato com uma vereadora foi fundamental para conseguir o transporte e levar os pertences das pessoas para o local da próxima ocupação.

No caso do TSM, quando da ocupação em Franco da Rocha, a Prefeitura de Atibaia concedeu alguns caminhões para transportar a mudança dos acampados até o local da próxima ocupação, como narrado anteriormente.

Um ano depois outros recursos sociais seriam mobilizados. Quando o TSM saiu de Cajamar, militantes da Regional de Campinas negociaram com assentados de Sumaré II, para que as famílias desse acampamento ocupassem uma parte de um terreno do assentamento que se encontrava na beira da estrada. Alguns meses depois, já em terras do Sumaré II, os coordenadores do acampamento negociariam com representantes do Itesp e do Incra as condições do deslocamento das pessoas, o transporte e o lugar para onde as famílias seriam levadas e realocadas em caso de despejo. ${ }^{6}$

No caso do acampamento Famílias Unidas, o coordenador do MTR e velhos acampados mantinham contato pessoal com o prefeito da cidade próxima ao acampamento e, quando precisavam, negociavam com ele para conseguir carro ou transporte para mobilizar os acampados.

Edesmaria explicita essa relação da seguinte maneira:

A Prefeitura apoia muito o acampamento, muito mais, assim, se surge uma viagem, se alguém precisar de um ônibus para fazer uma viagem, essas coisas assim, transporte para São Paulo para ir pro Incra, isso ajuda muito, o prefeito ajuda muito, o prefeito é pessoa muito interessante, pessoa muito boa, o primeiro amigo da cidade; se você falar "gente como que você conheceu o seu primeiro amigo da cidade, o prefeito", foi assim, fora da coordenação do acampamento, o prefeito é uma pessoa muito especial para mim, muito, muito, muito, uma pessoa muito legal, amigo. (Edesmaria, agosto de 2007)

6 Para uma análise mais detalhada sobre esses acordos ver Loera, 2009. 
Macedo (2003, 2005), Rosa (2000), Barra (2007) e Sigaud et al. (2008) também relatam, para o caso de mobilizações no Rio de Janeiro, na Zona da Mata Pernambucana, na região de Campinas e no Rio Grande do Sul, respectivamente, a existência de acordos e negociações entre trabalhadores, representantes de movimentos, autoridades locais e representantes de órgãos de governo encarregados das desapropriações.

Rosa (2000), no seu estudo de caso sobre as relações sociais entre assentados e municípios receptores em Porto Alegre, menciona que estas a e prefeitura local encerram um amplo leque de significados, no entanto, na maioria das vezes, essas relações são estabelecidas sob a base da reciprocidade, mesmo se a balança do poder pende, é claro, para um lado, e se, ainda, nessas relações são colocados frente a frente diferentes universos de valor.

No caso das relações entre acampamentos e prefeituras, não é muito diferente. Em entrevista, em janeiro de 2009, com o recém-eleito vice-prefeito de uma cidade próxima ao acampamento Famílias Unidas, o tema das ajudas e dos recursos para os acampamentos surgiu na conversa. ${ }^{7}$ Para ele, era um tema que não devia ser falado em público, no entanto, aceitou falar: "as ajudas existem como acordos informais entre movimentos e prefeitura". De fato, ele mencionou que a nova administração pretendia oficializar esses acordos, criando uma estrutura na prefeitura para atender um público específico, os sem-terra.

Se, por um lado, para o vice-prefeito, os sem-terra geram despesas para o município (já que a prefeitura apoia os acampamentos principalmente com água, transporte para levar as crianças até as escolas e transporte para o deslocamento de lideranças e outros recursos para as mobilizações) e não necessariamente essa população retribui à prefeitura, pagando impostos, por exemplo, por outro, acampados na forma de assentados potenciais representam uma possibilidade de captação de recursos para o município, recursos na forma de verbas do estado, mas também uma possibilidade de

7 A administração dessa cidade era composta pela coligação dos seguintes partidos: PTB, PT, PV, PCdoB, PR, PDT, PSC, PRP. 
acumular capital simbólico, os acordos, o vice-prefeito deixou claro, são feitos com o MST, já que, segundo ele, "é um movimento que trabalha melhor e tem mais articulação política, mais relações”. ${ }^{8}$

A crença de que o MST é um movimento mais experiente no mundo das ocupações de terra, consegue negociar melhor e tem mais relações não só circula entre representantes de governo e, inclusive, entre as próprias lideranças do MST e de outros movimentos, como vimos anteriormente, como também circula entre acampados.

Seu Joaquim, por exemplo, acampado do Famílias Unidas, no contexto do último racha no acampamento, decidiu ficar "no grupo do Biro", pois para ele "o MST é um movimento que tem mais força”, e estando com eles teria mais possibilidades de ganhar terra, no entanto, completou: "as pessoas que ficaram do lado do Nino ou do Neguinho também vão ganhar as terras”, pois concordava com o que mencionara o coordenador do MST do acampamento: "os outros pequenos movimentos estão sempre sob a aba do MST".

Biro, apelando para a experiência que o MST acumulara ao longo de anos de luta, questionava o papel de movimentos como o MTR, que "exige que os acampados morem no acampamento, mas não exige que participem da luta”, isto é, das jornadas ou mobilizações. Segundo esse militante, nem todo mundo tem uma visão do que é "trabalhar para o coletivo". Ele me dava como exemplo a negociação das áreas. Para ele, o objetivo de uma mobilização era o de fazer pressão para reivindicar a desapropriação "de todas as áreas da região”, não somente uma, que, na visão dele, é o que o MTR fazia.

Muitas vezes, acampados como seu Joaquim, ao almejar os bens disponibilizados pelo Estado, como no caso das terras, decide ficar num acampamento organizado pelo MST, apelando ao prestígio desse movimento, ou seja, sua decisão de ficar com o MST passa

$8 \mathrm{O}$ vice-prefeito também mencionou a importância que teria para o município que os acampados "de fora" mudassem o título de eleitor para sua cidade. Afinal isso também é necessário para esses acampados poderem usufruir dos serviços do município, como saúde e educação, por exemplo. Ver, em "Anexo" (documento n.1), o informativo da campanha do prefeito, em que os acampamentos do município são vistos como parte do "grande potencial agrário" e contados também junto com assentamentos, como o alvo de novos projetos. 
pela posição e pelas "chances" que acredita que esse movimento tem no mundo das ocupações. Por outro lado, lideranças dos acampamentos também apelam ao que poderíamos chamar da crença no prestígio para conseguir as ajudas ou mobilizar os chamados recursos.

Entre os diferentes grupos de acampados do acampamento Famílias Unidas, tal como menciona Rosa para o caso dos assentados e os habitantes do município, por ele estudados, "conhecem e reconhecem os caminhos 'tradicionais' para a obtenção de serviços públicos como educação, saúde e obras de infraestrutura. [No entanto] Conhecer o caminho não significa que todos os moradores locais [no nosso caso, acampados] tenham a mesma condição de acesso aos serviços públicos, ao contrário, isto implica também reconhecer que existem vários modos de obter e receber tais benefícios" (2000, p.117). Ainda, segundo o autor, mesmo dependendo da posição social ocupada, com o tempo, os indivíduos "são capazes de reconhecer quais os atributos necessários para que suas demandas sejam atendidas" (2000, p.117). Em outras palavras, com o tempo, o indivíduo, "pela socialização, é capaz de reconhecer e ter reconhecida sua posição dentro da figuração social” (2000, p.117). No caso dos acampados, vão apreendendo a linguagem de demanda, a forma de reivindicar benefícios ou serviços ao Estado.

Na prática, alguns acordos entre prefeituras e movimentos são estabelecidos tendo como base essa crença de que o MST teria uma posição de destaque no mundo das ocupações de terra, todavia, esses acordos também são estabelecidos dependendo da posição que os próprios representantes dos governos locais ocupam no mundo da política e dependendo da própria organização e constituição social dos acampamentos.

No caso da administração da cidade próxima ao acampamento Famílias Unidas, por exemplo, os acordos eram preferentemente estabelecidos com lideranças do MST, no entanto, na administração anterior, o prefeito do PSDB, segundo depoimentos de acampados e dos próprios militantes do MST da região, preferia estabelecer acordos com outros movimentos, que não o MST, no caso específico do acampamento Famílias Unidas, com as lideranças do MTR. 
Teresa, acampada no Famílias Unidas, falava que essa "preferência" da administração anterior se refletia inclusive no atendimento aos acampados no centro de saúde da cidade. Segundo ela, que durante meses havia ficado acampada no grupo do MST, quando queriam ser atendidos no centro de saúde, os acampados do grupo do MST deviam pedir uma declaração de Nino (coordenador do MTR), em que constasse que eram acampados do MTR. Lembremos que, como a regra desse movimento era de morar no acampamento, a declaração servia como um comprovante de residência no município, diferentemente da população de acampados andorinhas do MST, que não necessariamente residiam no município. Conforme Teresa, pedir uma declaração do MTR, mesmo estando acampada "do lado do MST", foi a estratégia por ela adotada para receber um serviço da prefeitura depois de ter tido uma má experiência no centro de saúde. Ainda segundo essa acampada, um dia, ao querer marcar uma consulta, ouviu uma enfermeira dizendo para outra: "ela é do Biro" (coordenador do MST do acampamento Famílias Unidas). E depois negou o atendimento, completando: "fale para o seu coordenador vir aqui". Dércio, outro acampado, mencionava que na administração anterior qualquer trâmite na cidade acabava sendo mais fácil estando "do lado do Nino", pois o cadastro de acampado e documentos apresentados eram feitos em papel timbrado do MTR com o endereço do acampamento.

No caso do acampamento Famílias Unidas, principalmente os velhos acampados aprenderam o know-how da negociação para conseguir e mobilizar recursos, mas principalmente aprenderam o que devia ser feito para conseguir benefícios da prefeitura, no caso que relatamos de Teresa, por exemplo, para ser atendida mais rapidamente no centro de saúde, pediu uma declaração de Nino, coordenador do MTR do acampamento, em que constasse que ela era acampada do MTR. ${ }^{9}$

Devo especificar que, no caso das pequenas cidades próximas aos acampamentos, para os funcionários das prefeituras, comer-

9 Ver em "Anexos" (documento n. 2 - Declaração de residência e filiação ao MTR). 
ciantes e em geral habitantes dessas cidades, os movimentos (MST, MTR, Sintraf, CUT) são percebidos através das suas lideranças, pessoas de carne e osso, como Biro ou como Nino, que coordenam os acampamentos.

No caso específico do acampamento Famílias Unidas, as lideranças eram conhecidos de longa data, ou já mantinham, antes de se tornarem lideranças dos movimentos, uma relação de proximidade com algumas autoridades locais. Esse é o caso do próprio viceprefeito antes mencionado e de Nino, coordenador do MTR.${ }^{10}$ Por serem da mesma cidade, o vice-prefeito tinha uma relação de proximidade com Nino, e, de fato, parecia conhecer bem a trajetória dessa liderança pelo mundo das ocupações de terra.

De outra forma, e independentemente das relações de proximidade entre autoridades locais e lideranças dos movimentos que não o MST, a crença na posição de destaque desse movimento no mundo das ocupações de terra circula também entre as lideranças de outros movimentos.

No caso do acampamento Famílias Unidas, para os coordenadores do grupo do MTR, a concorrência com o MST não era fácil, segundo Maria, coordenadora e esposa de Nino: "o problema dos militantes do MST é que acham que, por serem do MST, podem tudo". No entanto, Nino completava: "Eles têm o conhecimento, mas acampamento não têm”. Fazendo referência ao fato de que quase não existiam acampados ou moradores nesse acampamento sob a bandeira do MST mas só apoios.

Nino e Maria guardavam no seu barraco, como se fosse um tesouro, uma pasta com o cadastro de todos os seus acampados. Durante as várias visitas de campo ao acampamento faziam questão de abrir a pasta e mostrar não só os novos cadastros em papel timbrado com o logotipo do MTR, o endereço do acampamento, como a declaração de fundação do movimento, a impressão de cada uma das etapas do processo de desapropriação da fazenda baixadas da internet e decla-

$10 \mathrm{O}$ vice-prefeito conhecia inclusive episódios pessoais da vida de Nino. Nesta ocasião não tratarei desse assunto, mas interessante é indagar sobre as condições sociais e escolhas individuais que levaram essas duas figuras públicas da cidade a traçar caminhos diferenciados. 
rações de mudança de movimento dos acampados. Peirano (2002) chama a atenção para o reconhecimento social que têm os documentos, os papéis, na nossa sociedade. Para ela, os documentos fornecidos por uma autoridade administrativa, por exemplo, teriam uma espécie de poder (mágico) que valida ou reconhece os indivíduos como parte de uma coletividade. Ainda, segundo a autora, os documentos permitem a contagem dos indivíduos, ao mesmo tempo em que os singularizam (2002, p.45). No caso das lideranças do MTR, a posse dos papéis antes mencionados, assim como a exigência de uma carteira de identificação dos acampados com a data de filiação ao movimento, era uma forma de se diferenciar dos coordenadores do MST do acampamento, mas, ao mesmo tempo, uma maneira de mostrar semelhança ao modo como esse movimento é percebido pelos acampados. Como Maria me disse, eles pretendiam mostrar que eles "também são organizados", que são "um movimento sério". Dessa maneira, os acampados se sentiam mais seguros com respeito ao trabalho deles, dos dirigentes do MTR. Por outro lado, as declarações e carteirinha fornecidas pelos coordenadores do MTR, como descrito nos depoimentos de Teresa e Dércio anteriormente citados, também eram reconhecidas por funcionários da prefeitura como um documento legítimo para usufruir dos serviços públicos do município. Inclusive, como relatado por acampados, esses mesmos documentos também eram reconhecidos por entidades privadas nas cidades, como os bancos, que aceitavam uma declaração ou a carteirinha do MTR como comprovante de endereço para abrir uma conta, por exemplo. Nesse contexto, ter um documento "é prova de pertencimento a uma comunidade” (Peirano, 2002, p.55).

\section{Vale mais um dia de luta do que um mês de barraco}

O investimento ou busca de recursos durante as mobilizações aparece recorrentemente nos relatos de acampados e militantes: o quanto foi gasto, em dinheiro, em materiais comprados ou conseguidos por eles para fazer a mobilização acontecer, o esforço e o 
tempo dedicado à mobilização e as pessoas e o capital de relações que foram mobilizados. Assim como no caso das dificuldades, o fato de relatar, ou falar sobre os recursos, tanto para o militante como para o acampado, parece ser uma forma de legitimar, para eles mesmos e perante outros, seu tempo de luta.

Alguns acampados do acampamento Famílias Unidas, revoltados com a indicação de militantes e duas famílias do acampamento para uma vaga numa fazenda vizinha, isto é, para serem assentados, começaram a reavaliar e fazer um balanço dos recursos investidos no seu tempo de luta. Teresa, a quem já fizemos referência anteriormente, acampava fazia quase dois anos com seus dois filhos pequenos. Ela questionava os critérios da indicação das famílias. Para ela, algumas famílias estavam sendo vítimas de uma injustiça por parte dos militantes do MST do acampamento, pois a exigência de participação nas jornadas, como requisito para poder ganhar terra, não levava em conta a situação particular das famílias. Ela, com dois filhos pequenos, não podia participar de todas as jornadas, em compensação, ou mandava um representante da sua família ou pagava para que alguém a representasse dependendo do tipo de jornada. Sigaud (2000), Sigaud et al. (2002) e Loera (2006) identificaram, nos acampamentos da reforma agrária, a existência de representantes, geralmente parentes ou conhecidos que ficavam debaixo da lona guardando o lugar para um parente ou amigo. No entanto, segundo material recolhido em campo em acampamentos do noroeste do estado de São Paulo, não há somente representantes que estariam cumprindo tempo de barraco pelo parente ou amigo, mas haveria uma distinção entre representante e substituto para o caso de jornadas. Representante geralmente é alguém da família ou conhecido que vai participar no lugar do outro. Substituto é alguém geralmente desconhecido, que pode ser acampado, assentado ou qualquer outra pessoa que participará na jornada ocupando o lugar daquele que não vai participar.

Quirós (2006, p.78), na sua etnografia sobre os movimentos piqueteros em Buenos Aires, também identificou a existência de uma prática da substituição nas mobilizações e a importância dessa prática para a obtenção de recursos por parte do Estado: 
a generalidade da prática da substituição parece revelar, por um lado, a importância que a quantidade tem para os movimentos. Eles dependem dessa participação já que da quantidade mobilizada depende também a capacidade de negociação com o Estado. Por outro lado, as substituições dizem também a respeito da importância que a presença tem para as próprias pessoas que marcham. (Quirós, 2006, p.78, tradução minha) ${ }^{11}$

Como relatado por Teresa, nas assembleias era passada a informação das jornadas. Geralmente os acampados não ficam sabendo sobre o tipo de jornada que acontecerá até pouco antes do evento. Quando é uma ocupação, os acampados podem passar de quinze a vinte dias fora dos seus acampamentos e, como mencionava seu Joaquim, pai da Teresa, "para quem mora no acampamento, é difícil deixar barraco, filhos, parentes, criação sem ninguém durante esse tempo, por isso não vai todo mundo nas jornadas".

Teresa relatava que ela e seus pais, que moravam no barraco ao lado do seu, haviam encontrado uma maneira de estarem presentes na maioria das jornadas, isto é, "revezando a participação". Contudo, na última jornada que ela participou, a estratégia de revezamento não havia funcionado, pois o coordenador do grupo do MST não aceitou que só ela participasse e argumentou que ela e seus pais tinham dois cadastros no acampamento; então, ela poderia participar da jornada, mas teria que ter um substituto pela não participação dos pais. Esse fora um dos motivos que a levaram a mudar de movimento dentro do próprio acampamento e passar "para o grupo do Neguinho". ${ }^{12}$

11 "la generalidad de la práctica del reemplazo parece revelar, por un lado, la importancia que la cantidad tiene para los movimientos. Ellos dependen de esa participación, pues en la cantidad movilizada se juega la capacidad de negociación con el Estado. Por otro lado, los reemplazos hablan, también, de la importancia que la asistencia tiene para las propias personas que marchan."

12 Como vimos anteriormente, o grupo do Neguinho surgiu após o último racha acontecido no acampamento, no qual algumas famílias de acampados do MST passaram para o MTR (grupo do Nino) e outros criaram o grupo do Neguinho sob a bandeira do Sintraf. 
Dércio, também pela mesma razão apontada por Teresa, havia ido "para o lado do Nino". Dércio relatava que, por estar encostado, não podia participar de todas as jornadas organizadas pela militância do acampamento. ${ }^{13}$ No entanto, inúmeras vezes havia contribuído para as jornadas chamando um substituto durante vários dias, o tempo que demorasse uma nova família para se instalar debaixo da lona e ocupar o lugar daquele acampado temporário. Nesse caso, o "tempo" é um bem que pode ser acumulado, negociado e trocado e também faz parte dos recursos que podem ser mobilizados.

Seu Joaquim, Lucia, Teresa, Neusinha e Dércio, vizinhos de barraco no acampamento Famílias Unidas, participaram várias vezes de jornadas para abrir acampamento. Essa expressão é comum nos acampamentos de São Paulo e significa participar de uma ocupação que irá inaugurar um acampamento, ocupação que se diferencia de outras ocupações vapt-vupt, que geralmente já sabem que levarão a um despejo, cujo objetivo é mais do que formar um acampamento, é fazer um protesto e chamar a atenção a respeito de certas datas comemorativas ou de outras demandas, como pedir a liberação de áreas, já vistoriadas, liberação de créditos para assentamentos e outros. Existem, portanto, diferentes tipos de mobilizações e, dentre elas, diferentes tipos de ocupações.

Geralmente os acampados que participam de uma mobilização não são avisados com antecedência sobre o tempo que vai levar e, geralmente, tudo acontece sob um clima de segredo, mas, independentemente do tipo de mobilização, devem levar por conta própria o que alguns acampados em São Paulo chamam de kit sem-terra, e consiste basicamente em colchonete, coberta, colher, prato e xícara.

Em geral, velhos acampados se queixavam recorrentemente de terem que comprar ou levar por conta própria os materiais para

13 Estar encostado é uma expressão recorrente entre acampados, quando fazem referência a alguém que foi aposentado por doença, o que, nos termos oficiais do Estado, significa aposentadoria por invalidez, < http://www.previdenciasocial.gov.br/> Portanto, para os acampados, estar encostado ou estar encostado no INSS significa também estar recebendo benefícios do Estado, especificamente uma aposentadoria do Instituto Nacional do Seguro Social (INSS). 
participar de mobilizações. No caso de uma ocupação, a lona preta é sempre um dos itens em disputa. É um material que os acampados consideram fundamental para participar de uma ocupação e acreditam que o movimento que organiza a ocupação tem a obrigação de dar.

Como demonstrado em outro trabalho (Loera, 2006), nos acampamentos, a lona preta é um bem valorizado, é objeto de troca e de negociação entre acampados e inclusive, muitas vezes, é guardado como um tesouro, prevendo futuras ocupações. E, precisamente, por ser um bem de tanto valor nesse mundo social, quando não é dado pelo movimento e precisa ser comprado ou conseguido pelos acampados para ser usado durante uma mobilização, os recursos (dinheiro, tempo e relações) são considerados um investimento enorme.

O investimento de recursos geralmente é maior em uma ocupação de terra do que em uma marcha, passeata, ocupação de prédio público ou bloqueio de estrada. Com exceção das mobilizações que vão além dos limites estaduais e são consideradas nacionais, como exemplo, a Marcha Nacional dos Sem-Terra, ocorrida em 1997, que demandou um enorme investimento de recursos e mobilizou mais de 40 mil pessoas vindas de diversas regiões do Brasil; ${ }^{14}$ geralmente, nas ocupações organizadas em nível estadual e municipal, o deslocamento das pessoas requer um investimento maior em tempo e recursos materiais, assim como um capital de pessoas, de negociação e de relações por parte da militância pré e pós-evento do que qualquer outra mobilização.

No caso da ocupação que deu vida ao Dom Hélder Câmara, em Birigui (SP), não só teve um custo grande para o movimento deslocar mais de 50 famílias e seus pertences, a 600 quilômetros de distância, mas também teve uma dedicação importante de tempo para organizar as famílias do TSM que iam participar; assim como outros acampados, assentados, vereadores, pároco e outras autoridades que foram acionados para que a mobilização acontecesse.

14 Para uma descrição detalhada da Marcha Nacional dos Sem-Terra, ver Chaves (2000). 
Conforme me disse um militante do MST:

A luta não se faz sem recurso, está mentindo quem falar que dá para organizar uma luta sem recurso [...], o movimento quando dá, apoia, mas a gente tem que se virar, fazer as correrias e conseguir o recurso.

E é por meio desses recursos que se fazem visíveis as relações de interdependência no mundo das ocupações de terra, entre militantes dos movimentos, acampados, representantes de governo e lideranças locais das cidades próximas aos acampamentos.

Por outro lado, como vimos, o tempo de luta não necessariamente se alcança somente participando de mobilizações, o tempo de luta também se vivencia nas cidades, negociando e mobilizando recursos, em palavras nativas fazendo as correrias.

No mundo das ocupações de terra, os velhos acampados, como vimos no capítulo anterior, tornam-se fundamentais para mostrar ou ensinar aos novatos as regras e códigos desse mundo social. O relato cotidiano de experiências pode ser por vezes alentador e por vezes desanimador, mas sem dúvida é fundamental para a continuidade da luta.

Por ocasião da organização de uma marcha que sairia do acampamento Terra Sem Males, em uma reunião, dois novatos questionavam a exigência, por parte da militância do acampamento e dos militantes da Regional de Campinas, de ter que participar da marcha. Argumentavam que já era suficiente o sofrimento de ficar debaixo da lona. Zê Antônio, velho acampado e militante do acampamento, ${ }^{15}$ que escutava atento a conversa, interveio tentando

15 Devo especificar que os acampados percebem a militância do MST de distintas maneiras: por um lado, alguns acampados que de fato moram nos acampamentos, mas estão envolvidos nas tarefas locais do MST, podem ser considerados pelos acampados como militantes do acampamento. Por outro, há os militantes que visitam o acampamento, mas não ficam ou não moram com os acampados e geralmente fazem parte de alguma comissão ou núcleo do MST ligada à Secretaria Estadual ou Nacional, estes são considerados cabeças 
explicar para eles: "não adianta ficar só no barraco, sem se mexer"; segundo Zé Antônio, "a luta” implicava "ir para a rua”. Não bastava, para tanto, ficar no barraco, nas palavras dele: "não adianta ficar parado esperando que as coisas aconteçam, esses [acampados] que estão indo para a luta [na marcha], vão conseguir, esses são os que vão conseguir, o camarada que fica no seu barraquinho, só esperando que os outros façam, esse não vai...". Ainda, ele citou como exemplo uma família do acampamento que tinha cinco crianças, mas sempre participava da luta, segundo ele, "carregavam com as crianças e iam para a luta”. Zé Antônio parecia dar mais valor às famílias que de fato participavam das mobilizações que àquelas que, como mencionava um militante de Andradina, "driblam a luta".

Biro, militante do MST e coordenador do Famílias Unidas, fazia questão de repetir "vale mais um dia de luta do que um mês de barraco", quando alguém no acampamento questionava o fato de permitir a presença dos chamados moradores de final de semana ou apoios. Como vimos, os apoios são pessoas que não moram no acampamento e passam só alguns dias no acampamento ou inclusive só comparecem às assembleias ou a reuniões coletivas. Entretanto, a maioria desses apoios participa ativamente das jornadas. Para Biro, esses apoios são o "Bope das ocupações". A maioria deles sabe que só pode ganhar um pedaço de terra tendo tempo de luta, podem não ficar debaixo do barraco, todavia, sabem que devem cumprir com as jornadas.

Esse é o caso de Helena, Raleigh, Jonas, e as mais de sessenta famílias que eram apoios do acampamento Famílias Unidas. Criticados pelos moradores do acampamento precisamente por não

do movimento, aqueles que na percepção dos acampados ocupariam posições de destaque no movimento. Os primeiros, militantes dos acampamentos, como já foi mencionado no capítulo anterior, muitas vezes não são considerados dessa maneira pelos militantes das Regionais, e são vistos como apoios do acampamento. Alguns acampados classificam os militantes das Regionais como militantes de experiência. Barra (2007) os identifica como "militantes profissionais". Na percepção dos acampados, os militantes de experiência são os que teriam mais tempo de luta. Tempo que estaria mais relacionado com um saber particular, com um know-how do modo como funciona o mundo das ocupações de terra e menos com uma medida cronológica. 
morarem debaixo da lona, as famílias consideradas apoios eram para militantes do MST os participantes mais valorizados. ${ }^{16}$

Dona Helena, que em 2009 contava 55 anos, era considerada, por outros acampados do Famílias Unidas, e pelos militantes do MST de Castilho, uma das mais ativas participantes nas jornadas.

Dona Helena mencionava ter perdido a conta das jornadas que já fizera, a última delas havia sido um "evento de mulheres" organizado pelo MST. Dona Helena tinha menos tempo de barraco que outras famílias do acampamento, no entanto, tinha uma série de jornadas na contabilidade do seu tempo de luta.

Raleigh também era dos apoios do acampamento, morava em uma cidade próxima e, em meados de 2008, tinha chegado como novata ao acampamento Famílias Unidas. Era a primeira vez que fazia parte de um acampamento de sem-terra. Tal como Dona Helena, ela sabia da importância da participação nas jornadas para ser considerada pelos coordenadores do acampamento para um lote de terra, ${ }^{17}$ mas também para obter o que é chamado benefícios de acampado, entre eles, cesta básica, doações e a possibilidade de ter acesso a benefícios públicos do Estado, como o programa bolsa-família. ${ }^{18}$ Raleigh sabe que os apoios não são bem-vistos pelos moradores que argumentam que não passam pelas mesmas penúrias daqueles que ficam debaixo da lona. No entanto, Raleigh justificava: "pagamos com participação em jornadas”.

16 Em pesquisa realizada recentemente (2013) em acampamentos do estado de São Paulo, percebemos que os apoios, também conhecidos como andorinhas, são hoje em dia a população mais numerosa dos acampamentos, e como já foi comentado, são também fundamentais para sustentar esses espaços por meio de trocas de favores com os moradores, doações de cesta básica, ou de outros itens e também consumindo nas pequenas miscelâneas dos moradores instaladas nos acampamentos. Para um aprofundamento sobre essa problemática ver Loera, 2013.

17 Como será tratado no capítulo "Tempo de reforma”, os militantes e coordenadores dos acampamentos têm uma participação decisiva na indicação de pessoas para uma vaga ou um lote dentro de um assentamento.

18 Alguns acampados acreditam que o benefício do bolsa-família só pode ser adquirido por estarem acampando. 
Neusinha, também apoio do acampamento, cumpria regra de três dias e era também bastante ativa nas mobilizações, era uma pessoa de confiança do coordenador do MST. Ela levava inclusive o controle do caderno de pontos. Pessoas como Neusa, com tempo de luta, adquirem certo capital de confiança entre militantes, como também reconhecimento e prestígio, ganhando assim visibilidade entre os próprios acampados. Para o coordenador do MST, esses são os acampados que "mais valem", pois "não ficam só debaixo do barraco, vão à luta”.

Acampados do acampamento Famílias Unidas, em conversas cotidianas, costumavam comparar sua participação em jornadas. Dércio, que, numa discussão entre vizinhos, tentava colocar em destaque seu tempo de luta perante o argumento de alguns apoios, de terem muitos acampados que só ficavam debaixo da lona, mencionou que ele não participou fisicamente de muitas jornadas, mas, nas importantes, segundo ele, "naquelas obrigatórias", tinha ido. Portanto, parece que a participação efetiva numa jornada tem muito mais valor que aquela para a qual se leva um substituto.

Por outro lado, há também mobilizações que são consideradas mais importantes do que outras, geralmente aquelas que acontecem durante o abril vermelho ${ }^{19}$ e que acabam sendo mais espetaculares e agregam um número maior de pessoas, mobilizam mais acampados e a participação é mais cobrada. Existem, portanto, gradações nas mobilizações e níveis de participação.

A cobrança na participação em mobilizações também depende da estruturação do movimento. Um militante me explicava contando sobre uma ocupação realizada no Banco do Brasil de Ilha Solteira (SP), na qual alguns assentados e acampados da região participaram como parte de uma série de mobilizações:

foi uma ordem que veio da nacional, as ordens nacionais podem ser questionadas, mas devem ser cumpridas, quando há uma mobi-

19 Alusão ao que ficou conhecido como Massacre de Eldorado dos Carajás, no qual 21 trabalhadores rurais do Pará foram mortos pela Polícia Militar. Desde então o MST realiza mobilizações chamadas de "abril vermelho" (N. E.). 
lização que é mais local ainda se pode driblar a participação, mas não quando é uma ordem que vem da nacional. (Cido, dezembro de 2008)

Devo mencionar que, geralmente, nas mobilizações cuja participação se considera "obrigatória", são feitos acordos entre movimentos para mobilizar os acampados, independentemente do movimento que lidera ou organiza a mobilização, e deve ser chamado o maior número de acampados possíveis.

Esse foi o caso, por exemplo, da reocupação de uma fazenda na região do Pontal. Naquela ocasião, em novembro de 2006, militantes de vários movimentos e coordenadores de diversos acampamentos da região mobilizaram seus respectivos acampados para realizarem uma grande ocupação, na qual, como relata um dos militantes, "foi a melhor luta da região, com mais de 800 famílias".

No jornal Folha da Região, de Araçatuba, comenta-se sobre a mobilização e os movimentos que a organizaram:

A promessa dos sem-terra é continuar com a série de protestos até que o Judiciário ao menos marque as datas dos julgamentos das propriedades consideradas improdutivas. Segundo o MST, há 14 fazendas nessa situação na região e 1,5 mil famílias em 15 acampamentos às margens das estradas à espera de terra. A onda de protestos dos sem-terra começou na madrugada de domingo, com a invasão da fazenda Cafeeira, em Castilho. Desde então, os trabalhadores têm feito um protesto por dia. $\mathrm{Na}$ segunda-feira, foram feitas marcha e manifestações em frente à Câmara e a Prefeitura, também em Castilho. Na terça-feira, houve a ocupação do banco em Ilha Solteira. Os protestos são coordenados por integrantes do MST, do Sintraf (Sindicato dos Trabalhadores da Agricultura Familiar) e do Seran. (Sindicato dos Empregados Rurais $)^{20}$

20 "Sem-terra ocupam Banco do Brasil e Incra em Andradina", Folha da Região, Araçatuba, 17 de novembro de 2006. Disponível em: <http://www.folhadaregiao.com.br/noticia?59208>. Acesso em: 2 jun. 2009. 
Os acampados do acampamento Famílias Unidas relatavam que a ocupação acontecida em novembro de 2007 em uma fazenda da região também tinha sido uma ocupação importante, na qual a participação de todos os acampados foi cobrada. A jornada foi organizada em cooperação entre militantes do MST e membros do Sintraf e, naquela ocasião, a participação era obrigatória.

Biro, com orgulho, relatava que o acampamento Famílias Unidas havia estado representado em "todas as lutas do estado", ou seja, acampados desse acampamento haviam participado de todas as mobilizações organizadas pela militância estadual do MST. Para esse coordenador, era importante o acampamento "cumprir com um mínimo de lutas" e que os acampados, de maneira individual, também cumprissem "com um mínimo de jornadas".

Devo mencionar que, apesar de existir uma hierarquia ou estruturação dentro do MST, que faz que a militância das estaduais e regionais siga certas formas ou modelos preestabelecidos para operacionalizar ou organizar uma mobilização ou gerenciar um acampamento, existe também uma heterogeneidade nas formas de atuar da militância e certa autonomia. Autonomia esta que depende, no entanto, de uma série de relações de interdependência.

O caso da mobilização e posteriormente formação do acampamento Dom Hélder Câmara é significativo para exemplificar o argumento acima. Como foi mencionado anteriormente, esse acampamento foi constituído pelas cinquenta famílias vindas do TSM e por famílias de novos acampados convidados em trabalho de base. $\mathrm{Na}$ ocasião, como foi mencionado no capítulo anterior, haviam sido "transferidos" de uma regional dois militantes para coordenar o novo acampamento e criar outra regional.

No Dom Hélder, os acampados constantemente comparavam, sob uma lógica da diferenciação, o trabalho da militância de uma e outra regional, e era comum ouvir a frase: "aqui é outro movimento".

Efetivamente as pessoas envolvidas na militância, e encarregadas da coordenação do Dom Hélder, não eram as mesmas do TSM, apesar de "pertencerem" a um mesmo movimento. 
Macedo menciona que, apesar de existirem similitudes nas formas de organização dos acampamentos, também existem diferenças que "dependem das trajetórias pessoais dos militantes [e eu diria também dos desejos e das expectativas pessoais], dos perfis sociais de cada grupo acampado e do contexto específico no qual cada disputa fundiária está inserida" (2003, p.147). As pessoas responsáveis pelo Dom Hélder, com trajetórias, desejos e expectativas diferentes, não só não eram as mesmas responsáveis pelo TSM, como também a prioridade para a militância regional do movimento era outra que não a coordenação do acampamento, e sim consolidar um escritório regional do MST, começar a estabelecer relações com políticos locais, com a prefeitura e com representantes locais dos órgãos de governo. Portanto, o trabalho da militância se concentrava muito mais nas cidades próximas fazendo as correrias, do que no próprio acampamento. Por outro lado, para os coordenadores do Dom Hélder, nesse contexto, a conformação de uma "Regional do MST", mais do que se dedicar ao acampamento, apresentava-se como uma oportunidade de conseguir um capital social e simbólico. A dedicação ao movimento e à mobilização de recursos, ou, em palavras nativas, o tempo de luta mais do que o tempo de barraco tinha nesse contexto, para esses militantes, uma recompensa, uma retribuição: um nome e um cargo de responsabilidade no movimento.

\section{Os bons de luta}

Fazer trabalho de base, correr atrás da cesta, correr atrás de recurso, correr atrás da ocupação, enfim, as correrias nem sempre são tarefa simples, e nem todo mundo consegue fazer bem.

Como já mencionado, existem relações de concorrência dentro dos próprios movimentos e, nesse sentido, aqueles que desejam se destacar dentro do movimento devem demonstrar seu potencial nas correrias e, principalmente, na luta. 
Um militante da região do Pontal, quando questionado sobre a diferença da atuação e organização da militância de uma e outra regional com respeito ao desempenho na coordenação de acampamentos, justificava da seguinte maneira:

A Regional [...] só tem um acampamento, nós temos dezesseis, não é o mesmo cuidar de um só que cuidar de dezesseis, lógico que vai estar mais organizado, se só tem um para cuidar, [...] nós temos mais de 1.700 famílias acampadas na região. (janeiro de 2009)

Para esse militante, o importante na luta, mais do que a dedicação aos acampamentos, é o número de pessoas que se consegue mobilizar.

Já para Edesmaria, ao fazer referência à atuação dos militantes, a diferença do desempenho na luta recai no trabalho realizado nas correrias.

Ser militante é aquela coisa de, sei lá, de mandar, querer ser uma coisa que não é, é uma coisa muito esquisita, eles sabem as coisas, é assim, a militância que eu acho certa é que nem [militantes da Regional de Campinas]; elas estão lá em Campinas, elas corre atrás da cesta, elas corre atrás de recurso para os acampados, elas correm atrás da ocupação e elas tão na frente, elas tão lutando com o povo, isso é um militante, como dizem de frente de massa e [...] outro de... quê? Tem outras coisas que eles fala, né. Elas correm atrás de apoio, de Igreja, de sindicatos; essa sim, essa é uma militância que eu acho que todos deviam fazer isso. Agora, chegar no acampamento, encher de militante para ficar só comendo, dormindo e botando os outros para fazer as coisas, não acho justo. (Acampamento Dom Hélder Câmara, novembro de 2003)

Noé e Luzia, um casal de acampados, acreditavam que dentre os militantes havia aqueles que podiam ser considerados bons de luta e outros que não. Para eles, o que marcava essa distinção era preci- 
samente o bom desempenho nas correrias: "É nas correrias que o acampado se destaca e o militante desponta”.

A própria Edesmaria explicava:

Edes - É o seguinte, eles [os militantes] tira aquelas pessoas que mais destaca, entendeu; se você se destacar bem, então você tem uma chance de ser uma coordenadora, agente de saúde...

Nashieli - Mas como é se destacar?

Edes - Sei lá, sobre suas proezas, sobre você enfrentar o que vem; bom, era assim, porque eu sempre fui assim mais distinguida, nunca tive medo de nada, sempre respeitei as pessoas, mas medo, não.

Nashieli - E o que você faz para ser considerada destacada?

Edes - Assim, você vai lá [no acampamento], quando você chega, você vai em frente, você sabe conversar com eles [os acampados], você tá ali, procura carro, fazer qualquer coisa para tirar dali, correr atrás de alimentação, né, negociar com os políticos, todo isso é um destaque para você se tornar um líder. (Bom Jesus da Lapa (BA), abril de 2006)

Para Edesmaria, ter uma chance de ter um cargo de responsabilidade no acampamento ou no movimento não depende só das vontades individuais, das proezas, mas precisa ter alguém que as valorize, que as reconheça, nos termos de Edes, "eles tira aquelas pessoas que mais destaca”. Segundo Bergamo:

Crê-se no valor individual das pessoas, como se esse valor não necessitasse nenhum reconhecimento social. Esse valor individual, no entanto, só pode ser obtido quando diante de mecanismos sociais que lhe atribuam e lhe reconheçam o significado. (2007, p.210)

Biro, por exemplo, se envolveu com a militância depois da primeira ocupação que deu vida ao Famílias Unidas, em dezembro de 2003. Na ocasião ele começou a participar na estrutura, montando barracos, para ele, "é na ocupação que a pessoa desponta, e aparece 
aquela que não tem medo de aparecer”. Mencionou que naquela ocupação os militantes já estavam de olho nele. Hoje em dia, como ele me disse, "a família toda é do movimento". Sua esposa é dirigente regional do MST do Frente de Massa e sua filha faz faculdade de Direito em Goiânia, numa escola do movimento. Na percepção dele, "o movimento é igual a um morcego, chupa tudo de você e envolve você cada vez mais e mais". Ainda mencionou que existe uma diferença substantiva entre militar no movimento e só coordenar um acampamento, mesmo se tudo começa na ocupação e com a coordenação de um acampamento, para ele "acaba sendo como uma bola de neve, vai acumulando cada vez mais e mais e pedindo e demandando cada vez mais".

O caso de Rose é parecido com o de Biro. Estudante de Ciência Política de uma universidade paulista, Rose se envolveu com a militância do MST na ocasião da ocupação do TSM. Ela participou na organização daquela ocupação fazendo trabalho de base e conseguindo os recursos e acabou se destacando dentre outros participantes. Um mês depois, numa assembleia realizada no acampamento, por ocasião da visita de um grupo de universitários, lideranças do acampamento e do MST tornaram público seu reconhecimento. $\mathrm{Na}$ ocasião, um militante da Secretaria Estadual mencionara que em nome do MST agradecia o apoio de todos os estudantes e universitários que se interessavam com as causas do movimento, mas dessa vez devia agradecer especialmente a uma pessoa que se havia destacado por causa do seu desempenho e envolvimento na ocupação e formação do TSM, a Rose. Um tempo depois, Rose acabou desistindo dos seus estudos e se envolveu cada vez mais com as tarefas do movimento, inclusive encontrou um companheiro de vida também envolvido na militância do MST. Mais tarde passaria a fazer parte da Direção Nacional do MST.

Nesse mundo social, o fato de receber uma oferta por parte do movimento, nesse caso um cargo considerado de responsabilidade, faz as pessoas se sentirem levadas em conta, importantes, prestigiadas nesse contexto, contudo também parece iniciar, através de 
uma divida, uma série de trocas e obrigações para com o movimento. Aquele que aceita o cargo se sente endividado com aquele que fez a oferta e se sente comprometido para ficar e dedicar mais tempo às tarefas do acampamento e do movimento. Muitas vezes, alguns desses oferecimentos acontecem quando aquele que recebe a oferta se encontra numa situação de incerteza sobre ficar ou desistir da luta.

Edes, por exemplo, relata que na Bahia, seu estado de origem, ela nunca se instalou para "morar debaixo da lona". No começo acompanhou a sogra, que era acampada. Ela optou por passar mais tempo no acampamento no momento em que lhe ofereceram a coordenação de um acampamento novo; depois daquela oferta, ela começou a demorar mais para voltar para casa.

Ficava lá [no acampamento] oito dias; o que mais demorei no acampamento foi vinte dias, [quando] um acampamento novo surgiu e aí eu era a coordenadora geral do acampamento, me colocaram lá como coordenadora e aí eu tive que ficar. (Serra do Ramalho, abril de 2006)

E outro caso, o de Nora, que havia saído de Salvador para se juntar ao marido (envolvido com a militância do MST em São Paulo) e que em 2002 estava ajudando na organização do TSM. O objetivo de Nora era convencê-lo para que saísse do movimento. Nora começou a participar das tarefas do movimento junto dele até que recebeu a proposta de, com seu marido, ser coordenadora de acampamento.

Aquelas pessoas que são convidadas e aceitam fazer parte da militância também acabam contribuindo para o tempo de luta daquele que os convida. Assim sendo, a formação, no mundo dos movimentos, também é fundamental como capital simbólico.

O coordenador do acampamento Famílias Unidas sentia-se orgulhoso por ter conseguido mobilizar as pessoas do acampamento para participarem de todas as lutas da estadual, porém o mais importante, para ele, era que dali já "haviam surgido vários militantes para o movimento". 
Entretanto, devo especificar que nem toda pessoa que se destaca nas mobilizações desponta no MST.

Retomemos novamente o caso de Edesmaria. Na Bahia, por problemas pessoais e de relacionamento com seu marido, acabou se afastando das atividades do movimento e só depois, quando acampou no TSM, voltou a fazer o que ela gostava: trabalhar no acampamento. No entanto, seu desejo de trabalhar para o movimento não encontrou eco entre a militância do TSM e da Regional de Campinas, onde as tarefas realizadas para o movimento se limitavam ao acampamento.

Edes, estando no TSM, chegou a coordenar grupos e setores dentro do acampamento, sentia-se útil por ter sob sua responsabilidade certos grupos de pessoas e porque essas pessoas e inclusive militantes costumavam descrevê-la como pessoa de luta. Todavia, para ela, seu tempo de acampamento não era reconhecido pelo movimento. Percebeu, por um lado, que o investimento em atividades do movimento, ou o que ela chamava de trabalho no acampamento, dificilmente conjugava com o trabalho físico, na roça, e, portanto, com a possibilidade de ser assentada; e, por outro, também percebeu que a idade era um fator que poderia dificultar sua vontade de trabalhar para o movimento, já que, na percepção dela, "no MST são os jovens os que crescem no movimento".

O desejo de significação social de Edes teve recepção não no MST, mas num pequeno movimento como o MTR. A experiência prévia de Edes em acampamentos do MST e o saber adquirido sobre o mundo das ocupações fizeram que seu tempo de acampamento fosse valorizado no contexto de um movimento relativamente novo e de alcance local.

Edes se destacou rapidamente dentre o grupo de acampados do MTR principalmente pela sua disposição e desempenho nas correrias. E provavelmente o fato de ter conseguido fundar um acampamento, como descrito no capítulo anterior, também lhe conferia um diferencial diante de outros acampados. Ela começou a ser percebida pelo coordenador do MTR como uma pessoa fundamental para conseguir os apoios. Esses apoios não só estavam relacionados 
com a obtenção de recursos materiais, como arrecadação de alimentos, água, doações, mas também com a capacidade de negociar, de estabelecer certas relações. Assim, Edesmaria começou a assumir tarefas que ela considerava de grande responsabilidade: ir à reunião com o prefeito da cidade, participar de reuniões com autoridades locais, organizar reuniões no acampamento. Ela se sentiu reconhecida, mesmo que o reconhecimento do seu bom desempenho nessas tarefas dependesse de outros acampados e principalmente dos coordenadores do movimento.

Rosa (2011), em seu trabalho $O$ engenho dos movimentos, mostra como entre os grupos da Federação de Trabalhadores da Agricultura de Pernambuco (Fetape), que realizam ocupações, a juventude é ligada à demanda por reforma agrária. E ainda, segundo esse autor, são os jovens os que mais se identificam com os métodos e as formas de ação do MST, porém, a meu ver, os dirigentes dessa organização (das regionais e estaduais) também preferem formar quadros de jovens, por acreditarem que têm uma maior liberdade de ação. Alguns autores (Guaraná, 2006; Silva, 2006) mostraram que em contextos rurais, a categoria "jovem" adquire diversos significados e geralmente essas diferenças podem passar por distinções de gênero e pelas posições que os indivíduos ocupam na hierarquia familiar. Já para Silva, os homens deixam de ser jovens e passam para a idade "adulta" quando casam e começam uma vida com uma companheira. Para Guaraná, a categoria “jovem” em acampamentos e assentamentos rurais está fortemente marcada pelo lugar que se ocupa na hierarquia familiar e adquire diferentes significados que variam de acordo com os espaços de sociabilidade nos quais se circula.

Segundo Smircic, as possibilidades oferecidas por um movimento como o MST são mais aproveitadas pelos jovens, por causa do momento da vida em que se encontram, "em geral, estão sem famílias (de procriação), o que facilita a circulação, os deslocamentos" (2000, p.22).

Em campo, pude constatar que entre militantes do MST circula uma crença de que os jovens, por não terem compromissos familiares, se arriscam mais e, portanto, podem cumprir e se comprometer 
mais nas tarefas do movimento. De fato, uma militante com pouco mais de 30 anos de idade e mãe de duas crianças se queixava do fato de ser tratada pelos dirigentes da Regional como se fosse "qualquer jovem do movimento, como se não tivesse família”, já que lhe eram atribuídas tarefas que implicavam dedicação integral, inclusive durante os finais de semana.

Destarte, no mundo das ocupações de terra, a chance de ser reconhecido depende daqueles que já têm um lugar nele e depende do lugar que ocupam. E, mais, depende da reunião dessas vontades num contexto e em circunstâncias sociais determinadas.

Nos acampamentos organizados por militantes do MST, aqueles acampados que vão à luta se destacam do restante e são considerados como bons acampados, tornando-se um bem valorizado dentro do mundo das ocupações de terra, inclusive, muitas vezes, podem ser objeto de disputa.

Zé Antônio, do TSM, explicava que, em janeiro de 2003, havia chegado ao acampamento um grupo de novos acampados, fruto do trabalho de base dele. A maioria eram homens sozinhos, que se haviam instalado dentro de um barracão coletivo. Esse grupo, logo nos primeiros dias da sua chegada, havia sido rotulado por outros acampados e militantes como o grupo dos encrenqueiros e nenhum outro militante havia querido trabalhar com eles. ${ }^{21}$ Segundo Zé Antônio, em poucos meses ele havia feito um bom "trabalho de base dentro do barracão", ou seja, um trabalho de convencimento para que os homens do barracão começassem a se envolver no trabalho e nas tarefas coletivas dentro do acampamento e nas mobilizações organizadas pelo movimento.

Zé Antônio, orgulhoso, relatava:

O pessoal que tava no barracão foi trabalho de base meu... Eu continuava fazendo trabalho de base dentro do barracão com eles,

21 Alguns militantes e apoios do movimento realizam o que eles chamam trabalho no acampamento, isto é passar os ensinamentos do MST, as regras do acampamento e fazer um trabalho de convencimento para que as famílias fiquem no acampamento. 
né, eu ficava lá martelando, conversando, explicando por que deve ser assim para isso dar certo, o problema nosso [da militância] que é, nós trazemos a família, organizamos mais a militância dentro do acampamento, ela se restringe ao barraco ou a reunião não ao convívio dentro do acampamento e isso daí é o que não dá muito certo, tem que fazer um convívio, porque, por exemplo, esse grupo aí era o grupo mais encrenqueiro, era famoso, aí me tiraram lá para tomar conta aqui, virou uma bênção. (Acampamento TSM, abril de 2003)

Segundo ele, havia inclusive outros militantes querendo levar alguns do barracão para o trabalho de formação. ${ }^{22}$ Zé Antônio deixava entrever a existência de concorrência e disputa pelos bons acampados, mas também que a reputação do bom acampado, de alguma forma, também alcança aquele que fez o convite para acampar ou que se sente responsável por aquele acampado, pois os acampados são associados com o nome de quem realiza o convite para ocupar ou para fazer parte de um acampamento já montado. E, de alguma forma, o bom acampado é também apropriado e parte fundamental do capital simbólico do militante.

Segundo um militante do MST, o bom acampado é aquele que cumpre com três condições básicas:

1) "ser boa gente", o que significa não dar problemas, não se meter em encrenca e cumprir com as regras do acampamento;

2) "participar da luta", ou seja, participar das jornadas;

3) "morar no acampamento".

Aquele que só cumpre com uma ou duas dessas condições não preenche os requisitos de bom acampado; no entanto, para alguns militantes, a segunda condição acaba tendo mais importância do que as outras, já que, como foi mencionado anteriormente, afinal é a participação nas lutas e, principalmente, as novas ocupações

22 Isso significa convidá-los para que assistam a cursos de formação do movimento; com esse convite, abre-se a possibilidade de que possam vir a se tornar militantes do MST. 
que irão garantir a continuidade do mundo dos movimentos e das ocupações de terra.

Neusinha, de quem já falei anteriormente, apesar de não ser moradora no acampamento, era considerada pela militância do MST do acampamento Famílias Unidas parte do grupo dos bons acampados. Por isso, o último racha acontecido no acampamento, no qual alguns apoios, entre eles Neusinha, saíram do grupo do MST para formar parte do grupo do Sintraf, decepcionou e desanimou o coordenador do grupo do MST. Segundo ele, esse "racha não só debilita ainda mais o acampamento, mas quebra a luta", já que "essas pessoas que participavam ativamente [das jornadas], passando para outro grupo, não se sentem mais na obrigação de participar de jornada nenhuma". Para Biro, com o racha no acampamento, o movimento perdeu pessoas valiosas que cumpriam com as obrigações de participar das lutas.

A cobrança por parte da militância na participação mobilizações depende das necessidades de cada Regional, mas também das particularidades dos acampamentos, do envolvimento do militante que participa da organização da mobilização e da percepção que ele tem da luta.

Ainda que, para os militantes do MST, os novos acampados cheguem a ser mais valorizados na hora de uma mobilização, aqueles com tempo de luta, experientes na arte das mobilizações, em geral, podem ser mobilizados segundo as necessidades do próprio movimento e, mais, são principalmente esses acampados os que geralmente cumprindo com suas obrigações conseguem mobilizar outras pessoas, e assim entretêm a espiral das ocupações de terra.

Nas palavras de Zé Antônio, o objetivo do movimento deve ser: "preservar os que tão, conservar eles com a mentalidade, mais, para o companheirismo, e esses dez que conseguir ficar aqui, eles podem trazer quarenta".

Devo mencionar que o militante e, inclusive, o acampado podem ser reconhecidos não só pelo número de pessoas que conseguem levar para a luta, mas também pela qualidade de pessoas que se leva e se consegue manter nos acampamentos. No caso dos 
militantes, também aqueles que fazem um bom trabalho nas correrias, protegem e se responsabilizam pelos acampados são os considerados como bons de luta. Já, no caso dos acampados, aqueles que dedicam tempo à luta têm iniciativa para propor novas atividades e sempre se mostram dispostos a participar em qualquer atividade do movimento, cumprem com todas as obrigações de acampado obrigações estas que dependem das regras de cada acampamento, contudo, em geral, a participação nas mobilizações é uma tarefa fundamental -, os que ficam acampados e não dão problemas são aqueles que serão reconhecidos como bons elementos ou bons de luta.

Em alguns acampamentos, famílias que infringem as regras do acampamento são toleradas, porém aquele que não participa das lutas tem menos chance de chegar a ser indicado, se surgir uma vaga numa fazenda. Para Biro, os acampados mortos, ou seja, aqueles que não vão à luta, "não merecem ganhar terra". Segundo ele, "o que forma as pessoas dentro da luta é a própria luta”. Para ele, o tempo de acampamento tem uma função, que é "criação e consolidação de grupos, participantes na luta”. Segundo ele, "esse é um objetivo que, com o acampado morto, é difícil conseguir". Militantes do MST pretendiam atingir esse objetivo com a nova estrutura do movimento: a criação do Frente de Assentamentos. Militantes e acampados são escolhidos a dedo ou indicados para serem assentados, dependendo do seu tempo de acampamento ou, como disse um militante da Coordenação Estadual do MST, "dependendo da luta que fizeram”, e são estes, os indicados, os que, na visão de militantes do MST, irão dar continuidade à luta a partir dos assentamentos. 


\section{3 \\ TEMPO DE REFORMA}

\section{Os indicados}

Em meados de 2005, a família dos Reis se encontrava morando em um barraco de madeira que havia montado num terreno vazio na periferia de Castilho, uma pequena cidade do interior de São Paulo, quando foi convidada para acampar novamente. Fazia mais de oito meses que a família tinha desistido do acampamento. Seu Alfredo havia conseguido trocar uma carroça e uma égua por um carro usado, com ele, seus filhos Tiago e Marcos iam fazer bicos na cidade de Andradina, principalmente fazendo serviço de pintura de casas. Cleusa fazia alguns meses que trabalhava como doméstica, realizando faxinas três vezes por semana e cobrando 20 reais a diária. Cleusa queixava-se continuamente do pouco que se pagava nessa cidade pelo serviço de casa. Quando ela trabalhava em Sumaré, "o mínimo que cobrava era 50 reais". Alfredo continuava recebendo sua aposentadoria, mas, mesmo juntando o dinheiro que ambos ganhavam por mês, para eles era difícil sustentar uma casa com dois filhos e ajudar também a família de Tiago, o filho mais velho, que já tinha dois filhos e não tinha um emprego fixo.

Em 2002, quando o casal estava acampado no Terra Sem Males, tinha conseguido vender a casa de Sumaré por 2 mil reais e usado 
esse dinheiro durante pouco mais de um ano para se sustentar no acampamento. O dinheiro da casa havia terminado quando eles estavam no acampamento Dom Hélder Câmara e quase na mesma época a conta do banco pela qual seu Alfredo recebia sua aposentadoria havia sido bloqueada. Naquela ocasião, finais de 2003, a família toda, inclusive o filho mais novo, teve que trabalhar na fazenda próxima ao acampamento catando tomate, pois, como Cleusa me dissera, "estavam passando fome". Foi nesse contexto que a convite de Cláudio, um sindicalista da região vinculado à CUT, a família mudou para um acampamento montado na Fazenda Cafeeira no município de Castilho, com a promessa de que eles seriam assentados. Como já tinha acontecido anteriormente, ao experimentarem sucessivas mudanças de acampamento, sentiram-se traídos e enganados pelo sindicalista, pois, na percepção deles, os havia usado para movimentar, isto é, para fazer número na ocupação e abrir um acampamento, o acampamento do Cláudio.

Cleusa me relatava o reclamo que ela fez ao Cláudio, ao saber que teriam que participar de mais uma ocupação sem ter ainda perspectivas de serem assentados:

Você [Cláudio] trouxe nós lá de Birigui em cima da mentira, da cachorrada que vocês fizeram e você pôs nós na beira da estrada, falando que nós ia ser assentado e pôs nós na beira da pista, na beira daquela pista ali arriscando a vida. Agora você quer que [...]. Daí eu não saio para ocupação nenhuma. A partir de hoje, você não conta com a minha família para ir ajudar em acampamento nenhum, porque nós não vai, eu só saio dali só se for para a cidade ou para outro acampamento, mas nós fazer ocupação, nós não faz mais não; você pega sua família e você leva porque a minha família não vai. Ele falou: "Então vocês ficam de vigia". E eu falei: "Nem de vigia nós fica, ali não precisa de vigia, vigiar o quê, cada um que leve seu barraco nas costas". (Cleusa, assentamento Macali, dezembro de 2008)

É comum que entre os acampados, por ocasião de uma ocupação, sejam feitas acusações contra os militantes ou dirigentes que 
a organizam. Muitos acampados, principalmente inexperientes na arte de acampar, geralmente vão para um acampamento com a expectativa de que não terão que mudar mais e serão assentados. Quando isso não acontece, gera frustração e decepção e inclusive é comum que depois da mobilização alguns acampados acabem desistindo dos acampamentos. ${ }^{1}$

Noé, por exemplo, um acampado do Dom Hélder, me relatou que faltou pouco para ele desistir quando participou da saga de ocupações que culminou na formação desse acampamento. Ele nunca havia acampado e tinha saído de Campinas com o contingente de acampados do Terra Sem Males, com a promessa de que seriam assentados em Araçatuba. Segundo ele, só não desistiu porque não tinha como pagar as despesas de uma viagem de volta para Campinas com tudo e mudança. Noé se sentiu enganado e acusava aos militantes:

Mentirosa foi aquela militante que foi a que trouxe nós para Araçatuba. Falaram: "Vai sair uma fazenda lá na região de Andradina". "Mas saiu mesmo?" [ele perguntou], "saiu" [responderam]. Aí um colega meu que foi comigo, que voltou também, ficou sabendo e disse: "Eu vou também com você". Aí nós veio, arrumamos a bagagem, embarquemos naquela praça lá né, em Campinas. Ligamos lá na Secretaria [do MST] e falaram: "Você fica ali e espera que vão sair os ônibus lá da praça”. (Noé, acampamento Dom Hélder, novembro de 2003)

Os participantes das ocupações de terra, principalmente novatos, mencionam que prefeririam saber, desde o começo, que há ocupações nas quais devem participar por obrigação - mesmo sem

1 Brennesein (2003) e Loera (2009) identificaram, entre os trabalhadores do assentamento e do acampamento por elas estudados, acusações de engano e de traição. Em ambos os casos, o contexto era uma disputa pela imposição de projetos por parte de militantes do MST de um modelo de plantio coletivizado. 
concordar -, do que irem enganados para uma ocupação e com falsas esperanças de que irão fixar-se nas terras.

A decepção sofrida por Cleusa e Alfredo com a ocupação da Cafeeira é compreensível, se pensarmos que o desejo de conseguir um pedaço de terra representa muito mais do que simplesmente o desejo de ter um lote de terra para morar e trabalhar, representa, sobretudo, a possibilidade do recomeço, de reconstruir a vida. Nas palavras de Brenneisen (2003, p.58):

Se a busca da sobrevivência, através de uma diversidade de ações, envolve e mobiliza as famílias no tempo do acampamento, a esperança de, num futuro não muito longínquo, poderem reconstruir suas vidas, naquela nova terra, torna-se um elemento mais mobilizador ainda. É essa esperança e antevisão de futuro que possibilita a resistência dos agricultores sem-terra às agruras sofridas no tempo do acampamento.

Para Cleusa e Alfredo, o desejo frustrado de serem assentados, o sentimento de perda de confiança e de perspectiva e as dificuldades econômicas criaram um clima de desespero entre os membros da família, e foi nessa conjuntura que decidiram sair do acampamento e tentar a sorte na cidade mais próxima, Castilho. Foi também nesse momento que começaram a acumular algumas dívidas, principalmente com parentes de Sumaré e no banco, por causa de um empréstimo que pediram. ${ }^{2}$ Foi também que nesse contexto de dívida e de incerteza que Alfredo decidiu voltar a acampar. Seu Alfredo havia se encontrado com Afonso, na cidade de Castilho, um dos ex-coordenadores do acampamento Cafeeira. Afonso estava à frente de um novo acampamento montado na Fazenda Capim, nas proximidades de Castilho, dessa vez não mais sob a bandeira do sindicato, mas do MST. Esse dirigente reconhecia no seu Alfredo

2 Seu Alfredo pediu ao Banco do Brasil um empréstimo de 50 reais, que, com os juros, acabou acumulando uma dívida de 600 reais. 
e na sua família uma boa família, isto é, pessoas que não criavam problemas nos acampamentos e que cumpriam, como eles me relataram, "todas as obrigações [de acampado] direitinho". ${ }^{3}$ Assim ele convidou Alfredo para acampar novamente, mas, dessa vez, para que instalasse um barraco na Fazenda Capim. ${ }^{4}$

Alguns dias depois daquele encontro, Alfredo foi montar sua barraca no acampamento. Cleusa não quis ir junto. Segundo ela, estava com medo de ter que mudar de novo, deixar a vida na cidade, e que mais uma vez fossem ir somente para movimentar. Assim Cleusa ficou em Castilho, e Alfredo durante cinco meses ficou indo e voltando para o acampamento, de três a quatro vezes por semana. Cleusa às vezes o acompanhava e voltava no dia seguinte, levava o almoço e a janta pronta, pois no acampamento "não tinha nada, só o barraco". Segundo ela, "o Capim era acampamento fantasma, só tinha doze pessoas morando nos barracos, o resto era tudo apoio".

Cleusa mencionava que, mesmo sendo "um acampamento fantasma" e não tendo "nem estrutura nem organização nenhuma", preferia acampar em um acampamento do MST a se instalar em um do sindicato. ${ }^{5}$ Ela mencionava que, mesmo com algumas ressalvas, "os acampamentos do MST eram melhores porque um dia ou outro, com certeza, as terras saem”. Na percepção dela, "acampamento da CUT não anda" e ainda completou: "Você já viu algum

3 A família dos Reis, com outras famílias, ganharam notoriedade entre acampados e militantes do TSM e do Dom Hélder precisamente por cumprirem com os requisitos de um bom acampado, como foi tratado no capítulo anterior. Em conversas com militantes do MST da Regional de Campinas, fazia-se referência a essa família como um exemplo.

4 Ver a trajetória da família Reis em "Anexos", mapa 2.

5 A estrutura, para os acampados que já passaram por acampamentos organizados pelo MST, significa todos os espaços coletivos do acampamento: barracão de reuniões, escola, cozinha coletiva, secretaria etc. E a organização se refere às tarefas coletivas levadas a cabo pelos acampados em acampamentos do MST e à disciplina, que significa o cumprimento das tarefas e de outras obrigações de acampado. 
assentamento da CUT?". Para ela, a eficácia da "forma acampamento" está vinculada ao MST. ${ }^{6}$

Em outubro desse mesmo ano (2005), Alfredo e mais duas famílias de acampados da Capim foram indicados pela militância do MST para uma vaga na Fazenda Macali.

Na beira da fazenda, na estrada, estava montado um acampamento ocupado por antigos moradores do local, por famílias de novos acampados da região e por um grupo de acampados do Dom Hélder Câmara, que até abril de 2005 estava instalado em Birigui, na região de Araçatuba. Esse último grupo de acampados era o mesmo com o qual a família Reis havia convivido no Dom Hélder, e, de fato, muitos deles eram conhecidos de longa data, pois haviam estado com eles desde a época do Terra Sem Males. ${ }^{7}$

Luiz, um militante do MST, havia escolhido três velhos de acampamento do Capim para que fossem assentados na Macali.

Alfredo relata como foi essa escolha:

Quando o Luiz foi lá na Capim, o meu nome já tava lá na lista do Pontal [de um assentamento novo no Pontal], mas só que lá ninguém conhecia nós. Eles têm uma lista para eles assentar as pessoas mais velhas de acampamento, de tempo de acampamento. (Assentamento Macali, julho de 2006).

\section{E Cleusa completou:}

6 Feix (2001) se pergunta quais os motivos que levaram os assentados por ele estudados a participar dos acampamentos de sem-terra organizados por esse movimento e conclui que um dos principais motivos é a confiança no MST, que significava uma certeza de conquistar um pedaço de terra e de melhorar as condições de vida.

7 Dados recentes de campo mostram que as famílias passam por no mínimo quatro ou cinco acampamentos dentro das fronteiras estaduais, antes de serem assentadas, e alguns acampados acabam se reencontrando nesse percurso novamente com companheiros com os quais conviveram em outros acampamentos meses ou anos atrás, sinal de que há uma intensa circulação de acampados entre acampamentos. 
Os militantes, o pessoal mais forte lá de dentro [do movimento], eles têm essa lista para passar nos acampamentos, para pedir opinião dos acampados. Porque no caso, se for família ruim, bagunceira, baderneira, eles não aceita. Igual a Darlene e o Mário. Era para ser assentados aqui, a lista veio com o nome deles para eles serem assentados aqui, mas ninguém quis. É assim [a lista] é passado pelo acampamento primeiro e aí [os acampados que irão ser assentados] aceita ou não. Todo mundo que veio de lá [de Birigui] falou assim: "Esses daí [Cleusa e Alfredo] é para vim. Esses aí já têm tempo de acampamento, eles estão com nós desde lá de Atibaia, são famílias que nunca deu problema, têm filhos que nunca deram problema em acampamento". Aí todo mundo, quando cheguemos aqui, reconheceu nós. (Cleusa, assentamento Macali, julho de 2006)

Cleusa no seu depoimento deixa evidente, de uma ou outra forma, que no mundo das ocupações de terra como em qualquer outro mundo social, as pessoas estão indiscutivelmente ligadas entre si, existe uma rede de relações e, ainda que as pessoas circulem bastante por diversos acampamentos, de alguma forma, se mantêm ligadas. Foi o grupo de acampados do Dom Hélder, que acampava na beira da Fazenda Macali, que, olhando a lista levada por um militante do MST, reconheceu Alfredo e Cleusa na lista, e os aceitou de volta. Assim, esses assentados potenciais não só identificaram e reconheceram pessoas da lista, mas reconheceram famílias, a tal ponto de julgar se as pessoas da lista eram boas para assentar, como me disse Cida, uma assentada.

Comerford (2003), no seu estudo sobre famílias ligadas a sindicatos rurais na Zona da Mata Mineira, menciona que o sindicato é visto e vivido como objeto de disputas em torno da respeitabilidade e reputação. As famílias por ele estudadas estariam ligadas entre si através de formas de sociabilidade agonísticas, isto é, a provocação em todos os níveis de sociabilidade e em todas as situações, ou o que o autor identifica como uma política e poética das reputações. $\mathrm{O}$ autor, por meio da análise de narrativas em diversas situações, 
mostra que existem critérios de hierarquização das famílias, "as que contam" e as que "não contam". Segundo o autor, essa hierarquização está associada "a critérios como antiguidade no local [...], grau de união, boa reputação (o bom nome, as características positivas extraordinárias), e à capacidade de mandar" (2003, p.61). No depoimento de Cleusa antes citado, é evidente a importância que teve o tempo de acampamento como critério para serem escolhidos para uma vaga na Macali, mas também a importância desse tempo no reconhecimento da boa reputação da família, de serem considerados como uma boa família, como uma família que nunca deu problema em acampamento.

Como assinalado por Caume (2002), o Incra, a partir de 1998, definiu uma normatização mais precisa da metodologia de seleção dos candidatos potenciais à reforma agrária. Nessa resolução normativa, a identificação dos candidatos é realizada "a partir de listas previamente elaboradas nos "sindicatos de trabalhadores rurais, nos movimentos sociais de trabalhadores, nos órgãos de extensão rural do município ou em outras entidades" (Caume, 2002, p.44). Segundo o autor, nesse processo são solicitadas uma série de informações a respeito dos candidatos e são estabelecidos, a partir desses dados, "critérios eliminatórios" e "critérios classificatórios", para estabelecer "os melhores candidatos para assentamento" (2002, p.45). ${ }^{8}$

Como já foi mencionado, acampados, assentados e dirigentes dos movimentos percebem os participantes dos acampamentos como boas famílias ou bons acampados e aos assentados potenciais como bons para assentar. Como mostrado ao longo dos capítulos anteriores, há indícios de que essa percepção também vai sendo adquirida durante o tempo de acampamento. Loera (2009) mostra

8 "São considerados como eliminados aqueles candidatos com idade entre 16 e 21 anos, servidores públicos, com renda familiar não-agrícola superior a três salários mínimos, sócios ou proprietários de atividades comerciais ou industriais, agricultores proprietários de área de terra igual ou superior a um módulo rural, ex-beneficiários de projetos de assentamento oficial, deficientes físicos ou mentais, estrangeiros não naturalizados e aqueles possuidores de antecedentes criminais" (Caume, 2002, p.45). 
que os acampamentos do MST funcionam, nesse sentido, como uma espécie de peneira de "maus elementos", e acordos e relações entre movimento e as instâncias encarregadas da implementação das políticas de reforma agrária são traduzidos como disciplina, que de alguma forma prepara os indivíduos para se relacionarem com o Estado. No entanto, ainda resta saber se a política da indicação e seus critérios por parte dos movimentos e a percepção que os próprios participantes dos acampamentos e assentados têm de alguém "bom para ser assentado" está relacionada com os critérios do Incra, anteriormente mencionados, em outras palavras, se de alguma forma essa percepção teria sido forjada também na relação com o Incra.

Luzia e Noé eram um dos casais acampados do Dom Hélder, que conheciam Alfredo e Cleusa da Araçá, uma das fazendas ocupadas pelos acampados do TSM durante a saga de ocupações que precedeu à formação do Dom Hélder. Luzia me relatava o momento em que um militante [do MST] chegou ao acampamento Dom Hélder e mencionou que tinha encontrado seu Alfredo passando dificuldade, eles e o grupo de famílias de acampados que já o conheciam aceitaram logo seu Alfredo de volta. Ela relata aquele episódio da seguinte maneira:

Ele [o militante] chegou até chorar na reunião, eles vieram e falou: "Olha, eu tive passando em tal lugar e lá, eu falei: "Quem sabe eu não vou ver seu Alfredo por aqui e eu vi seu Alfredo”. E disse que foi para casa do seu Alfredo lá [em Castilho] e diz que via lá as estrelas [referência à precariedade da cobertura do seu barraco], que estava passando dificuldade. Ele falou: "Eu por mim, eu trazia ele [Alfredo] agora, mas eu só posso trazer ele, se vocês aceitarem". Aí o povo falou: "Quem que não quer, para reforçar nós? Nós traz ele”. Aí o movimento já faz aquela lista lá dos indicados. (Luzia, assentamento Macali, dezembro de 2008)

Assim, no final de 2005, depois de três meses de espera, a família Reis, com outras famílias de indicados, se juntou ao grupo de 
famílias do Dom Hélder, que estava acampado na beira da Fazenda Macali. ${ }^{9}$

Alfredo e Cleusa relatam com orgulho que foram os primeiros a entrarem na fazenda e a escolher um lote. Isso apesar do desacordo de alguns acampados, principalmente dos antigos moradores da fazenda e famílias originárias da cidade vizinha, que estavam acampando no local e que não os conheciam. Esses acampados não concordaram com o fato da militância do MST ter dado vagas no assentamento aos recém-chegados, que na perspectiva deles não tinham tempo de acampamento.

Deixemos Cleusa relatar os detalhes da indicação, a mudança de Castilho até a Fazenda Macali, o reencontro com os velhos conhecidos acampados do Dom Hélder, a entrada nas terras e a reação de alguns acampados:

O Alfredo chegou [em Castilho] e falou: "Arruma tudo aí que nós vai embora". Falei: "Nós vai embora para onde?" [...] "Mas que história é essa, Fredo, de nós ir embora [...]? Nós vai para lá, que nós lá já vai ser assentado. Mas como que nós vai ser assentado?” O Luiz veio lá no acampamento e escolheu três famílias, para levar para ser assentado lá [...]. Falei: "Vai cair nessa conversa". Ali ele falou: "Não estou brincando, foi escolhido o Rua, o Paraíba e o Zé Cabral, foi escolhido os três, só que o Zé Cabral ficou para decidir, vai dar resposta até amanhã. Ali vai depender do Zé Cabral, se ele não for nós vamos [...]. Lá estão só esperando o juiz dar decisão". Aí fiquei trabalhando. Aí, quando foi o sábado, aí a mulher do seu Zé veio. [...] Aí chegou o filho do seu Afonso e disse: "Seu Alfredo, meu pai mandou buscar o documento do senhor e da dona Cleusa, para fazer o cadastro e levar lá para o Luiz". Esse daí já ficou doido, aí catou os documentos e já foi lá para o seu Afonso, pediram para tirar o atestado de antecedência [...]. Daí encontrei o Luiz no posto

9 Sigaud et al. (2002) identificaram o uso do termo "escolhidos", na Zona da Mata de Pernambuco, para falar daqueles que conseguiram um lote de terra após terem ficado em acampamentos de sem-terra. 
de saúde, tava na correria, tinha vindo pegar um medicamento para uma pessoa que estava no acampamento. Aí eu perguntei: "E aí, Luiz, como que tá? Vai assentar mesmo?" Ele falou: "É certeza mesmo". [...] O Luiz falou: "Vocês ficam ligando na Secretaria [do MST], para dar informação como que tá o movimento lá em Pereira". Aí, quando foi um dia, eu liguei e ele falou assim: "Já tá tudo certo que até o dia 30 o juiz vai liberar as terras, aí nos avisa que é para vocês irem um dia antes". Aí passou dois dias e Afonso [coordenador da Capim] foi para reunião em São Paulo, para ver essas coisas e dar entrada na fazenda e essas coisas. Aí eram 3 horas da tarde e chegou a Maria [esposa dele] e disse: "Seu Alfredo, o Afonso ligou agora nesse instante de São Paulo e falou que é para vocês arrumar mudança logo, que depois de amanhã vocês têm que tá lá [na Macali], no dia 30 de outubro. Esse daí [Alfredo] já endoidô para querer derrubar a casa, e nós ia dormir aonde? Até aí não acreditei não, não acreditei [...].

Aí o caminhão veio no outro dia para carregar. Para dormir já carregado, para sair de madrugada. Nós viemos com a Brasília [carro deles]. Era oito e meia, quando chegamos aqui [na Macali], no dia da posse. Aí já demos de cara com Betinho, lá de Birigui [do Dom Hélder]. Aí eu não sabia que era o acampamento de Birigui que estava aqui, nós não sabia; quando cheguei aqui, eu dei de cara com Betinho, com a Cida, com Noé, com a Luzia, com o Carioca, o Maurício, todo mundo. E eu falei: "Mas o que estão fazendo vocês aqui?" Ele [Betinho] falou: "É o acampamento que veio para cá". Foi eles que invadiram essa fazenda aqui. Aí, quando nós chegou aqui de noite, todo mundo ansioso. Aquela tensão, menina do céu! Aí chegou o caminhão [da mudança] às 5 horas da manhã, e o Betinho falou: "Vê se o caminhão espera até uma e meia da tarde, para esperar a decisão do juiz" [...]. Aí não tinha só minha mudança, tinha outras várias mudanças de outros acampamentos que também tinham sido indicados. Um sol quente de novembro! A cabeça da gente fervia. Daí a pouco chega o juiz, a Polícia Federal e os padres, e cheio de polícia, promotor... O juiz entrou e rodou toda a fazenda ali, vendo onde iam ficar as pessoas, fora de área de risco.... 
E esse juiz que não saía lá de dentro. Todo mundo [aguardando] lá na porteira. Não ficou uma pessoa dentro dos barracos, e o medo dele falar não. Vai saber se o juiz vai dar posse ou vai falar para desocupar. Meu Deus do céu, e a tensão! Tem gente que chorava, chorando de alegria; aí, da aqui a pouco, esse juiz vem, aí o padre ainda foi falar, foi rezar, um pastor fez oração, e nunca que esse juiz falava, ora padre, ora pastor, outro fala, aí explica o significado da terra, tanta coisa falava. Pelo amor de Deus! Aí, quando ele falou que a fazenda era nossa, nossa! Aí, ninguém escutou mais nada do que ele falava. Aí, todo mundo gritando, tocando sanfona, tocando violão, gritando, chorando, outros se ajoelhando no chão; mas, olha, foi emocionante. Aí, quando foi de noite, o pessoal começou já a desmontar barracos [...]. Nós fomos o primeiro a entrar dentro da fazenda. Aí começou... Tinha uma mulher que passava e falava... Porque ninguém conhecia nós, só conhecia o pessoal que era daqui e o pessoal lá de Birigui. Aí, falava assim: “Tem gente que tá ali na bem boa, enquanto nós está carregando ainda madeira para fazer barraco, tem gente que está bem sossegada, que não sabe o que é sofrimento de acampamento. Não sofreu nada, já foi chegando e assentando". Aí, a Luzia falou para ela: "Dona Cida, a senhora está falando uma coisa que a senhora não conhece a história, você está vendo essa família ali, eles já têm quatro anos de acampamento, enquanto a senhora morava lá na vila, eles já passaram, já dormiram debaixo de chuva, debaixo de sol, foram despejados com polícia. Eles entraram dentro da fazenda primeiro do que todos nós, que já tava aqui, porque eles mereceram entrar dentro da fazenda, não foi à toa". (Cleusa, assentamento Macali, julho de 2006)

Como relatado no depoimento de Cleusa, eles não foram os únicos indicados que foram assentados. Na Fazenda Macali havia quarenta lotes a mais que o número de acampados que estavam na beira da estrada. Segundo Cida, que fazia parte do grupo de acampados do Dom Hélder e que nos primeiros meses foi a coordenadora do assentamento, para completar as vagas no assentamento, foram chamadas famílias de outros acampamentos. 
Esse foi o caso da família de Cido, um militante do MST, e de outras famílias que estavam acampando no Pontal; Cido me explicou:

no Pontal saiu uma área e aqui [outra] e foram escolhidas as famílias mais antigas do Pontal, para que, se quiserem, teria essa opção; aí, nos viemos com algumas famílias, olhamos a área, gostamos da região e viemos. (Assentamento Macali, dezembro de 2008)

Alguns acampados e assentados se orgulham quando convidam para um acampamento uma família que, tempos depois, consegue ser assentada. Esse foi o caso, por exemplo, de Mário, um acampado convidado por Edesmaria na época em que ela esteve com Cleusa e Alfredo na Cafeeira. Edes se orgulhava de ter conseguido levar famílias para a terra. Mário, um dos seus convidados, havia conseguido boas relações com o presidente do Sintraf, e, de fato, Edes me relatava que o próprio presidente havia ido pessoalmente ao acampamento, para convidar o Mário para entrar em uma fazenda que já havia sido desapropriada. Alguns meses depois ele foi assentado. ${ }^{10}$

Cida, a quem já fiz referência anteriormente, menciona que no assentamento há de indicados a indicados, já que "há um pessoal que não tinha tempo de barraco e está assentado”. Para ela, há os indicados como seu Alfredo, que não estavam acampando na Macali, mas tinham "tempo de acampamento, eram uma boa família para ser assentada". Nesse grupo também está o Mineirinho, que estava em outro acampamento e foi indicado, pois já tinha mais de "dez anos de barraco". No entanto, segundo ela, há outro tipo de indicados: "alguns nem tinham tempo de estrada e foram assentados"; e ainda há outros indicados, "os do apoio, que pagavam para manter barraco”. Segundo ela, muitos acampados da Macali não

10 Alguns dados recolhidos em campo mostraram que um dos critérios de indicação podia ser uma troca de favores em que uma série de compromissos e lealdades está em jogo. Precisaria de um investimento empírico e analítico maior, para problematizar essa questão; por esse motivo, nesta ocasião me limito somente a formular esse argumento à maneira de hipótese. 
queriam que os apoios fossem assentados e queriam tirá-los da lista. No entanto Cida se posicionou a favor deles. Para essa assentada, os apoios colaboraram para amenizar o sofrimento dos outros, eles pagaram para outros receberem e também doavam a cesta básica que lhes correspondia, para os moradores do acampamento. Ela não achava justo esses apoios terem pagado durante tanto tempo para manter barraco no acampamento e não serem assentados.

A distinção que Cida fez das famílias assentadas no assentamento Macali e principalmente dos indicados é também feita por outros assentados, que, como ela, passaram anos morando debaixo da lona. Nesse sentido, essa distinção, para esses assentados, passa por uma "lógica do merecimento", como assinalado por Loera (2006), acionada, no entanto, para se colocarem em uma espécie de hierarquia do merecimento. ${ }^{11}$ Para assentados como Cida, havia famílias que mereceram mais do que outras ganhar um lote de terra. Nesse sentido, em primeiro lugar estariam aqueles com tempo de acampamento e que acamparam nas terras da Macali, depois aqueles com tempo de acampamento e que pertenciam a outros acampamentos e acabaram sendo indicados para uma vaga na Macali, depois viriam os apoios, famílias que mantinham barraco, mas não moravam no acampamento e, finalmente, as famílias que não tinham tempo de acampamento e, por serem conhecidas ou parentes de famílias do assentamento ou de militantes do movimento, ganharam um lote.

A hierarquia do merecimento, me parece, pode ter diversas combinações, pois funciona dependendo também da posição, da condição dos indivíduos que a ela apelam e da situação. Os indivíduos, dependendo da situação, sabem como funciona essa hierarquia e tentam se adequar a ela.

Como mencionei anteriormente, a indicação da família Reis, assim como de outras famílias, para uma vaga na Macali, não foi bem-vista por outros recém-assentados, principalmente por aque-

11 Borges (2003) na sua etnografia sobre o Recanto das Emas, cidade satélite de Brasília, identifica entre as famílias do local um "ranking do merecimento" que posicionaria as famílias mais ou menos merecedoras de um lote. 
las famílias que haviam acampado na beira da fazenda e que não conheciam os Reis.

Alguns indicados, como no caso de Cleusa e Alfredo, nesse contexto de disputa entre os diferentes grupos de assentados (famílias de antigos moradores do local, o grupo das famílias vindas do Dom Hélder e os indicados), não perdiam oportunidade para fazer explícito seu tempo de acampamento, pois nesse contexto esse era o mais importante critério de legitimidade. Numa das reuniões que presenciei no assentamento, em 2007, na casa dos coordenadores, onde se discutia o destino que teria o dinheiro da cana $^{12}$ e se seria dividido também com os diversos indicados. Alfredo faz questão de relatar a história da lista que havia circulado no acampamento Capim, onde ele se encontrava acampado no momento da sua indicação. Segundo ele, na lista foram anotadas as pessoas que tinham mais tempo de acampamento. E ele "era dos poucos que tinha mais de três anos de acampamento, o resto das famílias eram tudo apoio”.

Já Cleusa me relatava em 2007 que havia usado o livro A espiral das ocupações de terra (Loera, 2006), em que se relata uma parte do percurso dela e da vida da sua família no acampamento Terra Sem Males, para demonstrar seu tempo de acampamento para aquelas famílias que não acreditavam neles. Cleusa percorrera lotes de vários vizinhos mostrando o livro e inclusive emprestou para aqueles que pediram para ler.

Para Alfredo e Cleusa, contar a história da lista dos velhos de acampamento da Capim ou mostrar o livro para os vizinhos do assentamento era uma forma de demonstrar seu tempo de acampamento e de mostrar que mereceram ganhar um lote de terra.

12 Quando os novos assentados entraram nos seus lotes, a propriedade toda estava plantada com cana-de-açúcar. Os coordenadores do recém-formado assentamento começaram negociações com empresas privadas, prefeituras e o Incra, para que a cana fosse removida e vendida, e o dinheiro fosse dividido entre os assentados. A cana foi removida, mas, até janeiro de 2009, não haviam recebido dinheiro algum, e se fazia referência a esse dinheiro e as disputas desse processo entre os assentados como o dinheiro da cana ou o negócio da cana. E aqueles assentados responsáveis pelas negociações ficaram conhecidos como procuradores da cana. 
Brenneisen (2003) também identificou, no estado do Paraná, a existência de procedimentos de seleção e de escolha de famílias para participarem de determinadas ocupações e acampamentos que viriam a se transformar em assentamentos. Segundo a autora, "o sorteio das famílias, procedimento até então considerado mais justo, passou a ser desqualificado enquanto "democratismo" e concebido como inadequado à modalidade organizacional pretendida pela direção do movimento nos assentamentos rurais" (2003, p.68).

Assim, em um dos casos por ela estudado nos anos 1990, o da Fazenda Verdum, as famílias selecionadas deviam concordar com a modalidade organizacional já previamente definida para aquele local. Como assinalado pela autora, na perspectiva dos militantes do MST, os anos de acampamento funcionariam como uma espécie de seleção natural, os anos de luta "tornar-se-iam imprescindíveis ao ajustamento das famílias a uma organização aos moldes idealizados pela direção do MST” (Brenneisen, 2003, p.67).

Reproduzo aqui um depoimento, colhido pela autora, de um militante do MST, em que se faz menção precisamente ao tempo, como um critério de seleção:

$\mathrm{O}$ processo de assentamento seleciona as pessoas. O oportunista não resiste a tanto tempo de sofrimento. Só resiste aquele que tem realmente necessidade e aquele que ideologicamente entende que o futuro é esse. O tempo vai selecionando. Os que não aceitam a organização vão abandonando. Além disso, o processo de acampamento serve também de evolução da consciência das pessoas. (Trecho de entrevista realizada por Brenneisen em setembro de 1992, apud Brenneisen, 2003, p.67)

Em outros casos apresentados pela autora, os militantes atribuem o fracasso de formas de organização coletiva nos assentamentos ao breve período de tempo que as famílias permaneceram acampadas, "associando, assim, tempo de acampamento, portanto, de sofrimento, a uma maior politização” (Brenneisen, 2003, p.67). 
Caume (2002) também identificou, através de relatos de assentados, a referência a disputas e desacordos entre diferentes grupos num dos assentamentos por ele estudado, no Rio Grande do Sul, por causa do procedimento de seleção adotado pelo Incra em concordância com a proposta do MST de selecionar famílias que tivessem disposição em desenvolver a produção futura do assentamento sob moldes coletivistas.

No final de 2008 um grupo de acampados e apoios do acampamento Famílias Unidas, revoltados com a indicação de algumas pessoas, dentre eles Biro, o coordenador do MST do acampamento, para uma vaga em uma fazenda, isto é, para serem assentados em uma fazenda próxima, decidiu mudar de bandeira e passou a acampar sob a bandeira do MTR ou do Sintraf dentro do próprio acampamento.

Esses acampados não concordavam principalmente com duas situações: que famílias com mais tempo de acampamento não tivessem sido escolhidas e que Biro, o próprio coordenador do acampamento e militante do MST, assim como outras famílias de militantes tivessem sido os primeiros a conseguirem terra antes de todo mundo no acampamento.

Neusinha, apoio do acampamento Famílias Unidas, a quem já fizemos referência anteriormente, era uma das que mais participavam das mobilizações organizadas pelo MST. Com a indicação de Biro e de outros militantes para serem assentados, Neusinha mencionava ter perdido "a fé no movimento" e decidiu apoiar a formação de outro grupo no acampamento, o grupo do Neguinho (Sintraf). Para ela, tanta luta não tinha servido de nada, pois não foram escolhidos os que cumpriram com as jornadas.

Já Teresa decidiu mudar para o grupo do Nino (MTR). Ela, além de não gostar de ter a obrigação de participar das jornadas, argumentava que não achava justo que "eles [militantes e coordenador] que já são assentados continuem no comando do acampamento”.

Neusinha, Teresa e outros acampados sob a bandeira do MST tiveram conhecimento de que havia quatro vagas para uma fazenda. Segundo eles, duas vagas foram sorteadas entre aquelas famílias com mais tempo de acampamento e as outras duas foram para Biro e 
para Rafael, cunhado de Biro, que mantém uma barraca montada no acampamento.

Segundo Nino, coordenador do MTR, "o pessoal do Biro [do acampamento] se revoltou por causa das vagas". Segundo esse coordenador,

Caiu quatro vagas dentro do MST. O acampamento era do MST e as vagas tinham que ser distribuídas pelo MST, só que aí o que o Biro fez, ele catou uma para ele, ele deu uma pro coordenador da Ipê, deu uma pro coordenador do MST, que nem acampado não era, e deu outra vaga para um que tinha barraco aqui, então foi por isso que o povo se revoltou [...]. Essas vagas não era para ser pro Biro, era para ser pro acampamento. (Nino, acampamento Famílias Unidas, janeiro de 2009)

Segundo Biro, "o movimento [o MST] deu cinco vagas para a militância". Ele respeitou "uma ordem de cima, para começar a atuar no Frente de Assentamentos". O Frente de Assentamentos faz parte da nova estrutura do MST. Segundo Biro:

o objetivo é recuperar a participação dos assentados na luta, isso só vai ser possível se a militância assentada faz um trabalho de base dentro dos assentamentos. O convite [para ser assentado] não é para ganhar terra, mas para cumprir com a obrigação de ajudar outros a ganhar terra, cobrando mais participação em jornadas e no trabalho de base que estaria ligado com a atuação do Frente de Massificação. (Biro, Castilho, janeiro de 2009) $)^{13}$

Um militante da Secretaria Estadual do MST-SP me explicava que, na reestruturação organizativa do movimento, proposta no En-

13 O Frente de Massificação substitui o Setor de Frente de Massa, para o qual trabalham militantes encarregados de organizar as mobilizações, especialmente ocupações, e massificar os acampamentos principalmente por meio do trabalho de base. 
contro Estadual realizado em 2008, foram abolidos os setores, para investir no que ele chamou de duas frentes: o de massificação e de assentamentos. Segundo ele, "todos os militantes devem dar atenção a essas frentes, um sem o outro não anda. No movimento", ele completou, "vimos que estava se perdendo a participação dos assentados. Agora vai ter militantes atuando diretamente dos assentamentos". Afinal, como ele me disse, "o assentamento não é uma ilha".

Militantes, dirigentes dos movimentos, coordenadores dos acampamentos e, inclusive, como vimos, os próprios assentados potenciais têm uma participação decisiva na indicação de pessoas para uma vaga ou um lote em um assentamento. ${ }^{14}$ Esse foi o caso, por exemplo, de algumas famílias do assentamento Macali, que foram convidadas por militantes do MST em trabalho de base, realizado em cidades próximas, para que se instalassem no acampamento na beira da fazenda pouco antes da terra ser liberada para assentamento. Essas são as famílias conhecidas entre os assentados da Macali como famílias da cidade; e há outras famílias que foram convidadas por parentes já assentados. Esse foi o caso de Tiago e Tina, filho e nora de Cleusa e Alfredo, que haviam passado anos junto com os pais, peregrinando por acampamentos, mas, quando o casal entrou nas terras da Macali, o casal de jovens decidiu morar numa cidade vizinha ao assentamento. Meses depois, sem perspectivas de emprego na cidade, eles foram morar com os pais, quando souberam que poderiam conseguir um lote de terra para eles no assentamento.

Ambos os grupos de famílias, os da cidade e os parentes, foram chamados para completarem as vagas remanescentes no assentamento.

Desse modo, alguns dos critérios para indicar alguém para uma vaga em um assentamento podem ser: o tempo que essas pessoas têm de acampamento, o fato de considerar uma família como boa, ou

14 Na teoria, os nomes das famílias escolhidas são colocados numa lista que depois é enviada para o Incra e são os representantes dessa instituição que elaboram uma lista definitiva, ou seja, a indicação funcionaria como uma espécie de pré-seleção. 
seja, que tenham cumprido com suas obrigações de acampado e que não sejam famílias problemáticas, e os vínculos de parentesco, amizade ou a proximidade que aquele que indica tem com os indicados.

A novidade da prática da indicação não está necessariamente na indicação em si ou na indicação específica de bons acampados ou de boas famílias ou de pessoas com um vínculo orgânico com os movimentos, como no caso dos militantes, conforme já vimos anteriormente, esse tipo de procedimento é comum no mundo das ocupações de terra, a novidade parece estar na institucionalização dessa prática por meio da criação do Frente de Assentamentos.

\section{Os compromissos}

Quando uma pessoa ou uma família é assentada, muitas vezes se inicia uma cadeia de compromissos e lealdades para com o movimento que possibilitou a obtenção de um lote de terra.

Feix (2001) acredita que a gratidão é uma das principais razões pelas quais assentados da região de Rondonópolis (MT) continuam vinculados ao MST. Segundo o autor, os assentados se sentem agradecidos com o movimento que os ajudou a conseguir um lote de terra. Por outro lado, esses assentados pretendem continuar recebendo benefícios ao continuarem participando do que o autor chama a "luta organizada no MST" (2001, p. 192).

Assentados, como mostra Loera (2006), sentindo-se comprometidos com o movimento, retribuem participando dos novos acampamentos. A autora mostra como assentados do assentamento Sumaré II em São Paulo, cumprindo o que eles chamavam de "compromissos", não só participaram do trabalho de base em cidades vizinhas ao assentamento convidando pessoas para que participassem da ocupação de terra que daria origem ao acampamento Terra Sem Males, mas os próprios assentados participaram da ocupação.

As próprias lideranças do MST reconhecem que a força desse movimento está nos assentamentos (Stédile e Fernandes, 1999). Segundo Loera: 
As obrigações parecem ter um significado mais concreto, elas se traduzem através da prática e das atividades do dia a dia no acampamento e no assentamento: arrecadar alimentos, participar das atividades, reuniões, trabalho de base, fazer ocupação, participar de passeatas ou marchas. Por outro lado, os compromissos parecem adquirir um sentido mais geral e abstrato; eles também se inserem numa dinâmica da obrigatoriedade e traduzem-se pelo cumprimento do conjunto dessas obrigações que se manifesta como uma espécie de troca com o MST. (2006, p.57)

Os dados recolhidos em campo, no entanto, mostram que os compromissos, no sentido mais abstrato, adquirem esse significado e são enunciados dessa maneira principalmente pelos militantes ou por aqueles que realizam trabalho para o movimento mas também pelos velhos de reforma, ou seja, por indivíduos que já cumpriram com seus anos de acampamento e faz vários anos que estão assentados. E o que militantes, apoios da militância e velhos assentados chamam de compromisso, para a maioria dos acampados são obrigações de acampado.

Por outro lado, os compromissos são de mão dupla, pois representantes dos movimentos também se sentem comprometidos e responsáveis pelas famílias acampadas e famílias que já foram assentadas, nesse caso, famílias que acompanharam durante meses ou anos, ao realizarem seu trabalho nos acampamentos. Afinal, a trama de relações entre dirigentes dos movimentos e acampados perpassa as "fronteiras" dos acampamentos e não termina com a conquista do lote de terra.

Um militante do MST que acompanhou de perto o grupo de famílias do acampamento Dom Hélder e o processo de assentamento na fazenda Macali manifestava sentir o compromisso de ajudar essas famílias. Lamentava que a questão do dinheiro da cana não tivesse sido resolvida, pois sabia que algumas famílias de assentados passariam dificuldade mesmo recebendo os fomentos do governo. Ele criticava a atuação da militância do MST do assentamento nessas negociações e mencionara que as famílias do Dom Hélder (que ele 
conhecia), agora assentadas, "não tiveram muita sorte, pois pegaram a pior militância da região".

Por outro lado, o compromisso não opera de maneira automática: se assentou, retribuiu. É bem sabido que no mundo social há uma infinidade de mediações, dentre elas, o tempo, podendo acontecer na própria dinâmica da retribuição uma infinidade de outras trocas ou inclusive a incerteza da troca. O compromisso, no caso dos assentados, vai sendo forjado precisamente com os anos de assentamento, e nesse processo o trabalho da militância do MST nos assentamentos é fundamental.

Dona Cida, por exemplo, do assentamento Sumaré II, se considerava militante do MST e era bastante atuante nas atividades organizadas por esse movimento na região de Campinas. Era coordenadora do assentamento e era a que realizava uma espécie de trabalho de base dentro do próprio assentamento, o que ela chamava de um trabalho de convencimento, isto é, convidava os assentados para que participassem das mobilizações e de outras atividades do movimento, lembrando-os da existência do vínculo com os sem-terra, ou o que ela chamava de compromissos. No entanto, a participação dos assentados não se daria, se eles não se dispusessem a fazê-lo, a cumprir com seus compromissos. Dona Cida organizava periodicamente reuniões e assembleias no assentamento onde se discutiam diversos temas relacionados à luta pela terra, organizava os festejos das datas comemorativas do MST e do assentamento e informava e organizava os assentados sobre as mobilizações. Com a morte da dona Cida, em julho de 2003, o assentamento, na percepção de alguns assentados, ficou parado. Em visitas realizadas meses após a morte da dona Cida, ouvi de vários assentados o mesmo comentário: que até não surgir outra dona Cida no assentamento, estariam parados, isto é, não haveria nem reuniões nem festas e ninguém para lembrar às pessoas sobre os compromissos com o movimento.

Devo mencionar que, tanto para assentados como para acampados, a primeira ocupação é o marco temporal de entrada no mundo das ocupações de terra. Alfredo, por exemplo, com pouco mais de um ano já como assentado, num contexto de disputa dentro do 
assentamento e num esforço por legitimar o merecimento do lote de terra, mencionava que havia sido indicado para ser assentado, porque na época tinha "mais de três anos de acampamento". Lembremos também o depoimento de Cleusa, quando conta que Luzia, outra acampada, no momento de entrada nas terras comentou para uma vizinha incrédula:

dona Cida, a senhora está falando uma coisa que a senhora não conhece a história, você está vendo essa família ali, eles já tem quatro anos de acampamento, enquanto a senhora morava lá na vila, eles já passaram, já dormiram debaixo de chuva, debaixo de sol, foram despejados com polícia.

Alfredo e Cleusa contam seu tempo de acampamento a partir da primeira ocupação em que participaram em 2002, incluindo o tempo que haviam passado fora dos acampamentos. Para esse casal, o tempo da espera e o tempo que passaram na cidade também contam no seu tempo de acampamento. A saída de um acampamento não significa "que tenha perdido a crença [na lona preta]" (Sigaud, 2004, p.18).

Aqui me permito abrir um parêntese, para mencionar que o caso da família Reis não é excepcional, é bastante comum que a saída de acampados seja temporária, mesmo se no momento da saída a decisão de sair se pense como definitiva. Sigaud (2004) também identificou em Pernambuco trabalhadores que decidiam sair dos acampamentos e que tempos depois regressavam ao mesmo acampamento ou se instalavam em outro. Ainda há o caso das saídas negociadas, como o de famílias do acampamento Famílias Unidas, que decidiram sair do acampamento durante alguns meses, mas, para não perderem sua vaga no acampamento e poderem voltar, aceitaram pagar uma taxa por todas as famílias acampadas do MTR mantendo, assim, o vínculo no acampamento.

Também entre militantes do MST, a referência à primeira ocupação de terras na qual participaram ou o primeiro acampamento onde estiveram é o marco zero da sua entrada no mundo das ocupa- 
ções de terra, e é o ponto de partida do que eles chamam do tempo de reforma.

Cido e sua família, assim como Cleusa e Alfredo, foram assentados na Macali. No entanto, participaram pela primeira vez de uma ocupação de terras em 1999. Cido é um jovem de 22 anos envolvido na militância estadual e nacional do MST. Quando lhe perguntei em 2008 quanto tempo fazia que ele estava no movimento, ele me respondeu que já era "velho de reforma", pois no ano seguinte completaria "dez anos de movimento". Cido tinha 13 anos quando participou, em 1999, com seus pais, de uma ocupação no Paraná, na região de Londrina. Segundo Cido, ele já tinha um tio assentado, e ele e sua família "se espelharam nessa possibilidade". Segundo ele, dessa primeira ocupação partiram para outras, mas sempre sob a bandeira vermelha do MST: "foi a primeira que nós chegamos e ficamos por aqui". No entanto, o envolvimento de Cido na militância do MST não começou com aquela primeira ocupação. Como relatado por ele, foi convidado várias vezes, quando estava acampando, para participar da militância: "da primeira e da segunda vez eu não quis, não é assim que aceita, não é tão fácil assim, porque, sabe, tem condições subjetivas também. Por que que você é um militante do MST? Para que ser militante do MST?".

Teve um intervalo de tempo entre os sucessivos convites e o aceite, para começar a participar. Hoje em dia, com seus 22 anos, ele já fez vários cursos de formação no movimento, é membro da Coordenação Nacional do MST e, inclusive, foi escolhido para passar alguns meses de intercâmbio fora do país. No entanto, como em qualquer mundo social, no mundo dos movimentos, o reconhecimento tem também suas contrapartidas. Cido me explicava: "aquele militante que saiu fora tem a obrigação de ficar no país e se dedicar por completo ao movimento durante dois anos”. Para Sigaud, nas trocas não são apenas objetos tangíveis que circulam sob a forma de dons, mas há também atenções, cuidados, respeito e reconhecimento. E ainda, para essa autora, os dons constituem obrigações e "são elas que vinculam os indivíduos no mundo social” (2007, p.149). 
Cido se considera velho de reforma e conta seus dez anos de movimento a partir da sua primeira ocupação de terra. Aquela primeira ocupação representa, para ele, um marco temporal, o momento a partir do qual começa a contar seu tempo de reforma; no entanto, esse tempo também faz referência à experiência adquirida e a seu know-how do movimento e do mundo das ocupações de terra.

Para outros militantes do MST, como Biro, assentado e coordenador do MST do acampamento Famílias Unidas, também a primeira ocupação e seu primeiro acampamento representam um marco temporal de entrada no mundo das ocupações de terra e no movimento, e, tal como para alguns assentados, a primeira ocupação é o que marca o começo do seu tempo de reforma.

O comentário do próprio Biro, a respeito de Nino, coordenador do grupo do MTR do acampamento Famílias Unidas, é significativo a respeito da importância que ele atribui ao tempo de reforma e à maneira como é contabilizado: "Nino teria tudo para ser militante do MST, ele é mais velho de reforma do que eu".

Nino, no começo dos anos 1990, participou pela primeira vez de uma ocupação, naquela época também participou ativamente com a militância do MST. Foi assentado na Fazenda Timboré, em 1992, na região de Andradina. Tempos depois ele vendeu seu lote e anos mais tarde acampou novamente. Recentemente, como já foi mencionado, formou seu próprio movimento. Já Biro participou pela primeira vez de uma ocupação em 2003, na própria Fazenda onde foi montado o acampamento Famílias Unidas. Para ele, foi nessa ocupação que ele despontou e marcou sua participação na militância do MST.

Assim parece que se faz referência a um tempo de reforma ou ao tempo de reforma de alguém como uma maneira de relembrar seu tempo de acampamento (tempo de barraco e tempo de luta). Seu significado, portanto, pode variar, dependendo da condição e da posição dos indivíduos no mundo das ocupações de terra.

Por outro lado, os compromissos aos quais fiz referência como uma espécie de troca com o MST ou retribuição ao movimento são vistos por militantes do MST e por assentados, ou inclusive uma 
combinação de ambos, militantes e assentados, como um componente inalienável do seu tempo de reforma; no entanto, esse compromisso vai sendo forjado precisamente com o tempo de acampamento e com os anos de assentamento e/ou com os anos de militância.

E finalmente, se esses compromissos, como acreditamos, fazem parte de um sistema de prestações, como assinalado por Mauss (2003), de dar, receber e retribuir, nesses ciclos de reciprocidade, como colocados por Bourdieu (2002), existiria também a incerteza da retribuição e a ação do tempo entre o dar, o receber e a retribuição.

\section{As dívidas}

A instalação de famílias numa propriedade como consequência de uma política de reforma agrária por parte do Estado é considerada como um projeto de assentamento. Esse projeto, como demonstrado por Caume (2002), só depois de ter passado por uma série de etapas que compreendem ações estatais específicas, etapas que podem ser completadas em até cinco anos, é que aquele espaço pode ser considerado um assentamento. ${ }^{15}$

Como assinalado pelo autor antes citado, nesse período de tempo o Estado pretende "possibilitar a estruturação social, política e econômica do assentamento e, finalmente, sua gestão pelos próprios agricultores" (Caume, 2002, p.56).

Nesse sentido, as famílias da Macali, quando foi realizado o trabalho de campo, encontravam-se ainda em processo de assentamento. Para as famílias que vivenciam esse processo, o Estado, através do Incra, de alguma maneira, aos poucos, vai tomando o

15 Como colocado por Caume (2002), dentre as atividades a serem realizadas com a intervenção do Estado durante esse período, estão: obtenção de recursos, realização de obras de uso comum no assentamento, levantamento de cercas, abertura de caminhos, água e saneamento e outras obras de infraestrutura no assentamento, assim como tornar a terra apta para o cultivo. 
lugar que o movimento tinha para eles no acampamento, embora também não haja uma ruptura nas relações com o movimento nem uma passagem abrupta da condição de acampado para assentado. No caso do assentamento Macali, os coordenadores do assentamento, durante os primeiros dois anos, foram os mesmos que coordenavam o acampamento Dom Hélder Câmara e que mais tarde, ao se juntarem ao acampamento da Fazenda Macali, continuaram no comando.

A continuidade das relações e a inexistência de uma ruptura entre a condição de acampado e assentado também se faz evidente no espaço físico do acampamento.

Em julho de 2006, seis meses depois de terem entrado nas terras, as famílias da fazenda Macali já estavam nos seus lotes, mas a maioria delas ainda se encontrava morando em barracos de lona e somente os próprios assentados e o Incra podiam reconhecer o limite dos lotes de cada uma das famílias, pois ainda não existia cerca nenhuma que marcasse qualquer divisão. Outros autores (Norder, 2003 e Antuniassi, 2003) também identificaram nos assentamentos por eles estudados uma continuidade da forma de vida dos acampamentos, principalmente a prevalência das barracas de lona e a inexistência de uma divisão dos lotes.

Somente algumas famílias, principalmente aquelas que haviam chegado das cidades próximas e contavam com alguns recursos, tinham conseguido construir barracos de madeira. A fazenda toda, salvo nos lugares onde existia reserva de mata, estava plantada com cana, e em alguns lotes a cana estava tão alta que mal se conseguia enxergar os barracos. Naquela época era comum ouvir relatos dos assentados sobre cobras e outros bichos "do mato" que tinham sido encontrados nos lotes ou nos barracos. Inclusive, na minha primeira visita ao assentamento, em julho de 2006, um dos assentados, brincando, mencionava que o fato de estar ainda morando entre mato e nos barracos havia sido planejado pelo movimento "para não sentir saudades das ocupações e do acampamento".

Essa situação começou a mudar somente em meados de 2007, mais de um ano e meio após a entrada nas terras e depois de rece- 
berem material para cercar o lote e para começar a construção das casas.

Foi nesse contexto que pude perceber que certos compromissos, inseridos numa dinâmica de obrigações e como parte de um ciclo de reciprocidade para os recém-assentados ou, para utilizar termos mais adequados, para os que estão em processo de assentamento, são percebidos como dívidas. Como destacado por Sigaud: "As obrigações são o que o observador percebe. Para os envolvidos nas transações, o que existe são as dívidas" (2007, p.149).

No entanto, para as famílias recentemente instaladas nos seus lotes, não são elas que estariam em dívida com o movimento, mas o movimento que mediou a obtenção de um lote de terra e o Incra como a entidade institucional que finalmente disponibilizou o lote é que estariam em dívida com eles, ou, como alguns assentados costumam dizer, os que têm um compromisso com eles.

Tentarei desenvolver melhor esse argumento retomando alguns exemplos etnográficos, não sem antes mencionar que é comum que os que estão em processo de assentamento façam referência ao Incra como os mesmos do MST, ou como tudo a mesma coisa. Não me parece que isso se deva a uma confusão dos assentados, mas à percepção das relações de cooperação existentes entre os movimentos e o Estado. Por outro lado, essas expressões são significativas à medida que revelam, como anteriormente mencionado, o lugar que os movimentos e o Estado vão deixando de ter ou vão tomando na vida das pessoas.

O Mineirinho, como o resto dos assentados, recebeu vários metros de arame para cercar seu lote, assim como outros materiais. Mas, tal como outros assentados, ele não usou o material no seu lote, ele o vendeu. O Mineirinho foi questionado por outros vizinhos e por um dos coordenadores do assentamento por ter vendido o material. Foi nessa conjuntura, na ocasião de uma visita ao coordenador na qual acompanhei seu Alfredo, que encontramos o Mineirinho em frente do lote do coordenador.

Reproduzo aqui a conversa que o coordenador teve com esse assentado na ocasião: 
Coordenador - Fiquei sabendo que o senhor andou vendendo material, não pode viu. É material para o senhor usar no lote. O Incra deu esse material para a gente usar no lote.

Mineirinho - E tudo que tiraram de mim então, tanto tempo, o sofrimento que passei não vale o arame?

Coordenador - Tem monte de gente aqui [no assentamento] que passou pelo mesmo que o senhor, que ficou anos debaixo da lona, igual ao senhor, e nem por isso andam vendendo tudo [o que o Incra deu]. Estão de olho [o Incra], o senhor acha que não? O senhor vai ter que repor [o arame].

Mineirinho - Nada, eles são os que me devem. Agora estou na minha terra e faço o que eu quero.

O Mineirinho montou novamente em sua bicicleta e foi embora. Não fiquei sabendo o que aconteceu depois e qual foi o desenlace da história da venda do arame, mas depois do acontecido tive informações de que alguns assentados, dentre eles o Mineirinho, chegaram a pensar em deixar o lote, pois, para algumas famílias, estava sendo difícil cumprir com as condições estabelecidas pelo Incra, dentre elas plantar um determinado tipo de cultivo, não deixar a terra sem trabalhar mais de três meses e usar os fomentos recebidos conforme estabelecido por esse órgão federal. ${ }^{16}$

Assim parece que o Mineirinho, ao contrário do que ele havia enunciado, realmente não podia fazer o que queria com "sua" terra. O lote, como um dom disponibilizado pelo Estado, implicava algumas obrigações e, afinal, o assentado devia dar sua contraparte.

Quirós (2006) menciona que, para o caso dos participantes das organizações de piqueteros em Buenos Aires, a relação com o Estado

16 Os assentados me explicavam que a cada fomento que eles recebem vem também uma lista das coisas que devem e podem comprar com esse dinheiro. Em maio de 2006, por exemplo, os assentados receberam 2.400 reais do primeiro fomento. Esse dinheiro deveria ser usado para cobrir despesas em alimentos da família, principalmente alimentos não perecíveis. Em agosto de 2007, receberam um segundo fomento do mesmo valor do anterior, que chegou com uma lista de ferramentas e de material, para começar a construção da casa. 
se funda numa linguagem do dar e do receber. A participação das pessoas nas marchas, os piquetes, os protestos, tornam-se performances coletivas, que indicariam ao Estado quais benefícios se quer conseguir.

Na percepção do Mineirinho, seus anos de acampamento (seu tempo e o sofrimento) lhe davam o direito de usar os dons recebidos como bem achasse. Por outro lado, ele não sentia que estava em dívida com ninguém, pelo contrário, na percepção dele era o Incra que estava em dívida com ele. Para ele, o valor do arame era pouco comparado com o valor do seu tempo e do sofrimento passado durante anos debaixo da lona. Para esse assentado, o tempo e o sofrimento se tornam bens que, mesmo sem serem equivalentes, podiam ter como contradons bens materiais.

Sigaud, em artigo publicado em 2007, focaliza um momento de interrupção das trocas nas grandes plantações da Zona da Mata Pernambucana e, através do relato de um trabalhador, mostra como os dons se tornaram objetos de cálculos monetários em um contexto de mudança, nos códigos de conduta da região e das formas de relacionamento entre trabalhadores e patrões. Para a autora, "não faz sentido opor o mundo dos dons ao mundo das mercadorias, pois no concreto da vida social, tudo está misturado” (2007, p.149).

João e Roberta são um casal de assentados. Eles se conheceram seis anos atrás nas andanças pelo mundo das ocupações de terra em um acampamento montado no município de Jacareí (SP). Ambos já haviam passado por outros acampamentos de sindicatos e do MST. Em Jacareí ficaram acampados durante dois anos em um acampamento da CUT, mas decidiram mudar para outro acampamento mais organizado, onde tivesse a bandeira do MST, já que, segundo eles, "o MST sabe lidar melhor com os problemas dentro do acampamento, é mais organizado”.

Naquela época João começou a trabalhar em São Paulo fazendo bicos. Ele costumava passar quinze dias em São Paulo e depois voltava para o acampamento, onde Roberta ficava. Esse casal, tal como outros recém-assentados, depois de ter peregrinado por vários acampamentos, entrou na Macali, no final de 2005. 
Eles, como o resto dos assentados, receberam os fomentos do governo para alimentação e para construção da casa. João, tal como Alfredo, decidiu construir sua casa ele mesmo, para não ter que pagar outra pessoa. E também, como muitos outros assentados fizeram, quando os materiais para construir a casa chegaram, ele ficou com o mínimo de material necessário e vendeu outra parte. Inclusive, por ter vendido parte do material, ele não conseguiu construir a cozinha da sua casa, pois no fundo do seu quintal ainda prevalecia um pequeno barraco, onde tinha o fogão a lenha. O lote do casal, após dois anos de terem se assentado, era um dos poucos no assentamento que praticamente não tinha nada plantado; no entanto, sempre tinha vacas pastando no terreno. Seis das vinte vacas, João comprou com o dinheiro do fomento, o resto eram de dois vizinhos, para quem ele alugava o terreno para pastagem, ganhando também um dinheiro por cuidar dos animais. Assim, o casal sobrevivia não só do aluguel do terreno, mas também de pequenos serviços e trocas com os vizinhos e dos 60 reais por mês do bolsa-família que Roberta recebia.

João era criticado pelos vizinhos no assentamento e principalmente por alguns assentados que mantinham um vínculo mais estreito com lideranças do MST por não se dedicar a seu lote e não ter nada plantado, mas principalmente por ter gastado mal o dinheiro dos fomentos.

João, ciente das críticas e quando interrogado por mim sobre o assunto, justificou o uso que ele fez dos recursos recebidos recorrendo ao mesmo argumento do Mineirinho. Para João, ele passou dez anos de luta, dedicando tempo e esforço ao movimento e o que ele fazia com seu lote, com seu dinheiro e com seu tempo era assunto dele e, mais, como ele me disse, "ainda assim são eles [o movimento] os que ficam me devendo".

Para João, pelo tempo que passou em acampamentos de sem-terra, ele merecia ser assentado, fazer uso do seu tempo e dos recursos recebidos como ele quisesse. O tempo em acampamentos e sua dedicação, em suma, seus anos de luta se tornavam bens de 
alto valor quando comparados com o dinheiro ou material recebido como assentado.

Assim, o tempo, a dedicação, o sofrimento que no tempo do acampamento são percebidos como aquilo pelo qual tem que se passar, como condição sine qua non para poder ser candidato à reforma agrária, estando no processo de assentamento, são percebidos pelos assentados como dádivas que criam uma obrigação à inversa: faz-se uma dádiva que depois dará rendimentos.

Cheguei a essa conclusão inspirada na análise de Bohannan (1973) sobre a sociedade Tiv. Para ele, a dívida (injô) é uma obrigação que se estabelece numa rede complexa de relações de status, dependentes umas das outras. E a obrigação assume uma forma material. Na interpretação de Gluckman sobre o trabalho de Bohannan, "acumulam-se obrigações que 'renderão', assim como se acumula uma fazenda que dará frutos” (1973, p.45).

Para os recém-assentados, esse momento é o momento do acerto de contas com o movimento, de serem donos do seu próprio tempo, de se dedicarem a seu lote e de usarem como melhor acharem os dons recebidos. Para Cleusa, seu lote representa segurança, estabilidade e uma oportunidade de reconstruir sua vida. Ela resumia tudo isso numa frase: "macaco velho tem medo de sair do galho". Para Cleusa, eles, como assentados, não têm por que cumprir com obrigações de acampado, na interpretação dela, o compromisso, como ela me disse, é do movimento.

Diferentemente dos assentados anteriormente mencionados, há outras famílias da Macali que cumprem seus compromissos com o movimento.

Em novembro de 2006, foi organizada uma série de mobilizações na região em parceria MST-sindicatos, o objetivo era fazer pressão para a liberação de várias fazendas improdutivas e para a liberação de créditos para os assentados da região. Uma das atividades na qual foi pedida a participação dos assentados foi na ocupação do Banco do Brasil, que aconteceria na cidade de Ilha Solteira.

$\mathrm{Na}$ ocasião, como relataram assentados da Macali, "só participaram os militantes”, ou seja, as famílias de assentados nas quais al- 
guns dos seus membros participam da militância do MST. Famílias que, de fato, são facilmente identificáveis, inclusive, para quem chega de fora, pois mantêm a bandeira do MST visível no lote.

Membros da família de Cido, a quem já fizemos referência anteriormente, foram uns dos participantes das mobilizações. O próprio Cido não participou, pois, como ele me disse, "sempre estou com a mala pronta, indo para onde o movimento me leva". Por causa de seu trabalho como militante do MST, não acompanha a movimentação do assentamento porque não tem tempo; segundo ele, "raramente está no assentamento”, já que passa vários meses do ano fora, formando-se, ou em atividades do movimento e volta para a casa para ficar só alguns dias, para depois ter que sair novamente. No entanto, sabe que "a [sua] família cumpre com seus compromissos".

Diferentemente daqueles jovens que se envolvem com a militância do movimento e que tem oportunidade de viajar, conhecer outras pessoas fora do círculo familiar, muitos jovens nos assentamentos não estão satisfeitos com sua vida como assentados, acham a vida nesses espaços tediosa e rotineira, e lhes parece difícil cumprir com as obrigações familiares de ajudar na roça e nas tarefas cotidianas no lote, muito mais ainda se são jovens que passaram pela experiência do acampamento, onde sempre havia coisas novas acontecendo, sempre uma ocupação para participar, uma marcha, e pessoas de fora do universo familiar visitando o acampamento.

A militância no MST, na percepção de jovens como Cido é uma opção de vida que se traduz como liberdade e que se opõe à ideia de estarem parados, presos, como ouvi de jovens no assentamento. Esse é o caso dos próprios filhos de Cleusa e Alfredo. Marcos, o filho do meio, está sempre numa contínua busca de trabalho fora do assentamento. Para ele, a vida para além do círculo familiar se lhe apresenta como mais interessante. Paradoxalmente é precisamente o salário que Marcos ganhava realizando trabalho fora do assentamento o que ajudava a pagar as dívidas e a manter a família no assentamento, assim como a adquirir outros bens, como carro, carroça, geladeira, vacas, entre outros. Marcos foi quem ajudou a pagar a dívida do banco (600 reais), pagou também mais 300 reais 
da madeira da cerca do lote e inclusive ajudava a pagar a dívida que Cleusa tinha no mercadinho da cidade, mais de 700 reais, dívida que de fato também era vista como um compromisso. ${ }^{17}$ É comum, no assentamento, que o dinheiro dos fomentos seja usado muitas vezes para pagar dívidas anteriores acumuladas durante os anos de acampamento, e seja reposto depois, precisamente com o salário dos jovens. Antuniassi identifica que muitas vezes a condição de dívida dos assentados os impossibilita de cultivar a área total dos lotes destinada a cultivo, no entanto é o salário dos jovens "que permite ao grupo familiar ampliar o consumo, é com o dinheiro por eles obtido que o grupo familiar tem acesso a bens duráveis como geladeira, televisão, aparelho de som e, sobretudo, ampliar e melhorar a construção da casa” (2003, p.53).

Feix (2001) nos assentamentos por ele estudados no Mato Grosso identificou a predominância de casais adultos, de um grande contingente de assentados de idade avançada e de poucos jovens, já que estes últimos, na percepção do autor, preferem ficar nas cidades, estudando ou trabalhando.

Na percepção dos assentados, assim como para os acampados, é melhor um assentamento que esteja localizado perto de uma cidade, até porque dessa maneira os filhos, tendo essa opção de lazer ou de trabalho por perto, acabam ficando com os pais. Nesse sentido, para esses jovens, a cidade e seus serviços é também um lugar de distração ou espaço de lazer e a maioria, durante os finais de semana, se desloca para a cidade, para se reunir com outros jovens e assim sair da rotina. Segundo Antuniassi, "como a infraestrutura e as condições de lazer no assentamento são precárias, os jovens vão para as cidades vizinhas, e nesse caso os rapazes têm maior liberdade de circular que as moças" (2003, p.57). E, mais do que isso, a cidade, mesmo que de maneira momentânea, permite a alguns jovens experimentar a sensação de estarem "soltos", como um jovem do assentamento me disse.

17 Para uma discussão mais apurada sobre esse tipo de dívida, ver Villarreal (2008) e Arensberg e Kimball (1973). 
Inclusive alguns assentados acreditavam que "as famílias [originárias] da cidade" e as dos antigos moradores da fazenda são as que "se deram melhor com o assentamento", pois são pessoas que, além de conhecerem bem a região, mantêm vínculos estreitos com uma rede de amigos, parentes e conhecidos nas cidades próximas, que acabam dando preferência à compra dos produtos por eles produzidos no assentamento. A condição de assentado, para Leite et al. (2004), não necessariamente implica uma mudança espacial, permanecendo nos limites da grande propriedade na qual residiam. Ainda para Leite et al., "a criação dos assentamentos pode estar se constituindo num mecanismo importante de recomposição das famílias de trabalhadores antes separadas (inclusive por processos migratórios) ou então estar permitindo a manutenção de comunidades antes existentes" (2004, p.117). ${ }^{18}$

Gostaria de concluir esse capítulo mencionando que, conhecendo essas diferentes percepções que no mundo das ocupações de terra se têm dos compromissos, me atrevo a sugerir, inspirada em Leach (1995), que, mesmo existindo uma relação desigual entre aquele que dá e aquele que recebe, nesse mundo social os indivíduos estariam em relação de dívida constante e, ainda, como menciona Sigaud (2007), a dívida é mantida para conservar a relação. Ora se está numa posição, no ciclo de reciprocidade que se percebe como o momento de dar, ora de receber, ora de retribuir.

A criação do Frente de Assentamentos pelo MST, a meu ver, não só torna evidente a importância que os assentados têm na conformação de novos acampamentos, como também o Frente parece ser um mecanismo ou uma forma de institucionalizar a obrigação, ou, em termos nativos, o compromisso, uma forma estrutural do mundo social. Dessa maneira garantem não apenas a continuidade do mundo das ocupações de terra, mas sua renovação. Certos indivíduos indicados para atuarem desde os assentamentos cum-

18 Segundo os autores, $62 \%$ dos responsáveis pelos lotes, em assentamentos de seis estados pesquisados, têm parentes em outros lotes dentro do mesmo assentamento. 
prem seus compromissos e põem novamente em funcionamento o ciclo da reciprocidade, inserindo-se assim em outra cadeia de interdependências com assentados, convidados a cumprirem com seus compromissos, realizando trabalho de base e participando de novas ocupações.

Quem sabe aqueles militantes atuantes no Frente de Assentamentos possam talvez aproveitar a massa jovem dos assentados, oferecendo, precisamente como retribuição, a possibilidade, ao cumprirem com seus compromissos, de experimentarem a liberdade. 


\section{ConsideraÇõES FINAIS: TEMPO DE ACAMPAMENTO}

O tempo é um tema caro à antropologia e tem sido tratado por autores clássicos e consagrados como uma das dimensões da vida social através da qual podemos ter acesso não somente às maneiras pelas quais os grupos se relacionam entre si, mas ao modo como hierarquizam suas experiências expressas em temporalidades distintas. O tempo é, pois, mais do que uma medida cronológica.

No clássico Os nuer ([1940] 2002) Evans-Pritchard dedica inúmeras páginas do seu livro à descrição dos conceitos nativos nuer de tempo e espaço. Noções que estariam intimamente relacionadas entre si. $\mathrm{O}$ autor faz um recorte analítico da concepção do tempo entre os nuer e identifica o que poderíamos chamar de duas temporalidades: o tempo ecológico e o tempo estrutural. O primeiro deles é um reflexo das relações do povo nuer com o meio ambiente, e Evans-Pritchard o identifica como um tempo cíclico. As estações, por exemplo, fariam parte do primeiro tempo e mais do que representar mudanças climáticas estariam relacionadas com atividades do grupo em determinados momentos. Os conceitos nativos das estações com que são representadas essas temporalidades não seriam então, segundo o autor, puras unidades de contagem de tempo: mas sim de amontoados de atividades sociais. Já o segundo tempo seria um reflexo das relações que os indivíduos ou grupos estabelecem 
entre si. Nesse sentido, o tempo estrutural é o que fundamenta as alianças políticas e os vínculos entre os diversos grupos e linhagens. Entretanto, um e outro tempo são determinados pelas relações sociais. Ambas as temporalidades fariam referência a sucessões de acontecimentos, e a contagem do tempo estaria relacionada às formas de relacionamento dos grupos sociais.

Já Mauss ([1904-05] 2003a), no seu conhecido "Essai sur les variations saisonnières des sociétés Eskimos. Étude de morphologie social" aponta para a natureza social do tempo. O tempo como marcador do ritmo da vida social. O autor analisa vários aspectos da vida social entre os esquimós e identifica que as variações da sociabilidade do grupo estão relacionadas com duas estações do ano: inverno e verão, estações que marcam um ritmo determinado, um ritmo regular coletivo da vida social. Nas palavras do autor:

A uma comunhão real de ideias e de interesses na densa aglomeração de inverno, a uma forte unidade mental religiosa e moral, opõem-se um isolamento, uma dispersão social, uma extrema pobreza moral e religiosa no espalhamento de verão. (Mauss, 2003b, p.499) $)^{1}$

Existiriam, portanto, duas maneiras de se agrupar, e a essas duas formas de agrupamento corresponderiam dois sistemas jurídicos, duas morais, dois tipos de economia doméstica e vida religiosa. Para Mauss, a divisão inverno/verão é estruturante da organização social dos esquimós: "É que as estações do ano não são a causa imediatamente determinante dos fenômenos que elas condicionam; sua ação ocorre sobre a densidade social que regulam" (2003b, p.502). ${ }^{2}$ Desse

1 “A une communauté réelle d'idées et d'intérêts dans l'agglomération dense de l'hiver, à une forte unité mentale religieuse et moral, s'opposent un isolement, une poussière sociale, une extrême pauvreté morale et religieuse dans l'éparpillement de l'été" (Mauss, 2003a, p.470).

2 "C'est que les saisons ne sont pas la cause immédiatement déterminante des phénomènes qu'elles conditionnent; elles agissent par leur action sur la densité social qu'elles règlent"' (2003a, p.474). 
modo, com as variações do tempo, também varia a forma do grupo, dos relacionamentos, ou do que ele chama a morfologia social do grupo. Mauss chega à conclusão de que esse fenômeno social não é exclusivo dos esquimós; para ele, qualquer vida social passa por momentos de intensa interação social e de repouso, nunca estando em um mesmo ritmo nas diferentes épocas do ano.

Norbert Elias (1998) vai além. Para ele, aquilo que chamamos "tempo" não é um dado da natureza existente independente do ser humano, assim como não é uma representação subjetiva inerente à consciência. Muito pelo contrário, o tempo é um tempo social e constitui uma complexa rede de relações; é um mecanismo regulador da convivência humana; é histórica e socialmente apreendido e produzido. Elias propõe então pensar o tempo em termos relacionais, compreender o tempo no contexto onde é produzido, pois, "a atividade humana de sincronização ou 'temporação"” está relacionada com a complexidade da vida social. Assim, para o autor:

O que chamamos "tempo" significa, antes de mais nada, um quadro de referência do qual um grupo humano - mais tarde, a humanidade inteira - se serve para erigir, em meio a uma sequência contínua de mudanças, limites reconhecidos pelo grupo, ou então para comparar uma certa fase, num dado fluxo de acontecimentos, com fases pertencentes a outros fluxos, ou ainda para muitas outras coisas. (1998, p.60)

A percepção de tempo como socialmente constituído e principalmente como símbolo relacional resolve o problema da velha dicotomia ação/representação. Afinal, o tempo é atividade. E quando tais atividades fazem sentido para um determinado grupo ou sociedade, elas são sintetizadas, integradas, hierarquizadas e temporalizadas.

O "tempo da política", categoria nativa identificada por Palmeira (2002) entre populações camponesas do Nordeste brasileiro, é um bom exemplo do anterior. Segundo o autor, para essas populações esse "tempo" é um período em que o cotidiano é subvertido, um momento em que divisões são mostradas e no qual "parece estar em jogo um rearranjo de posições sociais” (2002, p.172). 
É um tempo, segundo o autor, em que também determinados tipos de lealdades são solicitados da população camponesa.

Ainda, para Palmeira, o tempo, quando combinado com outros termos (como tempo de Arraes, tempo do sindicato, tempo das greves) pode corresponder não simplesmente a uma datação, mas

Parece estar em jogo menos uma concepção qualquer de tempo como o representamos habitualmente, linear, ou cíclico, cumulativo ou não cumulativo, e mais uma certa maneira de a população recortar/representar a estrutura social. Trata-se menos de estabelecer um desenho qualquer de temporalidade e mais de descrever ou de postular um conjunto de atividades adequadas e um ritmo próprio à sua consecução em um determinado momento. (2002, p.172)

\section{Dessa maneira,}

embora tudo seja temporalizável [...] só é temporalizado (isto é, transformado em tempo, como o tempo da política, o tempo das festas, etc.) o que é considerado socialmente relevante pela coletividade em determinado momento. (2002, p.175)

O tempo de acampamento também, como o "tempo da política" identificado por Palmeira, é uma categoria nativa que faz sentido para um grupo ou população ao qualificar um conjunto de atividades ou de comportamentos específicos. No entanto, o tempo de acampamento não tem o mesmo estatuto de excepcionalidade, de subversão do cotidiano para a população que vivencia esse tempo, como o tem o "tempo da política" para as populações do Nordeste, do mesmo modo que também não seria um recorte na regularidade social.

O tempo de acampamento também se diferencia do "tempo do acampamento”, ao qual faz referência Caume (2002) como uma rememoração da luta, como uma lembrança que assentados teriam de um determinado tipo de sociabilidade. Já Schmitt (1995), no seu estudo de caso realizado em um acampamento no Rio Grande do Sul, se refere à experiência do acampamento como "tempo do acampamento", e o acampamento como um espaço de vivência ou de socia- 
bilidade. No entanto a autora focaliza essa vivência como o momento de constituição do que ela chama a identidade social do "colono sem-terra". Schmitt também faz referência a um "tempo da luta" relacionado à institucionalização de formas de participação política e de aprendizado de um sistema de regras por parte dos acampados. No entanto, esses tempos se restringem ao contexto do acampamento.

O tempo de acampamento aqui analisado se assemelha mais à categoria "tempo de Brasília", identificada por Borges (2003). "O tempo de Brasília" seria uma categoria nativa que se tornou um critério que orienta a concessão de benefícios dados pelo governo do Distrito Federal a um determinado tipo de população. Conforme a autora, para receber esses diversos benefícios ofertados pelo governo local em forma de "dons" "a população é hierarquizada num ranking de merecimento" (Borges, 2004, p.25). O "tempo de Brasília", como comprovante do tempo de residência em Brasília, seria uma das fórmulas mágicas através das quais se calcula o quantum de merecimento da população. Nas palavras da autora: "o 'tempo de Brasília', embora seja somente uma das variáveis que compõem a equação que fornecerá o número de pontos de cada indivíduo inscrito para o recebimento de benefícios estatais, acaba dando nome e sentido a todo o processo social em que é necessário envolver-se para alcançar esse pertencimento local" (2004, p.26).

O tempo de acampamento é um código social dentro do mundo das ocupações de terra e tem se tornado, nos últimos anos, uma referência para representantes do Incra e de órgãos como Itesp no estado de São Paulo como critério para dotação de lotes de terra. Por outro lado, para as lideranças dos movimentos que organizam e gerenciam os acampamentos, o tempo de acampamento é sim um critério para indicar qual população será merecedora de um lote de terra. Como vimos, as organizações de trabalhadores têm, nesse processo, uma participação decisiva.

Por outro lado, o tempo de acampamento não é uma mera medida cronológica, na medida em que não só indica o tempo que de fato uma pessoa passa debaixo da lona num acampamento, mas também é um demarcador de prestígio e um ordenador das relações sociais dentro dos acampamentos, especificamente das relações de status. 
Os participantes das ocupações logo aprendem que não basta ter um barraco em um acampamento para ser candidato à reforma agrária, para isso também há que cumprir com uma série de obrigações e critérios. Em alguns acampamentos é preciso se dedicar ao seu barraco, caprichar na sua arrumação, sofrer e passar dificuldades debaixo da lona; em outros também é preciso ocupar, convidar pessoas para participar de outros acampamentos, correr atrás de recursos para ser merecedor de um lote de terra. Nesse processo, não só o tempo pode se tornar um bem que pode ser acumulado, trocado e negociado, mas também a dedicação, o sofrimento, o barraco, a participação, a confiança, os acampados tornam-se recursos que podem ser mobilizados.

Assim, o tempo de acampamento e suas variantes, de barraco, de luta e de reforma, constituem formas diferenciadas de vivenciar a experiência do mundo das ocupações de terra dependendo da situação e da posição dos indivíduos no mundo das ocupações de terra. E, por outro lado, nos mostram que a vivência da reforma agrária não tem um sentido ou um significado único, mas diversos.

Afinal, um dos interesses centrais da pesquisa foi precisamente o de entender como o tempo de acampamento é vivenciado pelos indivíduos e qual o significado atribuído a essa vivência.

Sigaud (2006) chamou a atenção sobre o significado e a maneira como as pessoas que participam dos acampamentos se colocam diante dos movimentos que organizam as ocupações. Para a autora, o uso que os acampados fazem do verbo estar - "estar com os sem-terra" ou "estar com eles" - nos diz muito a respeito de como as pessoas vivenciam sua relação com o movimento e com os acampamentos, precisamente de modo relacional. ${ }^{3}$ Pois "é precisamente através desses elementos da linguagem que consegui-

3 Segundo Elias, "os grupos ligados entre si sob a forma de uma configuração de estabelecidos-outsiders são compostos de seres humanos individuais. $\mathrm{O}$ problema é saber como e por que os indivíduos percebem uns aos outros como pertencentes a um mesmo grupo e se incluem mutuamente dentro das fronteiras grupais que estabelecem ao dizer 'nós', enquanto, ao mesmo tempo, excluem outros seres humanos a quem percebem como pertencentes a outro grupo e a quem se referem coletivamente como eles" (2000, p.38). 
mos compreender o significado vivido da relação mantida pelas pessoas" (2006, p.18, tradução minha). ${ }^{4}$

A autora, comparando a participação das pessoas nas organizações de piqueteros na Argentina e nas ocupações de terra no Brasil, menciona que:

Nem "piquetero" e nem "sem-terra" constituem identidades reivindicadas por aqueles designados sob esses termos. Em ambas as situações, as pessoas costumam dizer que "estão" com as organizações. "Estar" é, em castelhano e em português, o verbo adequado para designar um estado transitório; [...] as organizações piqueteras e os movimentos de ocupação de terra estão também constituídos por pessoas que se vinculam a eles de modo momentâneo, e que não necessariamente conformam um corpo com suas lideranças. Possuem uma relação distinta à dos militantes que encaram o movimento e que vivem por e para o movimento. No entanto, na medida em que se sentem ligados à organização, atuam segundo as regras do jogo, e dão vida aos movimentos e suas performances. (ibidem, p.18-9, tradução minha) ${ }^{5}$

Por outro lado, no mundo das ocupações de terra, a cada mudança de acampamento, o percurso de uma família extensa torna evidente as relações de dependência não apenas entre acampados,

4 Bourdieu (1982) é outro autor que também chama a atenção sobre a importância de prestar atenção na linguagem. Para ele, as palavras são atos e a língua, além de ser um instrumento de comunicação, é também um instrumento de poder.

5 'Ni 'piquetero', ni 'sin tierra' constituyen identidades reivindicadas por aquellos a los que se designa con esos términos. En ambas situaciones las personas suelen decir que 'están' con las organizaciones. 'Estar' es, en castellano y en portugués, el verbo adecuado para designar un estado transitorio; [...] las organizaciones piqueteras y los movimientos de ocupación de tierra están también constituidos por personas que se vinculan a ellos de modo momentáneo, y que no necesariamente conforman un cuerpo con los líderes. Poseen una relación distinta a la de los militantes, que encarnan el movimiento y que viven por y para el movimiento. Pero en la medida en que se sienten ligadas a la organización, actúan según las reglas del juego, y dan vida a los movimientos y sus performances." 
assentados e lideranças dos movimentos que organizam as ocupações, mas também entre os anteriores e representantes de governo e políticos locais.

Segundo Macedo, ao estudarmos os acampamentos, há que levar em conta as relações com a política local e os órgãos do governo, pois "as dinâmicas sociais desenvolvidas nos acampamentos só podem ser compreendidas quando relacionadas ao quadro institucional que as envolvem" (2003, p.10).

A evidência da existência dessas relações no cotidiano dos acampamentos nos permite, por um lado, afirmar que existem relações de cooperação entre Estado e movimentos e, por outro, questionar afirmações de senso comum, como a que diz que existiria um confronto entre eles. Feix (2001), por exemplo, menciona que organizações como o MST se destacam pela sua "oposição sistemática ao governo e ao Estado” (2001, p. 252). Já Caume (2002) denuncia a influência do MST nos critérios de seleção dos assentados que, na visão dele, deveria ser tarefa exclusiva do Incra.

Interpretações como as anteriores são muito comuns na literatura sobre movimentos sociais. No entanto, como vimos, alianças são tecidas e mecanismos de cooperação são forjados entre grupos e instituições que, como mencionam Grimberg, Fernández e Rosa (2009), são vistos como antagônicos, porém, inclusive mantêm obrigações recíprocas. Ainda, essa cooperação entre Estado e movimentos se intensifica dependendo também do contexto e de conjunturas políticas e sociais determinadas.

Como assinalado por Beletti et al. (2008, p.298, tradução minha) para o caso do MST:

O MST reivindica autonomia perante o Estado, mas isso não significa que eles não negociam com o Estado, ou que as ocupações e assentamentos do MST não dependam dos recursos do Estado. ${ }^{6}$

6 "The MST claims autonomy from the state, but this does not mean that they do not negotiate with the state, or that the MST's occupations and settlements are not dependent on the state for resources." 
Os recursos, como foi mencionado, é um termo nativo usado principalmente pelas lideranças dos movimentos para descrever não só a circulação de recursos materiais entre acampados, assentados, lideranças dos movimentos e autoridades locais, mas também recursos sociais.

Ao seguir o fluxo dos recursos: como circulam, de quem e para quem e em que circunstâncias se fazem evidentes as tramas de relações. Tramas que se estendem para além dos acampamentos, ficando assim cada vez mais claro que no mundo das ocupações de terra, como em qualquer mundo social, as pessoas estão indiscutivelmente ligadas umas com as outras. O conjunto dessas tramas de relações constitui o que Elias (2000 e 2005) chama de figuração.

As relações de interdependências recíprocas fazem que cada ação individual dependa de uma série de outras. E ainda, ao falar de relações de interdependência, falamos também de tensões. Essas tensões na teia de relações adquirem uma cor local e muitas vezes, são elas as que permitem perceber a existência de certos códigos de comportamento existentes nesse mundo social em particular.

Através de uma perspectiva relacional tentei mostrar a complexidade da vida nos acampamentos e a heterogeneidade de grupos existentes: andorinhas, moradores, apoios, acampados, militantes, militantes dos acampamentos, dirigentes, velhos acampados, novos e novatos; grupos de diferenciação e de status que vivenciam e significam de maneira diferenciada seu tempo de acampamento.

Vimos a importância dos velhos acampados na regulação de conflitos e na reprodução da "forma acampamento", e dos novatos, para a continuidade dos acampamentos.

Não necessariamente os acampados se consideram e são considerados como membros dos movimentos. Estudiosos da ação coletiva ou especialistas em movimentos sociais frequentemente assumem que todos os grupos ou indivíduos mobilizados fazem parte dos quadros dos movimentos. Beletti et al. mencionam, por exemplo, fazendo referência ao MST, que

Hoje em dia, o movimento tem aproximadamente dois milhões de membros [...] que estão assentados em assentamentos da reforma 
agrária criados pelo governo, ou morando em "acampamentos" temporários, esperando uma resolução final às suas reivindicações por terra. (2008, p.294, tradução minha $)^{7}$

Já Feix (2001), no seu estudo sobre assentamentos rurais na região de Rondonópolis (MT), analisa o que ele chama de projetos sociopolíticos que levaram os trabalhadores a "ingressar" no MST. $\mathrm{O}$ autor identifica diferenças entre a base assentada e os militantes do movimento, ou o que ele chama de "defasagens" no projeto de vida entre um e outro grupo. No entanto, assume que os assentados "são do MST" e toma o momento da participação dos assentados na primeira ocupação de terra como o momento de "ingresso" ao movimento.

Segundo Sigaud, "a ideia de que os participantes de um acampamento organizado, por exemplo, pelo MST “são” do MST é uma dessas pré-noções que concebe os acampamentos a partir do modelo do clube, como se para neles ingressar fosse necessário ser sócio" (2000, p.84). Como tentei mostrar, no caso dos acampamentos de sem-terra existe uma grande circulação de indivíduos entre acampamentos organizados por diferentes movimentos. A maioria dos indivíduos, ao se instalarem debaixo da lona preta, não decidem fazer parte de um movimento, mas de um acampamento, o que me leva a concordar com Quirós (2006): os indivíduos não necessariamente são do movimento, estão em movimento.

As pessoas circulam entre acampamentos e entre movimentos transcendendo as fronteiras organizacionais. Sem constrangimento nenhum, um acampado sob a bandeira do MST podia pedir uma declaração como acampado do MTR para facilitar trâmites ou serviços na cidade; ou inclusive um acampado do MTR podia pedir uma vaga do MST no acampamento porque conseguiu trabalho na cidade e não pode mais ficar acampando todos os dias.

7 "Today the movement has approximately two million members [...] who are settled in government-funded land reform settlements or living in temporary 'encampments' awaiting final resolution of their claim to land." 
Por outro lado, mostrei que as pessoas muitas vezes se mobilizam, entram e saem e circulam entre acampamentos ao levarem em consideração a crença no prestigio do MST. No entanto, também como vimos, a crença no prestígio não é o motivo de escolha para todo mundo.

É nessa circulação pelo mundo das ocupações de terra que alguns acampados descobrem, na participação das tarefas dos movimentos (organização de grupos, convite de novas famílias para acampar, conseguir recursos para os acampamentos, negociar com os políticos) um trabalho, e encontram nisso um sentido de vida. É realizando esse trabalho que muitos conseguem significação social, visibilidade, prestigio, nome. Segundo Rosa:

A significação social desses indivíduos não é dada apenas pelo reconhecimento de sua importância pelas comunidades nas quais atuam, ela também é conquistada pelo contato individual com representantes do Estado que têm o poder de reconhecê-los como interlocutores e, por vezes, como uma extensão de seus domínios. (2009, p.175)

Assim, os movimentos, como reconhece esse autor são "instâncias de poder, mas, também de significação social (Ibidem, p.176). Como mencionam Beletti et al. (2008, p.295, tradução minha): "ocupações servem como fonte de novas lideranças, solidariedade do movimento e presença política". ${ }^{8}$

No entanto, no mundo das ocupações de terra, como identificado por alguns autores (Smircic, 2000; Rosa, 2009 e 2011; Beletti et al., 2008), são principalmente os jovens os que mais se identificam com os métodos e as formas de ação dos movimentos, notadamente do MST. Assim como os dirigentes dessa organização preferem formar quadros de jovens, por acreditarem que têm uma maior liberdade de ação.

8 "occupations serve as sources of new leadership, movement solidarity and political presence." 
Os acampados com tempo de acampamento, ou seja, com experiência na arte de ocupar, de negociar, de levar novas pessoas para os acampamentos, ajudam a entreter a espiral das ocupações de terra, podem se destacar dentre o resto dos acampados e podem ser vistos por militantes dos movimentos como apoios ou como um modelo de acampado, mas não necessariamente como parte dos quadros do movimento.

E finalmente, tentando concluir com algumas considerações de cunho metodológico, gostaria de mencionar que no mundo das ocupações de terra, assim como em qualquer outro mundo social, as pessoas vivenciam sua experiência no mundo de maneira integrada, as distintas dimensões da vida estão entrelaçadas e é o pesquisador que num esforço por compreender essas dimensões as fragmenta. Nesse sentido, me parece que a etnografia nos permite levar a sério as categorias nativas como instrumento de análise, pois fica claro que as categorias analíticas de que dispomos muitas vezes parecem limitadas para descrever a dinâmica da vida social.

Apenas para exemplificar, retomo aqui o termo correrias. Eu poderia ter qualificado as relações e os recursos que são mobilizados entre as lideranças dos movimentos e as autoridades locais ou governamentais como clientelistas ou políticas, termos comumente usados nas análises acadêmicas de maneira pejorativa para qualificar as relações de dependência características do mundo social. No entanto, correrias, me parece, traduz precisamente o dinamismo, a vida em movimento e nos movimentos.

Por outro lado, descrever a vivência ou a experiência no mundo das ocupações de terra na forma como elas são nativamente representadas nos permite colocar em evidência em quais circunstâncias e como se dá, na expressão de Manzano (2007), "o compromisso das pessoas com o governo de si mesmas."

As descobertas da pesquisa só se tornaram possíveis graças a um acúmulo de conhecimento sobre o mundo das ocupações de terra adquirido durante sucessivas incursões ao campo e a observação e registro dos dados em diferentes espaços e períodos de tempo. 
Paradoxalmente, seguir o percurso de um caso em particular, o de uma família de acampados pelo mundo das ocupações de terra, me permitiu ter uma perspectiva mais ampla desse mundo social ao ter acesso em vários momentos, a diferentes acampamentos, diferentes pessoas em trânsito, entrando e saindo desses espaços, realizando trocas, fazendo bicos, conseguindo recursos, fazendo as correrias, em suma, cumprindo seu tempo de acampamento.

Nesse sentido, acredito ter contribuído, ainda que de maneira modesta, ao desafio de Sigaud, quanto à necessidade de se verificar, a partir de investigação sistemática e comparativa, as condições sociais nas quais se produzem as entradas em acampamentos e os sentidos que os trabalhadores atribuem a este ato (2000, p.75).

Mas, afinal como tornar um dado empírico bruto em um dado sociologicamente relevante? Ou ainda, fazendo eco às preocupações de Small (2009), como fazer com que estimativas empíricas sejam relevantes ou possam iluminar outros casos?

Tendo então essa premissa como pano de fundo só me resta me posicionar, retomando os termos de Peirano (1992) "a favor da etnografia”. Para essa autora:

O lugar da pesquisa de campo no fazer da antropologia não se limita a uma técnica de coleta de dados, mas é um procedimento com implicações teóricas específicas. Se é verdade que técnica e teoria não podem ser desvinculadas, no caso da antropologia a pesquisa etnográfica é o meio pelo qual a teoria antropológica se desenvolve e se sofistica, quando desafia os conceitos estabelecidos pelo confronto que se dá entre i) a teoria e o senso comum que o pesquisador leva para o campo e ii) a observação entre os nativos. (1992, p.11)

Inspirada em Peirce, para Borges:

a lógica da pesquisa etnográfica estaria enraizada não em receitas prévias advindas do "além" da teoria, mas sim na realidade do trabalho de campo, na premência da realidade nativa, que [...] é, 
acima de tudo, eventual. O modelo triádico que perpassa boa parte da obra de Peirce vem reiterar essa premissa e nos ajudar a pensar no equilíbrio e na inseparabilidade entre etnógrafo/objeto/teoria antropológica. Cada uma dessas "partes" só existe e se afirma na medida em que as demais também se impõem. Na verdade, não se trata propriamente de partes, mas de um "tríptico" chamado etnografia. (2003, p.177) 


\section{APÊNDICE}

\section{Interlocutores}

Afonso - Juntamente com Cláudio, um sindicalista da região vinculado ao Sintraf, organizou um acampamento na Fazenda Cafeeira, nas proximidades da cidade de Castilho, onde mora com sua família. Foi o dirigente que Alfredo encontrou em Castilho e que o convidou para acampar novamente, em um acampamento do MST do qual ele era coordenador.

Ângela - Acampada novata do Terra Sem Males. Antes de ir para o acampamento em janeiro de 2003, ela morava em Polvilho, cidade vizinha ao acampamento no município de Cajamar (SP). Trabalhava catando papelão na cidade e havia sido convidada em trabalho de base por outros acampados do TSM.

Antônio - Chegou como novato no Terra Sem Males (TSM), em meados de 2002. Foi convidado por Zé Antônio durante o trabalho de base que havia feito em Limeira. Antônio demorou alguns meses para aceitar o convite, mas, quando viu que outros vizinhos e conhecidos se entusiasmaram com a ideia de ganhar terra, também se animou. Quando o TSM mudou da região de Bragança Paulista para Franco da Rocha, ele foi junto e, em Franco da Rocha, fazia a tarefa de vigia do acampamento. Mudou com algumas famílias 
do TSM para a região de Birigui, onde participou de uma saga de ocupações e da formação do acampamento Dom Hélder. Desistiu do acampamento no contexto da briga entre acampados e coordenadores do acampamento.

Betinho - É assentado no assentamento Macali. Morava em Araçatuba com seu filho e sua esposa, quando assistiram na TV local a uma matéria sobre os acampamentos da região. No bairro onde morava, foi feito um trabalho de base e ele decidiu ir acampar. Acampou pouco menos de dois anos no Dom Hélder Câmara. No final de 2005, foi assentado na Macali e foi nomeado representante dos assentados dando continuidade à tarefa de coordenação que vinha desempenhando no acampamento. Em 2007, na última contenda eleitoral no município onde se localiza o assentamento, foi candidato a vereador, mas perdeu.

Beto - Tem 62 anos. Nasceu em Natal (RN). Foi criado na roça com mais treze irmãos. Quando seus pais se separaram, ele, com 14 anos, foi para Goiás, onde morou na casa de sua irmã e ajudava seu cunhado na roça. Beto casou-se muito novo e teve um casal de filhos. Separou-se faz vários anos, deixando seu filho com uma família de conhecidos em Marília (SP), que ofereceram ajudá-lo com seus estudos. Sua filha ficou em São Paulo com sua ex-mulher. Trabalhou em vários lugares do estado de São Paulo, fazendo diversos serviços, desde porteiro, guarda de rua, até caseiro em um sítio. No final de 2001, foi convidado por um conhecido de Sarapuí (SP), que estava acampando, para participar do acampamento. Somente meses depois, em abril de 2002, animou-se a acampar e entrou no mundo das ocupações de terra, ao participar da ocupação que deu vida ao Terra Sem Males.

Biro - 40 anos. Coordenador do MST do acampamento Famílias Unidas e militante do MST. Envolveu-se na militância do movimento pouco tempo depois da sua primeira ocupação realizada na Fazenda onde foi montado o acampamento Famílias Unidas, em dezembro de 2003. Hoje em dia sua esposa participa da coordenação do Frente de massificação do MST e sua filha estuda na escola 
do MST em Goiás. Em 2008 ele e sua família foram indicados para serem assentados na Fazenda cafeeira.

Cida - Esposa de Betinho. Ela foi acampar em finais de 2003, com seu marido e seu filho, no acampamento Dom Hélder Câmara, alguns meses depois de as famílias do TSM terem montado o acampamento. Cida, junto com seu marido, rapidamente se destacou dentre os acampados pelos contatos que tinha na cidade e pela facilidade para conseguir recursos. Foi uma das que assumiram a coordenação do Dom Hélder num período em que o acampamento ficou sem militantes. Cida, com seu marido, ficou durante dois anos na coordenação do assentamento Macali.

Cido - Tem 22 anos. É militante do MST, membro da Coordenação Nacional desse movimento. Ele e sua família são originários do Paraná. Desde finais dos anos 1990, passaram por vários acampamentos do MST no Paraná, convidados por um tio que já era assentado. Com 16 anos, começou a participar da militância do movimento. Estavam acampando na região do Pontal (SP), quando lhes foi oferecida uma vaga para serem assentados. Cido já fez vários cursos de formação no movimento e em 2009 cursava a Faculdade de Filosofia na UFRJ graças a um convênio que o MST tem com essa universidade.

Cláudio-Dirigente do Sintraf ligado a CUT. Foi ele quem convidou a família Reis-Cerqueira e mais 12 famílias do acampamento Dom Hélder, para que fossem acampar na Fazenda Cafeeira. Tornou-se o coordenador do acampamento. Ele foi uma das lideranças que participaram na organização da primeira ocupação do acampamento Famílias Unidas, em dezembro de 2003, e que saiu do comando do acampamento quando o MST apoiou um grupo de acampados que não queriam acampar mais sob a bandeira do Sintraf.

Darlene - Estava acampando com sua filha no Terra Sem Males, onde também realizava atividades de militância no MST; nesse tempo fez alguns cursos de formação do movimento. Em 2003 ela foi enviada pela estadual do MST para coordenar o acampamento Dom Hélder Câmara. Foi-lhe encomendada a tarefa, juntamente com Mário, companheiro dela e militante do movimento, de 
criar uma Secretaria Regional. Ambos foram acusados pelos próprios acampados de realizarem uma má coordenação. Militantes do MST, a pedido dos acampados, os tiraram da coordenação do acampamento.

Dércio-Acampado no acampamento Famílias Unidas pelo MTR. É originário de Três Lagoas (MS), cidade onde trabalhava exercendo sua profissão de padeiro e confeiteiro. Por problemas cardíacos, teve que se aposentar. Meses depois começou uma peregrinação por vários acampamentos em Mato Grosso do Sul e decidiu cruzar para São Paulo, pois acredita que os acampamentos nesse estado são mantidos em melhores condições do que em MS. Fez uma longa viagem, de bicicleta, de acampamento em acampamento, procurando um que fosse do seu agrado. Era casado com uma moça da idade dele, mas separou-se e no acampamento Famílias Unidas conheceu sua atual esposa, uma mulher quinze anos mais velha do que ele e que já tinha duas meninas, de 11 e 13 anos. Ele acampava sob a bandeira do MST, mas no último racha do acampamento ele passou a acampar sob a bandeira do MTR.

Dona Cida - Era a coordenadora do assentamento Sumaré II (SP). Ela estava estudando para ser freira, quando começou a participar no começo dos anos 1980, na CPT, das reuniões da terra, nos primórdios das ocupações de terra no estado de São Paulo. Foi nessa "luta" que conheceu seu marido, que era seminarista. Ambos se envolveram no processo de formação dos acampamentos Sumaré I e II e foram assentados nesse último. Aos 47 anos de idade, em 27 de junho de 2003, dona Cida faleceu de um derrame, enquanto participava de um cursinho que havia ajudado a organizar para os jovens do assentamento.

Donizete - É originário de Mato Grosso do Sul. Tem 53 anos e sempre gostou de trabalhar como operador de máquinas. Nasceu e cresceu na roça. Fora os trabalhos que realizava nas fazendas, também trabalhou na empresa Codasp (Companhia de Desenvolvimento Agrário de São Paulo), fazendo serviços gerais. Depois que casou com Ilma, eles foram morar em Andradina (SP). Com 47 anos, Donizete teve um infarto, recuperou-se e continuou tra- 
balhando, um ano depois teve um segundo infarto quando operava uma máquina dentro da empresa e teve que se aposentar. Em 2004, foi acampar representando seu genro, enquanto este trabalhava.

Geni - Ela é originária do Paraná. Casou-se com Zé Antônio aos 15 anos de idade e migrou com seu marido para Campinas, em busca de trabalho. Desse casamento nasceram três filhas. Geni e o marido moraram em vários municípios do estado. Ela estava morando com sua família em Limeira (SP) quando seu marido trabalhou no MST ajudando no trabalho de base que conformaria o Terra sem Males. Dedicava-se a vender cocadas e outros doces nas ruas da cidade, para ajudar no sustento da família. Em 2006 foram morar em um acampamento no sul de Minas Gerais.

Gracilda - Estava acampando com seu marido e seus dois filhos no TSM, era originária de Vitória (ES) e havia participado da sua primeira ocupação naquele estado, no ano de 1999. Ela e sua família (seu marido e três crianças), juntamente com um grupo de acampados, haviam sido enviados por militantes do MST de uma das regionais do estado do Espírito Santo, para se juntarem a outro grupo que apoiaria uma ocupação no estado de São Paulo. Como ela e sua família já tinham bastante tempo de acampamento, a militância do MST havia prometido que logo seriam assentados, assim que surgisse uma vaga em um assentamento. Em 2003 ela e sua família foram assentadas.

Gugu - Militante do MST, membro da Coordenação Estadual do MST-SP. Ele foi encarregado de acompanhar a mobilização das famílias do TSM na saga de ocupações realizadas na região de Araçatuba em meados de 2003.

Helena - Mantinha barraco no acampamento Famílias Unidas sob a bandeira do MST. É originária de Castilho. Ela morava e trabalhava na cidade como lavadeira. Só ficava no acampamento três dias por semana, em compensação participava da maioria das mobilizações organizadas pelo MST na região. Nos dias que não ficava no acampamento, além de trabalhar, cuidava dos seus netos. Ilma - Nasceu em 1948 em Aparecida do Taboado (MS), onde morou e trabalhou fazendo serviço de roça em uma fazenda. Com 
26 anos, já tinha três filhos. Ela ficou viúva muito nova depois que seu marido teve um acidente com o trator. Vive com seu atual marido, Donizete. Foram morar em Andradina depois que casaram, e ela trabalhou num frigorífico. Em 2005 participou pela primeira vez no acampamento Famílias Unidas. Ela e o marido estavam guardando a vaga para o genro deles que trabalhava durante a semana e só passava no acampamento os finais de semana.

João - 44 anos. É originário de Santos (SP). Morou em vários lugares do estado, fazendo diversos serviços como pedreiro e operador de caminhão basculante e realizando outros bicos. Foi casado e separou-se, deixando uma filha, que não vê desde a separação. Desde finais dos anos 1990, começou a acampar em acampamentos de sem-terra no estado. O primeiro acampamento foi o Nova Esperança, em São José dos Campos, depois foi para Santa Rita, onde ficou um ano, depois mudou para um acampamento em Pagador de Andrade, em Jacareí, onde conheceu Roberta, sua atual esposa. No final de 2005, foi assentado na Fazenda Macali.

Joaquim - Tem 62 anos, é aposentado e se considera pescador de profissão. É originário da região de Três Lagoas (MS) e passou a sua vida inteira morando na beira do rio. Faz mais de quarenta anos que é casado com Luzia. Ele e a esposa moravam numa reserva dentro de uma fazenda perto da cidade de Castilho. Três anos atrás, quando foi feita uma reocupação na fazenda onde se encontra o acampamento Famílias Unidas, decidiram acampar. O desejo dele era ter o pedaço de terra perto da sua região de origem, próximo do rio. Acampava sob a bandeira do MST, pois pensava que é um movimento que tem mais força; além disso, não se incomodava com as regras do acampamento e com a exigência de cumprir com jornadas.

Jonas - Novato do acampamento Famílias Unidas, era considerado pelos moradores como apoio. Acompanha o coordenador do MST do acampamento em todas as reuniões e apoia nas tarefas do movimento. Inclusive pôs seu carro à disposição da coordenação do acampamento, para levar os militantes e acampados para as diversas atividades do movimento. 
Laís - Militante do MST da Regional de Campinas. Ela estava com pouco menos de 30 anos quando participou da fundação do acampamento Terra Sem Males. Foi uma das que organizaram a mobilização que levou cinquenta famílias do TSM para ocuparem uma serie de fazendas na região de Araçatuba.

Leo - Moradora do acampamento Famílias Unidas desde 2007, no grupo do MTR. Ela decidiu acampar depois que seu filho caçula foi para o acampamento. Leo morava em Andradina, com seu marido, seu Maia. Depois que ele teve um derrame e parou de trabalhar, ela decidiu que era o momento de acampar. Leo ficou acampada durante vários meses em outro acampamento da região, na Fazenda Brinco de Ouro, esperando surgir uma vaga no acampamento Famílias Unidas. Reproduziu um pequeno sítio no próprio barraco, com uma casa principal, uma área com criação, animais de estimação, árvores frutíferas, mudas de várias espécies de plantas e uma pequena horta.

Lúcia - Em 2009 tinha 58 anos. Acampava com seu marido, Joaquim, e seu filho caçula no acampamento Famílias Unidas. Sua filha Teresa e seus dois netos também acampavam e eram vizinhos de barraco. Teresa se considerava dona de casa, mas também, tal como seu marido, gostava da pesca.

Luiz - Militante do MST. Foi ele quem indicou a família Reis para serem assentados na Fazenda Macali. Luiz também acompanhou o processo de assentamento das famílias do Dom Hélder Câmara na mesma fazenda.

Luzia - É assentada no assentamento Macali, desde finais de 2005. Ela é originária do Espírito Santo, onde cursou até a quarta série. Anos mais tarde migrou para a região de Campinas; quando casou, comprou uma casa em um bairro de Viracopos, ainda na região de Campinas. Casou com Noé em 1989 e tem dois filhos. Trabalhava como doméstica na cidade, quando seu marido decidiu que ia acampar. Ele se juntou ao acampamento Terra Sem Males, mas ficou pouco tempo. Quase um ano e meio depois, a família toda decidiu que acamparia depois de ouvirem um carro de som que passou pelo seu bairro em Campinas anunciando as reuniões da terra. 
Eles, juntamente com sua família, ficaram mais de dois anos acampados no Dom Hélder Câmara e no final de 2005 foram assentados. Maranhão - Foi acampar em 2005 com sua esposa e cinco filhos no acampamento Famílias Unidas. Maranhão ficou acampado no grupo do MTR. Ele costumava fazer alguns bicos no acampamento, muitas vezes montando barracos, ou realizando outros trabalhos eventuais na cidade e nas fazendas próximas, para conseguir sobreviver no acampamento. Sua esposa é costureira e tinha montado um pequeno ateliê de costura no seu barraco.

Maria - É esposa de Nino e junto com ele coordenava o grupo de acampados do MTR do acampamento Famílias Unidas. Em 2009 tinha 26 anos. Originária de Castilho (SP), seu pai era fiscal e sua mãe dona de casa. É a quarta de uma família de cinco irmãs. A mais velha é assentada na Fazenda Santa Amália, foi através dela que Maria conheceu os sem-terra e aprendeu a arte da negociação e da coordenação de acampamento, já que sua irmã, tal como ela, levava o controle do caderno de pontos antes de ser assentada. Maria terminou a sétima série, mas parou de estudar para poder continuar trabalhando. Em Castilho, trabalhava para a prefeitura como varredora de rua e depois trabalhou na rodoviária da cidade fazendo serviços gerais. Pouco tempo depois de ter conhecido Nino foram acampar no acampamento Famílias Unidas em abril de 2004, onde fundaram o MTR.

Mário - Militante do MST. Em 2003, foi coordenador do acampamento Dom Hélder Câmara com Darlene, que recentemente tinha se tornado sua companheira. Juntamente com ela, montou uma Secretaria do MST, mas meses mais tarde seria acusado pelos acampados de má coordenação e de práticas de violência contra os acampados. Em 2004, deixou a coordenação do acampamento.

Mineirinho - Com mais de 60 anos, já havia passado por outros acampamentos do estado. Em 2002 participou da primeira ocupação do Terra Sem Males e um ano depois mudou, junto com outras famílias, desse acampamento para o município de Birigui, onde participou da conformação do acampamento Dom Hélder Câmara. Em 2005, foi assentado na Fazenda Macali, onde, por estar ca- 
dastrado como homem solteiro, ganhou um lote de 2,5 hectares, o chamado pararrural, metade do tamanho do lote contemplado para uma família.

Neguinho - Acampado do acampamento Famílias Unidas. Em meados de 2008, foi escolhido por outros acampados - que "racharam" com o coordenador do MST do acampamento - para que representasse o novo grupo. Eles escolheram mudar a bandeira do MST pela do Sintraf. Neguinho é filho de posseiros da Fazenda Primavera, a primeira fazenda desapropriada no estado, nos anos 1980, como decorrência de uma ocupação de terras organizada com a ajuda principalmente de membros da Igreja católica ligados à CPT.

Neusinha - Mantinha barraco no acampamento Famílias Unidas, onde passava alguns dias da semana cumprindo regra. Ela mantinha barraco sob a bandeira do MST e participava ativamente das jornadas organizadas por esse movimento. Em meados de 2008, passou a acampar sob a bandeira do Sintraf, com o grupo do $\mathrm{Ne}$ guinho. Chegou a ser a "tesoureira do Neguinho", encarregada de recolher de cada acampado a taxa de 4,50 reais por mês, que repassavam ao sindicato.

Nino - Coordenador do acampamento Famílias Unidas e fundador do MTR. É originário de Ilha Comprida (MS). Tem dez irmãos. Ainda criança mudou-se com sua família para Castilho (SP), onde estudou até a quarta série. Em Castilho ele sempre trabalhou com gado, "puxando boiada". Com 20 anos casou-se, em 1991 surgiu a oportunidade de acampar na fazenda Timboré, localizada na região, e na Timboré ele trabalhou "tocando roça". Nesse mesmo ano se separou da sua primeira mulher; quando ele estava com 25 anos casou novamente com uma pessoa que havia conhecido na Timboré. Com ela teve também dois filhos. Na Timboré ele foi coordenador de acampados e aprendeu com "os velhos" [de reforma] a negociar e fazer relações. Também nessa época fez curso técnico de inseminação de gado. Em 2001 se separou novamente e saiu da Timboré. Em 2003 voltou para morar em Castilho junto da sua família e conheceu Maria. Em abril de 2004, foi acampar na fazenda 
onde liderou um grupo de famílias sob a bandeira do OLPT e, em 2005, fundou seu próprio movimento, o MTR.

Noé - Tem 48 anos. Foi acampar em 2003, no TSM, onde ficou menos de um mês, desistiu e voltou para Viracopos, na região de Campinas, onde morava com sua mulher, Luzia, e seus dois filhos. Meses depois, novamente se animou a acampar, e ele e sua família se deslocaram até a região de Araçatuba, onde participaram de várias ocupações e da conformação do acampamento Dom Hélder Câmara, onde ficaram acampados quase dois anos. Desde final de 2005, é assentado no assentamento Macali. É dos poucos que não ficou com dívidas depois de tantos anos de acampamento, pois havia economizado o dinheiro da venda da sua casa de Viracopos conseguindo, assim, aproveitar os recursos recebidos pelo governo para comprar algumas vacas, cercar o lote e construir sua casa.

Nora - É originária de Salvador (BA). Em 2000, veio para São Paulo tentar convencer seu marido de "sair" do MST, movimento no qual era militante. Sua cunhada é assentada no Sumaré II e foi através dela que seu marido teve contato com o movimento. Nora acabou se envolvendo também na militância do MST. Em 2006, se separou do marido e decidiu voltar para Campinas com suas duas crianças, mas continuou participando das tarefas do movimento no escritório da Regional do MST. Meses depois também se afastou do movimento.

Raleigh - Novata e apoio do acampamento Famílias Unidas. Morava em Andradina com seu marido e cumpria regra de dois dias no acampamento. Em compensação, pelo tempo que não ficava no acampamento, cumpria com a participação em jornadas. Em janeiro de 2009, ela passou a ir mais seguidamente ao acampamento, pois estava arrumando seu barraco, já que seu marido havia perdido o emprego e ia ficar acampando.

Roberta - 44 anos. É originária de Fortaleza (CE). Estudou até o segundo ano do ensino médio e o último trabalho que teve foi como recepcionista. Ela, juntamente com o irmão, veio para trabalhar em São Paulo. Meses mais tarde se tornaria mãe solteira. Não tendo onde morar e como se sustentar, acabou dando seu filho para que 
um casal de conhecidos cuidasse dele. Nesse contexto de perda e depressão, teve a possibilidade de ir para um acampamento no município de Jacareí (SP). Foi ali que conheceu João, seu atual marido. Peregrinaram por vários acampamentos do estado, inclusive pelo acampamento Dom Hélder Câmara e, finalmente, no final de 2005 foram assentados na Fazenda Macali.

Roger - É originário de Salvador (BA). Ele participava ativamente na militância do MST. Conheceu o movimento através de uma irmã assentada. Em 2002, assumiu a coordenação do acampamento Terra Sem Males, onde ficou nesse cargo durante dois anos, de maneira intermitente, pois passava alguns meses fora do acampamento fazendo um curso de formação do MST. Era casado com Nora, que também era militante. Em 2004, trabalharam juntos para criar outra Secretaria Regional. Em 2005, insatisfeito com a forma de atuação de alguns militantes da região, pediu afastamento do movimento. Em 2006, separou-se de Nora e deixou o movimento.

Rose - Em 2002, ajudou a organizar a ocupação do acampamento Terra Sem Males. Rose é formada em ciências sociais e estava cursando o mestrado em ciência política quando foi convidada para formar parte dos quadros do MST. Atualmente é membro da Direção Nacional do MST.

Teresa - Tem 36 anos, é originária de Castilho, cidade onde morava antes de acampar. Era casada, mas o marido bebia bastante e para ela foi ficando difícil criar seus filhos sozinha. Foi então que, quando abriu uma vaga numa fazenda, por ocasião de uma reocupação, no dia 8 de novembro de 2007 decidiu ir e se juntar aos pais, seu Joaquim e Lúcia, que já estavam nesse acampamento fazia mais de três anos. Ela acampava no grupo do MST do acampamento Famílias Unidas, mas pouco tempo atrás mudou para o grupo do Sintraf, comandado por Neguinho. Teresa ficou como responsável pelo caderno de pontos de Neguinho.

Zé Antônio - Originário de Cianorte (PR). Desde muito cedo trabalhou na roça. Casou-se muito novo com Geni e migrou para a região de Campinas em busca de trabalho. Trabalhou em vários lugares, realizando serviço de roça e como caseiro. Nos anos 1990, já 
participava de sindicatos de trabalhadores rurais na região de Araraquara e Ribeirão Preto. Ele entrou no mundo das ocupações de terra convidado por militantes do MST que conheceu no Sindicato dos Trabalhadores Rurais de Limeira (SP). Em 2003 Zé Antônio era um dos mais ativos nas tarefas de organização e coordenação da secretaria do acampamento Terra Sem Males. Era considerado pelos acampados do TSM como uns dos mais velhos de acampamento e como apoio da militância do MST.

Zefa e Zé - Casal de assentados da Fazenda Macali. São originários de Andradina, onde moravam quando surgiu a possibilidade de acampar no Dom Hélder Câmara, no município de Birigui (SP). Eles deixaram sua casa fechada e foram acampar, para tentar cumprir seu desejo de ter um lote de terra. Ficaram três anos acampando. Tinham três filhos, dois deles morreram tragicamente em 2007. Sua filha também ganhou um lote de terra no assentamento, onde atualmente mora com seu marido.

Zélia - Velha de acampamento. Estava acampada com seu marido, Cido, e duas crianças, uma filha de 11 anos e o filho de 6, que chegou com pouco mais de 1 ano ao acampamento. Zélia era moradora do acampamento Famílias Unidas e acampava sob a bandeira do MTR. Ela é originária da região e antes de acampar morava em um sítio com sua mãe. Zélia e sua família eram consideradas pelo coordenador do acampamento do MTR como boas pessoas, moram no acampamento e não davam problema; no entanto, para o coordenador do MST, pertenceriam à categoria de acampados mortos, pois não participavam das mobilizações. 
Anexos 


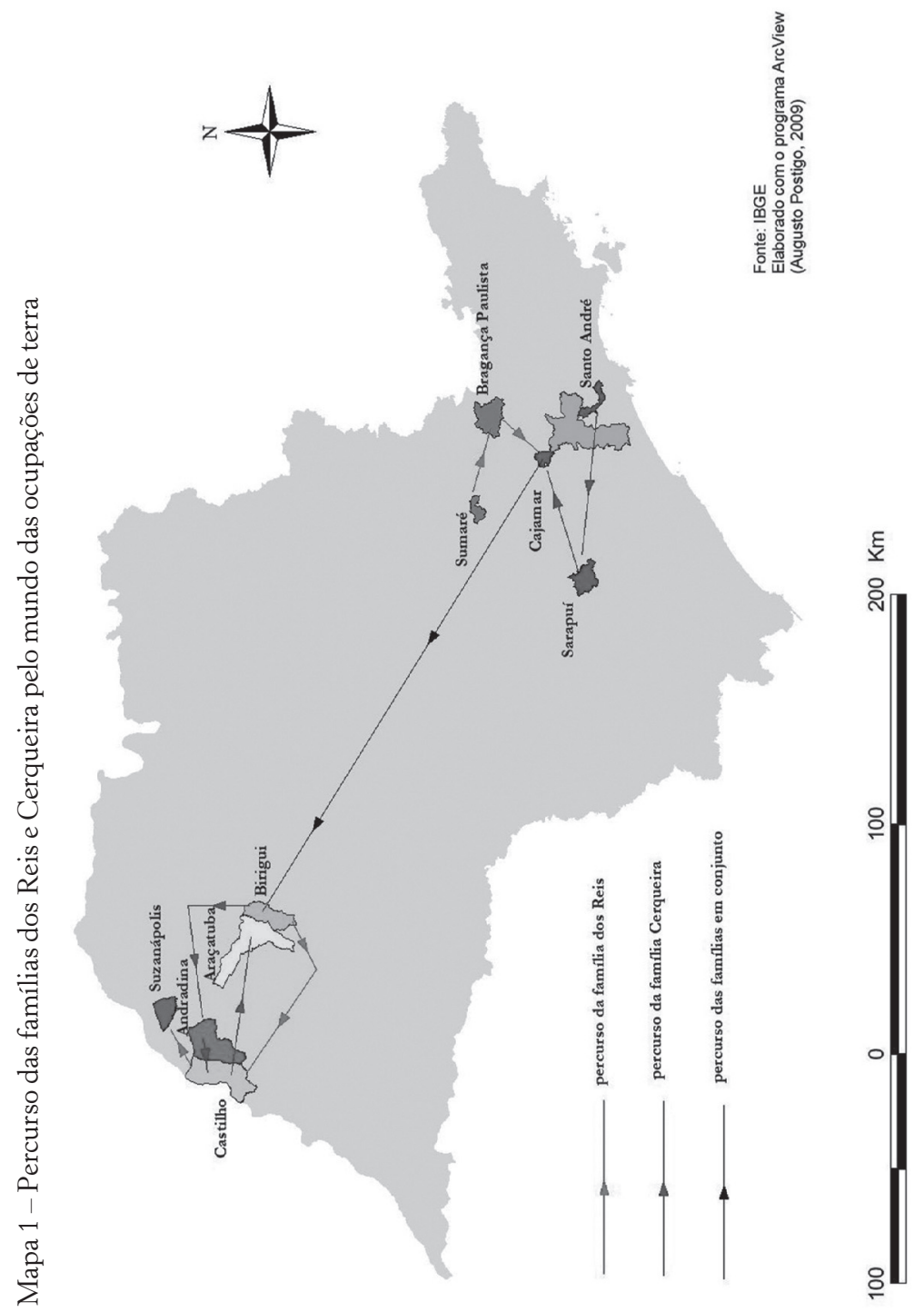




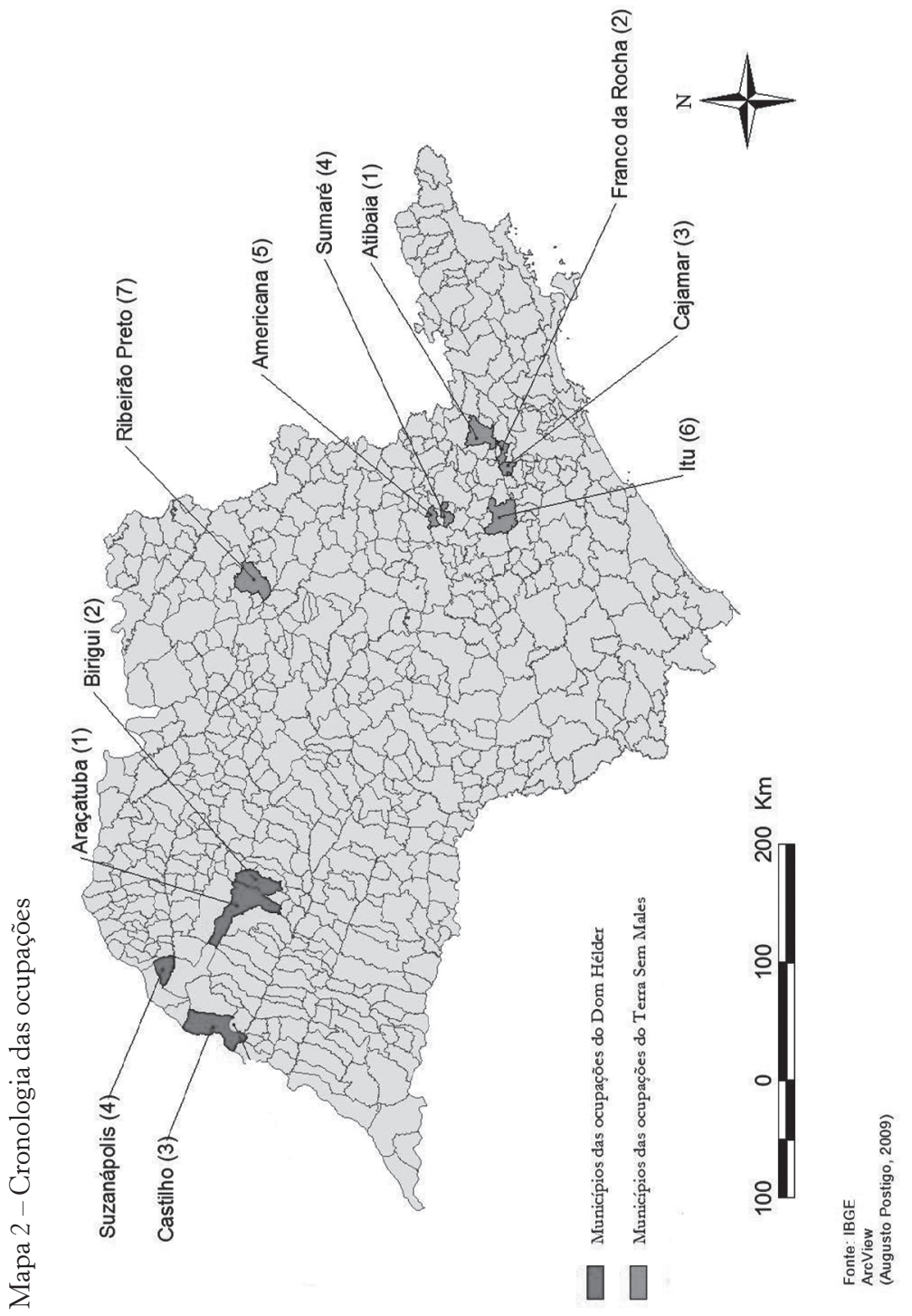




\section{Documento 1 - Informativo de campanha eleitoral}

\section{Nova Atitude na Eơucação}

*Valorizar os professores.

* Isonomia salarial baseado no valor hora-aula.

* Plano de carreira do servidor da educação. (Revisão da Lei Complementarno. 15).

*Revisar a situação, contratar mais professores adjuntos e melhorar os salários.

*O diretor do Departamento de Educação será escolhido pelos servidores da educação, professores e Conselho de Escolas.

*Verba da educação destinada somente para a educação.

*Dotar as escolas de todos os recursos materiais, tais como: material didático pedagógico, de escritório, de limpeza e uniformes logo no inicio do ano letivo.

*Adequar um sistema apostilado de ensino de acordo com a realidade local.

*Implantação de oficinas pedagógicas como elemento de apoio aos professores.

*Contratação de especialistas para suporte a educação, tais como, Assistente Social, Psicólogo, Terapeuta Ocupacional, Fonoaudiólogo nas escolas.

*Volta da prática da Educação Física nas EMEIS.

*Revisão do calendário escolar das Creches.

*Auxilio-transporte para professores da zona rural.

*Melhorar o transporte escolar.

* Criar centros de informática em cada bairro.

* Programas como PETI, AGENTE JOVEM, MEU 19 EMPREGO, etc.

\section{Nova Atitude no Sociaí}

* Os projetos scciais já existentes seräo desenvolvidos com malor qualidade e terão continuidade e até mesmo ampliados.

* Iremos articular junto às secretarias e empresas governamentais tanto federais quanto estaduais, até mesmo privadas que desenvolvem ações sociais, recursos para implantação de novos projetos sociais profissionalizantes diversificados que seräo ministrados nas áreas comerciais, prestação de serviços, artesanais, industriais e agricolas.

* Criara Casa do Artesão

* Viabilidade e participação de nossos artesãos nas exposiçães e feiras tanto internas quanto externas.

* Investiremos nas creches existentes ampliando as vagas

*Construção de novas creches.

*Faremos a manutenção da parceria e ampliação dos programa como grupo da melhor idade.

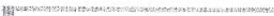

\section{Nova Atítude na Habitação}

*Aquisição de área destinada à habitação.

* Celebrar convênio com o Governo Federal para construção de casas populares.

*Casas populares a custo zero para a população.

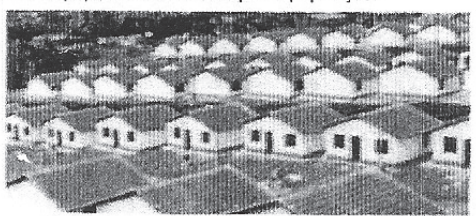

\section{Nowa Atitude na Agricultwa}

*O município de Castilho possui um grande potencial agrário, hoje nós temos em nosso município um total de 09 assentamentos, 1 reassentamento, 1 pré-assentamento, 2 acampamentos e centenas Propriedades Rurais entre Pequenas, Médias e Grandes. Por isso faremos

*Fortalecimento da Reforma Agrária no município através de projetos voltados para aumentar a renda dos assentados e pequenos produtores

* Compra de uma perfuratriz possante, que perfura ate rocha, para levar água a todos que precisam. Garantindo que nossos produtores possam irrigar suas plantações, dar água aos animais e ter água para seu sustento.

* Desenvolveremos trabalhos nos assentamentos específicos para jovens e mulheres garantindo aumento da renda familiar, através de cursos de artesanato, hortas medicinais, inseminação artificial, apicultura, entre outros. * Buscaremos parcerias com entidades públicas e privadas (SEBRAE, SENAR, EMBRAPA, SENAI, SENAC, UNESP, USP, etc.) para implantar projetos de desenvolvimento social econômico das famillias de Castilho.

*Fazermos à manutenção das estradas rurais existentes.

*Abriremos novas estradas para o escoamento da produção rural.

* Criaremos uma concessão de linha de transporte urbano, garantindo o transporte em bairros mais distantes como Primavera, Beira Rio, etc.

* Implantaremos escolas nos assentamentos

*Implantaremos áreas de lazer (centros comunitários) em todos os assentamentos

*Instalação de UBS (Unidade Básica de Saúde) nos assentamentos, com um médico, auxiliares e um dentista.

*Adequar o Departamento Agrícola contratanóo mais técnicos para ajudar os. produtores em todas as suas necessidades, criando um setor especifico a fim de desenvolver projetos, tais como: irrigação de pastagens, produção de leite, fruticultura, etc.

${ }^{*}$ Criar o Agente Rural (Técnico que ajudará os produtores rurais em suas atividades)

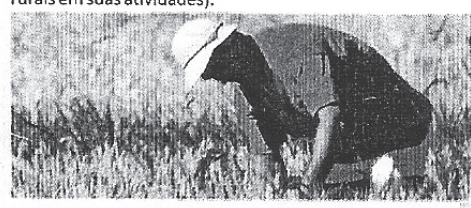

\section{Nova Atitude na Administração}

*Nosso grande desafio será fazer funcionar o Orçamento Participativo.

*O dinheiro público que a Prefeitura utiliza vem do seu bolso. Por isso é você quem tem de decidir onde e como a administração municipal deve gastá-lo. Vamos implantar o orçamento participativo e abrir espaço para que você decida junto com a Prefeitura a destinação dos recursos do orçamento municipal.

* Participação aberta a todos os cidadãos.

* Combinaçăo de democracia direta e representativa.

* A datação dos recursos para investimentos baseada na combinação de critérios gerais e técnicos respeitando as ações governamentais perante a Lei de Responsabilidade Fiscal. 
Documento 2 - Declaração de residência e filiação ao MTR

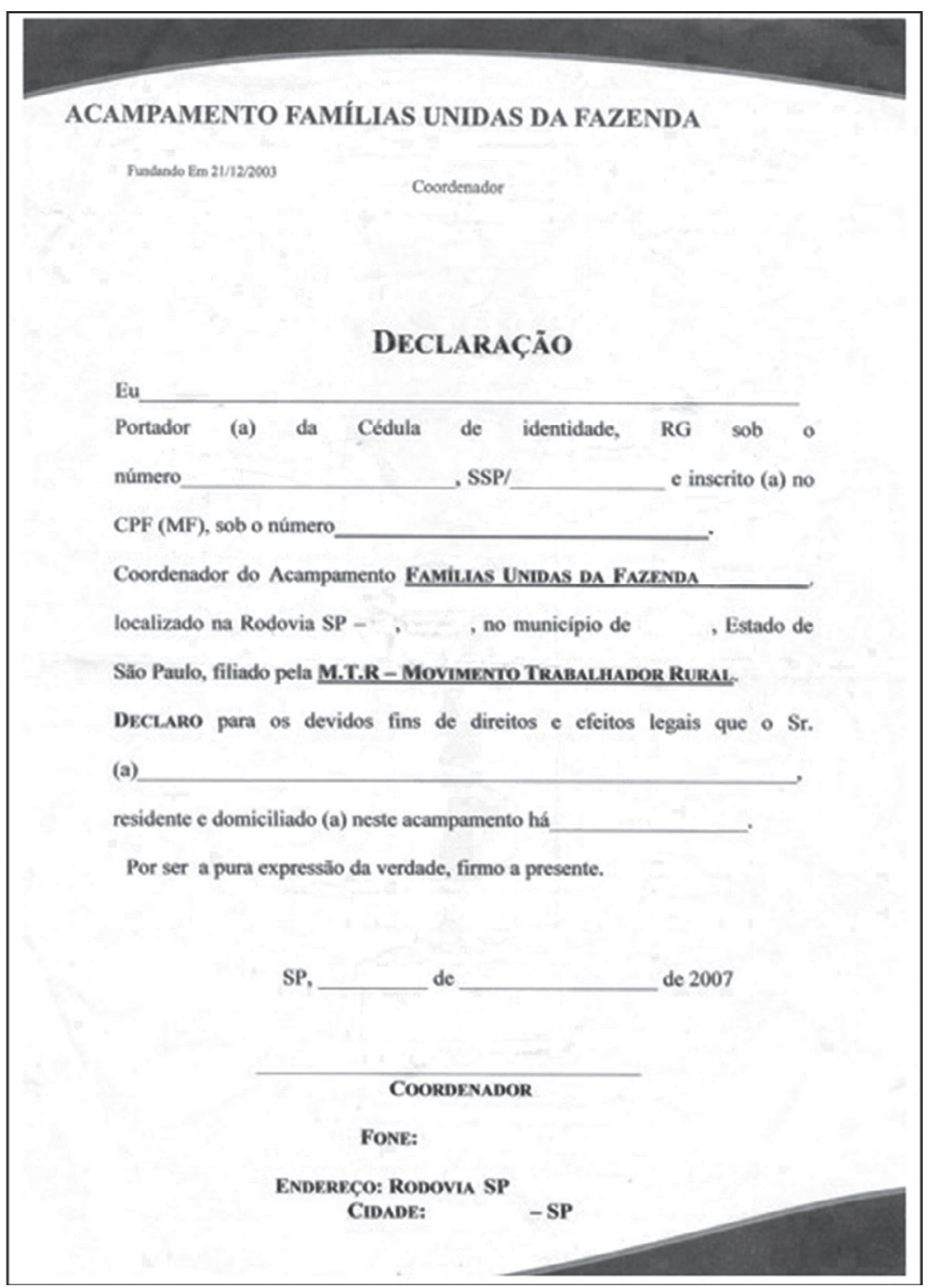




\section{REFERÊNCIAS BIBLIOGRÁFICAS}

ARENSBERG, C.; KIMBALL, S. Relações de crédito na Irlanda rural. In: DAVIS, S. (Org.). Antropologia do direito. Estudo comparativo de categorias de divida e contrato. Rio de Janeiro: Jorge Zahar, 1973, p.86100.

ANTUNIASSI, M. H. 15 anos de assentamentos de trabalhadores rurais no estado de São Paulo: o caso da família Pereira. In: BERGAMASCO, S. et al. (Orgs.). Dinâmicas familiar, produtiva e cultural nos assentamentos rurais de São Paulo. Campinas; Araraquara; São Paulo: Feagri-Unicamp; Uniara; Incra, 2003.

BALBI, F. A. Sabe o que significa a lealdade? Análise antropológica de um valor moral peronista. Rio de Janeiro, 2004. Tese (Doutorado em Antropologia Social) - Universidade Federal do Rio de Janeiro.

BALETI, B. et al. Late Mobilization: Transnational Peasant Networks and Grassroots Organizing in Brazil and South Africa. Journal of Agrarian Change, v.8, n.2-3, p.290-314, 2008.

BARRA, C. S. Mario Lago encontra Terra Sem Males: a produção do Outro em acampamentos dos sem-terra. Campinas, 2007. Dissertação (Mestrado em Antropologia Social) - Instituto de Filosofia e Ciências Humanas da Universidade de Campinas.

BERGAMASCO, S. M. P. P. O que são assentamentos rurais. São Paulo: Brasiliense, 1996.

.; NORDER, L. A. C. A alternativa dos assentamentos rurais: organização social, trabalho e política. São Paulo: Terceira Margem, 2003. 
et al. Dinâmicas familiar, produtiva e cultural nos assentamentos rurais de São Paulo. Campinas; Araraquara; São Paulo: Feagri-Unicamp; Uniara; Incra, 2003.

BERGAMO, A. A experiência do status: roupa e moda na trama social. São Paulo: Editora Unesp, 2007.

BOHANNAN, P. A categoria injô na sociedade tiv. In: DAVIS, S. (Org.). Antropologia do direito. Estudo comparativo de categorias de dívida e contrato. Rio de Janeiro: Jorge Zahar, 1973.

BOIVIN, M. F.; ROSATO, A.; BALBI, F. A. Quando o inimigo te abraça com entusiasmo...: etnografia de uma traição. Revista Mana, Rio de Janeiro, v.4, n.2, 1998. Disponível em: <http://www.scielo.br/scielo. php? script $=$ sci_arttext\&pid $=$ S0104-93131998000200002\&lng $=$ en $\&$ nrm=iso>. Acesso em: 18 set. 2007.

BORGES, A. Tempo de Brasília: etnografando lugares-eventos da política. Rio de Janeiro: Relume Dumará, 2003. (Coleção Antropologia da Política)

A fórmula do tempo: notas etnográficas sobre o "tempo de Brasília”. In: TEIXEIRA, C. C.; CHAVES, C. A. (Orgs). Espaços e tempos da política. Rio de Janeiro: Relume Dumará, 2004.

BOURDIEU, P. Ce que parler veut dire : l'économie des échanges linguistiques. Paris: Fayard, 1982.

. A economia das trocas simbólicas. São Paulo: Perspectiva, 1998.

Esquisse d'une théorie de la pratique : précédée de trois études d'ethnologie kabyle. Paris: Seuil, 2000.

. Les sens pratique. Paris: Minuit, 2002.

A produção da crença: contribuição para uma economia dos bens simbólicos. São Paulo: Zouk, 2004.

BOURGOIS, P. In Search of Respect: Selling Crack in El Barrio. Nova York: Cambridge University Press, 1995.

BRANFORD, S.; ROCHA, J. Rompendo a cerca: a história do MST. São Paulo: Casa Amarela, 2004.

BRENNEISEN, E. Assentamento Sepé Tiaraju: persistências do passado, fragmentos do presente. In: MARTINS, J. de S. (Coord.). Travessias: a vivência da reforma agrária nos assentamentos. Porto Alegre: Editora da UFRGS, 2003, p.53-106.

CAUME, D. A tessitura do "assentamento de reforma agrária": discursos e práticas instituintes de um espaço agenciado pelo poder. Campinas, 2002. Tese (Doutorado em Ciências Sociais) - Universidade Estadual de Campinas. 
CHAVES, C. de A. A marcha nacional dos sem-terra. Rio de Janeiro: Relume Dumará, 2000.

COMERFORD, J. C. Fazendo a luta: sociabilidade, falas e rituais na construção de organizações camponesas. Rio de Janeiro: Relume Dumará. 1999. (Coleção Antropologia da Política)

. Como uma família: sociabilidade, territórios de parentesco e sindicalismo rural. Rio de Janeiro: Relume Dumará, 2003. (Coleção Antropologia da Política)

CORADINI, O. L. Em nome de quem? Recursos sociais no recrutamento de elites políticas. Rio de Janeiro: Relume Dumará, 2001.

D'INCAO, M. C.; ROY, G. Nós, cidadãos: aprendendo e ensinando a democracia. São Paulo: Paz e Terra, 1995.

DUBY, G. Guillaume le marechal ou le meilleur chevalier du monde. Paris: Fayard, 2003.

ECKERT, C. Movimento dos agricultores sem-terra no Rio Grande do Sul: 1960 -1964. Seropédica, 1984. Dissertação (Mestrado) - Instituto de Ciências Humanas e Sociais, Universidade Federal Rural do Rio de Janeiro.

ELIAS, N. Mozart: sociologia de um gênio. Rio de Janeiro: Jorge Zahar, 1995.

Os alemães: a luta pelo poder e a evolução do habitus nos séculos XIX e XX. Rio de Janeiro: Jorge Zahar, 1997.

. Sobre o tempo. Rio de Janeiro: Jorge Zahar, 1998.

. La société de cour. France: Champs, Flammarion, 2005.

. Escritos e ensaios: Estado, processo, opinião pública. Rio de Janeiro: Jorge Zahar, 2006.

ELIAS, N.; SCOTSON L. J. Os estabelecidos e os outsiders. Rio de Janeiro: Jorge Zahar, 2000.

EVANS-PRITCHARD, E. E. [1940]. Os nuer. São Paulo: Editora Perspectiva, 2002.

FEIX, P. J. Os interesses sociais e a concepção política e ideológica dos trabalhadores rurais assentados do MST: estudo de caso na região de Rondonópolis (MT). Campinas, 2001. Dissertação (Mestrado em Ciência Política) - Universidade Estadual de Campinas.

FERNANDES, B. M. Gênese e desenvolvimento do MST. São Paulo: MST, 1998.

MST: formação e territorialização. São Paulo: Hucitec, 1999.

A formação do MST no Brasil. Petrópolis: Vozes, 2000. 
FERRANTE, V. B. Retratos de assentamentos. Cadernos de Pesquisa, Araraquara, ano V, n.7, Nupedor, Unesp, 1999.

GARCIA JR., Afrânio. O sul, caminho do roçado: estratégias de reprodução camponesa e transformação social. São Paulo: Marco Zero, Editora UnB, 1990.

GIARRACCA, Norma et al. Cuando el territorio es la vida: la experiencia de los sin tierra en Brasil. Buenos Aires: Antropofagia, 2006.

GLUCKMAN, Max. Obrigação e dívida. In: DAVIS, S. (Org.). Antropologia do direito: estudo comparativo de categorias de dívida e contrato. Rio de Janeiro: Jorge Zahar, 1973, p.25-56.

GRIMBERG, M.; FERNÁNDEZ, A. M. I.; ROSA, M. Estado y movimientos sociales: estudios etnográficos en Argentina y Brasil. Buenos Aires: Antropofagia, UBA, 2009.

GUARANÁ, E. de C. Juventude rural: construções, reordenações e negociações de identidades sociais. Paper apresentado na 25a Reunião Brasileira de Antropologia. Goiânia, 11-14 jun., 2006.

HAVILAND, J. B. Gossip: Reputation and Knowledge in Zinacantan. Chicago: University of Chicago Press, 1977.

JORGENSEN, D. L. The Methodology of Participant Observation. In: Participant Observation: a Methodology for Human Sciences. Newbury Park: Sage, 1989, v.15, p.12-25. (Applied Social Research Methods Series)

KERKVLIET, B. Everyday Politics in Peasant Societies (and ours). Journal of Peasant Studies, 2009, v.36, n.1, p.227-43.

LEACH, E. R. Concerning Trobriand Clans and the Kinship Category "Tabu". In: Jack Godoy (Ed.), The Developmental Cycle in Domestic Groups. London: Cambridge University Press, 1971.

Sistemas políticos da alta Birmânia. São Paulo: Edusp, 1995.

LECHAT, P. M. N.. A questão de gênero no Movimento dos Trabalhadores Rurais Sem-Terra (MST): estudo de dois assentamentos rurais no Rio Grande do Sul. Campinas, 1993. Dissertação de mestrado. Universidade Estadual de Campinas.

LEITE, S. et al. Impacto dos assentamentos: um estudo sobre o meio rural brasileiro. São Paulo: Editora Unesp; Nead, 2004.

L'ESTOÎLE, B. de; PINHEIRO, C. Projetos, apostas e hesitações: notas sobre três engenhos em situação de incerteza. In: L'ESTOÎLE, B. de; SIGAUD, L. (Orgs.). Ocupações de terra e transformações sociais. Rio de Janeiro: FGV, 2006. 
.; SIGAUD, L. (Orgs.). Ocupações de terra e transformações sociais. Rio de Janeiro: FGV, 2006.

LOERA, N. A espiral das ocupações de terra. São Paulo: Polis; Campinas: Ceres, 2006.

. Limpando os "maus elementos": disciplina e acordos num acampamento do MST. In: GRIMBERG, M.; FERNÁNDEZ, M. I.; ROSA, M. Estado y movimientos sociales: estudios etnográficos en Argentina y Brasil. Buenos Aires: Antropofagia, UBA, 2009.

Tempo de acampamento. Campinas, 2009. Tese (Doutorado em Antropologia Social) - PPGAS, Unicamp, 2009a.

. Encampment Time: an Anthropological Analysis of the Land Occupations in Brazil. Journal of Peasant Studies, April 2010, v.37, n.2.

As formas de acampamento. Projeto Jovem Pesquisador, processo n. 2010/02331 -6. Fundação de Amparo à Pesquisa do Estado de São Paulo, 2010a.

As formas de acampamento: variações de uma forma de demanda coletiva. Paper apresentado na IX Reunión de Antropología del Mercosur (RAM). Curitiba, 10 a 13 de julho de 2011 (mimeo).

Acampamentos em movimento: circulação e alianças no mundo das ocupações de terra. Paper apresentado no Simpósio Internacional Habitar o Mundo. Campinas, maio, 2013. IFCH, Unicamp (mimeo).

MACEDO, E. M. Zé Pureza: etnografia de um acampamento no norte fluminense. Rio de Janeiro, 2003. Tese (Doutorado em Ciências Sociais) -. Universidade Estadual do Rio de Janeiro.

. Entre a "violência" e a "espontaneidade": reflexões sobre os processos de mobilização para ocupações de terra no Rio de Janeiro. Revista Mana, Rio de Janeiro, v.11, n.2, p.473-97, out., 2005.

MALINOWSKI, B. Théorie ethnographique du langage. In: Les jardins de corail. Paris: La Découverte, 2002.

Crime e costume na sociedade selvagem. Brasília: UnB, 2003.

MANZANO, V. De la matanza obrera a capital nacional del piquete: etnografía de procesos políticos y cotidianos en contextos de transformación social. Buenos Aires, 2007 Tese (Doctorado) - Facultad de Filosofía y Letras, Universidad de Buenos Aires.

MARTINS, J. de S. O sujeito da reforma agrária. In: Travessias: a vivência da reforma agrária nos assentamentos. Porto Alegre: UFRGS, 2003.

Reforma agrária: o impossível diálogo. São Paulo: Edusp, 2004. 
MAUSS, M. [1923-24]. Essai sur le don : forme et raison de l'échange dans les sociétés archaïques. In : Sociologie et anthropologie. Paris: Quadrige, Presses Universitaires de France, 2003.

. [1904-05]. Essai sur les variations saisonnières des sociétés Eskimos. Étude de morphologie sociale. In: Sociologie et anthropologie. Paris: Quadrige, Presses Universitaires de France, 2003a. Sociologia e Antropologia. São Paulo: Cosac Naify, 2003b.

MEDEIROS, L. S. de. Reforma agrária no Brasil: história e atualidade da luta pela terra. São Paulo: Fundação Perseu Abramo, 2003.

MEDEIROS, L. S. de et al. Assentamentos rurais: uma visão multidisciplinar. São Paulo: Unesp, 1994.

MESZAROS, George. Taking the Land into Their Hands: the Landless Workers Movement and the Brazilian State. Journal of Law and Society, December 2000, v.27, n.4, p.517-41.

NAVARRO, Z. Mobilização sem emancipação: as lutas sociais dos sem-terra no Brasil. In: Santos B. de S. (Org.). Produzir para viver: os caminhos da produção não capitalista. Rio de Janeiro: Civilização Brasileira, 2002.

. Transforming Rights into Social Practices? The Landless Movement and Land Reform in Brazil, IDS Bulletin, v.36, n.1, p.129-42, 2005.

NORDER, L. A. Estado, sistemas de crédito e arranjos locais. In: BERGAMASCO, S. et al. (Orgs.). Dinâmicas familiar, produtiva e cultural nos assentamentos rurais de São Paulo. Campinas: Feagri-Unicamp; Araraquara: Uniara; São Paulo: Incra. 2003.

ONDETTI, G. Repression, Opportunity, and Protest: Explaining the Takeoff of Brazil's Landless Movement. Latin American Politics and Society, v.48, n.2, p.61-94, 2006.

PALMEIRA, M. Política e tempo: nota exploratória. In: PEIRANO, M. (Org.). O dito e o feito: ensaio de antropologia dos rituais. Rio de Janeiro: Relume Dumará, 2002.

PALMEIRA, M.; BARREIRA, C. Introdução. In: Política no Brasil: visões de antropólogos. Rio de Janeiro: Relume Dumará, 2006. (Coleção Antropologia da Política)

PEIRANO, M. A favor da etnografia. Brasília: UnB, 1992.

. This Horrible Time of Papers: documentos e valores nacionais, n.312. Brasília: UnB, 2002. (Série Antropologia)

PINA CABRAL, J. Mães, pais e nomes no baixo sul (Bahia, Brasil). In: ; VIEGAS, S. de M. (Org.). Nomes: género, etnicidade e família. Coimbra: Almedina, 2007. 
QUIRÓS, J. Cruzando la Sarmiento: una etnografía sobre piqueteros en la trama social del sur del Gran Buenos Aires. Buenos Aires: Ed. Buenos Aires, 2006, v.1. Antropofagia. (Serie Etnográfica)

RAPCHAN, S. E. De identidades e pessoas: um estudo de caso sobre os sem-terra de Sumaré. São Paulo, 1993. Dissertação (Mestrado) Departamento de Antropologia, Universidade de São Paulo.

ROSA, M. O sem-terra partido ao meio: um estudo de caso sobre as relações sociais entre assentados e municípios receptores na região da Grande Porto Alegre (RS). Rio de Janeiro, 2000. Dissertação (Mestrado em Desenvolvimento, Agricultura e Sociedade), Universidade Federal Rural do Rio de Janeiro.

O engenho dos movimentos: reforma agrária e significação social na zona canavieira de Pernambuco. Rio de Janeiro, 2004. Tese (Doutorado em Ciências Humanas: sociologia) - Departamento de Ciências Sociais, Instituto Universitário de Pesquisas do Rio de Janeiro.

Biografias e movimentos de luta por terra em Pernambuco. Tempo Social. Revista de Sociologia da USP, São Paulo, v.21, n.1, p.157-80, 2009.

A "forma movimento" como modelo contemporâneo de ação coletiva rural no Brasil. In: Grimberg, M.; Fernández, M. I.; (Orgs.). Estado y movimientos sociales: estudios etnográficos en Argentina y Brasil. Buenos Aires: UBA/Antropofagia, 2009a, p.53-72.

Sem-terra: sentidos e as transformações de uma categoria de ação coletiva no Brasil. Revista Lua Nova, São Paulo, n.76, 2009b.

Engenho dos movimentos: reforma agrária e significação social na zona canavieira de Pernambuco. Rio de Janeiro: Garamond, 2011.

SCHMITT, C. O tempo do acampamento: a construção da identidade social e política do "colono sem-terra". Porto Alegre, 1992. Dissertação (Mestrado em Sociologia Rural) - UFRGS.

SIGAUD, L. A forma acampamento. Revista Novos Estudos Cebrap, São Paulo, n.58, p.73-92, nov., 2000.

Ocupações de terra, Estado e movimentos sociais no Brasil. Cuadernos de Antropología Social, Universidade de Buenos Aires, n.20, p.11-23, 2004.

As condições de possibilidade das ocupações de terra. Tempo Social. Revista de Sociologia da USP, São Paulo, v.17, n.1, p.255-80, jun., 2005.

Prólogo. In: QUIRÓS, J. Cruzando la Sarmiento: una etnografía sobre piqueteros en la trama social del sur del Gran Buenos Aires. Buenos Aires: Antropofagia, 2006, p.13-9. 
Se eu soubesse: os dons, as dívidas e suas equivalências. Ruris, v.1, n.2, set., 2007.

; ROSA, M.; MACEDO, M. Ocupações de terra, acampamentos e demandas ao Estado: uma análise em perspectiva comparada. Dados. Revista de Ciências Sociais, v.51, n.1, p.107-42, 2008.

SIGAUD, Lygia et al. Lonas e bandeiras em terras pernambucanas. Rio de Janeiro: UFRJ, 2002.

SILVA, V. Experiências e representações do ser jovem em Rosário das Almas, Temáticas, Campinas: Instituto de Filosofia e Ciências Humanas da Unicamp, ano 14, n.27/28, 2006.

SIMMEL, G. Sociología I: estudios sobre las formas de socialización. Madrid: Alianza Universidad, 1977.

SMALL, M. L. How Many Cases do I Need? On Science and the Logic of Case Selection in Field-Based Research, Ethnography, v.10, n.1, p.5-38, 2009.

SMIRCIC, S. C. Com a cara e a coragem: etnografia de uma ocupação de terra em Pernambuco. Rio de Janeiro, 2000. Dissertação (Mestrado) PPGAS, Museu Nacional.

SPAROVEK, G. A qualidade dos assentamentos da reforma agrária brasileira. USP/MDA/FAO. São Paulo: Páginas \& Letras, 2003.

STÉDILE, J. P.; FERNANDES, B. M. O MST e a questão agrária. Entrevista com João Pedro Stédile, Revista Estudos Avançados, São Paulo: USP, v.11, n.31, set.-dez., 1997.

Brava gente. A trajetória do MST e a luta pela terra no Brasil. São Paulo: Fundação Perseu Abramo, 1999.

THOMPSON, E. P. The Poverty of Theory or an Orrery of Errors: in the Poverty of Theory and Other Essays. New York e London: Monthly Review Press, 1978.

VELTMEYER, H.; PETRAS, J. The Social Dynamics of Brazil's Rural Landless Workers' Movement: Ten Hypotheses on Successful Leadership, Canadian Review of Sociology, v.39 n.1, p.76-96, 2002.

VERGARA-CAMUS, L. The MST and the EZLN Struggle for Land: New Forms of Peasant Rebellions. Journal of Agrarian Change, v.9, n.3, p.365-91, 2009.

VILLARREAL, M. Deudas, drogas, fiado y prestado en las tiendas de abarrotes rurales, Ruris, v.2, n.1, p.99-128, mar., 2008.

WANDERLEY, M. de N. B,. Morar e trabalhar: o ideal camponês dos assentados de Pitanga. Estudo de caso no Nordeste. In: MARTINS, J. de S. (Org.), Travessias: a vivência da reforma agrária nos assentamentos. Porto Alegre: Editora da UFRGS, 2003, p.203-46. 
WEBER, M. Economía y sociedad. México: Fondo de Cultura Económica, 1992.

WOLFORD, W. Producing Community: the MST and Land Reform Settlements in Brazil, Journal of Agrarian Change, v.3, n.4, p.500-20, 2003.

The Difference Ethnography Can Make: Understanding Social Mobilization and Development in the Brazilian Northeast, Qualitative Sociology, v.29, n.3, p.335-52, 2006.

\section{Outras fontes}

MINISTÉRIO DO DESENVOLVIMENTO SOCIAL E COMBATE À FOME. Disponível em: <http://www.mds.gov.br/bolsafamilia/o_ programa_bolsa_familia/beneficios-e-contrapartidas $>$.

MOVIMENTO DE LUTA PELA TERRA. Disponível em: http:// www.mlt.org.br.

MOVIMENTO DOS TRABALHADORES RURAIS SEM-TERRA. Disponível em: <http://www.mst.org.br>.

MOVIMENTO NACIONAL DE PRODUTORES. Disponível em: http://www.mnp.org.br.

SENADO FEDERAL. Constituição da República Federativa do Brasil. Disponível em: <www.senado.gov.br/bdtextual/const88/ Con1988br.pdf>.

FOLHA DA REGIÃO. Disponível em: <www.folhadaregiao.com.br>. MINISTÉRIO DA PREVIDÊNCIA SOCIAL. Disponível em: <www. previdenciasocial.gov.br>. 
SOBRE O LIVRO

Formato: $14 \times 21 \mathrm{~cm}$

Mancha: $23,7 \times 42,5$ paicas

Tipologia: Horley Old Style 10,5/14

Papel: Off-set $75 \mathrm{~g} / \mathrm{m}^{2}$ (miolo)

Cartão Supremo $250 \mathrm{~g} / \mathrm{m}^{2}$ (capa)

1ạ edição: 2014

EQUIPE DE REALIZAÇÃO

Coordenação Geral

Marcos Keith Takahashi 